\title{
Organic carbon and fertility of forest soils on the Allegheny Plateau of West Virginia
}

Anthony Blaine Jenkins

West Virginia University

Follow this and additional works at: https://researchrepository.wvu.edu/etd

\section{Recommended Citation}

Jenkins, Anthony Blaine, "Organic carbon and fertility of forest soils on the Allegheny Plateau of West Virginia" (2002). Graduate Theses, Dissertations, and Problem Reports. 1525.

https://researchrepository.wvu.edu/etd/1525

This Thesis is protected by copyright and/or related rights. It has been brought to you by the The Research Repository @ WVU with permission from the rights-holder(s). You are free to use this Thesis in any way that is permitted by the copyright and related rights legislation that applies to your use. For other uses you must obtain permission from the rights-holder(s) directly, unless additional rights are indicated by a Creative Commons license in the record and/ or on the work itself. This Thesis has been accepted for inclusion in WVU Graduate Theses, Dissertations, and Problem Reports collection by an authorized administrator of The Research Repository @ WVU. For more information, please contact researchrepository@mail.wvu.edu. 


\title{
Organic Carbon and Fertility of Forest Soils on the Allegheny Plateau of West Virginia
}

Anthony Blaine Jenkins, B.S.

Thesis submitted to the Davis College of Agriculture, Forestry, and Consumer Sciences at West Virginia University in partial fulfillment of the requirements for the degree of

\author{
Master of Science \\ in \\ Plant and Soil Sciences
John Sencindiver, Ph.D., Chair
Ray Hicks, Ph.D.
Alan Sexstone, Ph.D. \\ Division of Plant and Soil Sciences
Morgantown, West Virginia 2002

Keywords:

Forest soil, soil organic carbon, vegetative biomass carbon, microbial biomass, calcium depletion, soil phosphorus, soil magnesium, aluminum saturation. 


\title{
ABSTRACT \\ ORGANIC CARBON AND FERTILITY OF FOREST SOILS ON THE ALLEGHENY PLATEAU OF WEST VIRGINIA.
}

\author{
Anthony Blaine Jenkins, B.S.
}

Soil series occurring above $1020 \mathrm{~m}$ in elevation in the Monongahela National Forest in West Virginia were sampled and analyzed for soil organic and soil microbial biomass carbon as well as various fertility parameters. Additionally, vegetative biomass estimates were made at the sampling sites. The soil series sampled (established and tentative) are frigid, well and moderately-well drained inceptisols and spodosols, covered by northern hardwood or spuce-dominated forests. The purpose of the work was to document soil organic carbon (SOC), vegetative organic carbon (VOC), and soil microbial biomass carbon (SMBC) of selected horizons, and nutrient stock ranges for these extensive series, and to look at relationships among these parameters. These series contained from 11.3 to $18.8 \mathrm{~kg} \mathrm{~m}^{-2} \mathrm{SOC}$, and from 15.9 to $29.7 \mathrm{~kg} \mathrm{~m}^{-2} \mathrm{VOC}$. The SOC was found to be significantly greater than that of previously sampled analogous mesic series. Soil microbial biomass $\mathrm{C}$ was found to comprise from 4 to 65 percent of SOC in the Oe and A or AE horizons examined, and SMBC was greater in the horizons of the northern hardwood sites than those of the spruce sites. The SMBC of the frigid series was found to be closely correlated to SOC, and to base saturation of effective cation exchange capacity (ECEC). No strong correlations were observed between VOC and other measured parameters. The total stocks of Ca for these series ranged from 497 to $1095 \mathrm{~kg} \mathrm{ha}^{-1}$. The total stocks of $\mathrm{Mg}$ ranged from 2085 to $6662 \mathrm{~kg} \mathrm{ha}^{-1}$. The total stocks of P ranged from 765 to $2524 \mathrm{~kg} \mathrm{ha}^{-1}$. The series of this study exhibit close correlations of extractable $\mathrm{Ca}$ and $\mathrm{P}$ to total stocks of these elements and to SOC within the sampled pedons. Extractable $\mathrm{Mg}$, and extractable and total stocks of $\mathrm{Ca}$ and $\mathrm{P}$ were closely correlated to SOC and ECEC. 


\section{Acknowledgements}

This study and all I have learned from it is the result of the talent, work, and wisdom of many people to whom I am indebted. My greatest appreciation is extended for the generosity of patience and knowledge I received from Dr. Sencindiver, and from the rest of the committee members; Drs. Ray Hicks, Alan Sexstone, and Stanislaw Tajchman. My respect for you has only grown during the course of our association, and grows still. I would like to single out for appreciation Drs. Stanley Buol and Earl Stone, who offered insights and examples which I am still attempting to digest.

This project would not be possible without the support and creativity of Stephen Carpenter. I owe him, Dale Childs, and Bill Hatfield a great debt for their support of my educational aspirations.

Many others assisted greatly with this work and the studies behind it, including Dr. Mary Beth Adams, Don Flegel, Dr. Jim Gorman, Dr. Robert Grossman, Deb Harms, and Roy Pyle. My thanks go out to the fine soil scientists, conservationists, and technicians who assisted in sampling, including (the above), and: James (Skip) Bell, Carlos Cole, Tim Dilliplane, Jim Doolittle, Ron Estepp, Clay Handley, Ed Hanson, Scott Hoover, Ron Howard, Dr. Phil Schoeneburger, Alex Topalanchik, Sharon Waltmann, Brooke Witsberger, Linton Wright, and more.

There are innumerable folks who made it possible for me to work into and through the years of this study. Most prominently deserving of gratitude are my parents Dorothy Jean Gunter and Leonard Garland Jenkins, Jr. They are responsible for all the good I might do, and none of the bad. I can only speculate on how fortunate I am to have had parents and grandparents of such kind and supportive nature. Thanks to the rest of you, and may your support be repaid in kind.

My awe and thanks go out to the scientists throughout time whose work transcends them and gives us opportunities and challenges and goals that now transcend us. I appreciate the opportunity to be part of something bigger than myself, and hope to continue being so-occupied. 


\section{TABLE OF CONTENTS}

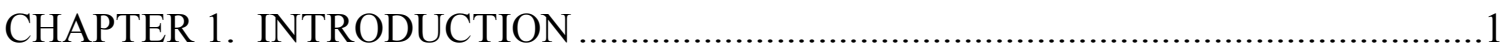

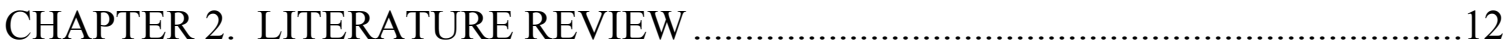

Soil Organic Carbon: Amounts and Distribution.................................................12

Soil Organic Carbon: Occurrence, Characteristics, and Importance ..................... 14

Soil Organic Carbon: Determining Factors ................................................ 17

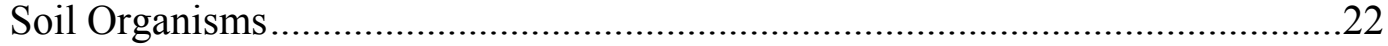

Measuring Soil Microbial Biomass Carbon.....................................................25

Soil Organic Carbon: Climate Change Effects ..................................................26

The Interrelationship of Soil Organic Carbon and Fertility ...............................27

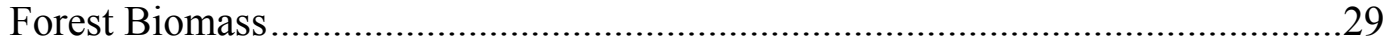

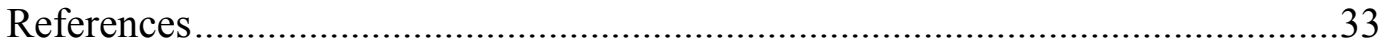

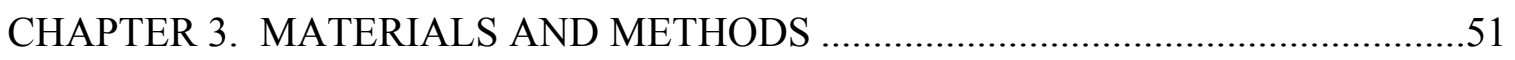

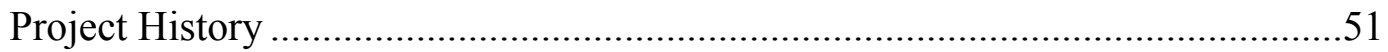

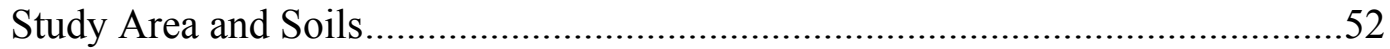

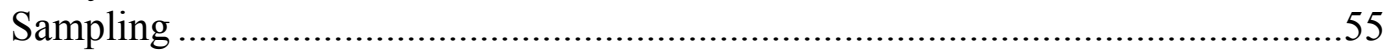

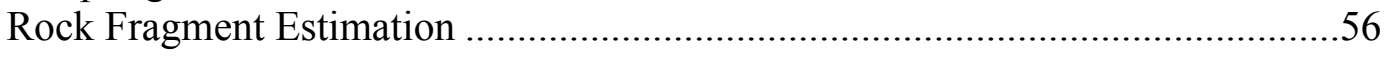

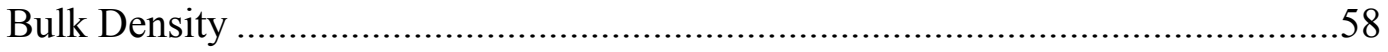

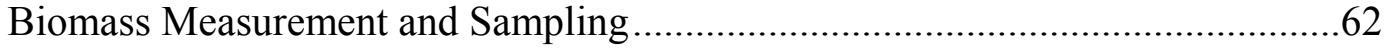

Allometric Equations for Biomass Estimation ................................................64

Dead Woody Debris....................................................................................66

Comparisons of Soil and Vegetative Organic Carbon Estimates .........................68

Chemical Analyses and Nutrient Pools.........................................................68

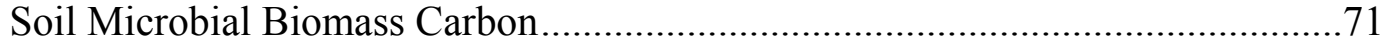

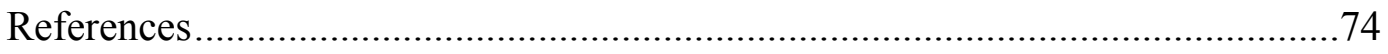

CHAPTER 4. MORPHOLOGY AND TAXONOMY OF THE SOILS ........................81

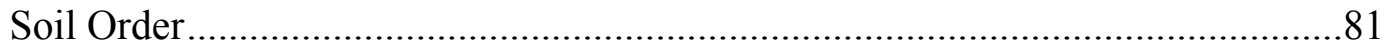

Suborder, Subgroup, and Great Group Classification ................................. 81

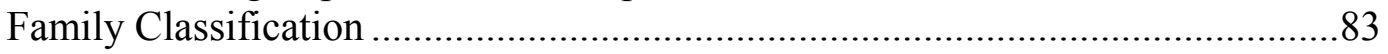

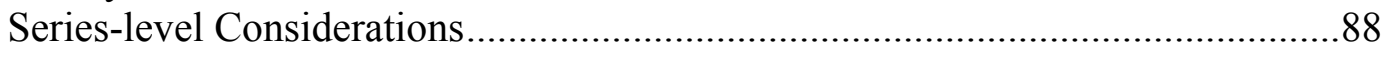

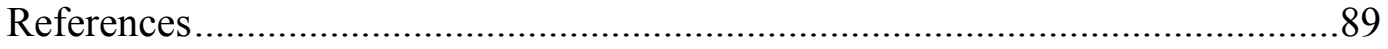

CHAPTER 5. SOIL AND VEGETATION ORGANIC CARBON OF THE

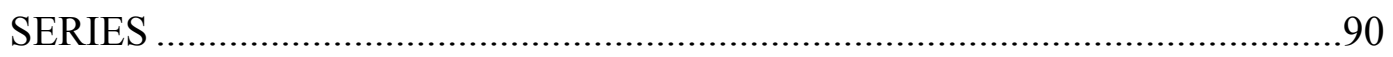

Introductory Remarks ........................................................................ 90

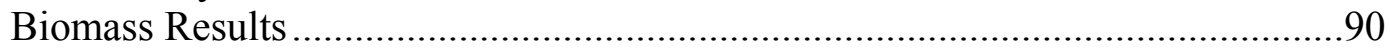


Soil Organic Carbon Results............................................................................96

Dichromate vs. Total (Combustion) Carbon........................................................98

Total Site Organic Carbon (Soil and Vegetation)..............................................99

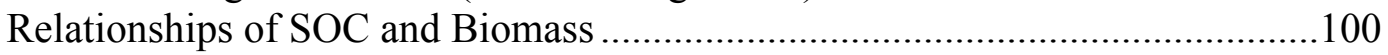

Relationships of SOC and VOC Stocks to Other Soil/Site Characteristics .........105

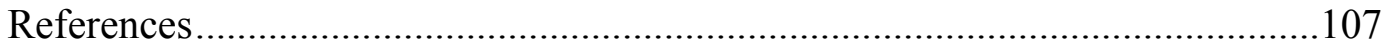

CHAPTER 6. SOIL MICROBIAL BIOMASS CARBON...........................................109

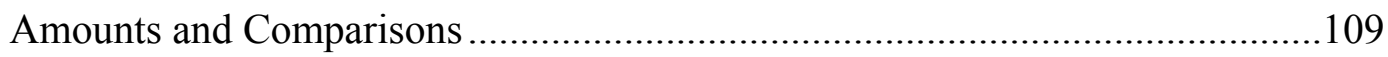

Distributions and Relationships to other Soil Parameters......................................111

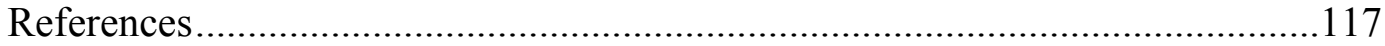

CHAPTER 7. A COMPARISON OF SOIL ORGANIC CARBON STOCKS OF

MAJOR FOREST SOILS ON THE ALLEGHENY PLATEAU OF

WEST VIRGINIA ……………………………….................................119

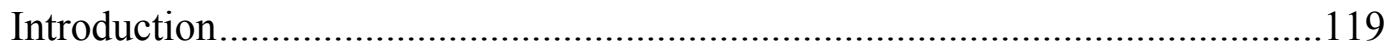

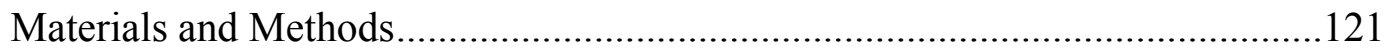

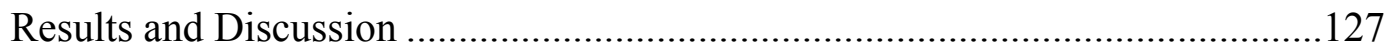

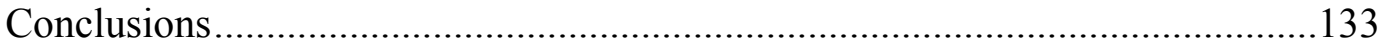

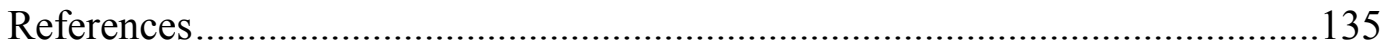

CHAPTER 8. CALCIUM AND MAGNESIUM IN HIGH ELEVATION FOREST

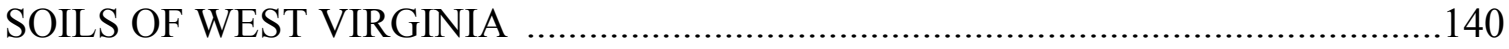

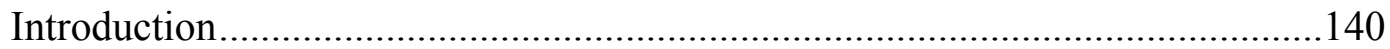

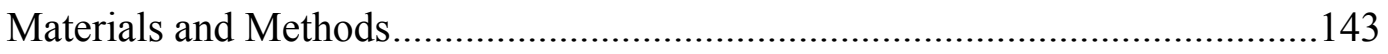

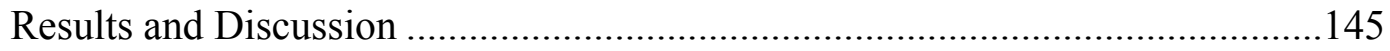

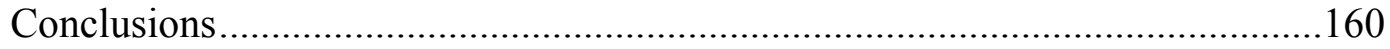

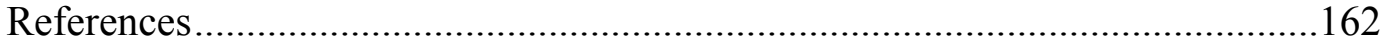

CHAPTER 9. EXTRACTABLE AND TOTAL PHOSPHORUS OF HIGH ELEVATION FOREST SOILS IN WEST VIRGINIA ……………………………………....171

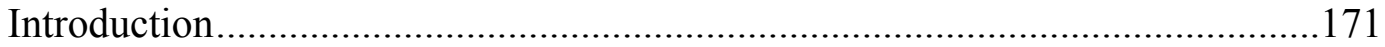

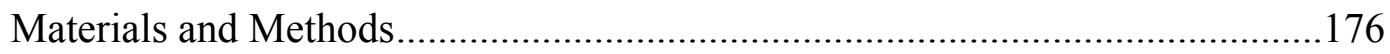

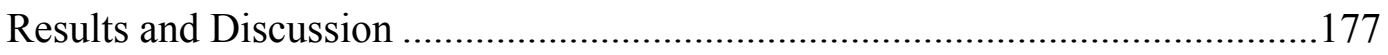

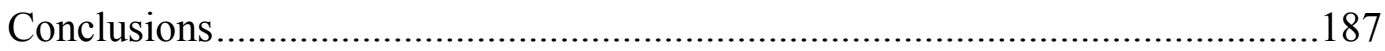

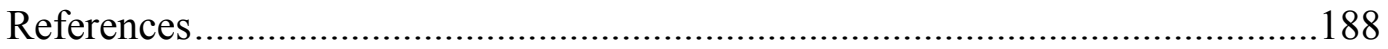

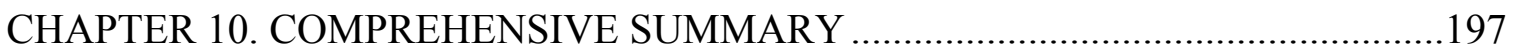


A. Pedon and Site Descriptions of the Series .............................................205

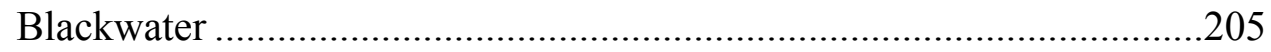

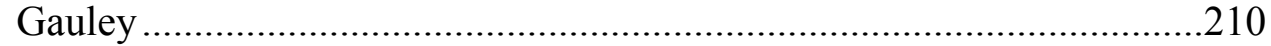

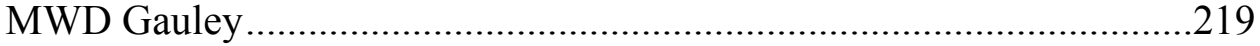

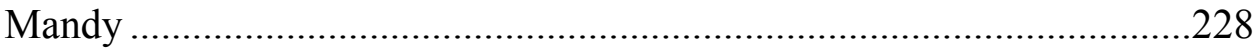

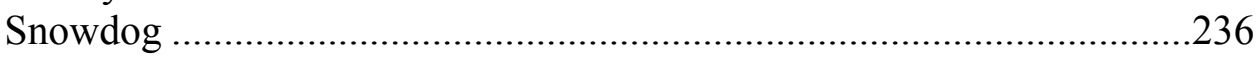

B. Basic Pedon Characterization Data for the Series ...................................246

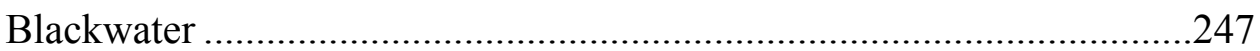

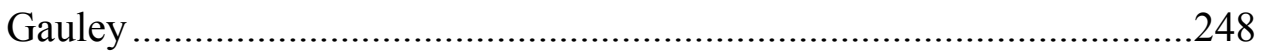

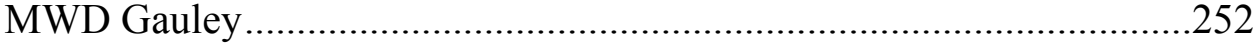

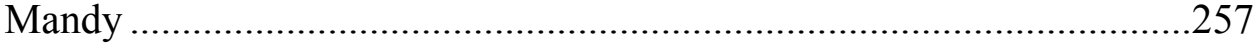

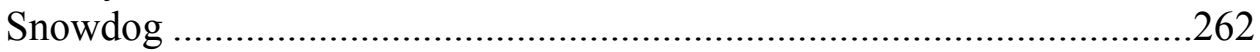

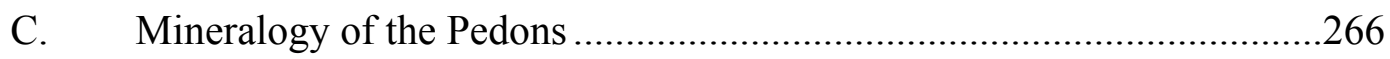

D. Vegetative Biomass Data for the Series..................................................220

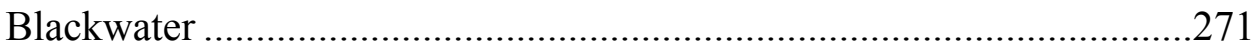

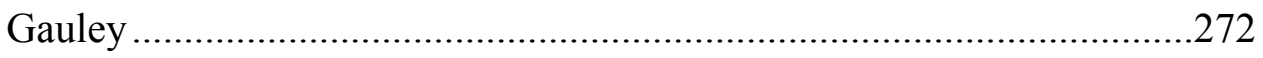

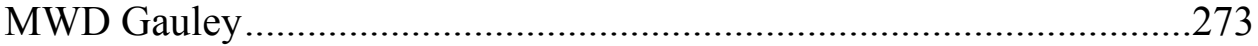

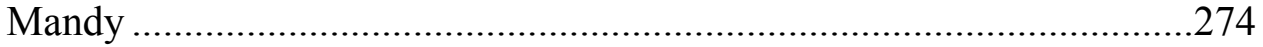

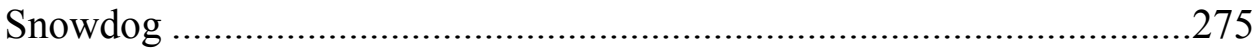

Dead Woody Debris Density Estimates.....................................................22

E. Soil Microbial Biomass Data for the Gauley and Mandy Series .............277

F. Relative Excavation Frame- and Regression-based Estimates of Bulk

Density for the Series.........................................................................279 


\section{LIST OF TABLES}

Table 2.1. A Review of Leaf-fall Biomass for Central Hardwood Forests ................24

Table 3.1. Depth, Drainage, and Typical Landforms of the Series............................55

Table 3.2 Biomass Parameters Measured at the Pedon Sampling Locations ............62

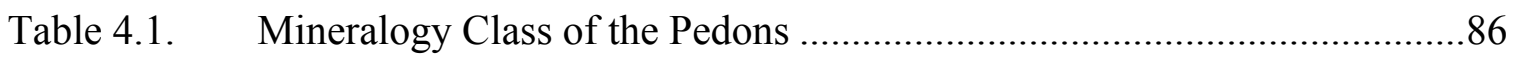

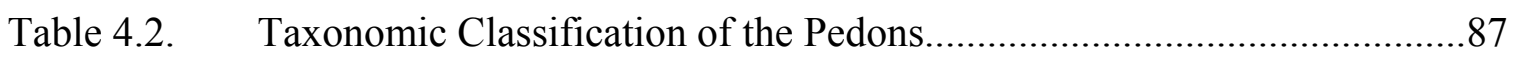

Table 5.1 Biomass of the major frigid series ...................................................92

Table $5.2 \quad$ Above-ground biomass of the series ..............................................93

Table 5.3 Sawtimber $(>12.5 \mathrm{~cm})$ species occurrence for the series........................95

Table 5.4 Soil organic carbon stocks of the frigid series ....................................96

Table 5.5 Soil, vegetation, and total site organic carbon by pedon ........................97

Table 5.6. Summary of Linear Correlations of Soil Organic Carbon and Vegetation Organic Carbon Stocks to Soil Nutrient Stocks and

Site Characteristics....................................................................... 106

Table 6.1. Soil Microbial Biomass Carbon in Two Horizons of the Gauley and

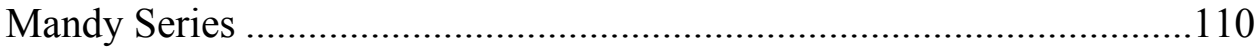

Table 6.2. Statistical Comparisons of Soil Microbial Biomass Carbon for the Series.....

Table 7.1. Correlated Classification and Number of Pedons Sampled of the Soil Series.

Table 7.2. Depth, Drainage, and Typical Landforms of the Series.

Table 7.3. Comparison of Frame Bulk Density Values to Other Forest Soil Studies

Table 7.4. Soil Organic Carbon Stock Estimates for Some Major Forest Soils of West Virginia 130 
Table 7.5. Summary of Statistical Comparisons of Soil Organic Carbon Stocks.....131

Table 7.6. Soil Organic Carbon Stock Estimates for Central and Eastern US

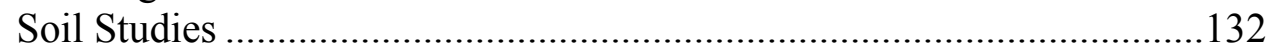

Table 7.7 A Review of Soil Organic Stock Estimates for the Allegheny Plateau Region of West Virginia from Published Models....................................133

Table 8.1. Extractable and Total Calcium and Magnesium for the Series................147

Table 8.2. Relationship of Calcium and Magnesium Concentrations to Soil Organic Carbon and Depth for the Series ..........................................................156

Table 9.1. Extractable and Total Phosphorus for the Series .....................................178

Table 9.2. Percent of Pedon Extractable and Total Phosphorus Found in Forest Floor Horizons of the Series ..........................................................................180

Table 9.3. Ratios of Extractable to Total Phosphorus for the Series .........................181 


\section{LIST OF FIGURES}

Figure 2.1. Site Mediation of Soil Organic Carbon-Determining Factors ....................18

Figure 5.1. Relationship of Soil Organic Carbon to Soil Depth for the Series ..........101

Figure 5.2. Dichromate and Combustion Estimates of Soil Organic Carbon by Depth

for the Series .....................................................................................102

Figure 5.3. Biomass, Soil, and Total Organic Carbon Stocks of the Series................103

Figure 5.4 Soil and Vegetation Organic Carbon for All Sites...................................104

Figure 6.1 Relationship of Total Soil and Soil Biomass Organic Carbon for the Gauley and Mandy Series

Figure 6.2 Relationship of Soil Microbial Biomass Organic Carbon to Base

Saturation of Effective Cation Exchange Capacity

Figure 6.3 Relationship of Soil Microbial Biomass Organic Carbon and Soil pH (in Water) for the Gauley and Mandy Series ................................................114

Figure 6.4 Relationship of Soil Microbial Biomass Carbon and Aluminum Saturation for the Gauley and Mandy Series.........................................................116

Figure 7.1 Frame Versus Regression Bulk Density Estimates for the Series ............128

Figure 8.1 Relationship of Extractable and Total Calcium to Soil Organic Carbon

for the Series

Figure 8.2 Relationship of Extractable and Total Magnesium to Soil Organic Carbon for the Series 150

Figure 8.3. Relationship of Extractable and Total Calcium to Soil Depth for the Series

Figure 8.4. Relationship of Extractable and Total Magnesium to Soil Depth for the Series

Figure 8.5. Relationship of Extractable to Total Calcium for the Series 154

Figure 8.6. Relationship of Base Saturation of Effective Cation Exchange Capacity to Soil Depth for the Series. 
Figure 8.7. Relationship of Extractable Ca:Al to Soil Depth for the Series...............159

Figure 9.1. Relationship of Extractable to Total Phosphorus for the Series

Figure 9.2. Relationship of Extractable and Total Phosphorus to Soil Organic

Carbon......

Figure 9.3. Relationship of Extractable and Total Phosphorus to Soil Depth for the Mandy Series ............................................................................185

Figure 9.4. Relationship of Extractable and Total Phosphorus to Aluminum Saturation 


\section{CHAPTER ONE}

\section{INTRODUCTION}

Storage of carbon in soil is a key factor in the dynamics controlling atmospheric $\mathrm{CO}_{2}$ concentrations. Globally, soil is estimated to contain about $1550 \mathrm{Pg}$ of soil organic carbon (SOC), approximately three times that currently held in living biota, and two times greater than the C content in the atmosphere (Lal et al., 1995). Forest ecosystems, including forest soils, contain an estimated $60 \%$ of terrestrial organic carbon (Lal et al., 1995). Small changes in this pool could dramatically affect atmospheric $\mathrm{CO}_{2}$ levels, and thus the associated re-radiation of long-wave (heat) energy from the atmosphere to the earth; known as radiative forcing (Anderson, 1992). With the exception of water vapor, $\mathrm{CO}_{2}$ accounts for the major portion of radiative forcing in the atmosphere, by virtue of its relatively high concentration (Houghton et al., 1996; Rodhe, 1990).

The atmospheric $\mathrm{CO}_{2}$ concentration has risen from about $260 \mathrm{ppm}$ prior to the industrial revolution to about $380 \mathrm{ppm}$ presently, and is projected to double that by the year 2100 (Hansen et al., 1998; Houghton, 1994; Houghton et al., 1996; Indermuhle et al., 1999; Keeling et al., 1998; Mitchell, 1989). The radiative forcing associated with this increase is probably responsible for global average surface temperature increases of 0.3 to $0.6^{\circ} \mathrm{C}$ over the last 150 years (Nicholls et al., 1996). This is the largest warming trend in at least the last several hundred years (Briffa et al., 1998), and perhaps 1500 years (Prentice et al., 1998). Global mean surface temperatures are expected to continue to rise about $2^{\circ} \mathrm{C}$ 
late in the $21^{\text {st }}$ century, when $\mathrm{CO} 2$ concentrations are approximately twice the current amount (Kattenberg et al., 1996). Glacial melting and sea level rise associated with global warming have been reported in recent years (Krabill et al., 1999; Dyergerov and Mein, 1997; Warrick et al., 1996). Kattenberg et al. (1996) reason that a likely result of warming will be an intensification of the hydrologic cycle in humid regions. For the northern hemisphere, average seasonal temperatures could rise by as much as $4^{\circ}$ and $17^{\circ}$ C in summer and winter, respectively (Mitchell et al., 1990; Schlesinger and Mitchell, 1987). Average temperatures in boreal areas, the major global sinks of SOC, already have risen to an environmentally significant degree, causing increased growing season vegetative activity (Keeling et al., 1998; Myneni et al., 1997), and net losses of SOC from some tundra soils (Oechel and Vourlitis, 1995). Some aggrading eastern and southern hardwood forests are losing SOC, in contrast to predicted successional patterns of accumulation (Trettin et al. 1999; Knoepp and Swank; 1997).

Establishing relationships between forest type and growth stage, and soil and biomass $\mathrm{C}$ dynamics under a changing climate is essential to successful management of $\mathrm{C}$ sequestration and productivity. Baseline inventories of SOC stocks in typical forest soils are increasingly important for understanding climate change effects and forest ecosystem feedback. The spatial occurrence of SOC as related to soil and cover type over differing scales is an important component of efforts to quantify and modify the $\mathrm{C}$ cycle.

Managing forest land use to maximize $\mathrm{C}$ sequestration in soils is a significant focus of contemporary research (e.g. Birdsey et al., 1993; Brown et al., 1996; Kurz and Apps, 
1993; Phillips et al. 1998; Birdsey, 1992; Turner et al. 1995). While it is generally accepted that forest ecosystems have the greatest areal stocks of organic carbon (OC), forest SOC content and dynamics are incompletely understood. Carbon storage in soils and vegetation operates on different time scales. The gloabal residence time of carbon in vegetative biomass is about 9 years, versus an estimated 32 years in soils (Schlesinger, 1997). These $C$ pools are interdependent. Carbon in soils comes from net primary production (NPP), as regulated by decomposition. Net primary production is dependent on soil characteristics and climatic factors. The understanding of these reservoirs and interactions is required before we can deliberately mitigate the $\mathrm{C}$ cycle. Although forest biomass presents the most significant short-term sink of $\mathrm{CO}_{2}$ (Schlesinger, 1995), the management of soil deserves further inquiry. This is true whether one seeks to manage for $\mathrm{C}$ sequestration in soils or biomass. Resource inventories of delineated soil types and their SOC stocks are needed to complement research investigating the mechanisms of SOC accumulation of forest ecosystems (Eswaran et al., 1995).

The primary resource for estimating SOC pools from landscape to regional and global scales is soil survey information. Soil survey activities in the US, particularly sampling and analytical investigation, have historically placed emphasis on the most agronomically important soil series. The present work constitutes an attempt to add to the resource inventory of some extensive forested soil series (established and tentative) that have not previously been sampled. The amounts and distribution of SOC in the context of relevant chemical and physical soil properties, and in association to the forest biomass is assessed herein for several major forest soil series of WV. 


\section{OBJECTIVES}

The primary objective of this study was to report the SOC and forest biomass stocks of some major high elevation forest soil series on the Allegheny Plateau of West Virginia. The secondary, complementary objectives include:

1. Documentation of the classification of the series as published, and as indicated by this study.

2. Examination of the distribution of SOC among the series.

3. Examination of microbial biomass $\mathrm{C}$ amounts in selected soils.

4. Comparison of the SOC stocks of the series of this study (frigid) with similar soils having higher mean annual soil temperature (mesic) in West Virginia.

5. Examination of the distribution of SOC as related to other soil fertility factors pertinent to forest productivity and $\mathrm{C}$ sequestration. These include:

1. Effective cation exchange capacity (ECEC)

2. Extractable and total $\mathrm{Ca}, \mathrm{Mg}$; and extractable and total $\mathrm{P}$.

3. Relative base or Al saturation of the soil exchange matrix.

6. Examination of $\mathrm{Ca}$ and $\mathrm{Mg}$ stocks and distribution among the frigid series.

7. Examination of extractable and total P stocks and distribution among the frigid series. 


\section{APPROACH}

The form of this thesis will proceed in a fashion of the presentation of an Introduction, Literature Review, and Materials and Methods chapters, followed by six chapters serving as Results and Discussion sections. The first of these will establish the taxonomic classification of the soils sampled, including a presentation of morphological and other data pertinent to classification and interpretation. The second is designed to present and briefly discuss the resulting SOC, vegetative biomass, and vegetative organic carbon (VOC) estimates. The third chapter will relate the results of analyses relating to soil microbial biomass $\mathrm{C}$ distribution. These chapters are intended to both give information of independent interest and to provide context for the following chapters. The following three chapters are fashioned as individual works (in preparation of publication). These individual sections cover the following topics:

1. SOC and forest biomass stocks and distribution: comparison of frigid and mesic series.

2. Exchangeable and total $\mathrm{Ca}$ and $\mathrm{Mg}$ stocks and distribution, and $\mathrm{Al}$ distribution. Relationships of SOC to these elements and associated fertility criteria.

3. Extractable and total P stocks and distribution. Relationships of SOC to P and associated fertility criteria

The above-described sections contain independent Discussion, Conclusion, and Reference sections. The final chapter presents an overall conclusion section, called a Comprehensive Summary. 


\section{REFERENCES}

Anderson, J.M. 1992. Responses of soils to climate change. Adv. Ecol. Res. 22:163-210.

Birdsey, R.A. 1992. Changes in forest carbon storage from increasing forest area and timber growth. p. 23 - 39. In Sampson, R.N. and D. Hair (ed.) Forests and global change. Vol. 1: Opportunities for increasing forest cover. American Forests, Washington DC.

Birdsey, R.A., A.J. Plantinga, and L.S. Heath. 1993. Past and prospective carbon storage in United States Forests. For. Ecol. and Mngmt. 58:33 - 40.

Briffa, K. R., P. D. Jones, F. H. Schweingruber, and T. J. Osborn. 1998. Influence of volcanic eruptions on Northern Hemisphere summer temperature over the past 600 years. Nature 393(6684):450-455.

Brown, S.L., J. Sathaye, M. Cannell, and P. Kauppi. 1996. Mitigation of carbon emission to the atmosphere by forest management. Commonwealth Forestry Review 75(1):80-91.

Dyurgerov, M. B., and M. Meier. 1997. Mass balance of mountain and sub-polar glaciers: A new global assessment for 1961-1990. Arctic and Alpine Research 29(4):379-391. 
Eswaran, H., I. Van den Berg, P.Reich, and J. Kimble. 1995. Global Soil Carbon

Resources. p. 27-43. In R. Lal et al. (ed.) Soils and global change. CRC Press, Boca Raton, FL.

Hansen, J. E., M. Sato, A. Lacis, R. Ruedy, I. Gegen, and E. Matthews. 1998. Climate forcings in the industrial era. Proceedings of the National Academy of Sciences. 95(12):753-758.

Houghton, .R.A. 1994. Changes in terrestrial carbon over the last 135 years. In: M.Heimann (ed.) The global carbon cycle. Springer-Verlag, Berlin.

Houghton, J. T., L. G. M. Filho, B. A. Callander, N. Harris, A. Kattenberg, and K. Maskell. 1996. Climate Change 1995: The Science of Climate Change, Intergovernmental Panel on Climate Change. Cambridge University Press, Cambridge, GB. 572 pp.

Indermuhle, A., T. F. Stocker, F. Joos, H. Fischer, H. J. Smith, M. Wahlen, B. Deck, D. Mastroianni, J. Tschumi, T. Blunier, R. Meyer, and B. Stauffer. 1999. Holocene carboncycle dynamics based on $\mathrm{CO}_{2}$ trapped in ice at Taylor Dome, Antarctica. Nature 398:121126.

Kattenberg, A., F. Giorgi, H. Grassl, G. A. Meehl, J. F. B. Mitchell, R. J. Stouffer, T. Tokioka, A. J. Weaver, and T. M. L. Wigley. 1996. Climate models - projections of 
future climate. p. 285-357. In J. T. Houghton et al. (ed.) Climate Change 1995: The Science of Climate Change. Cambridge University Press, Cambridge, UK.

Keeling, C. D., and T. P. Whorf. 1998. Atmospheric $\mathrm{CO}_{2}$ records from sites in the SIO air sampling network. In Trends: A Compendium of Data on Global Change. Carbon Dioxide Information Analysis Center, Oak Ridge National Laboratory, Oak Ridge, Tenn.

Knoepp, J.D., and W.T. Swank. 1997. Forest management effects on surface soil carbon and nitrogen. Soil Sci. Soc. Am. J. 61:928-935.

Krabill, W., E. Frederick, S. Manizade, C. Martin, J. Sonntag, R. Swift, R. Thomas, W. Wright, and J. Yungel. 1999. Rapid thinning of parts of the southern Greenland ice sheet. Science 283:1522-1524.

Kurz, W.A., and M.J. Apps. 1993. Contribution of northern forests to the global carbon cycle: Canada as a case study. Water, Air, Soil Pollution 70:163-176.

Lal, R., J. Kimble, E. Levine, and C. Whitman. 1995. World soils and greenhouse effect: An overview. p. 1-7. In R. Lal et al. (ed.). Soils and global change. CRC Press, Boca Raton, FL.

Mitchell, J.F.B. 1989. The "Greenhouse" effect and climate change. Reviews of Geophysics 27:115-139. 
Mitchell, J.F.B., S. Manabe, S. Tokioka, and V. Meleshko. 1990. Equilibrium climate change and its implications for the future. p. 131-178. In J.T. Houghton, G.J. Jenkins, and J.J. Ephraums (ed.) Climate change, the IPCC scientific assessment. Cambridge, U.K., Cambridge University Press.

Myneni, R. B., C. D. Keeling, C. J. Tucker, G. Asrar, and R. R. Nemani. 1997. Increased plant growth in the northern high latitudes from 1981 to 1991. Nature 386:698-702.

Nicholls, N., G. V. Gruza, J. Jouzel, T. R. Karl, L. A. Ogallo, and D. E. Parker.1996. Observed climate variability and change. p.133-192 . In J. T. Houghton et al. (ed.) Climate Change 1995: The Science of Climate Change. Cambridge University Press, Cambridge, UK.

Oechel, W.C., and G.L. Vourlitis. 1995. Effect of global change on carbon storage in cold soils. p. 17-129. In R. Lal et al. (ed.) Soils and global change. CRC Press, Boca Raton, FL.

Phillips, D., P. Schroeder, S. Brown, and R. Birdsey. 1998. Land cover dynamics and greenhouse gas emissions: error analysis of large-scale forest carbon budgets. GCTELUCC Open Science Conference on Global Change: The Earth's Changing Land, Abstracts. Institute Cartografic de Catalunya, Barcelona, Spain, p. 97. 
Prentice, I. C., S. P. Harrison, D. Jolly, and J. Guiot. 1998. The climate and biomes of Europe at 6000 yr BP: Comparison of model simulations and pollen-based reconstructions. Quaternary Science Reviews 17 (6-7):659-668.

Rodhe, H. 1990. A comparison of the contribution of various gases to the greenhouse effect. Science 248:1217-1219.

Schlesinger, W.H. 1997. Biogeochemistry: An Analysis of Global Change. $2^{\text {nd }}$ ed. Academic Press, San Diego.

Schlesinger, W.H. 1995. An overview of the carbon cycle. p. 9-25. In R. Lal et al. (ed.) Soils and global change. CRC Press, Boca Raton, FL.

Schlesinger, W.H., and J.F.B. Mitchell. 1987. Climate model simulations of the equilibrium climatic response to increased carbon dioxide. Rev. Geophys. 25:760-798.

Trettin, C.C., D.W. Johnson, and D.E. Todd, Jr. 1999. Forest nutrient and carbon pools at Walker Branch watershed: Changes during a 21 year period. Soil Sci. Soc. Am. J. $63: 1436-1448$.

Turner, D.F., G.J. Koerper, M.E. Harmon, and J.J. Lee. 1995. A carbon budget for forests of the coterminous United States. Ecol. Appl. 5 (2):421-436. 
Warrick, R. A., C. L. Provost, M. F. Meier, J. Oerlemans, and P. L. Woodworth. 1996.

Changes in sea level. p. 359-405. In J. T. Houghton et al. (ed.) Climate Change 1995: The Science of Climate Change. Cambridge University Press, Cambridge, UK. 


\section{CHAPTER TWO}

\section{LITERATURE REVIEW}

\section{SOIL ORGANIC CARBON: AMOUNTS AND DISTRIBUTION}

Estimates of SOC pools are important and evolving components of models used for global climate change prediction (Lal et al., 1995). Different soils have different rates of C accumulation (Schlesinger, 1997). Although SOC is a function of land use and climatic variables, the state factors (Jenny, 1980) that determine a soil also determine whether the soil is likely to be a net sink or source of carbon. It is known that while the global soil sink is estimated to sequester about $2 \mathrm{~g} \mathrm{C} \mathrm{m}^{-2} \mathrm{yr}^{-1}$ (Schlesinger, 1990), spodic horizon formation can involve the accumulation of up to $55 \mathrm{~g} \mathrm{C} \mathrm{m}^{-2} \mathrm{yr}^{-1}$ ( Harden et al., 1992). Conversely, some alfisols and inceptisols may have lower or negative C sequestration rates (Bouman and Leemans, 1995). In the high elevation areas of West Virginia, soil survey activities are underway to more accurately describe and map forest soils, which are dominated by inceptisols and spodosols (e.g. Delp, 1998; Flegel, 1999).

Soil organic carbon amounts, distribution, and areal extent are an acknowledged data gap in the high elevation Appalachian region for larger $\mathrm{C}$ distribution and climate models (Grossman, 1991). Existing regional SOC spatial data are not based on actual SOC studies of this area, but on estimates contained either in soil databases (Bliss et al., 1995) or from soil survey characterization information gathered for other purposes (Kern, 1994; Davidson and Lefebvre, 1993; Eswaran et al., 1995). Characteristics such as land use and 
land use history, sampling protocols, sampled pedon morphological information, and pedon locations are poorly documented, inconsistent, or unknown for many of the sources of SOC data incorporated into existing models of regional SOC stocks. Recent research indicates a need for increased focus on "forest floor" $(\mathrm{O})$ horizons, as well as improving the bulk density $(\mathrm{Db})$ estimates of horizons which are high in SOC (Eswaran et al., 1995; Homann et al., 1995; Huntington et al., 1989; Snyder and Pilgrim, 1985).

Eswaran et al. (1995) outline many of the difficulties associated with global SOC estimates. Similar difficulties are presented by attempts at more localized estimates (Arnold et al., 1995). Presently, SOC estimates for the United States (US) are based on information derived either from pedon data compiled by the USDA-Natural Resources Conservation Service (NRCS) (Eswaran et al. 1993,1995; Kern 1994; Post et al. 1982),or from generalized soil series characteristics contained in NRCS Soil Interpretation Records (SIR's) (Bliss et al., 1995). These studies incorporate various spatial strategies utilizing either ecological-based or soil maps. The estimates of SOC pools for this study area vary from high values of $32 \mathrm{~kg} \mathrm{~m}^{-2}$ (Kern, 1994, ecosystem-based) to a low of $2.2 \mathrm{~kg}$ $\mathrm{m}^{-2}$ (Bliss et al., 1995). The pedon laboratory data for this region are primarily from the National Soil Survey Laboratory (NSSL), or to a lesser extent, land-grant universities. Each SIR contains generalized information including $\mathrm{Db}$ and organic carbon percentage ranges for "layer depths" that are representative of horizon groups typical of a given soil series. For the series of this region, the SIRs do not contain information about $\mathrm{O}$ horizons. The $\mathrm{Db}$ values included in both the pedon data and SIRs are ranges based on the clod method (Blake and Hartge, 1986). The applicability of clod Db information to 
upper horizons of forest soils may be subject to error due to the higher organic matter, root occurrence, and rock fragment content (Huntington et al., 1989).

\section{SOIL ORGANIC CARBON: OCCURRENCE, CHARACTERISTICS, AND IMPORTANCE}

The biomass on the forest floor and from roots constitute the primary source of forest SOC (Harris et al., 1977; Mellilo et al., 1989; Nadelhoffer et al., 1985). Contributions of SOC from larger woody debris (e.g. boles and coarse roots) are significant (e.g. Alban and Pastor, 1993; Harmon et al., 1986; Muller and Liu, 1991), but constitute a relatively small input when compared to annual leaf-fall and fine root turnover (Joslin and Henderson, 1987; Kaczmarek et al., 1995). Relatively small SOC contributions come from fauna that contain C from off-site primary producers (Schlesinger, 1997).

Organic matter deposited on and in soil is acted upon by a series of decomposer communities that functionally serve to increase the surface area and humification of the SOM pool (Paul and Clark, 1996). Humus is not a very specific term; Paul and Clark (1996) define it as basically a brown substance with less C and more oxygen than most animal and plant residues. Humification, and thus humus, largely equates to the SOM products of chemoheterotrophic organisms as a consequence of their attempts to convert a myriad of $\mathrm{C}_{6} \mathrm{H}_{12} \mathrm{O}_{6}$ compounds to $\mathrm{CO}_{2}$. This results in a distribution of very different kinds and quantities of SOC over the depth of a typical forest soil profile in this region. The SOC in a forest soil pedon exists in forms from practically undecomposed litter to material humified nearly to the extent of elemental C. Humic substances are discussed in 
more detail below. Plant material - depending on species, size, age, and site conditions requires time scales of hours or decades for some level of decomposition to occur. Soil organic matter may have a half-life expressed in hours or millennia, depending on its degree of physical and chemical stabilization (Paul and Clark, 1996).

Most of the total soil respiration, and thus, OM alteration, occurs in the upper horizons of the soil (Andrews et al., 1999). These layers, often referred to as the forest floor, are the Oi, Oe, Oa, and sometimes A horizons. The vast majority of both detritus and fine root biomass turnover occur in forest floor horizons. About $80 \%$ of total fine root biomass is contained in the upper 20 to $30 \mathrm{~cm}$ of forest soils (Fahey et al., 1988; Kelly and Joslin, 1989). Soil macro- and mesofauna are particularly important in these horizons for initial decomposition processes. Fungal, and to a lesser extent in acid soils, bacterial populations are important associates of larger biota and roots in the forest floor (McColl and Gressel, 1995; Paul and Clark, 1996). Fungal and bacterial colony forming units in upper horizons of forest soils often exceed 1 million per gram (McColl and Gressel, 1995; Paul and Clark, 1996).

Within these horizons most of the "light" or "active" (Duxbury, 1991) SOM fraction of carbohydrates and readily degradable cellulose is decomposed. The turnover time for these materials is generally expressed in decades or less (Schlesinger, 1997). Paul and Clark (1996) note that the time scale for decomposition measurements that include carbohydrates is in minutes or hours in the upper soil layers.

As soil depth increases, the SOC pool becomes less oxidizable, and more structurally protected inside microaggrates or complexed with clay minerals (Eswaran, 1979). Below 
the $\mathrm{O}$ horizons, SOC content is primarily associated with metabolic products from several trophic levels above (Fisher, 1995). These much more recalcitrant compounds are generally referred to as humic substances or the humus fraction (Duxbury, 1991). They are often closely related to lignin and soil biota metabolites of lignin defined by the vegetation present (Paul and Clark, 1996). They account for much of the cation exchange capacity of acid forest soils, and via their influence on soil structure they benefit soil physical properties critical to water, gas, and root movement (Brady and Weil, 1999; Stevenson, 1994).

Humic substances are a very complex and largely uncharacterized group of typically aromatic organic acids and polyphenolic compounds (Stevenson, 1994). Humus has historically been characterized by chemical fractionation into three broad categories (Stevenson, 1994): humin, insoluble in water; humic acid, insoluble below $\mathrm{pH}=2$; and fulvic acid, which is soluble in water and has lower molecular weight than humic acids. Functionally, the humin fraction is generally that most associated with lignins (large, poorly defined aromatic polymers) and lipids (heterogeneous fats, waxes, and oils insoluble in water). The turnover time for humus ranges from decades for some fulvic acids to millennia in the case of humin and some humic acids (Schlesinger, 1997; Stevenson, 1994).

Forest soils appear to be relatively higher in fulvic acids than grassland soils, which have more humic acid domination of SOM (Stevenson, 1994). Fulvic acids are the major SOC species that chelate and precipitate/co-precipitate with Fe and Al in spodic (Bhs/Bs) horizons (Stevenson, 1994; Browne, 1995). Fulvic acids and smaller (low molecular 
weight) organic acids can be highly important in Al regulation and nutrient cycling phenomena (Fox, 1995; Henderson, 1995; Johnson 1995; Wolt, 1994).

\section{SOIL ORGANIC CARBON: DETERMINING FACTORS}

Generally, the primary determinants of net SOC accumulation are ecosystem net primary productivity (NPP) of biomass and soil respiration (Schlesinger, 1995, 1997). Vegetative biomass on the soil is generally the NPP less those losses to harvesting, burning, and herbivory. While biomass from photoautotrophs (trees) provides the major SOC input, chemoheterotrophic respiration dominates the soil micro- and meso-faunal activities that constitute the major output from the SOC pool (Winkler et al., 1996). These primary inputs and outputs are driven and regulated by a number of often interdependent factors at any given site (Figure 2.1). 


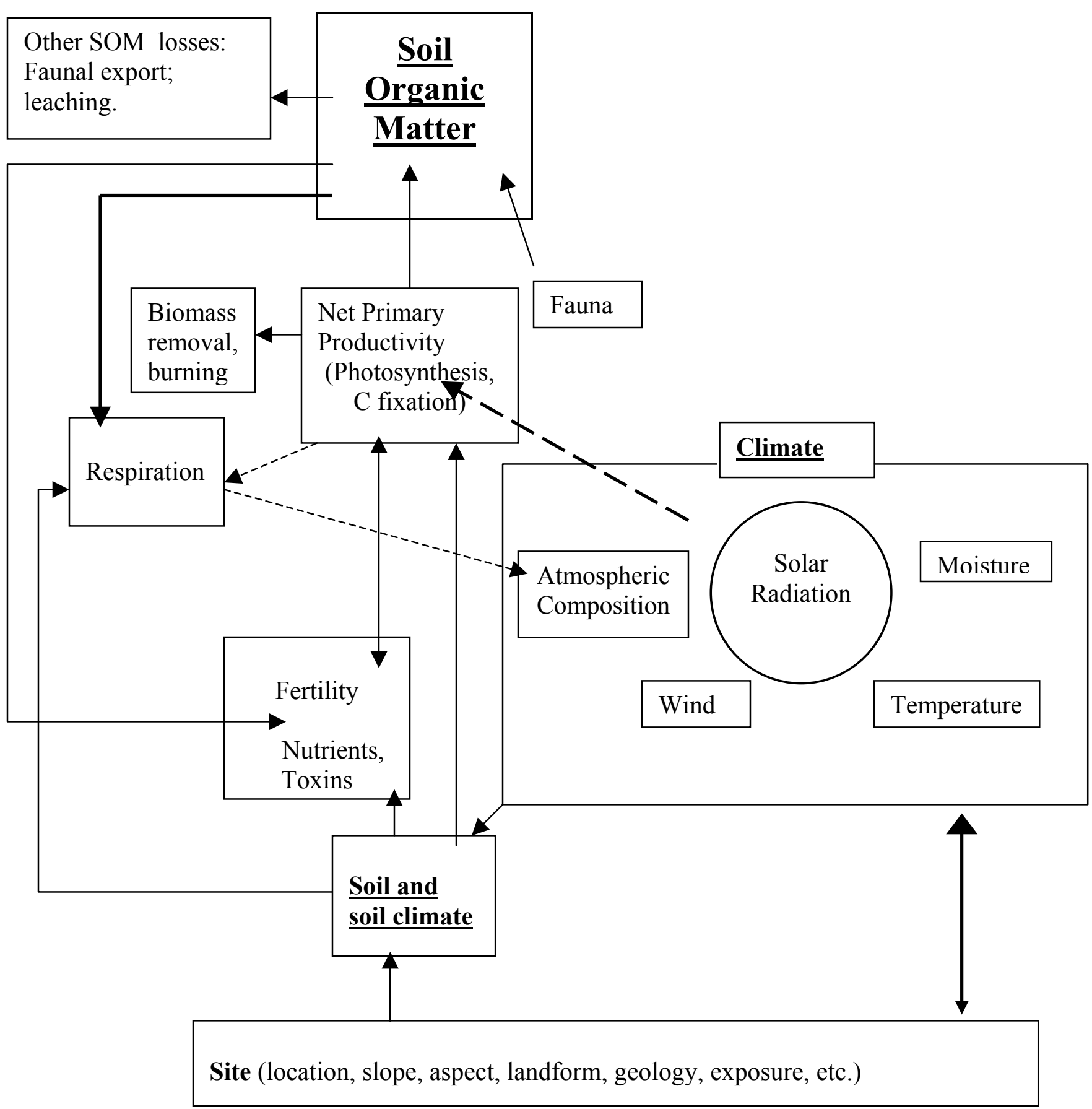

Figure 2.1. Site mediation of SOC-determining factors. 
The overall rate of SOC accumulation is not rapid, particularly in upland forest systems. Schlesinger $(1990,1995)$ notes that less than 1 percent, (about $0.7 \mathrm{Pg}$ ), of annual global NPP is stored in soils. Although a significant portion of NPP is intercepted prior to deposition on many forest soils, SOC is clearly a minor annual compartment for biomass storage. This seemingly very low rate of accumulation of SOC is a result of the environmental scenario in which the biologically-regulated processes of $\mathrm{C}$ dynamics operate. Photosynthetic activity depends on the availability of sunlight, and operates in an atmosphere where temperature and moisture conditions change rapidly. Conversely, the respiring organisms in the soil exist in a medium that is favorable for metabolic activity that is relatively unrestricted by diurnal changes, and is well buffered from other climatic extremes. Root and microbial biomass respiration continues well beyond the photosynthetic growing season (Paul and Clark, 1996).

Respiration in the forest soil environment results in $\mathrm{CO}_{2}$ evolution from contemporary forest vegetation via roots and mycorrhizal associates, from heterotrophs that consume root exudates and tissue; and from heterotrophic catabolism of other SOM. Tree roots have been estimated to be responsible for 5 to 90 percent of total soil respiration. In attempts to estimate SOC residence times for global C balancing, Schlesinger (1997) suggests using 30 percent as the portion of soil respiration from roots. Measuring soil $\mathrm{CO}_{2}$ fluxes using stable carbon radio isotope tracers in a loblolly pine (Pinus taeda) forest, Andrews et al. (1999) propose 55\% as a more reasonable growing-season estimate for that system. Either way, vegetation composes a significant portion of the contributions to total soil respiration in forested ecosystems. The type and development 
of the forest stand, and time of year no doubt are critical to the relative sources of respiration in forest soils.

Adequate moisture supplies are required for both photosynthesis and respiration, thus both NPP and organic matter mineralization are minimal in arid environments. At the extremes of wetland conditions, however, the restriction of soil respiration due to the loss of $\mathrm{O}_{2}$ as an electron acceptor allows the accumulation of great quantities of SOC (Paul and Clark, 1996; Schlesinger, 1997). It is this relationship that accounts for the fact that wetland soils are generally the highest in SOC storage, if not always in annual NPP.

Given sufficient moisture, mean annual temperature correlates positively with NPP (Schlesinger 1977,1997; Vitousek et al. 1988) and soil respiration (Lloyd and Taylor, 1994; Wiant, 1967; Winkler et al., 1996). Regionally, the exponential relationship of soil organism respiration apparently outweighs the increase in NPP as temperature increases (Jenny, 1980; Post et al. 1982; Raich and Schlesinger, 1992). This is evidenced by the phenomenal NPP, yet relatively low SOC reserves, of tropical forest ecosystems (Post et al., 1982; Eswaran et al., 1995).

Net primary productivity and SOC dynamics are affected by factors other than moisture and temperature. The geochemical fertility of the soil environment affects the amounts and kinds of biomass inputs. Species diversity, site index, biomass production, SOC, and fertility have been shown to be greater on north- than south-oriented aspects in West Virginia (Hicks and Frank, 1984; Tajchman and Wiant, 1983; Tajchman et al., 1996). Soil respiration and decomposition rates are also strongly influenced by the kinds and amounts of C inputs from biomass (Mudrick et al., 1994, Raich and Schlesinger, 1992). 
Lignin content, as well as other fertility parameters, can limit soil respiration (Meentemeyer, 1978; Mellilo, 1982). Acid precipitation may limit SOC sequestration due to competition of $\mathrm{SO}_{4}^{-2}$ with dissolved organic carbon compounds for anion exchange capacity (Moore, 1997), and other interferences as a result of increasing $[\mathrm{H}+]$ and $\mathrm{Al}$ species.

The environmental factors that control NPP and decomposition warrant further attention. Of particular interest is the effect of climate. Well known is the fact that soil moisture is largely determinate of both biomass productivity and soil organic matter mineralization rates. Actual evapotranspiration is closely related to both NPP and soil respiration (Meentemeyer, 1978). Extremes of available moisture account for deserts and peat bogs, where SOC and biomass carbon (BC) are generally lowest and highest, respectively. The influence of mean annual soil temperature (MAST) on SOC has been demonstrated over relatively large distances. Numerous studies document the inverse relationship between MAST and SOC storage. This negative relationship has been shown at continental (Jenny, 1980; Post et al., 1982) and regional (Kirschbaum, 1995; Post et al., 1982, 1990; Franzmeier et al., 1985) scales, although at least one instance of a positive relationship has been proposed (Homann et al., 1995).

In these studies, the temperature regime changes are often accompanied by significant changes in other "state" factors for soil formation and/or NPP effects. The general picture presented in regional assessments of SOC stocks across climatic gradients as demonstrated by Jenny (1980), Post et al. (1982), and Franzmeier et al. (1985) cannot account for the influences of changes in other soil forming factors. It is generally true that as one proceeds north in the udic areas of the above studies, soil age and degree of 
weathering decreases (Buol et al., 1997). Indeed, parent materials and even landform age change significantly proceeding from the moist, thermic coastal plains up into the glacially derived frigid soils in the northern portion of Jenny's (1980) study area. What influence on SOC might be expected if only MAST was changed over time periods significant to soil and ecosystem development? The geomorphic characteristics of the Allegheny Plateau of West Virginia allow the comparison of forested soils in mesic and frigid temperature regimes which are nearly equivalent in other pedologic aspects, as well as being adjacent in occurrence.

\section{SOIL ORGANISMS}

The activity of soil organisms to the forest soil ecosystems of this region are highly significant. They play critical roles in the release of nutrients from minerals and organic matter, in the chelation of $\mathrm{Al}$ and $\mathrm{Fe}$ and other metals, in redox phenomena, in soil gas composition, in rhizosphere biochemistry, and in the storage and release of plant nutrients. Macrofauna, mesofauna, microorganisms, and plant roots interplay to determine the distribution and speciation of SOC (Paul and Clark, 1996).

The function of organisms in forest soils follows the dynamics of substrate occurrence and utilization. Forest SOM is more lignified and its occurrence is more stratified than that of other cover types. Leaves and other vegetative matter are prepared for soil microbial metabolism largely via the mastication or digestion by mesofauna (Paul and Clark, 1996). Woody debris and lignin-rich materials both in and on the soil are the fodder of various mesofauna; and of basidiomycetes and ascomycetes, known as white 
rot fungi. Their lignocellulytic activity within woody debris is necessary for the subsequent function of other soil organisms, releasing mineral nutrients from resistant organic matter fractions. Enzymatic interactions make possible the complementary decomposition processes of multiple trophic levels. Along with lignin and other substrate decomposition, microorganisms regulate nutrient transformations, which in turn often control organic matter dynamics and thus soil nutrient cycling as a whole. This is particularly true for $\mathrm{N}$ dynamics (Mellilo et al., 1982).

Soil microbial biomass (SMB) is higher in forest soils than in similar grassland or cropland soils, and generally more dominated by fungal components due to acidity and substrate characteristics (Paul and Clark, 1996). In deciduous forests particularly, litter inputs are large (Table 2.1) and seasonally well defined. Both the physical and chemical substrate characteristics of forest soils favor the sustained maintenance of chemoorganotrophic populations. Microbial biomass in forest soils is greatly weighted toward the upper horizons, paralleling SOC (substrate) content and rooting density. Fungal and bacterial colony forming units in upper horizons of forest soils often exceed 1 million per gram (McColl and Gressel, 1995; Paul and Clark, 1996). Soil microbial biomass carbon (SMBC) decreases rapidly with distance from the rhizosphere (Paul and Clark, 1996). Bacterial populations are particularly highly associated with the rhizosphere (Horwath, 1993). Fungi appear to be relatively more dominant than bacteria in acid forest soils, more so with increasing depth. Horwath (1993) reported the ratio of fungi to bacteria $\mathrm{C}$ to range from 2 to 7 as soil depth increased from the top $25 \mathrm{~cm}$ to one meter deep in a Populus plantation soil. 
Table 2.1. A review of leaf-fall biomass for central hardwood forests.

Source

Chandler (1994)

Johnson et al.

(1985)

Joslin and

Henderson (1987)

Rodkey et al. (1995)
Forest type

mixed mesophytic

mixed oak

mixed oak

mixed oak
Leaf-fall

$\left(\mathrm{Mg} \mathrm{ha}^{-1} \mathrm{yr}^{-1}\right)$

2.5-3.0

5.4

5.2

4.5

In addition to their regulation of SOM dynamics, soil biota are a significant portion of what is typically measured as SOC. Viruses, bacteria, fungi, mesofauna, and even fine roots are present in most soil samples, and affect estimates of $\mathrm{C}$ and other elements. Soil biomass composed from 1 to 2 percent of total SOC over a $1 \mathrm{~m}$ depth underlying an hybrid poplar plantation (Horwath, 1993). Microbial biomass often holds significant reservoirs of nutrients such as N and P (Entry et al., 1992; Paul and Clark, 1996). It is conceivable that microbial biomass may be a more important factor for tree growth than SOC or SOM amounts (Fisher, 1995).

In forest soil ecosystems, soil fungi are the indispensable associates of tree roots. Ectomycorrhizae, arbuscular, and ericoid mycorrhizae are symbionts of many types of trees and shrubs found in the forests of this region (Paul and Clark, 1996). Ectomycorrhizae and arbuscular mycorrhizae are most commonly associated with 
commercial tree species. On extremely acid sites, ericaceous vegetation such as mountain laurel (Kalmia latifolia L.) and big laurel (Rhodendron maximum L.) are known to be associated with the more acid and Al tolerant ericoid mycorrhizae (Paul and Clark, 1996).

Mycorrhizal associates are critical to P dissolution and uptake, and important for various other chelating and mineral weathering phenomena (Fogel, 1980; Griffiths et al., 1994; Mineo et al., 1987), especially in less fertile soil environments (Paul and Clark, 1996; Walker and McLaughlin, 1991). They are known to chelate heavy metals, yet aid in the uptake of essential trace metals such as zinc (Paul and Clark, 1996). They are also probably involved in Ca uptake (Mineo et al., 1987). In some cases they even perform antipathogenic functions for plants (Marx, 1978) and may produce hormones that prolong root life (Meyer, 1974). Bacteria probably perform many similar functions, and are an important component of the total forest soil nutrient pool (Illmer and Shinner, 1992). Paul and Clark (1996) propose that $\mathrm{P}$ is perhaps a growth limiting element in most terrestrial and aquatic ecosystems, not as a result of total concentrations, but rather of the dynamics affecting its availability. They note that soil organisms provide bioavailable $\mathrm{P}$ in solution by catalyzing both the dissolution of labile pools and the mineralization of organic pools. Organic pools are the major P source in highly weathered, acid soils such as those dominant in much of West Virginia.

\section{MEASURING SOIL MICROBIAL BIOMASS CARBON}

As discussed above, SMB and SMBC are important mediators and reservoirs, respectively, of total soil organic carbon. The interdependent characteristics of substrate 
amounts and quality, SMB activity, and SMBC amounts and distribution are poorly characterized in acid forest soils. Measurement of SMBC in the higher elevation forest soils of WV has not been performed, so far as this author could find.

Soil microbial biomass measurement is difficult due to the heterogeneous nature of the medium and the multitudes of organisms that are usually present. The chloroform fumigation method is perhaps the most common means of assessing the proportion of SOC attributable to living organisms (Joergensen, 1995; Paul and Clark, 1996). The method has been applied to forest soils, although the presence of fine roots and the typically high acidity complicates measurement considerably (e.g. Vance et al., 1987a, b). Therefore, while absolutely quantifying organisms in forest soils is a daunting proposition, obtaining estimates of soil biomass carbon for comparison purposes is possible with reasonable precision (Vance et al., 1987b, c).

\section{SOIL ORGANIC CARBON: CLIMATE CHANGE EFFECTS}

Increasing average global temperatures and $\mathrm{CO}_{2}$ concentrations are likely over the coming century (Schlesinger, 1997; Houghton et al., 1996). Vegetative NPP may be more responsive to increased $\mathrm{CO}_{2}$ than subsurface biota. Murthy et al. (1996) cite works documenting photosynthetic increases of from 20-200 percent by doubling ambient $\mathrm{CO}_{2}$ concentrations. Increased carbon assimilation will likely coincide with an increase in forest-level water use efficiency (Schlesinger, 1995; 1997), thus possibly conserving soil moisture during growing seasons. The long-term effect that such moisture relationships will have on SOC levels is not clear, but increased respiration is likely. Ball and Drake 
(1998) observed a negative effect on SOC from increased $\mathrm{CO}_{2}$ in marsh soils.

Interestingly, $\mathrm{CO}_{2}$ fertilization of the atmosphere may cause a resulting increase of $\mathrm{O}_{2}$ release into the rhizosphere (Harrison et al., 1993; Ringelberg et al., 1997). For these reasons, increased SOC inputs from NPP as a result of increasing temperature and atmospheric $\mathrm{CO}_{2}$ concentrations may be out-paced by increasing soil respiration (Ball and Drake, 1998; Schlesinger and Mitchell, 1987). Schlesinger $(1990,1995)$ notes that less than 1 percent of annual NPP is stored in soils, and that forest management strategies for increasing this amount significantly are tenuous. Oechel and Vourlitis (1995) note disturbing evidence that some arctic soils have already changed from being net sinks to net sources of $\mathrm{CO}_{2}$ as a result of a warming trend. Nonetheless, the biogeochemical scenario of SOC dynamics is very complex, and regional opportunities to enhance C sequestration may exist (Johnson and Kern, 1991). There is some evidence that increased $\mathrm{CO}_{2}$ can lead to greater fine root biomass and turnover (Norby et al., 1992), which presumably could increase $\mathrm{C}$ sequestration in soil.

\section{THE INTERRELATIONSHIP OF SOIL ORGANIC CARBON AND FERTILITY}

Forest biomass and soil characteristics are interrelated, primarily via the moisture and fertility limitations of soil, and the SOM generated from biomass. These interacting phenomena are perhaps the major manageable aspects of forest productivity, (and thus $\mathrm{C}$ sequestration), (Kimmins, 1996). Root exudates and soil biota perform critical functions to catalyze geochemical dissolution and chelation of compounds for movement to or from the rhizosphere. The quantity and chemical characteristics of detritus and root mortality inputs to the soil determine a principle portion of forest nutrient cycling (Johnson, 1995). 
Annual inputs of litterfall are commonly in excess of $3 \mathrm{Mg} \mathrm{ha}^{-1}$ on eastern deciduous forest soils (Table 2.1) The rate at which they are decomposed and their nutrients mineralized are a function of the soil environment, the decomposing population, and the substrate quality (Swift et al., 1979; Meentemeyer, 1978). As described above, substrate quality and decomposition parameters are influenced by site, successional stage, and species. Generally, the $\mathrm{N}$ and lignin content of the detritus - largely a function of species and age, are the limiting factors of decomposition at a given site (Melillo et al., 1982). Lignification may be an effective nutrient retention strategy to slow leaching losses from sites with harsh environments. It is likely that the fertility of the soil environment affects the amounts and kinds of biomass inputs. It is known that similar temperate, udic soils with north aspects generally are less weathered and higher in SOC than on south aspects (Buol et al., 1997). It appears that greater productivity on north aspects is related more to energy dynamics than to soil mineral status (e.g. Hicks and Frank, 1984; Hicks et al., 1992 ). Hicks and Frank (1984) and Mudrick et al. (1994) observed higher lignin content and lower fertility in soils on south aspects than on north aspects in a forested West Virginia watershed. Leaching was also less from south-oriented watersheds (Hicks et al., 1992).

As a stand ages, woody debris comprises an increasing amount of detritus, and C:element and lignin:element ratios increase (Vitousek et al., 1988). In hardwood forests, by the time of harvest, usually many decades of litter-fall have passed, and storage of nutrients in SOM (especially including forest floor) has reached an equilibrium for that rotation. In high acidity/low fertility soils, SOC phenomena are of particular significance to soil 
properties including CEC, cation retention, and Al activity (Erich and Trusty, 1997; Hue et al., 1986; Moody et al., 1997; Wolt, 1994). As noted by Dyck and Cole (1994), and Henderson (1995), soils most dependent on organic matter for fertility are those most at risk of productivity decline. This is particularly pertinent for areas with high atmospheric deposition of anions and acidity, such as West Virginia (Adams et al., 1995, 1997). If fertility limitations to vegetation can be mitigated, $\mathrm{C}$ assimilation and subsequent sequestration in forests and soils may increase (Benemann, 1992).

Thus, for modeling the global $\mathrm{C}$ cycle and for managing forest ecosystems with objectives that include $\mathrm{C}$ sequestration and sustainable biomass productivity, it is necessary to have an accurate inventory of SOC pools as they relate to regional forest ecosystems. It is further desirable to identify and characterize relationships between SOC amounts and distribution and aspects of soil fertility that are pertinent to ecosystem productivity.

\section{FOREST BIOMASS}

Forest biomass production, distribution, and accumulation constitute a very important part of the C cycle. Oven-dry forest biomass is about 50 percent carbon (Birdsey, 1992 a,b; Brown and Lugo, 1982; Grigal and Ohman, 1992). Regional and global models have been developed for biomass estimation, using forest stand volume inventories (Brown et al., 1999; Brown and Schroeder, 1999; Brown et al., 1997; Birdsey, 1992b; Schroeder et al., 1997; Turner et al., 1995), and remote sensing (Hall et al., 1995; Wu and Strahler, 1994). Forests in the northeast constitute the largest regional $\mathrm{C}$ sink in the coterminous 


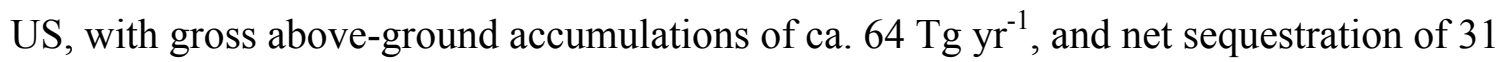

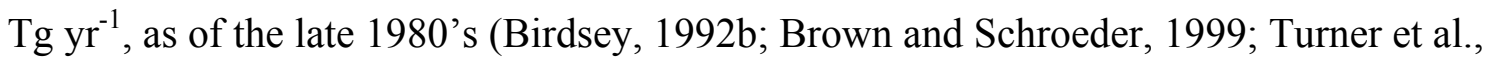
1995). The difference between gross and net values is attributable primarily to harvest removals. Brown and Schroeder (1999) report gross annual biomass accumulations averaging 5.2 and 4.9 $\mathrm{Mg} \mathrm{ha}^{-1}$ for hardwood and softwood forests, respectively. They suspect that root and soil $\mathrm{C}$ are also increasing, given that much of the region's forests are in some state of recovery.

In the eastern US, the Appalachian mountains have the highest biomass densities for hardwood forests (Brown et al., 1999). For West Virginia, where forest types and degree of maturation vary considerably, Brown et al. (1999) estimate total forest biomass to average from 121 to $220 \mathrm{Mg} \mathrm{ha}^{-1}$, with about 180 to $220 \mathrm{Mg} \mathrm{ha}^{-1}$ in the area of this study. Contrastingly, Tajchman et al. (1996) reported an 85-year-old experimental forest near Parsons, West Virginia to have above-ground woody biomass stocks ranging from 235 to $349 \mathrm{Mg} \mathrm{ha}^{-1}$. The striking difference between the forest inventory-generated estimates of Brown et al. (1999) and the measurements of Tajchman et al. (1996) is presumably a result of a the relative maturity of the measured forest. The estimates of Brown et al. (1999) are derived from USDA forest inventory data, which come from forests in varying stages of development.

The amount of forest biomass on a site is a function of the species, stand development stage (age), and stocking rate (i.e. basal area) (Vitousek et al., 1988). As forests mature, the relative proportion of biomass in structural material increases (Vitousek et al., 1988). 
Despite the higher leaf area index of evergreen forests (Vitousek, 1982, Rosenberg et al., 1983), deciduous forests generally have higher areal biomass stocks (Brown et al., 1999) - owing largely to the greater density of deciduous woody material. Biomass allocation is variable among forests and trees, but estimates for relatively mature temperate deciduous stands summarized by Schlesinger (1997) attribute $63 \%$ to boles, $20 \%$ to roots, $16 \%$ to branches, and $1 \%$ to leaves. For deciduous and evergreen forests studied in several Maine counties, Wharton and Griffith (1998) found that non-timber biomass (salvable dead trees, saplings, seedlings, and shrubs) accounted for about $22 \%$ of total site dry vegetative biomass. Among the "growing stock" timber (30.5 cm diameter stump to 10.2 cm diameter top), non-merchantable biomass (roots, stump, branches, foliage) accounted for about $36 \%$ of timber dry biomass, excluding cull trees.

Site factors affect forest biomass accumulation primarily via their influence on radiation, temperature, moisture, and nutrition. Climatic and soil effects from aspect are important determinants of biomass accumulation on sites in Appalachia. Tajchman et al. (1996) and Hicks and Frank (1984) documented highest above-ground biomass accumulation on north- and east-oriented aspects in West Virginia. Tajchman and Wiant (1983) found that both site index and biomass accumulation were least on west aspects, and that slope affected site index negatively on south and west aspects, and positively on north aspects. Coinciding with higher biomass in the above studies were increasing soil fertility attributes such as exchangeable bases and $\mathrm{pH}$.

The cumulative biomass of herbaceous, seedling, sapling, and shrub components can be significant in forest ecosystems. Regression equations for above- and below-ground 
biomass for a variety of Eastern US species have been developed (e.g. Birdsey, 1992b; Wharton and Griffith, 1998; Young et al., 1980). These equations are developed from a number of studies that related total dry biomass to stand volume, using estimation techniques based on diameter and/or height of trees and shrubs from seedling-stage to maturity.

Dead woody debris (DWD) can comprise a significant portion of forest biomass C (Harmon et al., 1993), resulting either from episodic events or normal mortality over time. Spetich et al. (1999) reported declining ratios of DWD:live tree volumes from stand ages of 10 to 70 years, followed by increasing ratios from 70 to 200 years in the Midwest. Dead woody debris carbon continues to accumulate after forest stands are "mature" or into "old-growth" stage (Harmon et al., 1986). Thus, there is a substantial lag period after harvest or catastrophic events such as blow-down before DWD is decomposed. It is normally early or late in forest succession when the portion of site biomass C in DWD is substantial. With increasing stand age C:element and lignin:element ratios increase (Vitousek et al., 1988). Accumulation of DWD is a function of an increase in the deposition of more lignified debris, and also the slower decomposition that results as debris size increases (Harmon et al., 1993). In an old-growth mesophytic forest on the Cumberland Plateau of southeastern Kentucky, Muller and Liu (1991) found coarse woody debris to be about $22 \mathrm{Mg} \mathrm{ha}^{-1}$. 


\section{REFERENCES}

Adams, M.B., T.R. Angradi, and J.N. Kochenderfer. 1997. Stream water and soil solution responses to 5 years of nitrogen and sulfur additions at the Fernow Experimental Forest, West Virginia. For. Ecol. Manage. 95:79-91.

Adams, M.B., J.N. Kochenderfer, T.R. Angradi, and P.J. Edwards. 1995. Nutrient budgets of two watersheds on the Fernow Experimental Forest. p. 119-130. In Gottschalk, K.W. and S.L.C. Fosbroke (ed.) Proc. 10th Central hardwood forest conference. West Virginia University. Morgantown, West Virginia.

Alban, D.H., and J. Pastor. 1993. Decomposition of aspen, spruce, and pine boles on two sites in Minnesota. Can. J. For. Res. 23:1744-1749.

Andrews, J.A., K.G. Harrison, R. Matamala, and W.H. Schlesinger. 1999. Separation of root respiration from total soil respiration using carbon-13 labeling during free-air carbon dioxide enrichment (FACE). Soil Sci. Soc. Am. J. 63: 1429-1435.

Arnold, R.W. 1995. The role of soil survey in obtaining a global carbon budget. p. 257263. In R. Lal et al. (ed.) Soils and global change. CRC Press, Boca Raton, FL.

Ball, A.S., and B.G. Drake. 1998. Stimulation of soil respiration by carbon dioxide enrichment of marsh vegetation. Soil Biol. Biochem. 30:1203-1205. 
Benemann, J.R. 1992. The use of iron and other trace element fertilizers in mitigating global warming. J. Plant Nutr. 15(10):2277-2313.

Birdsey, R.A.(a) 1992. Changes in forest carbon storage from increasing forest area and timber growth. p. 23 - 39. In Sampson, R.N. and D. Hair (ed.) Forests and global change. Vol. 1: Opportunities for increasing forest cover. American Forests, Washington DC.

Birdsey, R.A.(b) 1992. Carbon storage and accumulation in United States forest ecosystems. USDA Forest Service GTR WO-59.

Blake, G.R., and K.H. Hartge. 1986. Bulk density. p. 363-375. In A. Klute (ed.) Methods of soil analysis. Part 1. $2^{\text {nd }}$ ed Agron. Monogr. 9. ASA and SSSA, Madison, WI.

Bliss, N.B., S.W. Waltman, and G.W. Peterson. 1995. p. 275 -295 In R. Lal et al. (ed.) Soils and global change. CRC Press, Boca Raton, FL.

Bouman, A.F., and R. Leemans. 1995. The role of forest soils in the global carbon cycle. p. 503-525. In W.W. McFee and J.M. Kelly (ed.) Carbon forms and functions in forest soils. SSSA, Madison, WI. 
Brady, N.C., and R.R. Weil. 1999. The nature and properties of soils. Twelfth ed. Prentice-Hall, Upper Saddle River, NJ. 881pp.

Browne, B. 1995. Toward a new theory of podzolization. p. 253-274. In W.W. McFee and J.M. Kelly (ed.) Carbon forms and functions in forest soils. SSSA, Madison, WI.

Brown, S.L., and A.E. Lugo. 1982. The storage and production of organic matter in tropical forests and their role in the global carbon cycle. Biotropica 14:161-187.

Brown, S.L., and P.E. Schroeder. 1999. Spatial patterns of aboveground production and mortality of woody biomass for eastern U.S. forests. Ecol. Appl. 9:968-980.

Brown, S.L., P. Schroeder, and J.S. Kern. 1999. Spatial distribution of biomass in forests of the eastern USA. For. Ecol. Mngmt. 123:81-90.

Brown, S.L., P. Schroeder, and R. Birdsey. 1997. Aboveground biomass distribution of US eastern hardwood forests and the use of large trees as an indicator of forest development. For. Ecol. Mngmt. 96:37-47.

Buol, S.D., F.D. Hole, and R.J. McCraken. 1997. Soil genesis and classification. $4^{\text {th }}$ edition. Iowa St. Univ. Press. Ames, IA. 
Chandler, R.F. Jr. 1994. The amount and mineral nutrient content of freshly fallen leaf litter in the hardwood forests of central New York. J. Amer. Soc. Agron. 33: 859-871.

Davidson, E.A., and P.A. Lefebvre. 1993. Estimating regional carbon stocks and spatially covarying edaphic factors using soil maps at three scales. Biogeochem. 22:107-131.

Delp, C.H. 1998. Soil Survey of Webster County, West Virginia. USDA-Natural Resources Conservation Service, Washington, DC

Duxbury, J. 1991. Functional carbon pools. In Johnson, M.G., and J.S. Kern (ed.) Sequestering carbon in soils: a workshop to explore the potential for mitigating global climate change. Environmental Protection Agengy. Corvallis, Oregon. 85pp.

Dyck, W.J., and D.W. Cole. 1994. Strategies for determining consequences of harvesting and associated practices on long-term site productivity. p.13-40. In Dyck, W.J., D.W. Cole, and N.B. Comerford (ed.) Impacts of forest harvesting on long-term site productivity. Chapman and Hall, London.

Entry, J.A., C.L. Rose, and K. Cromack. 1992. Microbial biomass and nutrient concentrations in hyphal mats of the ectomycorrhizal fungus of Hysterangium setchellii in a coniferous forest soil. Soil Biol. Biochem. 24:447-453. 
Erich, S.E., and G.M. Trusty. 1997. Chemical characterization of dissolved organic matter released by limed and unlimed forest soil horizons. Can J. Soil Sci. 77:4045-413.

Eswaran, H. 1979. Micromorphology of ultisols and alfisols with low activity clays. p. 53 - 76. In Proceedings: International soil classification workshop, 1978.

Eswaran, H., I. Van den Berg, P.Reich, and J. Kimble. 1995. Global soil carbon resources. p. 27-43. In R. Lal et al. (ed.) Soils and global change. CRC Press, Boca Raton, FL.

Eswaran, H., E. VanDen Berg, and P. Reich. 1993. Organic carbon in soils of the world. Soil Sci. Soc. Am. J. 57:192-194.

Fahey, T.J., J.W. Hughes, M. Pu, and M.A. Arthur. 1988. Root decomposition and nutrient flux following whole-tree harvest of northern hardwood forest. Forest Science 34(3):744-768.

Fisher, R.F. 1995. Soil organic matter: clue or conundrum? In W.W. McFee and J.M. Kelly (ed.) Carbon forms and functions in forest soils. SSSA, Madison, WI.

Flegel, D.G. 1999. Soil Survey of Pocahontas County, West Virginia. USDA-Natural Resources Conservation Service, Washington, DC. 
Fogel, R. 1980. Mycorrhizae and nutrient cycling in natural forest ecosystems. New Phytology 86:199-212.

Fox, T.R. 1995. The influence of low-molecular-weight organic acids on properties and processes in forest soils p. 43-61. In W.W. McFee and J.M. Kelly (ed.) Carbon Forms and Functions in Forest Soils SSSA, Madison, WI.

Franzmeier, D.P., G.D. Lemme, and R.J. Miles. 1985. Organic carbon in soils of North Central United States. Soil Sci. Soc. Am. J. 49:702-708.

Griffiths, R.P., J.E. Baham, and B.A. Caldwell. 1994. Soil solution chemistry of ectomycorrhizal mats in forest soil. Soil Biol. and Biochem. 26(3):331-337.

Grigal, and L.F. Ohmann. 1992. Carbon storage in upland forests of the lake states. Soil Sci. Soc. Am. J. 56: 935-943.

Grossman, R.B. 1991. Work group 1: Organic matter. p. 72-77. In Waltman et al. (ed) Proceedings of the first soil genesis modelling conference 13-15 Aug. 1991. USDANatural Resources Conservation Service, National Soil Survey Center, Lincoln, NE

Hall, F.G., Y.E. Shimabukuro, and K.F. Huemmrich. 1995. Remote sensing of forest biophysical structure using mixture decomposition and geometric reflectance models. Ecol. Appl. 5:993-1013. 
Harden, J.W., E.T. Sundquist, R.F. Stallard, and R.K. Mark. 1992. Dynamics of soil carbon during deglaciation of the Laurentide ice sheet. Science 258:1921-1924.

Harmon, M.E., S. Brown, and S.T. Gower. 1993. Consequences of tree mortality to the global carbon cycle. p. 167-177 In Vinson, T.S., and T.P. Kolchugina, (ed.) Carbon cycling in boreal forest and sub-arctic ecosystems: biospheric responses and feedbacks to global climate change. EPA/600/R-93/084, USEPA, Corvallis, Oregon.

Harmon, M.E., J.F. Franklin, F.G. Swanson, P. Sollins, S.V. Gregory, J.D. Lattin, N.H. Anderson, S.P. Cline, N.G. Aumen, J.R. Sedell, G.W. Lienkaemper, K. Cromack Jr., and K.W. Cummins. 1986. Ecology of coarse woody debris in temperate ecosystems. Advances in Ecological Research 15:133-302.

Harris, W.F., R.S. Kinerson, Jr., and N.T. Edwards. 1977. Comparison of belowground biomass of natural deciduous forest and loblolly pine plantations. Pedobiologia 17:369381.

Harrison, K., W. Broecker, and G. Bonani. 1993. A strategy for estimating the impact of $\mathrm{CO}_{2}$ fertilization on soil carbon storage. Global Biogeochemical Cycles. Washington, DC: American Geophysical Union 7(1):69-80. 
Henderson, G.S. 1995. Soil organic matter: A link between forest management and productivity. p. 419-435. In W.W. McFee and J.M. Kelly (ed.) Carbon forms and functions in forest soils. SSSA, Madison, WI.

Hicks, R.R.Jr., and P.S. Frank. 1984. Relationship of aspect to soil nutrients, species importance, and biomass in a forested watershed in West Virginia. For. Ecol. and Mngt. 8:281-291.

Hicks, R.R., D. Mudrick, and E. Townsend. 1992. Nutrient fluxes for two small watersheds: seven-year results from the West Virginia University Forest. West Virginia University Agricultural and Forestry Experiment Station Bulletin 707. Morgantown, West Virginia.

Homann, P.S., P. Sollins, H.N. Chappell, and A.G. Stangenberger. 1995. Soil organic carbon in a mountainous, forested region: Relation to site characteristics. Soil Sci. Soc. Am. J. 59:1468-1475.

Horwath, W.R. 1993. The dynamics of carbon, nitrogen, and soil organic matter in a Populus plantation. Ph.D. Thesis. Michigan State University, East Lansing.

Houghton, J. T., L. G. M. Filho, B. A. Callander, N. Harris, A. Kattenberg, and K. Maskell. 1996. Climate Change 1995: The science of climate change, intergovernmental panel on climate change. Cambridge University Press, Cambridge, GB. 572 pp. 
Hue, N.V., G.R. Craddock, and F. Adams. 1986. Effect of organic acids on aluminum toxicity in subsoils. Soil Sci. Soc. Am. J. 50:28-34.

Huntington, T.G., C.E. Johnson, A.H. Johnson, T.G. Siccama, and D.F. Ryan. 1989. Carbon, organic mater, and bulk density relationships in a forested spodosol. Soil Sci. 148(5):380-386.

Illmer, P., and F. Schinner. 1992. Solubilization of inorganic phosphates by microorganisms isolated from forest soils. Soil Biol. and Biochem. 24(4):389-395.

Jenny, H. 1980. The soil resource. Springer-Verlag, New York.

Joergensen, R. 1995. The fumigation extraction method. p. 375-396. In Alef, K., and P. Nannipieri (ed.) Methods in applied soil microbiology and biochemistry. Academic Press, London.

Johnson, D.W. 1995. Role of carbon in the cycling of other nutrients in forested ecosystems. p. 299-328. In W.W. McFee and J.M. Kelly (ed.) Carbon forms and functions in forest soils. SSSA, Madison, WI. 
Johnson, M.G., and J.S. Kern. 1991. Sequestering carbon in soils: A workshop to explore the potential for mitigating global climate change. USEPA Rep. 600/3-91/031. Environ. Res. Lab., Corvallis, Oregon.

Johnson, J.E. D.W. Smith, and J.A. Burger. 1985. Effects on the forest floor of wholetree harvesting in an Appalachian oak forest. Am. Midland Naturalist. 114(1): 51-61.

Joslin, J.D., and G.S. Henderson. 1987. Organic matter and nutrients associated with fine root turnover in a white oak stand. For. Sci. 33(2): 330-346.

Kaczmarek, D.J., K.S. Rodkey, R.T. Reber, P.E. Pope, and F. Ponder, Jr. 1995. Carbon and nitrogen pools in oak-hickory forests of varying productivity. p. 79-93. In Gottschalk, K.W. and S.L.C. Fosbroke (ed.) Central Hardwood Forest Conference. Morgantown, West Virginia.

Kelly, J.M. and J.D. Joslin. 1989. Mass and chemical composition of roots in two secondgrowth forests in eastern Tennessee. For. Ecol. Manage. 27:87-92.

Kern, J.S. 1994. Spatial patterns of soil organic carbon distribution in the contiguous United States. Soil Sci. Soc. Am. J. 58: 439-455.

Kimmins, J.P. 1996. Importance of soil and role of ecosystem disturbance for sustained productivity of cool temperate and boreal forests. Soil Sci. Soc. Am. J. 60:1643-1654. 
Kirschbaum, M.U.F. 1995. The temperature dependence of soil organic matter decomposition, and the effect of global warming on soil organic $\mathrm{C}$ storage. Soil Biol. Biochem. 27(6): 753-760.

Lal, R., J. Kimble, E. Levine, and C. Whitman. 1995. World soils and greenhouse effect: An overview. p. 1-7. In R. Lal et al. (ed.) Soils and global change. CRC Press, Boca Raton, FL.

Lloyd, J. and J.A. Taylor. 1994. On the temperature dependence of soil respiration. Functional Ecology 8:315-323.

Marx, D.H. 1978. Mycorrhizae and feeder root diseases. p. 351-382. In Marks, G.C., and T.T.Kazlowski (ed.) Ectomycorrhizae: Their ecology and physiology. Academic Press, New York.

McColl, J.G., and N. Gressel. 1995. Forest soil organic matter: characterization and modern methods of analysis. In W.W. McFee and J.M. Kelly (ed.) Carbon forms and functions in forest soils. SSSA, Madison, WI.

Meentemeyer, V. 1978. Macroclimate and lignin control of litter decomposition rates. Ecology 59(3):465-472. 
Melillo, J.M., J.D. Aber, A.E. Linkins, A. Ricca, B. Fry, and K.J. Nadelhoffer. 1989. Carbon and nitrogen dynamics along the decay continuum: plant litter to soil organic matter. Plant and Soil 1115:189-198.

Melillo, J.M., J.D. Aber, and J.F. Muratore. 1982. Nitrogen and lignin control of hardwood leaf litter decomposition. Ecology 63:621-626.

Meyer, F.H. 1974. Physiology of mycorrhizae. Annual Review of Plant Physiology 25:567-586.

Mineo, L. J.L. Wasserman, S.K.Majumdar, C. VanTyne, and R. Zelnick. 1987. Calcium and phosphorus content of oak ectomycorrhizae from mull and mor forests of northeastern Pennsylvania. Gen.Tech. Rep. SE USDA For. Serv. SE-46:60-65.

Moody, P.W., S.A. Yo, and R.L. Aitken. 1997. Soil organic carbon, permanganate fractions, and the chemical properties of acidic soils. Aust. J. Soil Res. 35:1301-1308.

Moore, T. 1997. Dissolved organic carbon: Sources, sinks, and fluxes and the role in the soil carbon cycle. p. 281-292. In R. Lal et al. (ed.) Soil processes and the carbon cycle. Advances in Soil Science. CRC Press, Boca Raton, FL. 
Mudrick, D.A., M. Hoosein, R.R. Hicks Jr., and E.C. Townsend. 1994. Decomposition of leaf litter in an Appalachian forest: effects of leaf species, aspect, slope position, and time. For. Ecol. Mangmt. 68:231-250.

Muller, R.N., and Y. Liu. 1991. Coarse woody debris in an old-growth deciduous forest on the Cumberland Plateau, southeastern Kentucky. Can. J. For. Res. 21:1567-1572.

Murthy, R., P.M. Dougherty, S.J. Zarnoch, and H.L. Allen. 1996. Effects of carbon dioxide, fertilization, and irrigation on photosynthetic capacity of loblolly pine trees. Tree Physiology 16:537-546.

Nadelhoffer, K.J., J.D. Aber, and J.M. Melillo. 1985. Fine roots, net primary production, and soil nitrogen availability: a new hypothesis. Ecology 66(4):1377-1390.

Norby, R.J., C.A. Gunderson, S.D. Wullschleger, E.G. O'Neill, and M.K. McCracken. 1992. Productivity and compensatory responses of yellow-poplar trees in elevated $\mathrm{CO}_{2}$. Nature 357:322-324.

Oechel, W.C., and G.L. Vourlitis. 1995. Effect of global change on carbon storage in cold soils. p. 17-129. In R. Lal et al. (ed.) Soils and global change. CRC Press, Boca Raton, FL. 
Paul, E.A., and F.E. Clark. 1996. Soil Biology and Biochemistry. Academic Press, San Diego, CA. 340 p.

Post, W.M., W.R. Emanuel, P.J. Zinke, and A.G. Stangenberger. 1982. Soil carbon pools and world life zones. Nature 298:156-159.

Post, W.M., T.H. Peng, W.R. Emanuel, A.W. King, V.H. Dale, and D.L. De Angelis. 1990. The global carbon cycle. Am. Sci. 78:310-326.

Raich, J.W. and W.H. Schlesinger. 1992. The global carbon dioxide flux in soil respiration and in relationship to vegetation and climate. Tellus 44B:81-99.

Ringelberg, D. B., J.O. Stair, J. Almeida, R.J. Norby, E.G. O’Neill, and D.C. White. 1997. Consequences of rising atmospheric carbon dioxide levels for the below-ground microbiota associated with white oak. J. Environ. Qual. 26:495-503.

Rodkey, K.S., D.J. Kaczmarek, and P.E. Pope. 1995. The distribution of nitrogen and phosphorus in forest floor layers of oak-hickory forests of varying productivity. p. 94 108. In Gottschalk, K.W. and SL.C. Fosbroke (ed) Proc: $10^{\text {th }}$ central hardwoods forest conference. West Virginia University. Morgantown, West Virginia.

Rosenberg, N.J., B.L. Blad, and S.B. Verma. 1983. Microclimate: The Biological Environment. Wiley and Sons, New York. 
Schlesinger, W.H. 1997. Biogeochemistry: An analysis of global change. $2^{\text {nd }}$ ed. Academic Press, San Diego.

Schlesinger, W.H. 1995. An overview of the carbon cycle. p. 9-25. In R. Lal et al. (ed.) Soils and global change. CRC Press, Boca Raton, FL.

Schlesinger, W.H. 1990. Evidence from chronosequence studies for a low carbon-storage potential of soils. Nature 348:232-234.

Schlesinger, W.H.1977. Carbon balance in terrestrial detritus. Annu. Rev. Ecol. System. 8:51-81.

Schlesinger, W.H., and J.F.B. Mitchell. 1987. Climate model simulations of the equilibrium climatic response to increased carbon dioxide. Rev. Geophys. 25:760-798.

Schroeder, P., S.L. Brown, L. Mo, R. Birdsey, C. Cieszewski. 1997. Biomass estimation for temperate broadleaf forests of the US using forest inventory data. Forest Sci. 43: 424434.

Snyder, K.E., and S.A.L. Pilgrim. 1985. Sharper focus on forest floor horizons. Soil Surv. Horizons 26(3):9-15. 
Spetich, M.A., S.R. Shifley, and G.R. Parker. 1999. Regional distribution and dynamics of coarse woody debris in Midwestern old-growth forests. For. Sci. 45(2):302-313.

Stevenson, F.J. 1994. Humus chemistry. 2nd edition John Wiley and Sons, New York.

Swift, M.J., O.W. Heal, and J.M. Anderson. 1979. Decomposition in terrestrial ecosystems. Univ. of California Press, Berkeley.

Tajchman, S.J., R. Benyon, L. Bren, J. Kochenderfer, and C. Pan. 1996. On spatial variability of above-ground biomass. Biomass and Bioenergy 11(5):383-386.

Tajchman, S.J., and H.V. Wiant. 1983. Topography and biomass characteristics of a forested catchment in the northern Appalachians. For. Ecol. Mngt. 5:55-69.

Turner, D.F., G.J. Koerper, M.E. Harmon, and J.J. Lee. 1995. A carbon budget for forests of the coterminous United States. Ecol. Appl. 5 (2):421-436.

Vance, E.D., Brooks, P. C., and D. S. Jenkinson. 1987 (a). Microbial biomass measurements in forest soils: determination of the Kc values and tests of hypotheses to explain the failure of the chloroform fumigation-incubation method in acid soils. Soil Biol. and Biochem. 19 (6):689-696. 
Vance, E.D., Brooks, P. C., and D. S. Jenkinson. 1987 (b). Microbial biomass

measurements in forest soils: the use of the chloroform fumigation-incubation method in strongly acid soils. Soil Biol. and Biochem. 19 (6):697-702.

Vance, E.D., Brooks, P. C., and D. S. Jenkinson. 1987 (c). An extraction method for measuring soil microbial biomass carbon. Soil Biol. and Biochem. 19 (6):703-707.

Vitousek, P.M. 1982. Nutrient cycling and nutrient use efficiency. Am. Naturalist 119:553-572.

Vitousek, P.M., T. Fahey, D.W. Johnson, and M.J. Swift. 1988. Element interactions in forest ecosystems: succession, allometry and input-output budgets. Biogeochemistry 5:734.

Walker, R.F., and S. B. McLaughlin. 1991. Growth and root system development of white oak and loblolly pine as affected by simulated acidic precipitation and ectomycorrhizal inoculation. For. Ecol. and Mngmt. 46:123-133.

Wharton, E.H., and D.M. Griffith. 1998. Estimating total forest biomass in Maine, 1995. 50 p. USFS Res. Bull. NE-142. Northeastern Res. Sta., Radnor, PA.

Wiant, H.V., Jr. 1967. Influence of temperature on the rate of soil respiration. J. Forestry $65: 489-490$. 
Winkler, J.P., R.S. Cherry, and W.H. Schlesinger. 1996. The $\mathrm{Q}_{10}$ relationship of microbial respiration in a temperate forest soil. Soil Biol. Biochem. 28: 1027-1072.

Wolt, J. 1994. Soil Solution Chemistry: Applications to Environmental Science and Agriculture, Wiley and Sons, New York.

Wu, Y. and A.H. Strahler. 1994. Remote estimation of crown size, stand density, and biomass on the Oregon transect. Ecol. Appl. 4:299-312.

Young, H.E., J.H. Ribe, and K. Wainwright. 1980. Weight tables for tree and shrub species in Maine. 84p. Misc. Rep. 230. Univ. of Maine, Life Sci. Agr. Exp. Sta., Orono, ME. 


\section{CHAPTER THREE}

\section{MATERIALS AND METHODS}

\section{PROJECT HISTORY}

In the spring of 1995, a cooperative agreement between the Monongahela National Forest (MNF) and the USDA-Natural Resources Conservation Service (NRCS), in conjunction with the West Virginia Agricultural and Forestry Experiment Station, was established. The purpose was to perform preliminary soil mapping on 4,050 ha of high elevation (frigid) areas in the MNF, with a primary purpose of a frigid soil legend establishment to be accompanied by a SOC study to be funded and conducted by WVU and NRCS.

The area of study was rather broad, with mapping set up initially as 15 405-ha (1000 acre) "test mapping" blocks, which were narrowed to 10 based on elevation and USFS ownership. These areas occur in Randolph and Tucker Counties, on lower Pennsylvanian geologic strata. The mapping was completed prior to sampling during the summer of 1995, and the (currently) unpublished copies of the soil maps are maintained by the NRCS (Morgantown, West Virginia) and the MNF (Elkins, West Virginia). From this mapping, in conjunction with consideration of other areas of frigid soils in the state, the most extensive series were selected for sampling. Sampling was conducted primarily in the area of the preliminary mapping, with 2 pedons (Gauley series) sampled in Pocahontas County, West Virginia. 


\section{Study Area and Soil Series}

The study area sampled for this work is located in the Monongahela National Forest, in Major Land Resource Area 127 (USDA, 1981) on the Allegheny Plateau of West Virginia, USA. The Allegheny Plateau in this region is broadly but deeply dissected. The ridges, upper coves, and side-slopes are the landforms studied herein, although larger side-slope, foot-slope, and varying levels of alluvium occur below the elevations in this study. The Allegheny Plateau gradually gains elevation from west to east across West Virginia, until its termination at the Allegheny Front at the eastern edge of MLRA 127. The study area is on the eastern (higher) portion of the Plateau in West Virginia. The elevations of the study sites range from about 1100 to $1300 \mathrm{~m}$. Mean annual precipitation ranges from 1300 to $1400 \mathrm{~mm}$ throughout the sampled study region. Most precipitation falls as rain, well distributed throughout the year (Flegel, 1999; Losche and Beverage, 1967). Snow cover is seldom persistent for more than a few weeks.

Four pedons from map units of the following soil series and correlated classification were sampled: Mandy (loamy-skeletal, mixed, frigid Typic Dystrochrepts), Snowdog (fine-loamy, mixed, frigid Aquic Fragiochrepts), Gauley (loamy-skeletal, siliceous, frigid Typic Haplorthods). It should be noted that, to date, the above series have not been reclassified to include clay activity class, this study constitutes the first sampling of these soils and they will subsequently be reclassified. A tentative series that will be referred to as moderately well drained (MWD) Gauley was sampled. The classification of the pedons of this series is tentatively presented as loamy-skeletal, siliceous, superactive, 
frigid Typic Epiaquods. The established series above include the most extensive frigid series in this region, with a combined correlated acreage (not including MWD Gauley) in excess of 100,000 ha (USDA-NRCS National Soil Information System (NASIS) database, 12/99). The extent of MWD Gauley is estimated to be in excess of 1000 ha (based on the mapping for this work). Additionally, a soil of unknown extent was sampled at only 2 locations. This soil is not an established series, and is tentatively named Blackwater (loamy-skeletal, siliceous, semiactive, frigid Fragiaquic Dystrudepts). The data regarding this series are presented - but not utilized for comparisons. I have chosen not to utilize it for comparisons because it is of unknown extent, our knowledge is limited regarding its characteristics range, and having only 2 pedons would render most interpretation equivocal.

The parent materials on these montane landscapes are Pennsylvanian-aged sandstones and shales, with some coal layers (Price, 1968; Reger, 1923, 1931). These strata are generally very acid, and many of the sandstones in the Randolph and Tucker County area are noted for their resistance to weathering, with $\mathrm{SiO}_{2}$ comprising $97 \%$ or more by weight (Reger, 1923, 1931). The regional dip of these sediments is slight, to the northwest. In the area of this study, some anticlinal and synclinal activity is expressed, though bedrock appeared to be nearly horizontal where observable at the pedon sample locations. Most notably are some sites within the generally synclinal Otter Creek and Dolly Sods Wilderness Areas, and adjacent to the anticlinal Canaan Valley. 
The series are well drained or moderately-well drained, and were sampled on landforms and slopes most typical of their occurrence (Table 3.1). Mandy was sampled on slopes ranging from 35 to $50 \%$, and Snowdog was sampled on slopes ranging from 15 to $35 \%$. Two pedons of each of these series were sampled from both north and south orientations to account for the varying effects of aspect on soil properties and biomass characteristics (Tajchman and Wiant, 1983; Tajchman et al., 1996; Hicks and Frank, 1984). Blackwater, Gauley, and MWD Gauley occur primarily on slopes of less than $8 \%$, and were sampled accordingly. In contrast to the randomness normally required for description of populations of soils, this study focused on characterization of pedons selected as being representative of mapped soil types. The strategy here was to sample typical examples for mapped series for which there is a central concept of site and morphological expressions that are of significance to forest growth (among other things). In order to give a more regional representation to the data, no two pedons were sampled in the same soil map unit delineation.

The sites were selected to be consistent in having relatively undisturbed and reasonably well stocked forests to reduce any obvious sources of variability resulting from differences in forest age or disturbance regime. So far as we were able to ascertain, no sites had been harvested or suffered significant soil disturbance in the last 40 years or more. 
Table 3.1. Depth, drainage, and typical landforms of the series.

$\begin{array}{llll}\text { Series } & \underline{\text { Depth class }} & \text { Drainage } & \text { Landform/parent material } \\ \text { Mandy } & 50-100 \mathrm{~cm} & \text { well } & \text { Side-slopes, ridge-tops, residuum. } \\ \text { Snowdog } & >2 \mathrm{~m} & \text { mod. well } & \text { Side-slopes, foot-slopes, colluvium. } \\ \text { Gauley } & 50-100 \mathrm{~cm} & \text { well } & \text { Ridge-tops, residuum. } \\ \text { MWD Gauley } & 50-100 \mathrm{~cm} & \text { mod. well } & \text { Ridge-tops, residuum. }\end{array}$

The region of this study is about $80 \%$ forested (DiGiovanni, 1990). The Mandy and Snowdog series support mixed northern hardwood forests usually dominated by red maple (Acer rubrum L.) or yellow birch (Betula alleghaniensis Britt.), with black cherry (Prunus serotina Ehrh.), red oak (Quercus rubra L.), and sugar maple (Acer saccharum Marsh.) on some sites. The Gauley and MWD Gauley sites are dominated by red spruce (Picea rubens Sarg.) or eastern hemlock (Tsuga canadensis L.), with a few red maple and yellow birch on some sites.

\section{Sampling}

The soils were sampled and above-ground biomass measurements were taken from July through early October 1995. At each site, a pit was hand-excavated for soil description and sampling. The soil pit became the plot center for biomass measurements (described below). Detailed pedon and site descriptions were recorded using the USDA-NRCS Pedon Description Program and are attached in Appendix A. Each pedon was 
individually classified following the receipt of laboratory data, and compared to the published classification of the series for which it was sampled.

The sampling scheme for these series was intended to address multiple objectives. Bulk sampling was performed with plastic gardening hand-spades to avoid contamination with heavy metal elements (for a separate study). Bulk sampling of the pedon face was performed from bottom to top of clean (picked and brushed) vertical pedon exposures. In addition to normal bulk sampling of subsoil and substratum horizons, forest floor $(\mathrm{O})$ and epipedon horizons were excavated from known surface areas $\left(0.25 \mathrm{~m}^{2}-1.0 \mathrm{~m}^{2}\right)$. These areas were delineated with the use of twine and nails. The purpose of this was to gain a more representative sample from the typically thin and variable forest floor horizons. Bulk density $(\mathrm{Db})$ was estimated using techniques that are discussed in detail below. All pedons were exposed and sampled to at least $150 \mathrm{~cm}$ or to bedrock, whichever was shallower. One pedon of Snowdog contained a carbolithic-influenced C horizon at 122 $\mathrm{cm}$; so SOC calculations for this work stopped at that depth. Soil organic carbon stocks for all other pedons are calculated to bedrock or Cr horizons, or $150 \mathrm{~cm}$, whichever is deeper.

\section{$\underline{\text { Rock Fragment Estimation }}$}

In rough, mountain terrain, the establishment of rock fragment volumes present a conundrum. The problem lies in the inadequacy of small area sampling in accounting for the great variability in rock fragments. On these sites, stone cover varies radically, often 
from 3 to 100 percent within $100 \mathrm{~m}$. If subsurface variation is even a fraction of surface variations, tens to hundreds of cubic meters of soil horizons would have to be extracted and sieved to address it (Erich and Trusty, 1997; Fernandez et al. 1993; Huntington et al. 1989). The time, energy, and disturbance that would have been necessary to attempt a rigorous sampling solution eliminated it as an option. This situation was dealt with in different ways for subsurface horizons vs. forest $\mathrm{O}$ horizons. Volumes of rock fragments in subsurface mineral horizons were visually estimated by experienced soil scientists from the area. Rock piles were avoided as impossible, and stone-free areas were avoided as atypical.

Rock fragment content of $\mathrm{O}$ horizons was estimated by establishing two perpendicular 30-m transects at each pedon site, where a tile spade was pushed down to the mineral soil layer every $30 \mathrm{~cm}$, and the "strikes" on rock fragments were recorded. The common (intersection) point of the transects was established on a line $288^{\circ} \mathrm{NW} 11.3 \mathrm{~m}$ from the sampled soil profile. One transect line proceeded due east $\left(90^{\circ}\right)$ and another due north $\left(0^{\circ}\right)$. The percentage of strikes was calculated, and subsequently multiplied by 0.6 because not all rock fragments occupy space in all $\mathrm{O}$ horizons. This factor is somewhat arbitrary, based upon field observations of rock fragments that reach an uppermost depth anywhere from above any $\mathrm{O}$ horizon to within any $\mathrm{O}$ horizon. It was felt that most rock fragments struck in the transect occupied space in something more than half of the $\mathrm{O}$ horizons. This is the rock fragment percentage used in all nutrient and $\mathrm{C}$ calculations. For nutrient content calculations, the undecomposed leaf litter layer was assumed to cover 70 $\%$ of the forest floor, allowing for uncovered areas occupied by tree boles, rocks, and 
fallen logs. These rather arbitrary procedures for forest floor rock fragment estimation and litter cover were necessary due to the rubbly nature of the sample sites.

\section{$\underline{\text { Bulk Density }}$}

The use of undisturbed soil clods is the standard soil survey technique for determining bulk density (National Soil Survey Laboratory Staff, 1996). However, bulk density estimation presents a problem for forest soil scientists (Manrique and Jones, 1991; Shipp and Matelski, 1965; Vincent and Chadwick, 1994.) In addition to the difficulties presented by rock fragments, the presence of very fine to very coarse roots, and very friable consistence (i.e. high SOM) makes clod excavation difficult or impossible from upper horizons.

The major impediment to clod excavation in subsoil and substrata is the presence of rocks, sometimes coincident with firm and brittle consistency. In this situation, clods would be most obtainable from either areas with fewer rock fragments, or less firm consistence. In the former situation, the bias may be negligible, being only a difference in the measurement error associated with rock content in clods. But clods taken from less firm or brittle areas would likely be less dense. Thus the error associated with clods here would be towards underestimation of horizon $\mathrm{Db}$, probably a small but potentially significant percentage of the true value. 
For all subsoil and substratum horizons, the clod method was used to determine $\mathrm{Db}$ (Blake and Hartge, 1986). The clod method was chosen over the core method primarily due to the high percentage of rock fragments in most horizons of the series. Where rocks prevented clod excavation, the $\mathrm{Db}$ value from an adjacent horizon most morphologically similar was substituted. This occurred in 6 horizons.

Where clods have been obtained from epipedon horizons, I submit that a strong bias exists for higher $\mathrm{Db}$ estimates. This is a result of essentially digging through large volumes of an unconsolidated horizon to finally obtain a clod with sufficient coherence (and size) to be analyzed. Where roots and SOM cause difficulty in finding and isolating clods, there is the concern that obtained clods are from areas possibly different in SOM kind or amount, and root penetration resistance (i.e. $\mathrm{Db}$ ). It is particularly a concern in A horizons where SOC and nutrients are relatively high in concentration, and errors are likely to be greatest. (Clods were not observed in any $\mathrm{O}$ horizons of this study.) Vincent and Chadwick (1997) and Huntington et al. (1989) utilized various excavation techniques and developed regression equations based on SOC for $\mathrm{O}$ and $\mathrm{A}$ horizon $\mathrm{Db}$ estimation. A review of $\mathrm{Db}$ values from the NSSL database (USDA-NRCS, Lincoln, NE: http://www.statlab.iastate.edu:80/soils/ssl/natch_data.html) revealed that West Virginia forest soil series A horizons generally had clod Db estimates in excess of $1.0 \mathrm{Mg} \mathrm{m}^{-3}$. Using the SOC values for those horizons in a regression developed by Huntington et al. (1989) from studies on soils similar to these, Db values obtained were generally less than $0.5 \mathrm{Mg} \mathrm{m}^{-3}$. This issue is presented in further detail in Chapter 5, where supplementary Materials and Methods and Results and Discussion sections regarding Db are presented. 
In those sections, data derived by clod and frame excavation (described below) are compared and discussed.

Bulk density of the forest floor and epipedon horizons were obtained using a relative elevation "frame" excavation method (Grossman et al., 2001). The frame method basically allows a volume to be excavated, dried, and weighed. It is less cumbersome than displacement techniques (Blake and Hartge, 1986), and is measured over a greater surface area. This method entails anchoring a $0.1 \mathrm{~m}^{2}$ wooden frame above the soil surface. After removing recent leaf litter, average thickness of each horizon was determined from 35 equidistant measuring points ( 7 rows of 5 measuring locations) in a slotted piece of plexiglas. Large roots, and rocks too large to transport were measured to calculate their volume; other rock fragments $(>2 \mathrm{~mm})$ were sieved and weighed at the National Soil Survey Laboratory in Lincoln, NE. Unfortunately, all the frame bulk density samples were lost at the USDA-NRCS National Laboratory, and resampling in the fall of 1997 allowed time to revisit only 8 pedons of the original 16 for this work. Two pedons from each of the 4 series were resampled. Thus, it was possible to gather some frame-Db data from O horizons developed from both deciduous (Mandy, Snowdog) and evergreen sites (Gauley, MWD Gauley). The Db values used for SOC and nutrient stock estimation in this study for all O horizons, and most other epipedon horizons are pooled estimates for either hardwood- or spruce-dominated sites. 
Thus, frame excavation bulk density was determined by horizon as in [1],

$$
\mathrm{Db}=\frac{(\mathrm{Ws}-\mathrm{Wr})}{\left[\left(\mathrm{Dax} .1 \mathrm{~m}^{2}\right)-\mathrm{Wr} / 2.5 \mathrm{Mg} \mathrm{m}^{-3}-\mathrm{Vrd}\right]}
$$

where $\mathrm{Db}=$ bulk density $\left(\mathrm{Mg} \mathrm{m}^{-3}\right) ; \mathrm{Ws}=$ oven-dry sample weight $(\mathrm{Mg}) ; \mathrm{Wr}=$ sieved rock weight $(\mathrm{Mg}) ; \mathrm{Da}=$ average horizon thickness $(\mathrm{m})$; and $\mathrm{Vrd}=$ rock and root volume removed and discarded at the sample site $\left(\mathrm{m}^{3}\right)$. We used a rock density of $2.5 \mathrm{Mg} \mathrm{m}^{-3}$, because most fragments were moderately weathered sandstone. The frame-excavation $\mathrm{Db}$ method was used at two pedons of each series, with the resulting Db horizon estimates averaged and applied to all pedons (e.g. Oi, Oe, etc.). The undecomposed leaf litter layer (usually $2 \mathrm{~cm}$ or less) was given an arbitrary $\mathrm{Db}$ of $0.05 \mathrm{Mg} \mathrm{m}^{-3}$. The estimates of $\mathrm{Db}$ developed by these methods are presented and discussed in detail in following chapters.

\section{Biomass and Dead Woody Debris}

Above-ground biomass was sampled at each pedon site concurrent with soil sampling. Methods were employed to estimate sawtimber, sapling, seedling, shrub, and herb layers of vegetative biomass (Table 3.2). Additionally, standing dead vegetation and downed/dead woody debris (DWD) were measured. These methods are developed from an unpublished protocol for carbon sequestration studies to be performed by soil scientists (e.g. non-experts in biomass sampling). This method was developed by David Kingsbury (USDA-NRCS), Robert Grossman (USDA-NRCS), and Linda Heath (USFS). 
Table 3.2. Biomass parameters measured at the pedon sampling locations.

\begin{tabular}{|c|c|c|}
\hline$\underline{\text { Parameter }}$ & Criteria & $\underline{\text { Dependent variable(s) measured. }}$ \\
\hline Sawtimber & $\mathrm{DBH}>12.7 \mathrm{~cm}$ & DBH, species. \\
\hline Saplings & $2.5 \mathrm{~cm}<\mathrm{DBH}<12.7 \mathrm{~cm}$ & DBH, species. \\
\hline Seedlings & $0.25 \mathrm{~cm}<\mathrm{DBH}<2.5 \mathrm{~cm}$ & DBH, species. \\
\hline Seedlings & $30 \mathrm{~cm}<$ height $<120 \mathrm{~cm}$ & Height, species. \\
\hline Shrubs & non-tree species & Height, species. \\
\hline Herbs, moss & $5-1 \mathrm{~m}^{2}$ areas harvested & Oven dry weight. \\
\hline DWD & $\mathrm{D}>1.9 \mathrm{~cm}, \mathrm{~L}>90 \mathrm{~cm}$ & Diameter, length, decay class. \\
\hline
\end{tabular}

\section{Biomass Measurement and Sampling}

\section{Sawtimber}

At each soil sampling site, circular plots were established and the diameter at breast height $(\mathrm{DBH})$ and species of all trees $12.7 \mathrm{~cm}$ or larger were recorded. Plot size was 0.08 ha except where 90 percent or more of trees had DBH smaller than $23 \mathrm{~cm}$, in which case 0.04 ha plots were established (one site only in this study). Dead trees also were measured, and trees with split-trunks (at or below breast height) were recorded. Where split-trunk trees occurred, a reduction in biomass was assumed to be present as opposed to individual trees. This was accounted for by reducing the biomass estimates of all but one stem (the first counted) of split trunks by 50 percent. 


\section{Saplings and Smaller Vegetation}

Sub-plot markers (stakes) were established at 5 points, each $11.3 \mathrm{~m}$ from the plot center (sampled soil pedon). These points occurred at $72^{\circ}$ intervals around the plot center (e.g. $\left.0^{\circ}, 72^{\circ}, 144^{\circ} \ldots\right)$. At each subplot marker, a radius was established within which saplings, seedlings, and shrubs were measured. All saplings with DBH from 2.5 to $12.7 \mathrm{~cm}$ were measured (DBH) within a $2.07 \mathrm{~m}$ radius. The same was done for saplings from 0.25 to $2.5 \mathrm{~cm}$ in a $1.13 \mathrm{~m}$ radius, unless fewer than five individuals occurred, in which case the plot size increased to a $2.07 \mathrm{~m}$ radius. Species and height of seedlings from 0.30 to $1.2 \mathrm{~m}$ tall were recorded as to species and height within a $1.13 \mathrm{~m}$ radius, unless fewer than five individuals occurred, in which case the plot size increased to a $2.07 \mathrm{~m}$ radius. Shrubs were recorded as to the species and number of stems within a $1.13 \mathrm{~m}$ radius, unless fewer than five individuals occurred, in which case the plot size increased to a 2.07 m radius.

The data gathered were analyzed using allometric equations for estimating dry matter as summarized by Wharton and Griffith (1993, 1998), including some equations for saplings, seedlings, and shrubs compiled from Young et al. (1980). Herbs were measured directly by establishing $1 \mathrm{~m}^{2}$ squares, using each subplot marker as a corner. All herbs were cut at ground level in these areas, oven-dried (over night at $115^{\circ} \mathrm{C}$ ), and weighed. 


\section{$\underline{\text { Allometric Equations for Biomass Estimation }}$}

The only variables recorded for use in allometric equations for trees and saplings are species and diameter at breast height (DBH at $1.37 \mathrm{~m}$ ), with the exception of herb layer biomass - which was measured directly. The value of measuring tree height is considerable for strengthening estimates of merchantable volumes of timber (Wiant et al., 1977, Wiant and Wingerd, 1981). However, overall site biomass deviates from simple site-index or merchantable material indications (Wiant and Fountain, 1980), and is sufficiently estimated by basal area (Wiant et al., 1984). Allometric equations for the estimation of whole-tree (i.e. above and below-ground) biomass were used for this study (Wharton and Griffith, 1993; 1998; Young et al., 1980) and are summarized below. For sawtimber and saplings ( $2.5 \mathrm{~cm}$ and greater), biomass was calculated as in equation [2] for red maple, sugar maple, American beech, red spruce, yellow birch, and hemlock, with specific above- and below-ground coefficients $\left(b_{0}, b_{1}\right)$ for each (Wharton and Griffith,

$$
\operatorname{Ln} \mathrm{Y}=\mathrm{b}_{\mathrm{o}}+\mathrm{b}_{1} \operatorname{Ln}(\mathrm{DBH})
$$

1993, 1998). Biomass for yellow poplar, black cherry, and red oak specific coefficients were applied as in equation [3]. For these species, coefficients only applied to above-

[3] $\quad \log Y=\log b_{o}+b_{1} \log (D B H)$

ground biomass. In order to gain an estimate of whole-tree biomass, the above-ground biomass estimate was multiplied by a factor of 1.23 , which is the weighted average 
effective increase between above-ground and whole-tree estimates for the other hardwood species in this study (range 1.22 to 1.25 ). For these size classes, DBH was in units of inches and $\mathrm{Y}$ was dry biomass in pounds. All data were converted to metric units.

For saplings with DBH from .25 to $2.29 \mathrm{~cm}$ and seedlings from 0.30 to $1.22 \mathrm{~m}$ tall, species-specific coefficients from Young et al. (1980) were applied to equation [2]. For shrubs, median stem diameter (D) was applied as in equation [4] from Wharton and Griffith et al. (1993). For these biomass classes, $\mathrm{Y}$ is dry grams of biomass.

[4] $\quad \mathrm{Y}=\mathrm{b}_{\mathrm{o}}(\mathrm{D})^{\mathrm{bl}}$

Some species were encountered for which allometric equations for biomass have not been developed. Among saplings and small trees (less than $12.5 \mathrm{~cm} \mathrm{DBH}$ ), mountain holly (Ilex montana L.\& C.) and serviceberry (Amalanchier spp.) were common. For these species, equations for Nemopanthus mucronata L. and yellow birch were used as being the most similar in density and growth habit. Among shrubs, Rhodendron maximum $\mathrm{L}$. and Kalmia latifolia L. were very common. Biomass estimates for these species had to be made using equations developed for $R$. canadense and $K$. angustifolia, respectively.

Dead trees were assumed to have lower densities than live trees, and the biomass estimate from the applicable allometric equation was reduced by 50 percent. Where trees had split-trunks, the largest stem was calculated as described above. The biomass estimate 
from the allometric equation was reduced by 50 percent for secondary and other stems, as it was anticipated that crowding would reduce normal crown development.

For herbaceous collection, one site (93008, Blackwater series) was sampled after a hard frost, which may have affected herb sampling. Herb species were not recorded, but as a rule these study sites did not have diverse forb communities. Hay scented fern (Dennstaedtia punctilobula M.), wood sorrel (Oxalis sp.), club mosses (Lycopodium sp.) and mosses almost exclusively comprised the herb layers at these sites, regardless of the time during the growing season.

The conversion of oven-dry biomass weight to organic carbon was made by multiplying by 0.5 , which is within commonly published values of about 49.1 to 52.1 percent for hardwoods and softwoods, respectively (Birdsey, 1992 a, b; Brown and Lugo, 1982; Grigal and Ohman, 1992; Wharton and Griffith, 1993, 1998).

\section{Dead Woody Debris}

Dead woody debris was measured along 2 perpendicular sample lines, each $32 \mathrm{~m}$ long. The same transect lines that had been established for surface rock fragment estimation were utilized for DWD measurement. The purpose of the perpendicular nature was to avoid errors possibly associated with the fact that sources of DWD can be directionally oriented on a site. An example would be a dominant blow-down direction either from prevailing winds or a particularly destructive storm (Grushecky et al., 1998). Diameter, 
length, and decay class were recorded for all pieces of DWD in excess of $2.2 \mathrm{~cm}$ and 120 $\mathrm{cm}$ long touching the imaginary vertical plane of the sample line. Four decay classes were established, with Class 1 being essentially undecomposed. Class 2 DWD was generally sound to slightly rotten. Class 3 DWD was generally rotten, with bark "sloughing or detached". Class 4 was the most decomposed class recognized, and is generally "doughy" when wet, branches have pulled out, and has no structural integrity.

Calculation involved somewhat arbitrarily assigning wood density to the decay classes at each site. Species of DWD were not recorded, therefore a density was developed for each site using oven-dry (12\% moisture) species densities from Hoadley (1990), based on the weighted average of living tree species occurrence. These data are included in Appendix D. This initial species density was then somewhat arbitrarily assigned a percentage of the presumed initial (living) dry density for the site as described above. Decay class 1 was assumed to have original wood density. Decay class 2 was assigned a $70 \%$ of original density, and classes 3 and 4 were assigned 40 and 25 percent, respectively. These assignments were developed in discussions with Linda Heath, USFS, who is currently working on publications regarding DWD measurement and description. Transect (sample line) data were applied to obtain volume estimates using equation [5],

$$
\mathrm{V}=\pi^{2} \Sigma \mathrm{d}^{2} / 8 \mathrm{~L} \times 43,560 \mathrm{ft}^{2} \mathrm{ac}^{-1} / 144 \mathrm{in}^{2} \mathrm{ft}^{-2}
$$

where $\mathrm{V}$ is wood volume in $\mathrm{ft}^{3} \mathrm{ac}^{-1}, \mathrm{~L}$ is the sample line length in feet and $\mathrm{d}$ is the diameter of each piece of DWD recorded along the sample line. English units were converted to metric, and volumes were converted to mass per area by use of the density 
assignments as described above. The equation above was developed from personal communications with Linda Heath, USFS, and applied as described by Grushecky et al. (1998).

\section{Comparisons of Soil and Vegetative Organic Carbon Estimates}

In addition to developing biomass and biomass $\mathrm{C}$ estimates for the soil series, singlefactor ANOVA procedures were employed for identifying differences in SOC among series (Dowdy and Weardon, 1991). In looking for possible relationships of site biomass, simple linear regression relationships were examined for site biomass $\mathrm{C}$ plotted against SOC, exchangeable base cations, extractable $\mathrm{P}$, and total $\mathrm{Ca}, \mathrm{Mg}$ and $\mathrm{P}$. Sawtimber species diversity (the number of sawtimber species observed at each site) was plotted against SOC, as well as the nutrient parameters noted above.

\section{CHEMICAL ANALYSES AND NUTRIENT POOLS}

Each pedon was chemically and physically characterized by horizon, with all samples analyzed at the National Soil Survey Laboratory (NSSL) in Lincoln, Nebraska, according to standard soil survey procedures (National Soil Survey Laboratory Staff, 1996). All samples were air-dried and sieved through a $2 \mathrm{~mm}$ screen prior to analyses. Soil texture was determined by the pipette method.

Walkley-Black organic carbon, and combustion furnace "total" $\mathrm{C}$ were determined for the series (Nelson and Summers, 1996). Total C analyses were performed for 12 of the 18 
pedons in this study. The soils of this study area are very acid and do not contain carbonates, however there have been forest fires which could have contributed significant charcoal deposits to these soils. Additionally, there could be carbolithic rock fragments in some horizons due to coal or carbolithic materials that occur in the geologic strata of the region. Presumably, where greater $\mathrm{C}$ concentrations are indicated by the combustion method, carbolithic or charcoal carbon is likely to be responsible. Therefore, SOC from these methods will be compared in an effort to examine the significance of charcoal or carbolithic materials in the series.

Chemical analyses included 1:1 $\mathrm{pH}$ in water, $1 \mathrm{M} \mathrm{NH}_{4} \mathrm{OAc}$ exchangeable bases and $\mathrm{CEC}$, $\mathrm{KCl}$ extractable $\mathrm{Al}$, and Bray extractable $\mathrm{P}$. Total elemental analyses of $\mathrm{Ca}, \mathrm{Mg}$, and $\mathrm{P}$ were conducted by nitric acid digestion (EPA method 3051), and analyzed by ICP atomic emission spectrophotometry (ICP-AES, Perkin Elmer, Model 40, Norwaki, CT). Total elemental analyses were performed by staff of the West Virginia Agricultural and Forestry Experiment Station (WVAFES) at West Virginia University. Only total Ca, Mg, and $\mathrm{P}$, and organic carbon were determined for the recent litter layer horizons (Oi1). Some supplementary analyses were performed by the WVAFES soils laboratory, where NSSL data were incomplete or apparently anomalous. These analyses include extractable $\mathrm{Ca}, \mathrm{K}, \mathrm{Mg}, \mathrm{P}$, and $\mathrm{Al}$.

All nutrient stocks and C were calculated by horizon, to a depth of $150 \mathrm{~cm}$ or to bedrock, whichever was shallower. The recent litter layer (Oi1) was described and sampled for all pedons. However, Oil horizons are not included in the estimation of areal SOC stocks. The reason for this is that the recent litter layer is seldom included in published estimates 
of SOC; it is extremely variable in thickness, content, and occurrence over very small areas; and is totally dependent on the time of year and contemporary weather patterns as to its presence and thickness. Conversely, the data for the Oil layer were considered in nutrient calculations and relationships examined between SOC and nutrient distributions. This is because the nutrient pools of the series are evaluated in the context of potential deficiency, therefore it is felt that even tenuously characterized horizons should be included. In other words, I wished to err conservatively with regard to SOC estimates, and towards potentially overestimating nutrient reserves rather than to bias towards deficiency scenarios.

A one-way analysis of variance (ANOVA) was used to test for significant differences in $\mathrm{Ca}, \mathrm{Mg}$, and P content among the series. Least Significant Difference (LSD) was used to compare adjacent means with a prior significant $F$ value (Dowdy and Weardon, 1991). The Student's T test was used to determine if restricting sampling depths causes significant differences in SOC and areal nutrient estimates within series.

Mineralogy for each pedon was determined by the grain count method by the USDA NSSL. For better identification of spodic properties, the optical density of ammonium oxalate extract (ODOE) was measured for most horizons, at the NSSL. Ammonium oxalate extractable $\mathrm{Fe}$ and $\mathrm{Al}$ also were measured for most horizons. The criteria for identification of some spodic horizons, and thus some spodosols, are an ODOE of 0.25 or more, and one half the oxalate $\mathrm{Fe}+$ the oxalate $\mathrm{Al}$ of 0.50 or more (Soil Survey Staff, 1998). 


\section{SOIL MICROBIAL BIOMASS CARBON}

The Mandy and Gauley series were selected to look comparatively at soil microbial biomass carbon $(\mathrm{SMBC})$, due to the contrasting vegetative and morphological characteristics of the series. Field moist samples of the Oe and A (or AE ) horizons were collected from sites 083003 and 093007 (Gauley), and 093004 and 093005 (Mandy) during the spring of 1996. Thus, both a partially decomposed organic horizon and the uppermost mineral horizon were sampled at each site, possibly showing differences in SMBC resulting from substrate quantity and quality differences within the pedon. Three samples of each of the horizons were collected at and around each pedon site (pedon face, and $10 \mathrm{~m}$ south and north of the pedon). This limited selection is hoped to indicate differences in SMBC resulting from vegetation, soil types, and horizons. The soil samples were then refrigerated in field-moist condition until preparation and analysis approximately one month later.

The chloroform fumigation method is perhaps the most common means of assessing the proportion of SOC attributable to living organisms (Joergensen, 1995; Paul and Clark, 1996). The method has been applied to forest soils, although the presence of fine roots and the typically high acidity complicates measurement considerably (e.g. Vance et al., $1987 \mathrm{a}, \mathrm{b}, \mathrm{c})$. The variety of organisms and states of decay in SOM make it difficult to accurately quantify SMBC, and the high acidity of some forest soils is hypothesized to interfere with the incubation phase of fumigation techniques. However, when the incubation phase is eliminated, and the purpose of the extraction is restricted to 
comparative uses, it seemed worthwhile to look at a subset of the study sites and horizons (Vance et al., 1987b, c).

The samples were extracted using a variation of the chloroform fumigation extraction incubation method employed by Vance et al. (1987a, b) and further outlined by Horwath and Paul, (1994). The referenced methods entail the fumigation of a soil sample (typically with chloroform) in order to kill and lyse living cells, followed by inoculating with active soil, and subsequent extraction with a sulfate salt. However, for this study, only an extraction was performed - without subsequent incubation, so as to eliminate problems encountered in extremely acid soils such as these (Vance et al., 1987a).

The soil samples were not sieved, rather they were (subjectively) selected from the original field bulk sample as being representative portions. From these portions the obvious roots were removed prior to sample weighing. Twenty-five grams of field moist sample from each sampled horizon were placed into two 250-ml Erlenmeyer flasks. One flask was for fumigation, the other for control (unfumigated) extraction. A separate subsample from each horizon was oven-dried to obtain the percentage (by weight) of soil moisture, then discarded.

Following a 24-hour equilibration period, each flask was sealed with a 2-ml aliquot of reagent-grade chloroform (from which the ethanol had been distilled and discarded) in a test tube. A weak vacuum was placed on the flasks by means of drawing a 60 -ml syringe of air from the side of the rubber stoppers. Fumigation was conducted under an exhaust 
hood and was concluded in about 24 hrs. Flasks were evacuated of residual chloroform and test tubes were removed. The samples were then extracted into $150 \mathrm{ml}$ of $0.5 \mathrm{M}$ $\mathrm{K}_{2} \mathrm{SO}_{4}$, briefly shaken every 0.5 hours for 1.5 hours, filtered through Whatman \#1 paper, and frozen at $-15^{\circ} \mathrm{C}$ until thawed for analysis by the Walkley-Black method. The concentration of SMBC was calculated for each sample after subtracting the amount of carbon extracted from the control.

The extracted solution was then analyzed for C content. The sample SMBC concentration was calculated as in [6]:

$$
(\mathrm{Cb})=\frac{(\mathrm{Cs})-(\mathrm{Cc})}{\mathrm{Kec}}
$$

Where $\mathrm{Cb}$ is the $\mathrm{SMBC}$ concentration, $\mathrm{Cs}$ is the fumigated sample concentration, $\mathrm{Cc}$ is the control (unfumigated), and Kec is the extraction coefficient. The Kec is an estimate of the efficiency of conversion of actual biomass $\mathrm{C}$ to that analyzed, and generally ranges from 0.18 to 0.41 (Joergensen, 1996). For this study, a Kec of 0.35 was used. This Kec value was chosen after comparison of that used in other forest soils, and on the advice of Dr. Alan Sexstone based on the method of C analysis (Joergensen, 1996).

Thus, estimates for each horizon of each site were obtained by pooling 3 values. The estimates of SMBC were compared between series, and for horizons within series, using single factor ANOVA (Dowdy and Weardon, 1991). Estimates of SMBC are to be 
plotted against soil $\mathrm{pH}, \mathrm{SOC}$, and $\mathrm{Al}$ saturation to test for relationships to these soil characteristics within soil horizons.

\section{REFERENCES}

Birdsey, R.A.(a) 1992. Changes in forest carbon storage from increasing forest area and timber growth.. p. 23 - 39. In Sampson, R.N. and D. Hair (ed.) Forests and global change. Vol. 1: Opportunities for increasing forest cover. American Forests, Washington DC.

Birdsey, R.A. (b) 1992. Carbon storage and accumulation in United States forest ecosystems. USDA Forest Service GTR WO-59.

Blake, G.R., and K.H. Hartge. 1986. Bulk density. p. 363-375. In A. Klute (ed.) Methods of soil analysis. Part 1. $2^{\text {nd }}$ ed Agron. MonMonogr. 9. ASA and SSSA, Madison, WI.

Brown, S.L., and A.E. Lugo. 1982. The storage and production of organic matter in tropical forests and their role in the global carbon cycle. Biotropica 14: 161-187.

DiGiovanni, D.M. 1990. Forest Statistics of West Virginia -- 1975 and 1989. NE Forest Experiment Station, Broomall, Pennsylvania. 
Dowdy, S. and S. Weardon. 1991. Statistics for Research. John Wiley and Sons, Inc., New York, NY.

Erich, S.E., and G.M. Trusty. 1997. Chemical characterization of dissolved organic matter released by limed and unlimed forest soil horizons. Can J. Soil Sci. 77:4045-413.

Fernandez, I.J., L.E. Rustad, and G.B. Lawrence. 1993. Estimating total soil mass, nutrient content, and trace metals in soils under a low elevation spruce-fir forest. Can. J. Soil Sci. 73: 317-328.

Flegel, D.G. 1999. Soil Survey of Pocahontas County, West Virginia. USDA-Natural Resources Conservation Service, Washington, DC.

Grigal, and L.F. Ohmann. 1992. Carbon storage in upland forests of the lake states. Soil Sci. Soc. Am. J. 56: 935-943.

Grossman, R.B, D.S. Harms, D.F. Kingsbury, R.K. Shaw, and A.B. Jenkins. 2001. Assessment of soil organic carbon using the U.S. soil survey. p. 87 - 104. In Lal et al. (ed.) Assessment Methods for Soil Carbon. Lewis Publishers, Boca Raton, Florida.

Grushecky, S.T., C.C. Hassler, and M.A. Fajvan. 1998. Logging residue yield equations from West Virginia timber harvests. North.J. Appl. For. 15(1):14-16. 
Hicks, R.R.Jr., and P.S. Frank. 1984. Relationship of aspect to soil nutrients, species importance, and biomass in a forested watershed in West Virginia. For. Ecol. and Mngt. $8: 281-291$.

Hoadley, R.B. 1990. Identifying wood: accurate results with simple tools. Taunton Press, Newtown, CT 223p.

Horwath, W.R., and E.A. Paul. 1994. Microbial biomass. p. 753 - 773. In Methods of soil analysis, part 2. Microbiological and biochemical properties - SSA book series, no. 5. Madison, Wisconsin.

Huntington, T.G., C.E. Johnson, A.H. Johnson, T.G. Siccama, and D.F. Ryan. 1989. Carbon, organic mater, and bulk density relationships in a forested spodosol. Soil Sci. 148(5):380-386.

Joergensen, R. 1995. The fumigation extraction method. p. 375-396. In Alef, K., and Nannipieri, P. Methods in applied soil microbiology and biochemistry. Academic Press, London.

Joergensen, R. 1996. The fumigation-extration to estimate soil microbial biomass: calibration of the Kec value. Soil Biol. and Biochem. 28 (1):25-31. 
Losche, C.K., and W.W. Beverage. 1967. Soil survey of Tucker County and part of northern Randolph County, West Virginia. USDA - Soil Conservation Service. U.S. Government Printing Office. Washington, D.C.

Manrique, L.A., and C.A. Jones. 1991. Bulk density of soils in relation to soil physical and chemical properties. Soil Sci. Soc. Am. J. 55: 476-481.

National Soil Survey Laboratory Staff, 1996. Soil survey laboratory methods manual. USDA-Natural Resources Conservation Service Soil Survey Invest. Report No. 42, version 3.0. Lincoln, Nebraska.

Nelson, D.W., and L.E. Sommers. 1996. Total carbon, organic carbon, and organic matter. p. 961-1010. In D.L. Sparks (ed.) Methods of soil analysis. Part 3. SSSA Book Ser. 5. SSSA, Madison, WI.

Paul, E.A., and F.E. Clark. 1996. Soil Biology and Biochemistry. Academic Press, San Diego, CA $340 \mathrm{p}$.

Price, P.H. 1968. Geologic map of West Virginia. WV Geologic and Economic Survey.

Reger, D.B. 1931. West Virginia Geological Survey - Randolph County. Wheeling News LithoCompany, Wheeling, West Virginia. 989 p. 
Reger, D.B. 1923. West Virginia Geological Survey - Tucker County. Wheeling News Litho Company, Wheeling, West Virginia. 542 p.

Shipp,R.F., and R.P. Matelski. 1965. Bulk-density and coarse-fragment determinations on some Pennsylvania soils. Soil Sci. 99:392-397.

Soil Survey Staff, 1998. Keys to Soil Taxonomy, $8^{\text {th }}$ edition, USDA-Natural Resources Conservation Service.

Tajchman, S.J., R. Benyon, L. Bren, J. Kochenderfer, and C. Pan. 1996. On spatial variability of above-ground biomass. Biomass and Bioenergy 11(5):383-386.

Tajchman, S.J., and H.V. Wiant. 1983. Topography and biomass characteristics of a forested catchment in the northern Appalachians. For. Ecol. Mngt. 5:55-69.

USDA. 1981. Major Land Resource Areas of the United States. U.S. Department of Agriculture, Soil Conservation Service. Agricultural handbook 296. Washington, D.C.

Vance, E.D., Brooks, P. C., and D. S. Jenkinson. 1987 (a). Microbial biomass measurements in forest soils: determination of the Kc values and tests of hypotheses to explain the failure of the chloroform fumigation-incubation method in acid soils. Soil Biol. and Biochem. 19 (6):689-696. 
Vance, E.D., Brooks, P. C., and D. S. Jenkinson. 1987 (b). Microbial biomass

measurements in forest soils: the use of the chloroform fumigation-incubation method in strongly acid soils. Soil Biol. and Biochem. 19 (6):697-702.

Vance, E.D., Brooks, P. C., and D. S. Jenkinson. 1987 (c). An extraction method for measuring soil microbial biomass carbon. Soil Biol. and Biochem. 19 (6):703-707.

Vincent, K.R., and O.A. Chadwick. 1994. Synthesizing bulk density for soils with abundant rock fragments. Soil Sci. Soc. Am. J. 58:455-464.

Wharton, E.H., and D.M. Griffith. 1998. Estimating total forest biomass in Maine, 1995. USFS Res. Bull. NE-142. Northeastern Res. Sta., Radnor, PA. 50 p.

Wharton, E.H., and D.M. Griffith. 1993. Methods to estimate total forest biomass for extensive forest inventories: applications in the Northeastern U. S. USFS Res. Bull. NE681. Northeastern Res. Sta., Radnor, PA 52 p.

Wiant, H.V., Jr., and M.S. Fountain. 1980. Oak site index biomass yield in upland oak and cove hardwood timber types in West Virginia. USFS Res. Note NE-291. USFS Northeastern For. Exp. Res. Sta., Broomall, PA. 2 p. 
Wiant, H.V., Jr., R. Knight, and J.E. Baumgras. 1984. Relation of biomass to basal area and site index on an Appalachian watershed. Res. Note NE-315. USFS Northeastern Forest Exp. Sta., Broomall, PA. 4 p.

Wiant, H.V., Jr., C.E. Sheetz, A. Colaninno, J.C. DeMoss, and F. Castaneda. 1977. Tables and procedures for estimating weights of some Appalachian hardwoods. WV Agr. For. Exp. Sta. Bull. 659T., Morgantown, WV. 36 p.

Wiant, H.V., Jr., and D.E. Wingerd. 1981. Biomass factors for point sampling in Appalachian hardwoods. J. For. 79(1):21-29.

Young, H.E., J.H. Ribe, and K. Wainwright. 1980. Weight tables for tree and shrub species in Maine. Misc. Rep. 230. Univ. of Maine, Life Sci. Agr. Exp. Sta., Orono, ME. $84 \mathrm{p}$. 


\section{CHAPTER FOUR}

\section{MORPHOLOGY AND TAXONOMY OF THE SOILS}

All of the soil types examined in this work will be correlated into published soil surveys at some level of taxonomic distinction; most likely as series. The soil morphological descriptions and resulting classification, as well as the genetic and site geomorphic characteristics are detailed in Appendix A.

As mentioned previously, Blackwater and MWD Gauley are tentative series pending further investigation and correlation. The Gauley, Mandy, and Snowdog series are established and correlated in several counties of West Virginia (e.g. Delp 1998, Flegel 1999). All the series are either inceptisols (Blackwater, Mandy, Snowdog) or spodosols (Gauley, MWD Gauley), both as correlated and as indicated by the laboratory analyses from this study (Appendix B). The ensuing discussion about the taxonomic considerations of the pedons will be divided among the inceptisols and spodosols, and broken down by successive level of classification from order to series parameters.

\section{SOIL ORDER}

Analogous soils to Mandy and Snowdog on corresponding lower elevation landforms in West Virginia are correlated as ultisols, specifically the Gilpin and Laidig series, respectively. The mesic soils are further described in Chapter 7. Interestingly, none of the pedons sampled in this study have sufficient illuvial activity to indicate the presence of 
argillic horizons. Only one pedon of the Mandy series (083007) has a clay content (Appendix B) demonstrating sufficient clay increase to meet the requirements of an argillic horizon. This may be somewhat counter-intuitive, given the apparently high degree of weathering that has taken place in these soils. For example, the Mandy pedon at site 093004 exhibits andic soil properties - due to the presence of poorly-crystalline clays and low bulk density of the fine-earth fraction. However, little or no morphological evidence of illuviation was observed in these pedons. It is conceivable that soil temperature could account for the lack of illuvial activity, but this is purely hypothetical. Due to the absence of fine clay data and micromorphological observations, further genetic and taxonomic speculation is avoided here. The pedons of the Blackwater series appear to fit well as inceptisols, and have no known mesic analogues.

Among the spodosol series, most pedons (Appendix B) met the spodic materials color requirement of 5YR, as well as one or both of the requirements for optical density of oxalate extract and ammonium oxalate extractable Fe and Al percentages (Soil Survey Staff, 1998). All pedons among these series classed as spodosols. All pedons among the spodosols have albic horizons.

\section{SUBORDER, SUBGROUP, AND GREAT GROUP CLASSIFICATION}

Among the inceptisols, all are of the udic suborder. Some anecdotal evidence exists for perudic designation in these areas (personal communication with Dr. M.B. Adams, Fernow Experimental Forest), however published delineations were not found by this author. The diagnostic fragipan of the Snowdog series warrants placement as a 
Fragiudept, while the fragic soil properties and seasonal high water table of the Blackwater series places it in the Fragiaquic great group of Dystrudepts. A lack of further distinguishing diagnostic horizons leaves the Mandy series as Typic Dystrudepts.

Among the spodosols, the well drained Gauley series has a relative absence of diagnostic horizons and thus, is given the classification of Typic Haplorthods. Interestingly, the occurrence of redoximorphic features within $50 \mathrm{~cm}$ of the mineral soil surface and in the spodic horizons of the MWD Gauley series results in a suborder-level aquic moisture regime designation. Despite this, the series is moderately well drained (e.g. seasonal high water table evidence generally more than $40 \mathrm{~cm}$ below the soil surface). Intuitively, one might expect these soils to class as aquic at the great group level. Taxonomically, aquic appears as a taxonomic class at the suborder and great group, and oxyaquic occurs at the great group as a possibility for orthods (Soil Survey Staff, 1998). These MWD Gauley pedons do not have evidence of (endo-) saturation in all layers below the spodic horizon, and therefore are Typic Epiaquods. Pedons 093002 and 093003 (MWD Gauley) had placic horizons. However, because the placic horizons extended through generally less than $50 \%$ of the pedons, they were not sufficient to change the classification to Placorthods.

\section{FAMILY CLASSIFICATION}

The Mandy and Blackwater pedons are all loamy-skeletal. The Snowdog pedons are fineloamy. However, they are typically close to meeting the volumetric requirement to be classed as loamy-skeletal (Soil Survey Staff, 1998). This situation is typical of not only 
Snowdog, but of its analogues and many other similar colluvial or colluvially influenced soils on uplands of this region. In soils on old surfaces of contrasting lithology and differentially weathering strata, the continuum of soil particle size characteristics spans taxonomic distinctions beyond the capability of reasonable delineation in soil surveys. Thus, Snowdog pedons may be on the more skeletal side of the fine-loamy distribution, and some Mandy pedons may be on the more fine-loamy side of the skeletal particle size class distribution.

The particle size class of all Gauley pedons and 2 MWD Gauley pedons (083002, 083006) are loamy-skeletal. The other 2 MWD Gauley pedons are coarse-loamy, and at this point it is unclear if they represent a large population of non-skeletal spodosols which are "hidden" by the typical veneer of resistant sandstone surface fragment cover.

The mineralogy of the pedons is shown in Table 4.1. The existing as-published mineralogy classification of the Mandy and Snowdog series is mixed (http://www.statlab.iastate.edu/soils/ssl/natch_data.html). While only three of the eight pedons classed sampled here classed as siliceous, it appears that the inceptisols of this study are at the extremely low fertility end of mixed mineralogy. The average percentage of siliceous materials in the control sections of the Mandy and Snowdog are 85 and 87.5, respectively. Prior to this study, no mineralogical analyses for these series are known to exist. More detailed mineralogical data are presented for the pedons in Appendix C. 
The CEC activity classes did not deviate widely within series (Table 4.2). Among those series already officially correlated, CEC activity class is not listed. To date, they have not been updated to the $8^{\text {th }}$ edition of Soil Taxonomy (Soil Survey Staff, 1998). The data resulting from this work will no doubt be used to update these series.

The temperature regime of these series is assumed to be frigid, based solely upon the elevation and latitude of the sample sites, which range from 1100 to $1300 \mathrm{~m}$. The approximate elevation at which mean annual soil temperature (MAST) drops below $8^{\circ} \mathrm{C}$

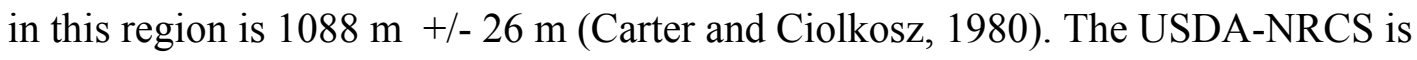
currently involved in gathering more information for the delineation of frigid and mesic temperature regimes on the Allegheny Plateau. 
$\underline{\text { Table 4.1. Mineralogy class of the pedons (by grain count). }}$

\begin{tabular}{|c|c|c|c|}
\hline$\underline{\text { Series }}$ & $\underline{\text { Pedon }}$ & $\underline{\text { Mineralogy }}$ & $\underline{\text { Percent Siliceous }^{\dagger}}$ \\
\hline \multirow[t]{2}{*}{ Blackwater } & 093001 & siliceous & 99 \\
\hline & 083008 & siliceous & 97 \\
\hline \multirow[t]{4}{*}{ Gauley } & 075001 & siliceous & 99 \\
\hline & 075002 & siliceous & 99 \\
\hline & 083003 & siliceous & 99 \\
\hline & 093007 & siliceous & 99 \\
\hline \multirow[t]{4}{*}{ MWD Gauley } & 083002 & siliceous & 99 \\
\hline & 083006 & siliceous & 99 \\
\hline & 093002 & siliceous & 99 \\
\hline & 093003 & siliceous & 99 \\
\hline \multirow[t]{4}{*}{ Mandy } & 083005 & mixed & 73 \\
\hline & 083007 & siliceous & 100 \\
\hline & 093004 & mixed & 84 \\
\hline & 093005 & mixed & 83 \\
\hline \multirow[t]{4}{*}{ Snowdog } & 083001 & siliceous & 99 \\
\hline & 083004 & siliceous & 90 \\
\hline & 093006 & mixed & 86 \\
\hline & 093008 & mixed & 75 \\
\hline
\end{tabular}

${ }^{\dagger}$ Percent of total grains counted as quartz and other resistant aggregates. 
Table 4.2. Taxonomic classification of the pedons (Soil Survey Staff, 1998).

\begin{tabular}{|c|c|c|}
\hline Series & Pedon ID & Classification \\
\hline \multirow[t]{5}{*}{ Mandy } & 95WV083005 & $\begin{array}{l}\text { loamy-skeletal, siliceous, active, frigid Typic } \\
\text { Dystrudrept }\end{array}$ \\
\hline & 95WV083007 & loamy-skeletal, siliceous, active, frigid Typic \\
\hline & & Dystrudept \\
\hline & 95WV093004 & $\begin{array}{l}\text { loamy-skeletal, siliceous, superactive, frigid Andic } \\
\text { Dystrudept }\end{array}$ \\
\hline & 95WV093005 & $\begin{array}{l}\text { loamy-skeletal, siliceous, active, frigid Typic } \\
\text { Dystrudept }\end{array}$ \\
\hline \multirow[t]{4}{*}{ Snowdog } & 95WV093006 & $\begin{array}{l}\text { fine-loamy, siliceous, active, frigid Typic } \\
\text { Fragiudept }\end{array}$ \\
\hline & 95WV093008 & $\begin{array}{l}\text { fine-loamy, siliceous, active, frigid Typic } \\
\text { Fragiudept }\end{array}$ \\
\hline & 95WV083001 & $\begin{array}{l}\text { fine-loamy, siliceous, active, frigid Typic } \\
\text { Fragiudept }\end{array}$ \\
\hline & 95WV083004 & $\begin{array}{l}\text { fine-loamy, siliceous, active, frigid Typic } \\
\text { Fragiudept }\end{array}$ \\
\hline \multirow[t]{2}{*}{ Blackwater } & 95WV083008 & $\begin{array}{l}\text { loamy-skeletal, siliceous, semiactive, frigid } \\
\text { Fragiaquic Dystrudept }\end{array}$ \\
\hline & 95WV093001 & $\begin{array}{l}\text { loamy-skeletal, siliceous, semiactive, frigid } \\
\text { Fragiaquic Dystrudept }\end{array}$ \\
\hline \multirow[t]{3}{*}{ Gauley } & 95WV093007 & $\begin{array}{l}\text { loamy-skeletal, siliceous, superactive, frigid Typic } \\
\text { Haplorthod }\end{array}$ \\
\hline & 95WV075001 & $\begin{array}{l}\text { loamy-skeletal, siliceous, superactive, frigid Typic } \\
\text { Haplorthod }\end{array}$ \\
\hline & 95WV075002 & $\begin{array}{l}\text { loamy-skeletal, siliceous, superactive, frigid Typic } \\
\text { Haplorthod }\end{array}$ \\
\hline
\end{tabular}


Table 4.2 (continued). Taxonomic classification of the pedons (Soil Survey Staff, 1998).

\begin{tabular}{|c|c|c|}
\hline$\underline{\text { Series }}$ & Pedon ID & Classification \\
\hline Gauley & 95WV083003 & $\begin{array}{l}\text { loamy-skeletal, siliceous, superactive, frigid Typic } \\
\text { Haplorthod }\end{array}$ \\
\hline \multirow[t]{4}{*}{ MWD G } & 95WV083006 & $\begin{array}{l}\text { loamy-skeletal, siliceous, active, frigid Typic } \\
\text { Epiaquod }\end{array}$ \\
\hline & 95WV093002 & $\begin{array}{l}\text { coarse-loamy, siliceous, superactive, frigid Typic } \\
\text { Epiaquod }\end{array}$ \\
\hline & 95WV093003 & $\begin{array}{l}\text { coarse-loamy, siliceous, superactive, frigid Typic } \\
\text { Epiaquod }\end{array}$ \\
\hline & 95WV083002 & $\begin{array}{l}\text { loamy-skeletal, siliceous, active, frigid Typic } \\
\text { Epiaquod }\end{array}$ \\
\hline
\end{tabular}

\section{SERIES-LEVEL CONSIDERATIONS}

Among the established series examined in this study, these pedons generally fit into the correlated paradigms of soil morphological characteristics as published in soil surveys of the region (e.g. Delp 1998, Flegel 1999). The most notable deviations from series' ranges in characteristics are limited to depth to bedrock (exceeded slightly in some Mandy and Gauley pedons), and the evidence of siliceous mineralogy class for Mandy and Snowdog pedons. 


\section{REFERENCES}

Carter, B.J., and E.J. Ciolkosz. 1980. Soil temperature regimes of the central Appalachians. Soil Sci. Soc. Am. J. 44: 1052-1058.

Delp, C.H. 1998. Soil Survey of Webster County, West Virginia. USDA-Natural Resources Conservation Service, Washington, DC

Flegel, D.G. 1999. Soil Survey of Pocahontas County, West Virginia. USDA-Natural Resources Conservation Service, Washington, DC.

Soil Survey Staff, 1998. Keys to Soil Taxonomy, $8^{\text {th }}$ edition, USDA-Natural Resources Conservation Service. 


\section{CHAPTER FIVE}

\section{SOIL AND VEGETATION ORGANIC CARBON OF THE SERIES}

\section{INTRODUCTORY REMARKS}

The purpose of this chapter is to present the $\mathrm{C}$ data for both the soils and biomass that were measured, and also to explore their potential relationships. This will allow subsequent discussions of other site characteristics in the context of SOC, vegetation organic carbon (VOC), and productivity as indicated by biomass measurements or fertility concerns at the sites.

\section{BIOMASS RESULTS}

The total vegetative biomass (including above and below-ground, and DWD) among the series ranged from 159 to $297 \mathrm{Mg} \mathrm{ha}^{-1}$ (Table 5.1). The average of $159 \mathrm{Mg} \mathrm{ha}^{-1}$ for the Blackwater series (only two sites) was far below the next-lowest mean biomass density for the more extensive series, which was MWD Gauley $\left(236 \mathrm{Mg} \mathrm{ha}^{-1}\right)$. No significant differences were found among the means of the 4 major series, despite the fact that the inceptisols support a very different forest type from the spodosols (northern hardwoods versus spruce, respectively). The northern hardwood-dominated Mandy and Snowdog have the highest biomass densities, 297 and $287 \mathrm{Mg} \mathrm{ha}^{-1}$, respectively. The individual components of site biomass are not significantly different among the series. 
Aboveground site biomass ranged from 129 to $263 \mathrm{Mg} \mathrm{ha}^{-1}$ (Table 5.2), following the same distribution described above. Utilizing equations for above-ground biomass estimation for trees, seedlings, and shrubs, 81 percent of the total site vegetation biomass estimates were aboveground. The above-ground data are provided for the purpose of comparing the biomass estimates of these sites to others from similar forests. As above, the biomass at the Blackwater sites seems anomalously low.

The biomass data for all classes (e.g. herbaceous, DWD, etc.) are provided by pedon site for each series in Appendix D. Individual sites varied considerably in total site (or aboveground) biomass. The lowest total biomass density occurred at site 093001 (Blackwater), which had less than $130 \mathrm{Mg} \mathrm{ha}^{-1}$. In striking contrast, the Mandy site 093004 biomass estimate is over $360 \mathrm{Mg} \mathrm{ha}^{-1}$. 
Table 5.1. Biomass of the major frigid series.

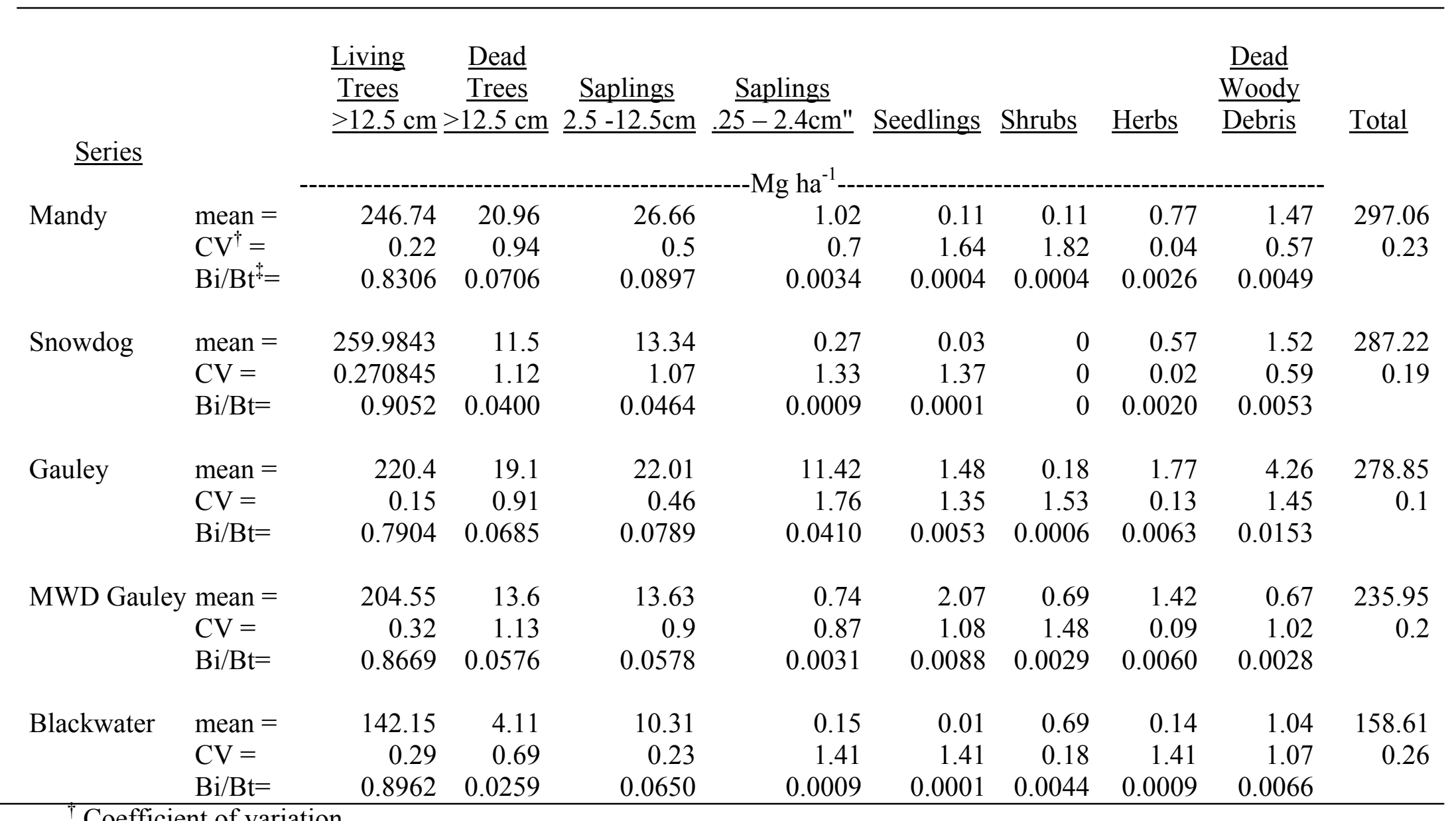

\footnotetext{
Coefficient of variation

Ratio of individual biomass component to the total biomass per area.
} 
Table 5.2. Above-ground biomass of the series.

\begin{tabular}{|c|c|c|c|c|c|c|c|c|c|}
\hline \multirow[b]{2}{*}{$\underline{\text { Series }}$} & \multicolumn{5}{|c|}{------------------Tree species (standing)-------------- } & & \multicolumn{3}{|c|}{$\underline{\text { Dead }}$} \\
\hline & $\underline{\text { Living }}$ & $\underline{\text { Dead }}$ & $\underline{2.5-12.5}$ & $\frac{\frac{.25-2.4}{\mathrm{~cm} \mathrm{DBH}}}{-\mathrm{Mg} \mathrm{ha}^{-1}--}$ & $\underline{\text { Seedlings }}$ & $\underline{\text { Shrubs }}$ & $\underline{\text { Herbs }}$ & $\frac{\text { Woody }}{\text { Debris }}$ & $\underline{\text { Total }}$ \\
\hline Mandy & 199.79 & 16.97 & 21.58 & 0.82 & 0.09 & 0.09 & 0.77 & 1.47 & 241.59 \\
\hline Snowdog & 210.51 & 9.31 & 10.80 & 0.22 & 0.02 & 0.00 & 0.57 & 1.52 & 232.96 \\
\hline Gauley & 178.46 & 15.46 & 17.82 & 9.24 & 1.20 & 0.14 & 1.77 & 4.26 & 228.37 \\
\hline MWD Gauley & 165.62 & 11.01 & 11.03 & 0.60 & 1.68 & 0.56 & 1.42 & 0.67 & 192.60 \\
\hline Blackwater & 115.10 & 3.33 & 8.35 & 0.12 & 0.01 & 0.56 & 0.14 & 1.04 & 128.65 \\
\hline
\end{tabular}


Among the various components of biomass, living sawtimber-sized trees (greater than $12.5 \mathrm{~cm} \mathrm{DBH}$ ) comprised from 79 to 92 percent of total site biomass (Tables 5.1 and 5.2). Sawtimber, saplings, and dead sawtimber account for 90 percent or more of the total biomass for each series. There was great variation in seedling, herb, and DWD biomass, both within and among sites and series. The herb layer, in particular, yields tenuous data due to the complicating presence of mosses and the variation in the time of sample collection. However, some general trends are evident, in that the spodosol sites (sprucedominated) have relatively larger portion of site biomass distributed among the seedling vegetation, and appear to have higher herb biomass. The herb biomass was biased on these sites by the fact that mosses were much more prevalent in the shade of the evergreens than on the hardwood sites. Moss biomass collection unfortunately entailed the inadvertent measurement of Oi and/or DWD encrusted in the moss fibers - which was discovered only after drying. While the Blackwater sites have much lower biomass than the others, there is no clear indication in the distribution among the biomass classes that indicate an earlier successional stage or other disturbance, compared to the other series.

Though not diverse compared to other Appalachian forest ecosystems, there were notable differences in species occurrence among the sites of the different series in this study. The Mandy and Snowdog sites had far more occurrences of more overstory species than did the Blackwater, MWD Gauley, and Gauley series (Table 5.3). The biomass of sawtimbersized trees are detailed for the sites by species in Appendix D. All sites were dominated by either red maple and yellow birch (Mandy, Snowdog, Blackwater), or red spruce and 
hemlock (MWD Gauley and Gauley). Numerous dead yellow poplars (Liriodendron tulipifera L.) were observed at the Blackwater 093001 site.

Unfortunately, herb species were not consistently documented among the sites. It was noticed during the mapping and sampling of these areas that the adjacent (lower) areas of soils formed from Mauch Chunk (Mississippian) parent materials are far more diverse in botanical species. This was true of all forest layers, from herbaceous to sawtimber vegetation. This difference is generally attributed to differences in soil fertility resulting from the Pottsville (Pennsylvanian) and Mauch Chunk parent materials.

\section{Table 5.3. Sawtimber $(>12.5 \mathrm{~cm})$ species occurrence for the series.}

$\underline{\text { Series }} \quad \underline{\text { Tree species }}$

Blackwater $\quad$ Yellow birch, red maple, red spruce

Gauley $\quad$ Red spruce, hemlock, red maple, yellow birch

MWD Gauley $\quad$ Red spruce, hemlock, red maple, yellow birch

Mandy $\quad$ Yellow birch, red maple, black cherry, hemlock, Am. beech (Fagus americana), red spruce, red oak, serviceberry, striped maple (Acer pennsylvanicum), sweet birch (Betula lenta)

Snowdog Yellow birch, red maple, black cherry, hemlock, Am. Beech, red spruce, red oak, serviceberry, sugar maple (Acer saccharum), cucumber magnolia (Magnolia acumenata) 


\section{SOIL ORGANIC CARBON RESULTS}

The average SOC stocks of the series ranged from 11.3 for Gauley to $18.8 \mathrm{~kg} \mathrm{~m}^{-2}$ for Snowdog (Table 5.4). For the most part, variability within each series was relatively low, compared to other studies, where coefficients of variations (CV's) typically exceeded 0.30 (Arnold, 1995). One Gauley pedon was noticeably lower in SOC stocks (7.06 kg $\mathrm{m}^{-2}$ ), accounting for the high $\mathrm{CV}$ for this series. This particular pedon had a very high percentage of rock fragments in a relatively thin spodic horizon, which accounted for its low SOC storage. Significant differences among series are detailed and discussed in the following chapter. Soil and vegetation organic carbon are shown by site in Table 5.5.

\section{Table 5.4. Soil organic carbon stocks of the series ${ }^{\dagger}$.}

$\begin{array}{lrl}\text { Series } & \frac{\mathrm{SOC}}{\left(\mathrm{kg} \mathrm{m}^{-2}\right)} & \\ \text { Blackwater } & 15.19 \mathrm{a} & 0.05 \\ \text { Gauley } & 11.30 \mathrm{a} & 0.27 \\ \text { MWD Gauley } & 13.02 \mathrm{a} & 0.12 \\ \text { Mandy } & 12.85 \mathrm{a} & 0.15 \\ \text { Snowdog } & 18.78 \mathrm{~b} & 0.09\end{array}$

$\dagger$ Differing letters denote significant difference, $\alpha<0.01$. + Coefficient of variation. 
Table 5.5. Soil, vegetation, and total site organic carbon by pedon.

\begin{tabular}{|c|c|c|c|c|c|}
\hline$\underline{\text { Series }}$ & $\underline{\text { Pedon ID }}$ & $\underline{\mathrm{SOC}}$ & $\underline{\mathrm{VOC}}$ & $\underline{\text { Site OC }}$ & $\underline{\text { SOC/Site OC }}$ \\
\hline \multirow[t]{4}{*}{ Mandy } & 083005 & 13.94 & 15.20 & 29.14 & 0.48 \\
\hline & 083007 & 11.93 & 16.13 & 28.07 & 0.43 \\
\hline & 093004 & 14.94 & 18.12 & 33.06 & 0.45 \\
\hline & 093005 & 10.59 & 10.11 & 20.70 & 0.51 \\
\hline \multirow[t]{4}{*}{ Snowdog } & 083001 & 20.87 & 12.45 & 33.32 & 0.63 \\
\hline & 093006 & 17.86 & 11.66 & 29.52 & 0.61 \\
\hline & 083004 & 19.45 & 15.19 & 34.64 & 0.56 \\
\hline & 093008 & 16.94 & 17.29 & 34.23 & 0.49 \\
\hline \multirow[t]{4}{*}{ Gauley } & 075001 & 11.59 & 13.78 & 25.37 & 0.46 \\
\hline & 075002 & 14.22 & 16.04 & 30.26 & 0.47 \\
\hline & 093007 & 12.31 & 13.57 & 25.88 & 0.48 \\
\hline & 083003 & 7.05 & 12.74 & 19.80 & 0.36 \\
\hline \multirow[t]{4}{*}{ MWDGauley } & 083006 & 11.82 & 14.34 & 26.17 & 0.45 \\
\hline & 083002 & 14.41 & 12.55 & 26.95 & 0.53 \\
\hline & 093002 & 14.35 & 8.66 & 23.02 & 0.62 \\
\hline & 093003 & 11.49 & 11.92 & 23.41 & 0.49 \\
\hline \multirow[t]{2}{*}{ Blackwater } & 083008 & 15.47 & 9.38 & 24.84 & 0.62 \\
\hline & 093001 & 14.67 & 6.49 & 21.15 & 0.69 \\
\hline
\end{tabular}


For all series, SOC decreased exponentially with depth (Figure 5.1). The spodosols exhibited increases in SOC rising from around 0.2 to 0.5 percent in the albic horizons, to 2 to 4 percent or more in the spodic horizons, otherwise following the SOC reduction with depth common to all series. Spodic horizons are significant SOC reservoirs. Gauley and MWD Gauley spodic horizons contain 30 and 24 percent of the average total pedon SOC, respectively.

There is considerable SOC in the upper horizons of these series. The epipedons ( $\mathrm{O}$ and $\mathrm{A}$ horizons) of the series were responsible for 47 to 56 percent of total pedon carbon storage. This is somewhat more than that documented for some other temperate forest soils (Bliss et al., 1995; Eswaran et al., 1995; Kern, 1994), and is somewhat surprising in view of the far greater thickness and $\mathrm{Db}$ of lower horizons (Appendix B).

Subsoil and substrata (not including spodic) horizons generally stored about 25 (spodosols) to 50 percent (inceptisols) of total SOC in the pedons. The cambic horizons of these series often had in excess of 1 percent OC (Appendix B). This is a considerably greater SOC concentration than is typical for argillic or cambic horizons in similar mesic soils in West Virginia (unpublished data of the NRCS-NSSL, used in the following chapter).

\section{DICHROMATE VERSUS TOTAL (COMBUSTION) CARBON}

Among the pedons, combustion carbon values are usually slightly lower than dichromate $\mathrm{C}$ in the upper soil horizons, and slightly higher in the lower soil horizons, (Appendix B). 
The resulting distributions of carbon with depth are very similar (Figure 5.2). Data were available for all horizons of 12 pedons. For these pedons, SOC estimates stemming from the differing $\mathrm{C}$ estimation methods were obtained as follows: Combustion $\mathrm{C}$ measurements were used only for the mineral soil horizons, and dichromate $\mathrm{C}$ measurements were used for $\mathrm{O}$ horizons - the goal being to obtain a maximum estimate of the SOC which would include charcoal and carbolithic fragments. The resulting pedon SOC estimates are an average of $1.6 \mathrm{~kg} \mathrm{~m}^{-2}$ (about 10 percent) greater than those using only dichromate carbon extraction. It is unclear why combustion values would be lower than dichromate values in any horizon. Some combustion C data are blatantly inconsistent, as evidenced in Mandy pedon 083007 (Appendix B), and were not used. It seems logical that where charcoal exists, it would be more likely to be in the upper soil horizons, and that carbolithic materials would be more likely to be encountered in the lower (less weathered) horizons. If this is true, then these data seem to indicate that the combustion method of SOC extraction was less successful at identifying charcoal carbon than was the dichromate extraction. Combustion does appear to be more effective at extracting carbolithic SOC. The Walkley-Black method is used for all SOC estimates outside this section.

\section{TOTAL SITE ORGANIC CARBON (SOIL AND VEGETATION)}

It is interesting to look at the total site carbon in relation to site VOC and SOC. The vegetative biomass estimates presented in Table 5.1 above were simply multiplied by 0.5 to obtain VOC (Birdsey, 1992 a, b; Brown and Lugo, 1982; Grigal and Ohman, 1992; Wharton and Griffith, 1993;1998). The sites have total organic C stocks ranging from 23 
to $33 \mathrm{~kg} \mathrm{~m}^{-2}$ (Figure 5.3). With the exception of Blackwater, there is no distinct case of SOC or VOC dominating the total site OC. The very low biomass estimate for the Blackwater sites results in a clearly dominant portion of site OC coming from Soil organic carbon.

\section{RELATIONSHIPS OF SOC AND BIOMASS}

The SOC, VOC, and total site OC are presented by pedon in Table 5.5. On average, SOC constitutes 52 percent of the total site OC, but it ranges from 36 to 69 percent among the sample locations. Among the series, Snowdog, MWD Gauley, and Blackwater had over 50 percent of site OC in SOC. Soil organic carbon and biomass $\mathrm{C}$ amounts are not clearly related among the sample sites (Figure 5.4). Despite our efforts to reduce variation by selecting sites of comparable silvicultural histories, and on similar landforms within each series, our level of control was insufficient to elucidate relationships of series and biomass amounts. 


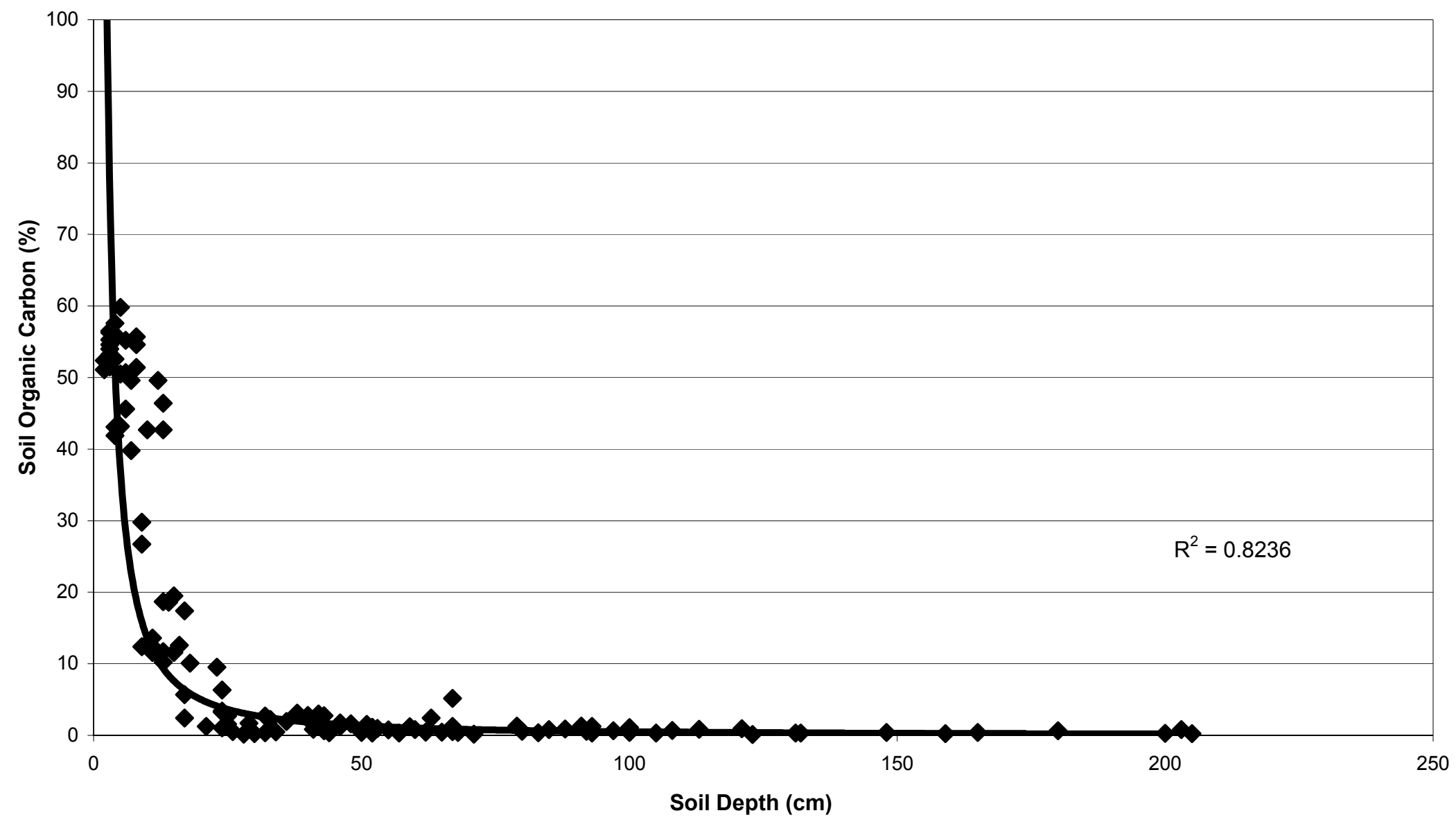

Figure 5.1. Relationship of soil organic carbon to soil depth for the series. 


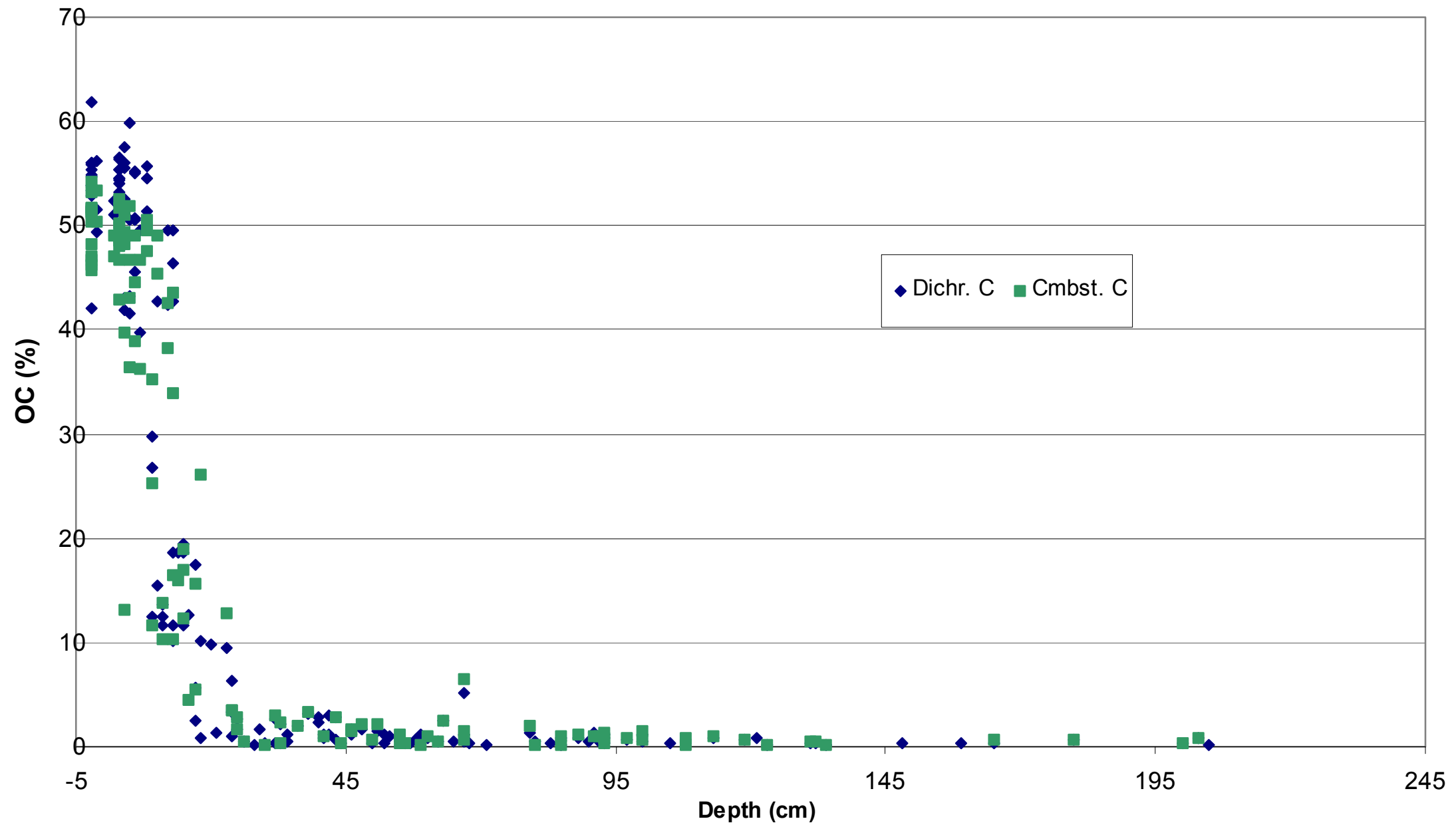

Figure 5.2. Dichromate andcombustion estimates of SOC by depth for the series (all horizons). 


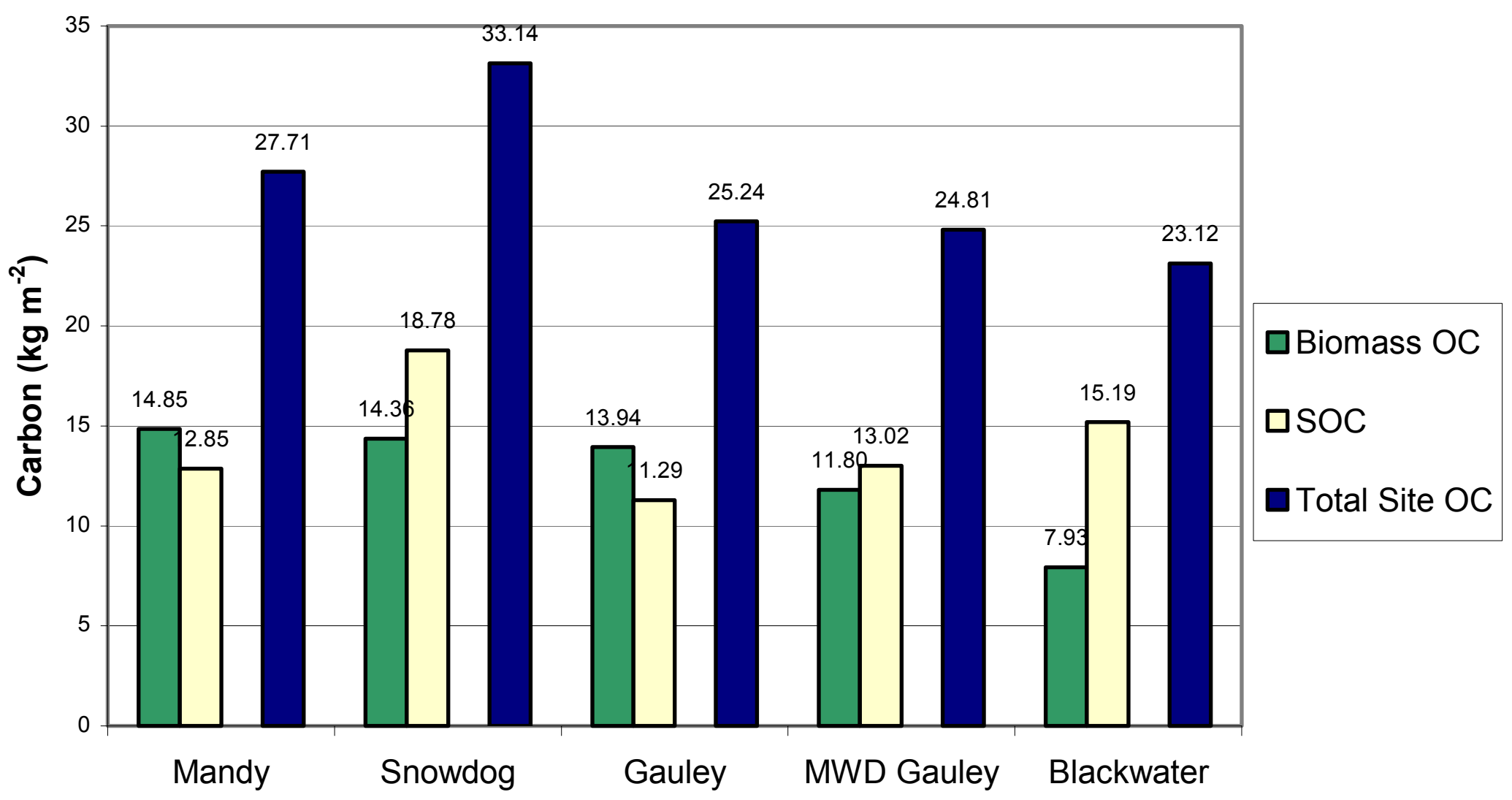

Figure 5.3. Vegetation, soil, and total organic carbon stocks of the series. 


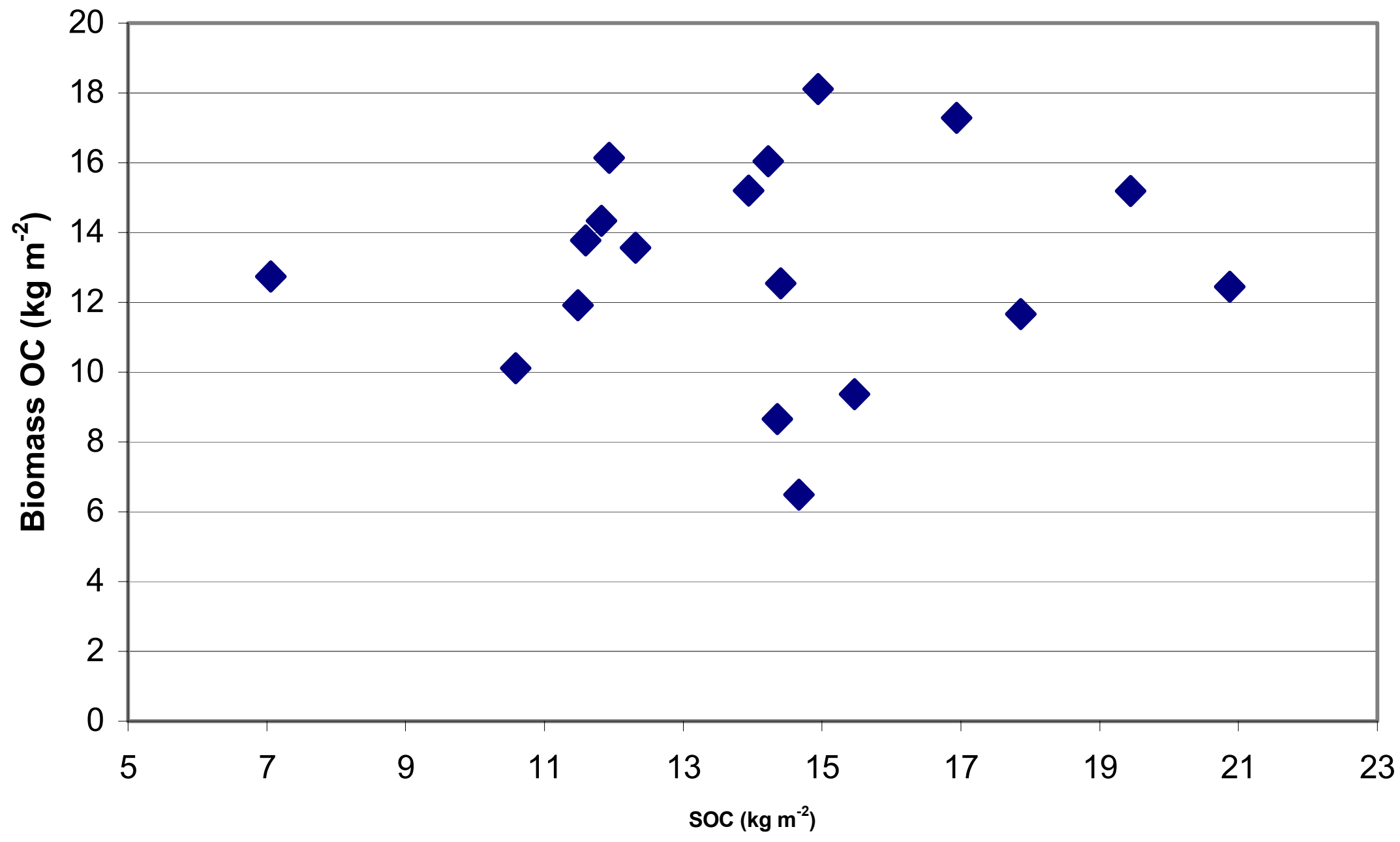

Figure 5.4. Soil and vegetation organic carbon for all sites. 


\section{RELATIONSHIPS OF SOC AND VOC STOCKS TO OTHER SOIL/SITE CHARACTERISTICS}

There are some interesting trends among the relationships of nutrient levels to SOC and VOC stocks. (Note: the relationships of SOC concentrations to exchangeable and total Ca concentrations are explored in Chapter 8). Whole-pedon nutrient pools are (inconsistently) correlated with SOC stocks (Table 5.6). They are generally weakly (negatively) correlated to VOC amounts. Exchangeable K, and exchangeable and total $\mathrm{Mg}$ show the strongest relationship to SOC, but are negatively associated with biomass carbon. The negative correlation of VOC with total $\mathrm{Ca}$ is largely a function of the relatively large $\mathrm{Ca}$ pool in the low-biomass Blackwater sites. Excluding two pedons which had total Ca pools that were 2 to 5 times higher than the others, the correlation coefficient drops to -0.15 . With regard to pedon $\mathrm{P}$ stocks, only the relationship of SOC to total $\mathrm{P}$ shows anything resembling a trend. Any associations of total $\mathrm{P}$ to biomass $\mathrm{C}$, and of SOC or biomass $\mathrm{C}$ to exchangeable $\mathrm{P}$ are unclear. If overall biomass productivity on these sites is related to the overall quantities or availability of these nutrients, it is not evident from these data. Although it is plausible that other aspects of productivity, (such as merchantable volumes, stem form, and defects) may be affected by these soil characteristics, they are beyond the scope of this study. 
Table 5.6. Summary of linear correlations ${ }^{\dagger}$ of SOC and VOC stocks to soil nutrient stocks and site characteristics.

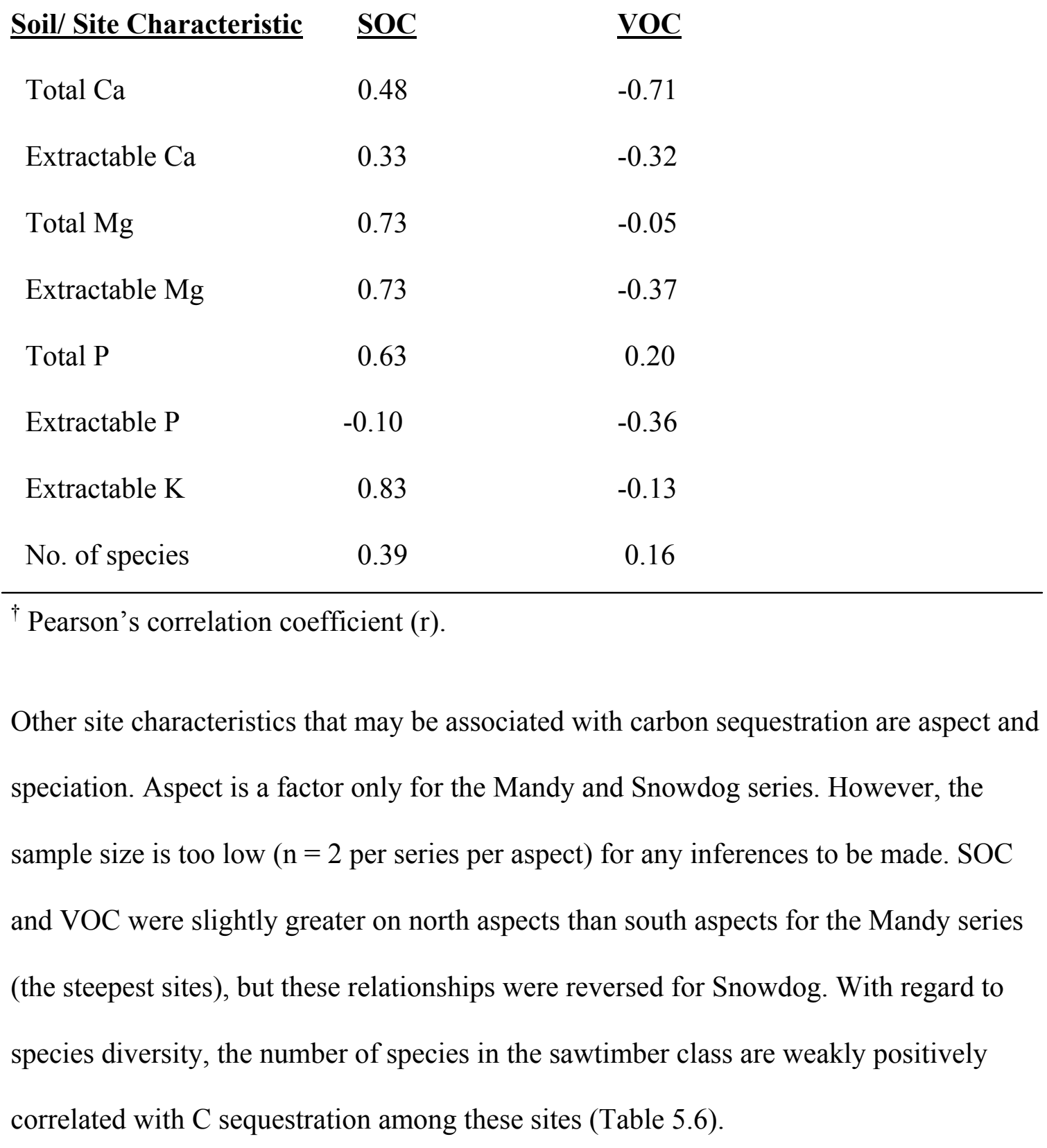

The relationship of the number of sawtimber-size species (i.e. diversity) to the amounts of nutrients is not well demonstrated. Although weak positive associations exist, 
particularly when the site with limestone contamination is omitted, the relationships among these series are equivocal at best.

\section{REFERENCES}

Birdsey, R.A.(a) 1992. Changes in forest carbon storage from increasing forest area and timber growth.. p. 23 - 39. In Sampson, R.N. and D. Hair (ed.) Forests and global change. Vol. 1: Opportunities for increasing forest cover. American Forests, Washington DC.

Birdsey, R.A.(b) 1992. Carbon storage and accumulation in United States forest ecosystems. USDA Forest Service GTR WO-59.

Bliss, N.B., S.W. Waltman, and G.W. Peterson. 1995. p. 275 -295 In R. Lal et al. (ed.) Soils and global change. CRC Press, Boca Raton, FL.

Brown, S.L., and A.E. Lugo. 1982. The storage and production of organic matter in tropical forests and their role in the global carbon cycle. Biotropica 14: 161-187.

Eswaran, H., I. Van den Berg, P.Reich, and J. Kimble. 1995. Global Soil Carbon Resources. p. 27-43. In R. Lal et al. (ed.) Soils and global change. CRC Press, Boca Raton, FL. 
Grigal, and L.F. Ohmann. 1992. Carbon storage in upland forests of the lake states. Soil Sci. Soc. Am. J. 56: 935-943.

Kern, J.S. 1994. Spatial patterns of soil organic carbon distribution in the contiguous United States. Soil Sci. Soc. Am. J. 58: 439-455.

Wharton, E.H., and D.M. Griffith. 1993. Methods to estimate total forest biomass for extensive forest inventories: applications in the Northeastern U. S. USFS Res. Bull. NE681. Northeastern Res. Sta., Radnor, PA 52 p.

Wharton, E.H., and D.M. Griffith. 1998. Estimating total forest biomass in Maine, 1995. USFS Res. Bull. NE-142. Northeastern Res. Sta., Radnor, PA. 50 p. 


\section{CHAPTER SIX}

\section{SOIL MICROBIAL BIOMASS CARBON}

\section{AMOUNTS AND COMPARISONS}

Soil microbial biomass carbon averages from 0.5 to 33.0 percent (of the fine-earth fraction, by weight) for the horizons sampled (Table 6.1). The Oe horizons had much higher average SMBC estimates than the mineral horizons, reflecting the much higher total SOC of the organic horizons. Interestingly, SMBC accounted for a substantial portion of the total SOC in the horizons sampled (Table 6.1). Again, the Oe horizons in particular are notable, where SMBC accounted for up to 65.4 percent of the total SOC (site 093004). More detailed data from SMBC analyses are presented in Appendix E. The SMBC percentage of total SOC is much greater than some ranges previously reported. Horwath (1993) attributed only 1 to 2 percent of SOC to SMBC in an hybrid poplar forest soil. It is impossible to say if all $\mathrm{C}$ analyzed as $\mathrm{SMBC}$ is in fact from soil biota (i.e. nonvegetative biota). One possible source of non-microbial C in the Oe horizons is from fine roots, which may well be released during the fumigation and extraction. Such fine root matter is typically incorporated into bulk soil samples, as it is physically impractical or impossible to remove it (Smith, 2001). 
Table 6.1. Soil microbial biomass carbon in two horizons of the Gauley and Mandy series.

\begin{tabular}{|c|c|c|c|c|c|}
\hline$\underline{\text { Series }}$ & $\underline{\text { Site }}$ & Horizon & $\underline{\text { SMBC }^{\dagger}}$ & $\underline{\mathbf{S O C}}^{\dagger}$ & $\underline{\mathrm{SMBC} / \mathrm{SOC}}$ \\
\hline Gauley & 083003 & Oe & $17.7(0.38)^{\ddagger}$ & 55.7 & 0.32 \\
\hline Gauley & 083003 & $\mathrm{AE}$ & $0.6(0.39)$ & 2.4 & 0.24 \\
\hline Gauley & 093007 & $\mathrm{Oe}$ & $9.4(0.48)$ & 55.2 & 0.17 \\
\hline Gauley & 093007 & $\mathrm{AE}$ & $1.4(0.86)$ & 11.6 & 0.12 \\
\hline Mandy & 093004 & Oe & $33.0(0.34)$ & 50.5 & 0.65 \\
\hline Mandy & 093004 & A & $1.1(0.53)$ & 19.5 & 0.06 \\
\hline Mandy & 093005 & $\mathrm{Oe}$ & $13.3(0.21)$ & 43.2 & 0.31 \\
\hline Mandy & 093005 & $\mathrm{~A}$ & $0.5(0.71)$ & 11.6 & 0.04 \\
\hline
\end{tabular}

The Mandy and Gauley series present very different environments for SMB activity, and this is indicated by the distributions of SMBC in the Oe and A (or AE) horizons. Within the two series, $\mathrm{O}$ horizons had significantly greater SMBC than did the underlying mineral horizons (Table 6.2). However, the differences in SMBC between the series were equivocal. While one might expect higher SMB activity in the organic matter from northern hardwoods (Mandy) than that in Oe horizon formed from dominantly spruce and hemlock litter (Gauley), the data here are insufficient to confidently declare a significant difference. 


\begin{tabular}{lr} 
Comparison & $-\underline{\mathrm{P}^{\dagger}}$ \\
Gauley O $>$ A & $<0.01$ \\
Mandy O $>$ A & $<0.01$ \\
Mandy O $>$ Gauley O & 0.45 \\
Mandy A $>$ Gauley A & 0.08 \\
\hline${ }^{\dagger}$ Single factor ANOVA. & \\
\hline
\end{tabular}

\section{DISTRIBUTIONS AND RELATIONSHIPS TO OTHER SOIL PARAMETERS}

The relationships of SMBC to other soil chemical parameters may be instructive as to the possible causes of differences between horizons and series. Total SOC for the horizons is correlated to SMBC (Figure 6.1). This relationship is probably due to the increased substrate (SOM) quantity and quality indicated by higher SOC content. Presumably, the SOM in the hemic material of the Oe horizon is much less humified and therefore more decomposable than the SOM of the mineral horizons. This relationship is further reinforced by the positive correlation of SMBC with the base saturation of effective cation exchange capacity and $\mathrm{pH}$ (Figures 6.2 and 6.3, respectively). 


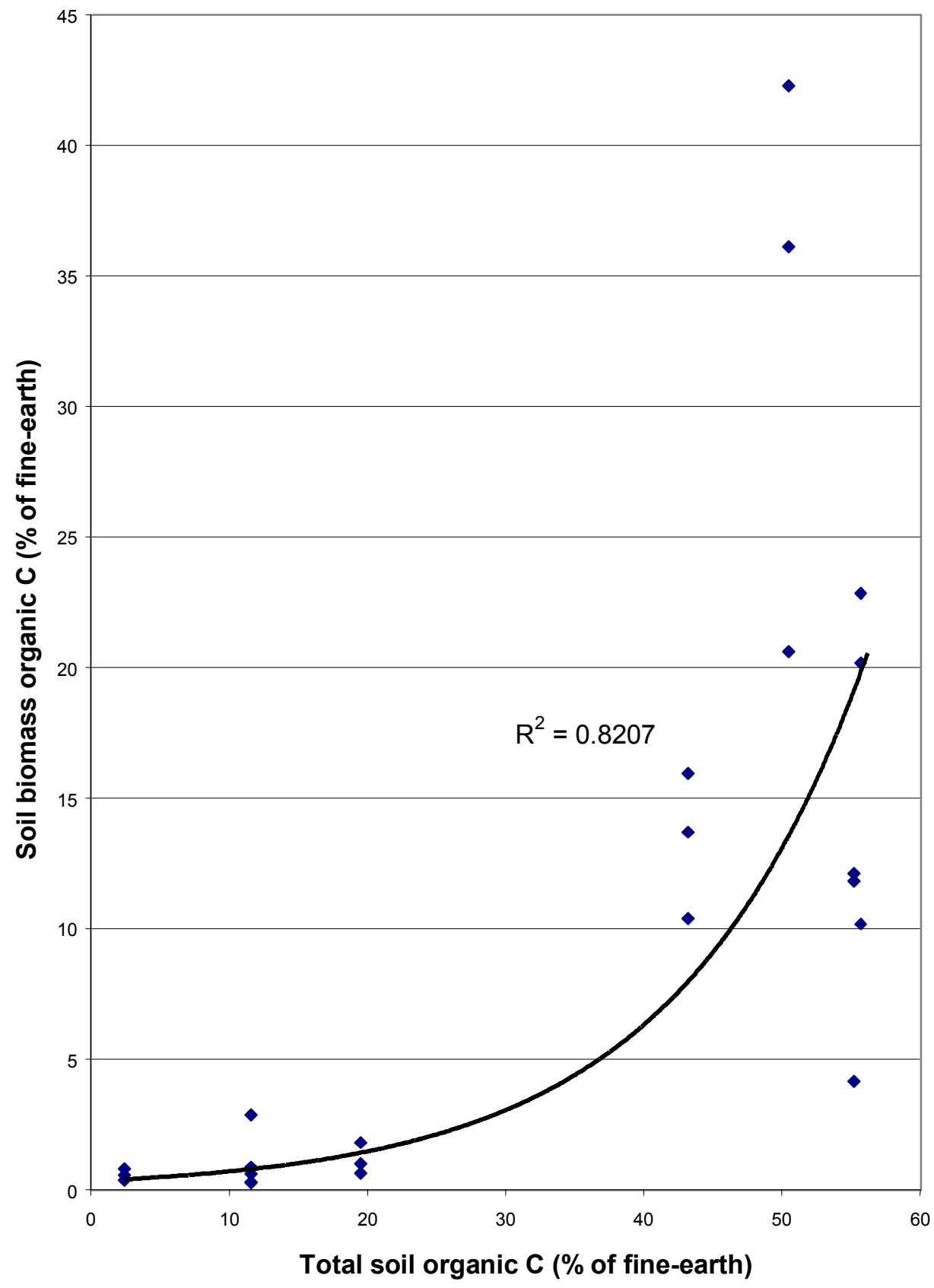

Figure 6.1 Relationship of total soil and soil biomass organic C for Gauley and Mandy series. 


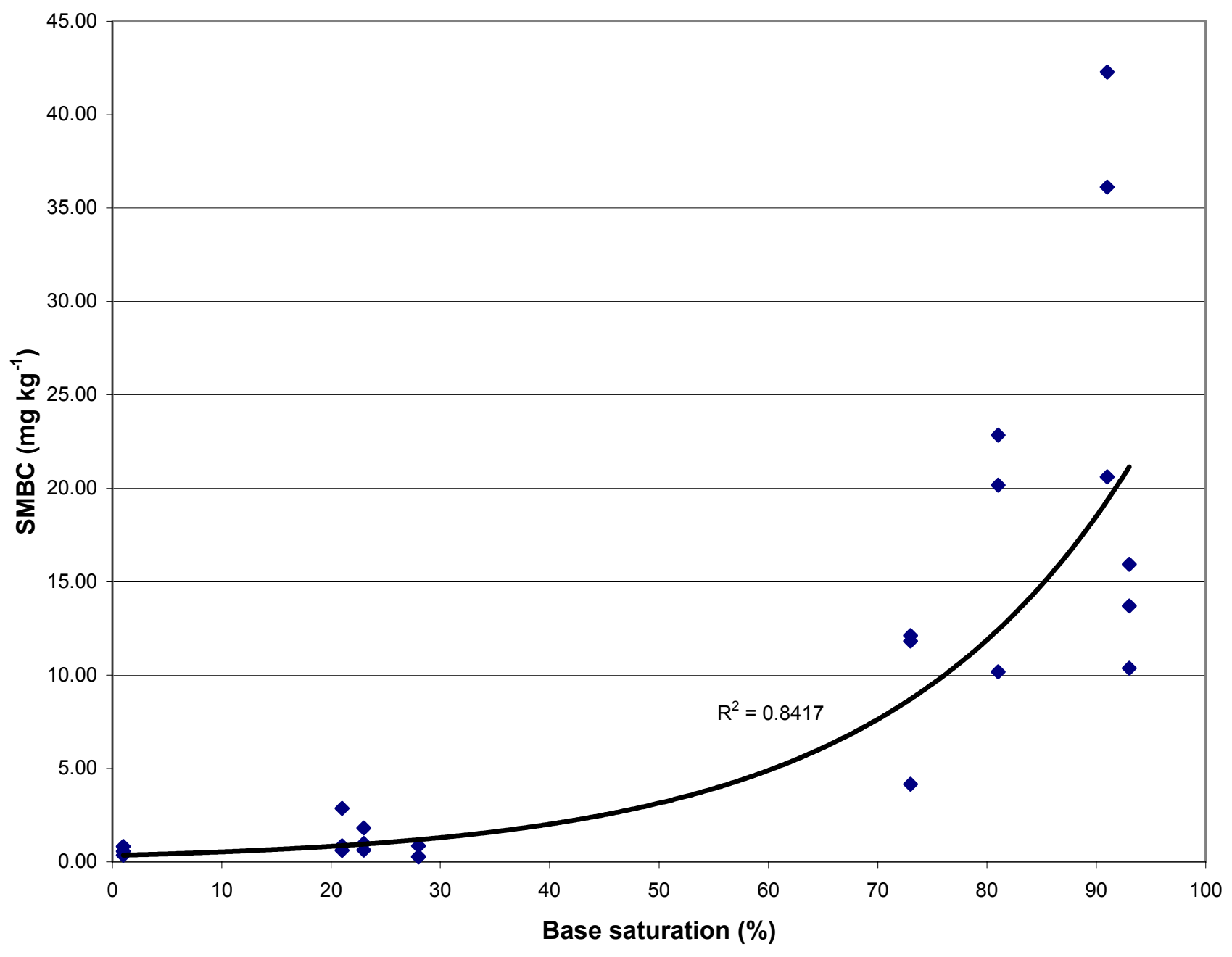

Figure 6.2 Relationship of soil microbial biomass carbon to base saturation of ECEC for the Gauley and Mandy series. 


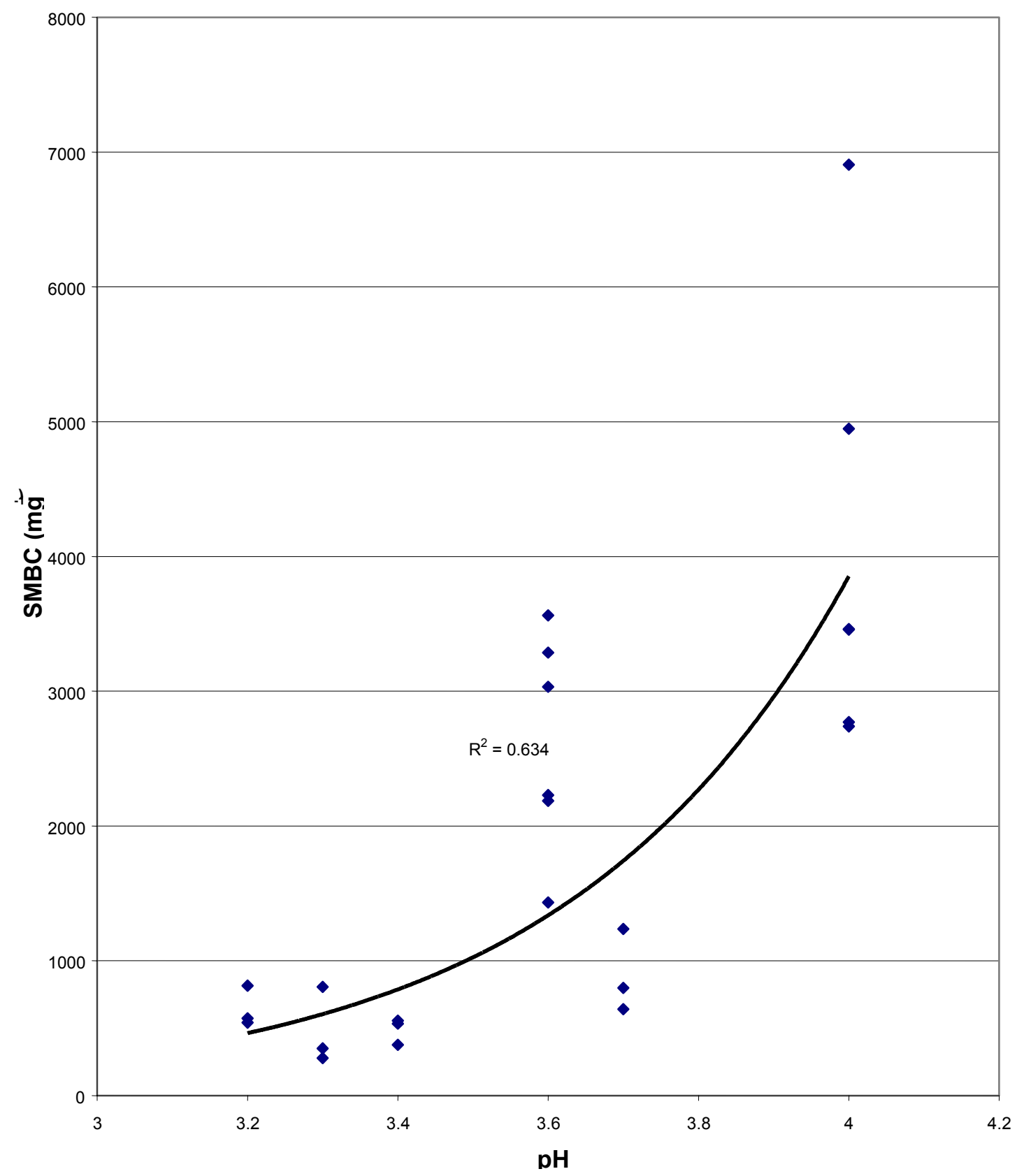

Figure 6.3 Relationship of soil microbial biomass $\mathrm{C}$ and soil $\mathrm{pH}$ (in water) for the Gauley and Mandy series. 
These correlations of SMBC and other soil chemical parameters are interesting in that the nature of the relationship is open to considerable speculation. Are soil biota simply more active and functional as a direct consequence of increased nutrient supply and the decomposability of the soil organic matter? Clearly, decomposer populations increase with increasing substrate availability (e.g. Paul and Clark, 1996). However, is it correct to see negative relationships correlating with acidity parameters such as $\mathrm{Al}$ saturation (Figure 6.4)? Acidification and subsequent Al solubility have been shown to be detrimental to P uptake function of fungi and bacteria (Jongbloed et al., 1992) and growth (Paul and Clark, 1996; Thomson and Medve, 1984). The A and AE horizons here have very low $\mathrm{pH}$ and high $\mathrm{Al}$ saturation, which would presumably restrict or eliminate certain genera.

It seems likely that, just as there are many genera and trophic levels represented by the SMBC, there are simultaneous examples of stimulus and inhibition in the relationships illustrated here. Certainly, these data establish trends and relationships that beg further study. If more mineral horizons were studied in these soils, and more were known about the soil biota composition - then inferences about fertility and acidity impacts might be made. 


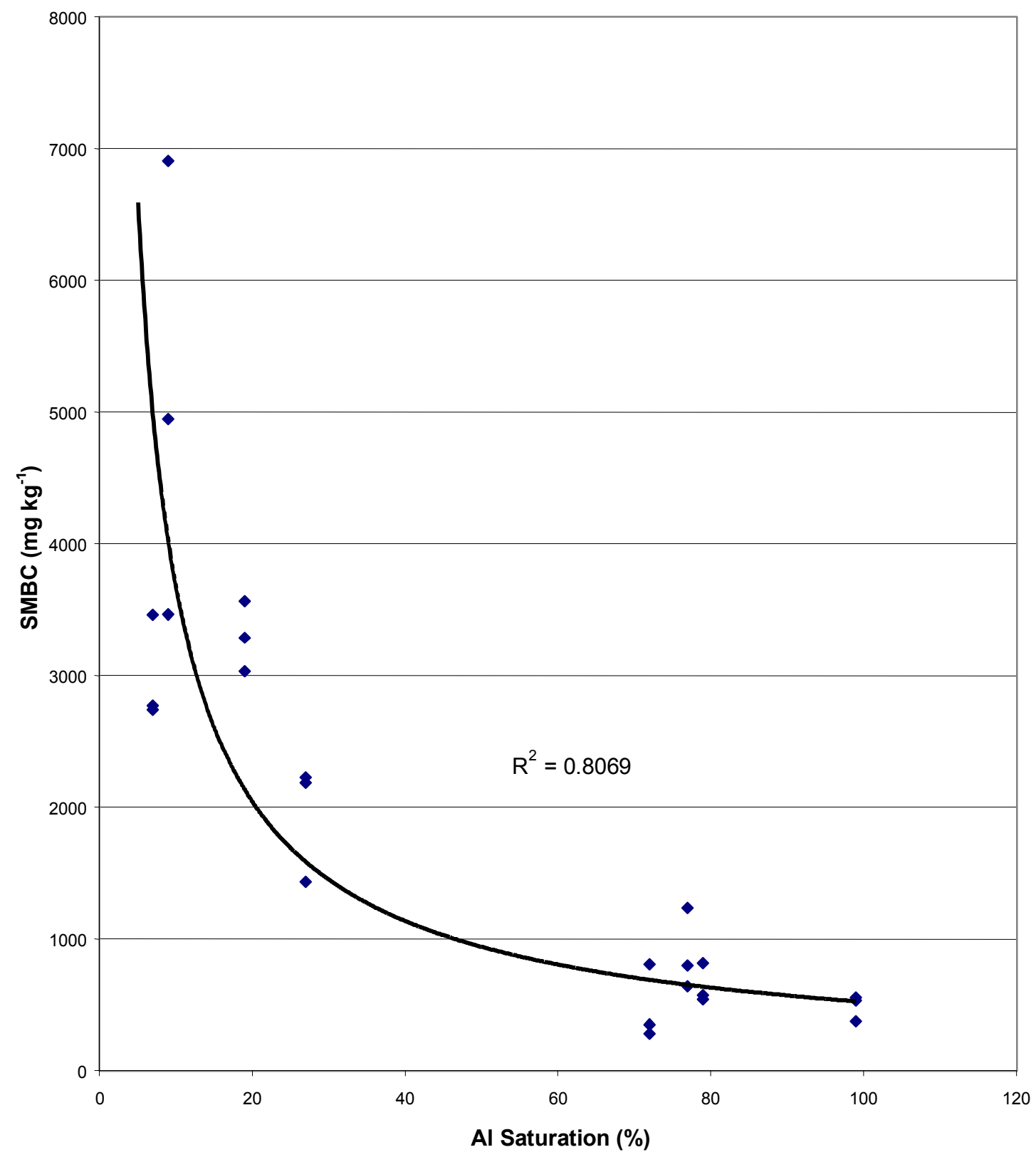

Figure 6.4 Relationship of soil microbial biomass $\mathrm{C}$ and $\mathrm{Al}$ saturation for the Gauley and Mandy series. 
The implications of these data for SOC sequestration and plant nutrient dynamics are worth exploring. Given the low $\mathrm{pH}$ and high $\mathrm{Al}$ saturation of the mineral soils examined, and their significantly lower levels of SMBC, there appears to be an excellent environment for SOM accumulation. Relative to its mesic analogue (Gilpin), the Mandy series sequesters more SOC (Chapter 7). Whether this is strictly a function of a cooler environment affecting vegetation types, which affect soil acidity in turn; or whether it is a more inherent effect of soil acidity on SOC retention is not clear. It is tempting to speculate that in such acidified soil, where ECEC is low and Al saturation is high, that SOC accumulation presents the most auspicious strategy for nutrient retention in a system where base cations and $\mathrm{P}$ may be limiting.

\section{REFERENCES}

Horwath, W.R. 1993. The dynamics of carbon, nitrogen, and soil organic matter in a Populus plantation. Ph.D. Thesis. Michigan State University, East Lansing.

Jongbloed, , R.H., M.W.A. Tosserams, and G.W.F.H. Borst-Pauwels. 1992. The effect of aluminum on phosphate uptake by three isolated ectomycorrhizal fungi. Plant and Soil. 140:167-174.

Paul, E.A., and F.E. Clark. 1996. Soil Biology and Biochemistry. Academic Press, San Diego, CA 340 p. 
Smith, G.R. 2001. Toward an efficient method for measuring total organic carbon stocks in forests. p. 293-310. In Lal, et al. (eds.) Assessment methods for soil carbon. Lewis Publishers. Boca Raton, Florida.

Thompson, G.W., and E. Medve. 1984. Effect of aluminum and manganese on ectomycorrhizae. J. Appl. Env. Micro. 48:556-560. 


\section{CHAPTER SEVEN}

\section{A COMPARISON OF SOIL ORGANIC CARBON STOCKS OF MAJOR FOREST SOILS ON THE ALLEGHENY PLATEAU OF WEST VIRGINIA}

\section{INTRODUCTION}

Estimates of soil organic carbon (SOC) pools are important and evolving components of models used for global climate change prediction (Lal et al., 1995). Reliable data quantifying organic carbon sequestered in soils are dependent on knowledge concerning several pools and processes (Arnold, 1995). Recent research indicates a need for increased focus on "forest floor" $(\mathrm{O})$ horizons, as well as improving the bulk density $(\mathrm{Db})$ estimates of horizons which are high in SOC (Eswaran et al., 1995; Homann et al., 1995; Huntington et al.; 1989, Snyder and Pilgrim, 1985). Furthermore, SOC stocks and distribution are an acknowledged data gap in the Appalachian region for models that rely on SOC estimates (Grossman, 1991).

Eswaran et al. (1995) outlined many of the difficulties associated with global SOC estimates. Similar difficulties have arisen when more localized estimates have been attempted (Arnold, 1995). Presently, SOC estimates for the United States (US) are based on information derived either from pedon data compiled by the USDA-Natural Resources Conservation Service (NRCS) (Eswaran et al., 1993,1995; Kern, 1994; Post et al., 1982) or from NRCS Soil Interpretation Records (SIRs) (Bliss et al., 1995). These studies 
incorporate various spatial strategies utilizing either ecological or soil-based maps, and their estimates of SOC pools for this study area vary widely. Those data do not contain information about $\mathrm{O}$ horizons, and all $\mathrm{Db}$ values are based on the clod or core method (Blake and Hartge, 1986).

Bulk density estimates, particularly of stony forest soil surface horizons, are perhaps the most universally vexing source of error in SOC stock estimation (Arnold, 1995; Eswaran, 1993, 1995; Homann et al., 1995; Kern, 1994; Manrique and Jones, 1991; Vincent and Chadwick, 1994). Standard soil survey procedure in the U.S. is to report Db by the clod method (Soil Survey Laboratory Staff, 1992). However, upper soil horizons in this region are commonly high in organic carbon, roots, and rock fragments. This situation is not conducive to obtaining clods which are representative of whole soil bulk density (Curtis and Post, 1964; Vincent and Chadwick, 1994). We have observed that clods taken from upper mineral horizons are usually small and difficult to remove intact. In such situations, only the most coherent structural units with the least voids are obtained, and "difficult" areas (often typical) are avoided. We suspect that these factors make it likely that error is compounded towards overestimation of bulk density for forested epipedons in this region.

In addition to estimating existing SOC stocks, the factors that control carbon sequestration and release warrant study. The influence of climate on SOC pools has been demonstrated at relatively large scales (Jenny, 1980; Post et al., 1982) or across varying pedogenic scenarios within a region (Homann et al., 1995). However, in these studies 
the temperature regime changes are often accompanied by major changes in other soil forming factors. Temperature-related SOC variation between more closely related soils might better elucidate factors determinant of carbon sequestration and ecosystem response to climate change.

The soils of West Virginia (WV) are predominantly forested, and the geomorphic characteristics of the Allegheny Plateau allow the comparison of adjacent, pedogenically analogous soils with mesic and frigid temperature regimes. In this study, we evaluated the SOC stocks of some major forest soil series on the Allegheny Plateau of West Virginia. Our objectives were to determine areal SOC stocks for these extensive series by incorporating $\mathrm{O}$ horizon data and improved $\mathrm{Db}$ estimation, to evaluate if current means of areal estimation of SOC stocks in this region are reasonable and to determine if frigid soils sequester more SOC than their mesic analogues.

\section{MATERIALS AND METHODS}

\section{Study Area and Soils}

The study area occurs in Major Land Resource Areas (MLRA) 125 and 127 on the Allegheny Plateau of West Virginia (USDA, 1981), where areas of mesic and frigid soils occur within short distances of each other. The series from the mesic area range in elevation from about $500 \mathrm{~m}$ to $900 \mathrm{~m}$. The frigid series range from 1100 to $1300 \mathrm{~m}$. The approximate elevation at which mean annual soil temperature (MAST) drops below $8^{\circ} \mathrm{C}$

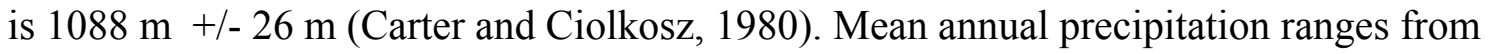


about $1150 \mathrm{~mm}$ to $1400 \mathrm{~mm}$ across the study region, with the higher elevations generally receiving the higher precipitation amounts. Most precipitation falls as rain, and snow cover is ephemeral, though more persistent in the frigid areas.

The soils in this study include the mesic Gilpin and Laidig series, and the frigid Mandy, Snowdog, Gauley, and a tentative series that will be referred to as MWD Gauley. They are among the most extensive series in this region, within their respective temperature regimes. The classification of these series (Soil Survey Staff, 1994) as correlated in the soil surveys of the area prior to this study, and the number of sampled pedons of each are presented in Table 7.1. Table 7.1 presents the series as they occur in published soil surveys of the region, which span decades. Among these series, the Gilpin and Mandy, and the Laidig and Snowdog are essentially analogous pairs. Each pair occurs on the same types of landforms, from the same or similar geologic strata, under hardwood forest vegetation, and are of similar age. Differences in SOC stocks within these pairs are hypothesized to be largely a result of MAST. On the landforms where they are sampled, the major soil forming differences of significance in each pair are MAST and dominant forest species. 
Table 7.1. Correlated classification and number of pedons sampled of the soil series.

\begin{tabular}{llc} 
& & \# Pedons \\
$\frac{\text { Series }}{\text { Gilpin }}$ & $\frac{\text { Classification }}{\text { fine-loamy, mixed, mesic Typic Hapludults }}$ & \\
Laidig & fine-loamy, siliceous, mesic Aquic Fragiudults & 9 \\
Gauley & loamy-skeletal, siliceous, frigid Typic Haplorthods & 4 \\
MWD Gauley & loamy-skeletal, siliceous, frigid Aquic Haplorthods & 4 \\
Mandy & loamy-skeletal, mixed, frigid Typic Dystrochrepts & 4 \\
Snowdog & fine-loamy, mixed, frigid Aquic Fragiochrepts & 4 \\
\hline
\end{tabular}

The parent materials on these montane landscapes are acid sandstones and shales, with some coal layers (Price, 1968). The depth class, drainage, and typical landforms for each series are given in Table 7.2. Pedons from both north- and south-oriented aspects are represented to account for the varying effects on soil properties and biomass characteristics (Tajchman et al., 1996; Hicks and Frank, 1984). Other than the spodosols, all sampled pedons occur on at least $15 \%$ slope.

The region of this study covers much of the northeastern and southern units of WV forestland as delineated by DiGiovanni (1990). This region is over 80 percent forested, according to the National Resources Inventory of 1992 (SCS, 1994). The forests occurring on mesic sites are primarily oak-dominated central hardwoods and mixed mesophytic cove hardwoods. The mesic sites were not visited by the author. Data for these sites were acquired from the files of the USDA-NRCS. Therefore, the exact forest 
species composition and stand age are not known for the mesic sites. The vegetative characteristics of the frigid sites are covered in detail in Chapters 3 and 4.

Table 7.2. Depth, drainage, and typical landforms of the series.

\begin{tabular}{llll}
$\underline{\text { Series }}$ & $\underline{\text { Depth class }}$ & Drainage & Landform/parent material \\
Gilpin & $50-100 \mathrm{~cm}$ & well & Side-slopes, ridge-tops, residuum. \\
Laidig & $>2 \mathrm{~m}$ & mod. well & Side-slopes, foot-slopes, colluvium. \\
Mandy & $50-100 \mathrm{~cm}$ & well & Side-slopes, ridge-tops, residuum. \\
Snowdog & $>2 \mathrm{~m}$ & mod. well & Side-slopes, foot-slopes, colluvium. \\
Gauley & $50-100 \mathrm{~cm}$ & well & Ridge-tops, residuum. \\
MWD Gauley & $50-100 \mathrm{~cm}$ & mod. well & Ridge-tops, residuum. \\
\hline
\end{tabular}

\section{$\underline{\text { Sampling and Analyses }}$}

The frigid series were sampled in 1995 as part of an extensive frigid soil-sampling project, with SOC estimation as a major objective (Grossman, 1991). Details of this sampling are provided in Chapter 3.

The mesic series were sampled from 1977 to 1986 as part of USDA soil survey characterization plans, with standard protocols. The data used in this study for the mesic series were acquired from the USDA-NRCS National Soil Survey Laboratory, who publish their soil survey characterization data on the world wide web (http://vmhost.cdp.state.ne.us:96/METHD.HTML). In selection of the pedon data used 
for this work, only forested sites were chosen. In this database, O horizons had been described, but not sampled. For these horizons, organic carbon (OC) percentages and $\mathrm{Db}$ were estimated from the frigid hardwood site data. To estimate rock volume percentage of these $\mathrm{O}$ horizons, average values of the surface stone cover for the soil map units were utilized, usually about 10 to 15 percent. All mineral soil horizon Db determinations were made using the clod method (Blake and Hartge, 1986).

For the frigid series, we used a "frame" excavation method to obtain $\mathrm{Db}$ measurements of forest floor and epipedon horizons, developed by D. Harms and R.B. Grossman, NRCS, Lincoln, NE, for such situations. This method is detailed in Chapter 3, and in Grossman et al. (2001).

The frame- $\mathrm{Db}$ method was employed at 2 pedons of each frigid series. We reasoned that the detritus resulting from the differing forest types may lead to differences in $\mathrm{O}$ horizon bulk density. Therefore, the data were pooled into estimates of $\mathrm{Db}$ for the $\mathrm{O}$ horizons found under either hardwood (Mandy, Snowdog) or spruce (Gauley, MWD Gauley). We compared our values to those of Erich and Trusty (1997), Fernandez et al. (1993), and Huntington et al. (1989). All the above studies used an excavation technique, and Huntington et al. (1989) developed a regression of surface-horizon $\mathrm{Db}$ based on \%OC for stony forest soils $(\mathrm{r}=.72)$. If the frame-Db estimates developed in this study appeared reasonable in the context of the studies listed above, it was decided that we would utilize our pooled frame- $\mathrm{Db}$ estimates. We compared frame- $\mathrm{Db}$ estimates to the other studies, and plotted them against values obtained by using the regression of Huntington et al. 
(1989). Additionally, we evaluated $\mathrm{Db}$ estimates for A horizons by examining clod- $\mathrm{Db}$ and frame-Db data compared with regression estimates from Huntington et al. (1989) for A horizons occurring in the mesic study. Soil organic carbon estimates resulting from clod-Db-based calculations were then compared to frame-Db-based estimates for all epipedon horizons morphologically dominated by A characteristics (e.g. AB, but not BA) among the mesic series, and for all horizons for which we had frame-Db data among the frigid soil series. For this comparison, the SOC means were compared by series using ANOVA (Dowdy and Weardon, 1991). For all subsoil and substratum horizons (e.g. BA and below), the clod method was used (Blake and Hartge, 1986).

\section{Chemical Analyses and SOC Stocks}

All pedon samples were analyzed according to standard soil survey procedures (National Soil Survey Laboratory Staff, 1992), which are presented in further detail in Chapter 3. All SOC stocks were calculated to bedrock or Cr horizons, or $150 \mathrm{~cm}$, whichever was shallower. The average series SOC pools were then calculated. Analysis of variance (ANOVA) comparisons between clod and frame- $\mathrm{Db}$ methods, between analogous series, and between very deep and moderately deep series were then performed. The calculation for obtaining SOC stocks is as follows:

$$
\begin{aligned}
& \mathrm{SOCp}=\sum \mathrm{SOCh} \\
& \mathrm{SOCh}=\% \mathrm{C} / 100 \times \mathrm{Db} \times \mathrm{H} \times(1-\% \mathrm{RF} / 100) \times 1000 \mathrm{~kg} / \mathrm{Mg}
\end{aligned}
$$


Where: $\mathrm{SOCp}=$ Pedon SOC in $\mathrm{kg} \mathrm{m}^{-2} ; \mathrm{SOCh}=$ Horizon $\mathrm{SOC}$ in $\mathrm{kg} \mathrm{m}^{-2} ; \% \mathrm{C}=$ percent organic carbon of oven-dry soil $<2 \mathrm{~mm}$ fraction; $\mathrm{H}=$ horizon thickness in $\mathrm{m} ; \% \mathrm{RF}=$ volume percent rock fragments $>2 \mathrm{~mm}$.

\section{RESULTS AND DISCUSSION}

Using the frame-Db technique, we found a good correlation $\left(\mathrm{r}^{2}=.73\right)$ of our estimates to the regression method of Huntington et al. (1989) (Figure 7.1), although our values are generally lower than those of the referenced studies (Table 7.3). This was particularly true for Oi and Oe horizons, which occur in most forest soils of this region. The frame$\mathrm{Db}$ value for the AE horizon is notably lower than predicted by the regression, but the other values either correspond relatively closely or we have enough samples to accept the difference (e.g. Oi and Oe horizons). Conversely, we compared the $32 \mathrm{~A}, \mathrm{~A} / \mathrm{Oa}$, and AB horizons from the mesic series for which we had clod-Db values to the regression above. We found that the average measured clod $\mathrm{Db}$ is $1.03 \mathrm{Mg} \mathrm{m}^{-3}$, while the regression average is $0.49 \mathrm{Mg} \mathrm{m}^{-3}$, indicating the possibility of serious overestimation by the clod method for such horizons. The frame-Db measurements of A horizons among the frigid series averaged $0.36 \mathrm{Mg} \mathrm{m}^{-3}$, and regression estimates for those horizons was $0.46 \mathrm{Mg} \mathrm{m}^{-}$ ${ }^{3}$. Finally, we had clod-Db measurements for 5 A horizons among the frigid series. For those horizons, the average clod-Db was $1.14 \mathrm{Mg} \mathrm{m}^{-3}$, while the regression-Db was 0.57 $\mathrm{Mg} \mathrm{m}^{-3}$ for those horizons. Therefore we elected to utilize our pooled frame-Db values, after first comparing the resulting SOC estimates from both methods. The frame- and regression-based $\mathrm{Db}$ estimates for the frigid series are presented in Appendix F. 


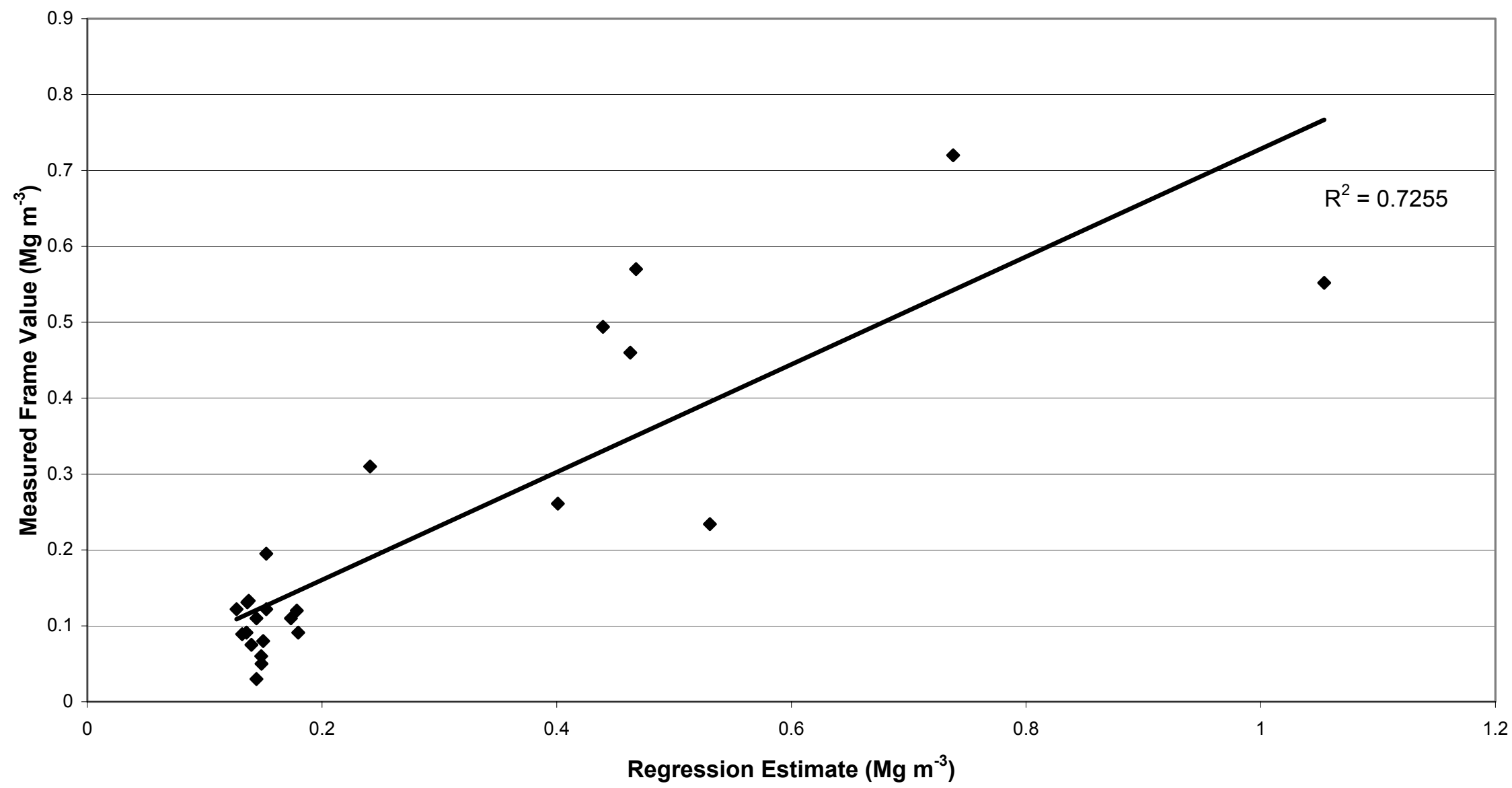

Figure 7.1. Frame vs. regression bulk density estimates for the series. 
Table 7.3. Comparison of frame bulk density values to other forest soil studies.

\begin{tabular}{|c|c|c|c|c|}
\hline Horizon & $\begin{array}{l}\text { Average } \\
\text { this study }\end{array}$ & $\begin{array}{l}\text { Huntington, } \\
\text { et al. } 1989^{\dagger}\end{array}$ & $\begin{array}{l}\text { Erich and Trusty, } \\
\underline{1997^{\ddagger}}\end{array}$ & $\begin{array}{l}\text { Fernandez et al., } \\
\underline{1993}\end{array}$ \\
\hline Oi & .07 & .15 & .145 & .13 \\
\hline $\mathrm{Oe}$ & .11 & .15 & -- & -- \\
\hline $\mathrm{Oa}$ & .26 & .20 & -- & -- \\
\hline A & .36 & .46 & -- & -- \\
\hline $\mathrm{AB}^{\S}$ & .72 & .74 & -- & -- \\
\hline $\mathrm{AE}^{\S}$ & .55 & 1.05 & -- & -- \\
\hline $\begin{array}{l}{ }^{\dagger} \text { From tl } \\
{ }^{\ddagger} \text { Combi } \\
\S \text { Single }\end{array}$ & $\begin{array}{l}\text { ession on } \\
\text { and Oe h } \\
\text { tes }\end{array}$ & $\begin{array}{l}\text { of this work } \\
\text { s. }\end{array}$ & & \\
\hline
\end{tabular}

The SOC estimates derived from clod-Db values are an average of $24 \%$ higher than those determined by using bulk density values based on our frame-Db work on the frigid series. The mean SOC estimates for each of these series are illustrated in Table 7.4. Given the likelihood that the clod-Db values for the horizons manipulated in this comparison overestimate whole-soil $\mathrm{Db}$, we suggest that the frame values yield results that are more realistic. The clod-Db approach yields significantly higher SOC values than does the frame-Db method $(\mathrm{p}<.01)($ Table 7.5$)$. 
Table 7.4. Soil organic carbon stock estimates for some major forest soils of West Virginia.

\section{Epipedon Db Method}

$\underline{\text { Mesic Series }}$

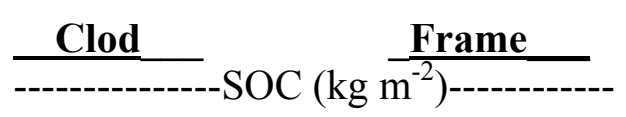

Gilpin

$11.8(4.1)^{\dagger}$

$8.9(3.2)$

Laidig

$14.5(3.5)$

$11.7(2.3)$

\section{$\underline{\text { Frigid Series }}$}

\begin{tabular}{llr} 
Mandy & $17.2(4.2)$ & $12.9(2.0)$ \\
Snowdog & -- & $18.8(1.7)$ \\
Gauley & -- & $11.3(3.0)$ \\
MWD Gauley & -- & $13.0(1.6)$ \\
\hline${ }^{\dagger}$ Standard deviation of the mean in parentheses.
\end{tabular}

All comparisons discussed from this point use frame- $\mathrm{Db}$ values. The frigid series contain significantly higher SOC stocks than their mesic analogs (Table 7.5), and the very deep series have higher SOC stocks than the moderately deep series. This effect of soil depth is interesting insofar as most SOC estimates are limited to $1 \mathrm{~m}$ (Eswaran et al., 1993, 1995; Kern 1994; Post et al., 1982, 1990). 
Table 7.5. Summary of statistical comparisons of soil organic carbon stocks.

Comparison

Clod $\mathrm{Db}>$ Frame $\mathrm{Db}$

Frigid vs. Mesic

Mandy $>$ Gilpin

Snowdog $>$ Laidig
$\underline{P}$

$<.01$

Very deep $>$ moderately deep $<.01$

The SOC stocks estimates for these series appear to fit well with other specifically studied forest soils in the frigid to thermic regions of the eastern US (Carter et al., 1997; Franzmeier et al., 1985; Huntington et al., 1989; Stone et al., 1993) as illustrated in Table 7.6. These SOC stock estimates fit fairly well within those proposed by SOC maps for this region where actual pedon data were used (Eswaran et al., 1993; Kern, 1994), but poorly compared to estimates generated from the Soil Interpretation Record database compiled by Bliss et al. (1995) (Table 7.7). 
Table 7.6. Soil Organic Carbon Stock Estimates for Central and Eastern US Soils.

$\underline{\text { Forested Soils }}$

Stone et al. 1993, Florida spodosols

Huntington et al. 1989, New Hampshire spodosols

This study:

Frigid spodosols, inceptisols

Mesic ultisols

$\underline{\text { Agricultural Soils }}$

Franzmeir et al. 1985, central US udalfs and ochrepts

Carter et al. 1997, eastern Canada
$\underline{\operatorname{SOC}\left(\mathrm{kg} \mathrm{m}^{-2}\right)}$

4.9-12.6

16

$11.3-18.8$

8.9-11.7

$6.0-7.3$

$3-16$ 
Table 7.7 . A Review of Soil Organic Stock Estimates for the Allegheny Plateau

Region of West Virginia.

Source $\quad \underline{\mathrm{SOC}\left(\mathrm{kg} \mathrm{m}^{-2}\right)}$

Kern (1994)

1. Ecosystem approach 28.1-32.0

2. Soil taxonomy 13.6-15.0

Eswaran et al. (1993)

World Soils Map 10.6-12.1

Bliss et al. (1995)

Soil Interpretation Database

2.2

This study

1. Mesic series

2. Frigid hardwood sites.

$12.9-18.8$

3. Frigid spruce sites.

$11.3-13.0$

\section{CONCLUSIONS}

We have determined the SOC stocks of six major forest soils occurring on the Allegheny

Plateau of West Virginia. Previous works have illustrated regional and continental associations of temperature and SOC sequestration. However, in this study only minimal changes in other soil forming factors accompany the change in mean annual soil temperature. Due to differences in elevation, we were able to compare adjacent forested 
mesic and frigid series. We found that the frigid series have significantly higher SOC stocks than their respective mesic analogues.

The estimates developed are significantly affected by the type of bulk density methods that are applied. In the surface horizons of this region, the high amounts of rocks, roots, and organic matter render core and clod sampling either impractical or unrepresentative. The use of the frame method of excavation shows great promise. The correlation of our frame values with the work of others (e.g. Huntington et al., 1989) indicates that using frame $\mathrm{Db}$ values provided satisfactorily accurate estimates of $\mathrm{Db}$ for forest soil nearsurface horizons. There is compelling reason to think that $\mathrm{Clod}-\mathrm{Db}$ values for forest soil A horizons result in significant overestimation (24\%) of SOC estimates. Nonetheless, the frame-Db data used in this study lack the power of having a larger sample size, and representative $\mathrm{Db}$ data are sorely needed for forest floor and mineral surface horizons of this region. The inclusion of $\mathrm{O}$ horizons is an important aspect of SOC estimation for the forest soils of this region. Most SOC stock estimates of the series in this study include about $1 \mathrm{~kg} \mathrm{~m}^{-2}$ or more SOC from Oi and Oe horizons alone.

The estimates of SOC presented here are for some of the most extensive soil series in this region. Given that the most extensive soils in this region are mesic, then both the SOC estimates for WV used in the World Soils Map (Eswaran et al., 1993) and taxonomic approaches as applied by Kern (1994) seem reasonable. However, improvement of Db techniques to account for clod based error in surface horizons would significantly alter those SOC estimates. It would appear that the use of clod-Db data, and the lack of O 
horizon data that determine the SOC estimates of the models counteract one another to some degree. The SIR approach (Bliss et al., 1995) results in an apparently gross underestimate, and brings into question the utility of SIR's for such work. As the USDA transitions from SIR-based interpretations to those based on the National Soil Information System (NASIS), care should be taken to focus on SOC estimation methods and data.

\section{REFERENCES}

Arnold, R.W. 1995. The role of soil survey in obtaining a global carbon budget. p. 257263. In R. Lal et al. (ed.) Soils and global change. CRC Press, Boca Raton, FL.

Blake, G.R., and K.H. Hartge. 1986. Bulk density. p. 363-375. In A. Klute (ed.)

methods of soil analysis. Part 1. $2^{\text {nd }}$ ed Agron. Monogr. 9. ASA and SSSA, Madison, WI.

Bliss, N.B., S.W. Waltman, and G.W. Peterson. 1995. Preparing a soil carbon inventory for the United States using geographic information systems. p. 275 -295. In R. Lal et al. (ed.) Soils and global change. CRC Press, Boca Raton, FL.

Carter, B.J., and E.J. Ciolkosz. 1980. Soil temperature regimes of the central Appalachians. Soil Sci. Soc. Am. J. 44: 1052-1058. 
Carter, M.R., D.A. Angers, E.G. Gregorich, and M.A. Bolinder. 1997. Organic carbon and nitrogen stocks and storage profiles in cool, humid soils of eastern Canada. Can. J. Soil Sci. 77:205-210.

Curtis, R.O., and B.W. Post. 1964. Estimating bulk density from organic matter content in some Vermont forest soils. Soil Sci. Soc. Am. Proc. 28(2): 285-286.

DiGiovanni, D.M. 1990. Forest Statistics of West Virginia -- 1975 and 1989. NE Forest Experiment Station, Broomall, Pennsylvania.

Dowdy, S. and S. Weardon. 1991. Statistics for Research. John Wiley and Sons, Inc., New York, NY.

Erich, S.E., and G.M. Trusty. 1997. Chemical characterization of dissolved organic matter released by limed and unlimed forest soil horizons. Can J. Soil Sci. 77:4045-413.

Eswaran, H., E. VanDen Berg, and P. Reich. 1993. Organic carbon in soils of the world. Soil Sci. Soc. Am. J. 57:192-194.

Eswaran, H., I. Van den Berg, P.Reich, and J. Kimble. 1995. Global soil carbon resources. p. 27-43. In R. Lal et al. (ed.) Soils and global change. CRC Press, Boca Raton, FL. 
Fernandez, I.J., L.E. Rustad, and G.B. Lawrence. 1993. Estimating total soil mass, nutrient content, and trace metals in soils under a low elevation spruce-fir forest. Can. J. Soil Sci. 73: 317-328.

Franzmeier, D.P., G.D. Lemme, and R.J. Miles. 1985. Organic carbon in soils of North Central United States. Soil Sci. Soc. Am. J. 49:702-708.

Grossman, R.B. 1991. Work group 1: Organic matter. p. 72-77. In Waltman et al. (ed) Proceedings of the first soil genesis modeling conference 13-15 Aug. 1991. USDANatural Resources Conservation Service, National Soil Survey Center, Lincoln, NE

Grossman, R.B, D.S. Harms, D.F. Kingsbury, R.K. Shaw, and A.B. Jenkins. 2001. Assessment of soil organic carbon using the U.S. soil survey. p. 87 - 104. In Lal et al. (eds.) Assessment Methods for Soil Carbon. Lewis Publishers, Boca Raton, Florida.

Hicks, R.R.Jr., and P.S. Frank. 1984. Relationship of aspect to soil nutrients, species importance, and biomass in a forested watershed in West Virginia. For. Ecol. and Mngt. 8:281-291.

Homann, P.S., P. Sollins, H.N. Chappell, and A.G. Stangenberger. 1995. Soil organic carbon in a mountainous, forested region: relation to site characteristics. Soil Sci. Soc. Am. J. 59:1468-1475. 
Huntington, T.G., C.E. Johnson, A.H. Johnson, T.G. Siccama, and D.F. Ryan. 1989. Carbon, organic mater, and bulk density relationships in a forested spodosol. Soil Sci. 148(5):380-386.

Jenny, H. 1980. The Soil Resource. Springer-Verlag, New York.

Kern, J.S. 1994. Spatial patterns of soil organic carbon distribution in the contiguous United States. Soil Sci. Soc. Am. J. 58: 439-455.

Lal, R., J. Kimble, E. Levine, and C. Whitman. 1995. World soils and greenhouse effect: An overview. p. 1-7. In R. Lal et al. (ed.) Soils and global change. CRC Press, Boca Raton, FL.

Manrique, L.A., and C.A. Jones. 1991. Bulk density of soils in relation to soil physical and chemical properties. Soil Sci. Soc. Am. J. 55: 476-481.

Post, W.M., W.R. Emanuel, P.J. Zinke, and A.G. Stangenberger. 1982. Soil carbon pools and world life zones. Nature 298:156-159.

Post, W.M., T.H. Peng, W.R. Emanuel, A.W. King, V.H. Dale, and D.L. De Angelis. 1990. The global carbon cycle. Am. Sci. 78:310-326.

Price, P.H. 1968. Geologic map of West Virginia. WV Geologic and Economic Survey. 
Snyder, K.E., and S.A.L. Pilgrim. 1985. Sharper focus on forest floor horizons. Soil Surv. Horizons 26(3):9-15.

Soil Conservation Service. 1994. Summary report: 1992 National Resources Inventory. USDA Natural Resources Conservation Service. Washington, DC.

Soil Survey Laboratory Staff. 1992. Soil survey laboratory methods manual. Soil Surv. Invest. Rep. 42. Version 2.0 USDA-SCS U.S. Gov. Print Office, Washington, DC.

Soil Survey Staff. 1994. Keys to Soil Taxonomy, $6^{\text {th }}$ edition, USDA-Soil Conservation Service, Pocahontas Press, Blacksburg, VA.

Stone, E.L., Harris, W.G., Brown, R.B., and Kuehl, R.J. 1993. Carbon storage in Florida Spodosols. Soil Sci. Soc. Am. J. 57:179-182.

Tajchman, S.J., R. Benyon, L. Bren, J. Kochenderfer, and C. Pan. 1996. On spatial variability of above-ground biomass. Biomass and Bioenergy 11(5):383-386.

USDA. 1981. Major Land Resource Areas of the United States. US Department of Agriculture, Soil Conservation Service. Agricultural Handbook 296. Washington, D.C.

Vincent, K.R., and O.A. Chadwick. 1994. Synthesizing bulk density for soils with abundant rock fragments. Soil Sci. Soc. Am. J. 58:455-464. 


\section{CHAPTER EIGHT}

\section{CALCIUM AND MAGNESIUM IN HIGH ELEVATION FOREST SOILS OF WEST VIRGINIA}

\section{INTRODUCTION}

The productivity of some forest ecosystems in eastern North America may be limited by Ca and Mg availability and Al toxicity in soils (Ellsworth and Liu, 1994; Wilmot et al., 1995, 1996; Millers et al., 1991; Hendershot and Courchesne, 1994; Hendershot and Jones, 1989; Shortle and Smith, 1988). The most commonly hypothesized mechanisms of forest $\mathrm{Ca}$ and $\mathrm{Mg}$ deficiency are associated with soil acidification. Sharpe and Sunderland (1995) found that soils supporting declining sugar maple stands in Pennsylvania had lower $\mathrm{pH}$ and base saturation than those of similar but non-declining stands. Increases in Al activity likely compound productivity threats posed by soil nutrient deficiencies. The mechanisms of decline are unclear, but high Al concentrations are noted in declining northeastern spruce stands and are commonly thought to inhibit Ca uptake and transport (Shortle and Smith, 1988). Calcium and Mg concentrations in root tips of declining red spruce at five locations were inversely related to soil solution $\left[\mathrm{Al}^{3+}\right]$. The ratio of $\mathrm{Ca}: \mathrm{Al}$ was lower in Oa than Oe horizons, and was found to decline in roots as site elevation increased (Shortle et al., 1995). Minocha et al. (1997) and Shortle et al. (1997) studied red spruce stands at sites across the northeastern U.S. and found that lower soil solution $\mathrm{Ca}$ :Al ratios were significantly correlated with increases in the foliar concentration of dendrochemical stress markers putrescine and spermidine. Furthermore, Minocha et al. 
(1997) found that $\mathrm{Ca}$ and $\mathrm{Mg}$ concentrations in the needles of healthy trees were strongly correlated to extractable soil concentrations of those elements.

Cronan and Grigal (1995) studied soil solution $\mathrm{Ca}$ and $\mathrm{Al}$ and proposed molar $\mathrm{Ca}$ to $\mathrm{Al}$ ratios that are indicative of potential forest decline or productivity loss, particularly where the base saturation of effective cation exchange capacity (BSECEC) is low. Scientists in Europe used the ratio of the sum of base cations to $\mathrm{Al}$ to indicate potential productivity problems, and this method has been applied in Maryland, USA (Sverdrup et al., 1995). Soil acidification and fertility reductions have been documented in forest soils of the eastern United States. Drohan and Sharpe (1997) report that forest floor and upper horizons of major Pennsylvania forest soils are acidifying, with associated increases in extractable $\mathrm{Al}$ and decreases in extractable $\mathrm{Mg}$ and in some cases $\mathrm{Ca}$. They further note that foliar Mg concentrations in red oak and red maple appear low in many locations across the region of their study. MacDonald et al. (1992) demonstrated increasing cation leaching across a regional acid deposition gradient. Davis et al. (1995) sampled red maple, red oak, and white oak along a gradient of increasing $\mathrm{H}^{+}$and $\mathrm{SO}_{4}{ }^{-2}$ deposition in Pennsylvania. They observed significantly lower foliar $\mathrm{Ca}$ in oaks receiving higher deposition.

The amounts of $\mathrm{Ca}$ and $\mathrm{Mg}$ in some eastern forest ecosystems has received attention with regard to forest harvest impacts and leaching losses (Adams et al., 1999). Federer et al. (1989) and Mann et al. (1988) compiled total soil Ca and Mg estimates from northern hardwood-, spruce-, and oak-dominated sites from Maine to Tennessee. Total soil Ca 
ranged from 3.4 to over $10 \mathrm{Mg} \mathrm{ha}^{-1}$, and total $\mathrm{Mg}$ ranged from 6.3 to over $36 \mathrm{Mg} \mathrm{ha}^{-1}$. Although the studies compiled by Federer et al. (1989) and Mann et al. (1988) varied in the depth to which nutrient pools were estimated (from about .5 to $1 \mathrm{~m}$ ), it was hypothesized that the volume of major root activity was evaluated. They noted that some forests could face $\mathrm{Ca}$ deficiencies within as little as three harvest rotations. To date, documentation of harvest-induced Ca deficiency is largely anecdotal (Likens and Bormann, 1996). Nonetheless, past harvest removals must have some relationship to contemporary soil $\mathrm{Ca}$ and $\mathrm{Mg}$ content. Federer et al. (1989) found Ca leaching to occur at a rate of 10 to $22 \mathrm{~kg} \mathrm{ha}^{-1} \mathrm{yr}^{-1}$ across the northeast, which can more than double following intensive forest harvesting. Inputs of $\mathrm{Ca}$ and $\mathrm{Mg}$ averaged less than $5 \mathrm{~kg} \mathrm{ha}^{-1} \mathrm{yr}^{-1}$, and are currently declining across the region (Hedin et al., 1994). Although weathering inputs of base cations are highly variable and difficult to quantify, Sr isotope studies for northeastern forest soil ecosystems have indicated that much of the $\mathrm{Ca}$ in vegetation is from atmospheric deposition, and that negative $\mathrm{Ca}$ input-output relationships are common throughout the region (Bailey et al., 1996).

The forests on the Allegheny Plateau of West Virginia receive among the most intense loadings of acid deposition in the U.S., which increase significantly with elevation (Gilliam and Adams, 1996). Loading rates of $\mathrm{N}$ range from 15 to $20 \mathrm{~kg} \mathrm{ha}^{-1} \mathrm{yr}^{-1}$ across West Virginia (Adams et al., 1995; Gilliam and Adams, 1996; Hicks et al., 1992), where many watersheds are already N saturated (Adams et al., 1997) and exhibit negative acid neutralization capacities in streamwater (Webb et al., 1997). The annual leaching of Ca from undisturbed, lower-elevation watersheds in this region averages about $14 \mathrm{~kg} \mathrm{ha}^{-1}$ 
(Adams et al., 1995; Hicks et al., 1992), more than twice the rate of deposition. Nutrient cation leaching may be expected to increase across the region, if increases in $\mathrm{N}$ deposition occur as predicted (Aber et al., 1993).

In this study, our objectives were to determine extractable and total pools of $\mathrm{Ca}$ and $\mathrm{Mg}$ for the most extensive frigid soil series in West Virginia; to compare these data to published data from other sites; and to examine the relationships of $\mathrm{Ca}$ and $\mathrm{Mg}$, soil Ca:Al ratios, and BSECEC to soil organic carbon (SOC) and soil depth.

\section{MATERIALS AND METHODS}

\section{$\underline{\text { Study Area and Soil Series }}$}

The study area was located in the Monongahela National Forest, in Major Land Resource Area 127 (USDA, 1981) on the Allegheny Plateau of West Virginia, USA. The study area, soils, and sampling methodology are described in detail in the preceding Chapters. Additional information is presented in this Chapter wherever relevant, or where changes from previously described procedures have been made.

Four pedons of the each of the major frigid series were sampled. Only three pedons of the MWD Gauley were used in comparisons of this study because some samples were contaminated with calcareous dust and drainage from a nearby gravel road. The tentative Blackwater series was omitted from this work due to its small sample size and unknown extent. 


\section{Sampling and Analyses}

\section{Bulk Density}

For the calculation of nutrient stocks, it was decided that the recent litter layers (Oi1 horizons) should be included to the extent possible. Therefore, the undecomposed leaf litter layer was given an arbitrary $\mathrm{Db}$ of $0.05 \mathrm{Mg} \mathrm{m}^{-3}$. Additional $\mathrm{Db}$ values are given in Appendix B, and were developed as outlined in Chapter 7.

\section{Chemical Analyses and Nutrient Pools}

Chemical and physical properties of each pedon were characterized by horizon, with all samples analyzed according to standard soil survey procedures (National Soil Survey Laboratory Staff, 1996), with the exception of total elemental analyses, which are described in Chapter 3. All nutrient stocks were calculated by horizon to a depth of 150 $\mathrm{cm}$ or to bedrock, whichever was shallower. We used a one-way analysis of variance (ANOVA) to test for significant differences in $\mathrm{Ca}$ and $\mathrm{Mg}$ content among the series, and then used Least Significant Difference (LSD) to compare adjacent means with a prior significant F value (Dowdy and Weardon, 1991).

Extractable and total $\mathrm{Ca}$ and $\mathrm{Mg}$ were plotted against soil depth and SOC to look for relationships of these nutrients in the context of mineral and organic nutrient reserves. In order to fit lines and obtain correlation coefficients for extractable $\mathrm{Ca}$ and $\mathrm{Mg}$ 
distributions, it was necessary to replace zero concentration values with an arbitrary 0.01 $\mathrm{mg} \mathrm{kg}^{-1}$.

\section{RESULTS AND DISCUSSION}

\section{Amounts and Distribution of Ca and Mg}

Total Ca in these soils ranged from 497 to $1095 \mathrm{~kg} \mathrm{ha}^{-1}$, and total Mg ranged from 2085 to $6662 \mathrm{~kg} \mathrm{ha}^{-1}$ (Table 8.1). The total soil reserves of these elements are much smaller than those of similar forest ecosystems summarized by Mann et al. (1988) and Federer et al. (1989). The average total stocks of $\mathrm{Ca}$ from their studies range from 4 to more than 20 times greater than those of this study. However, it should be noted that the methods of total elemental analysis may not be compatible. The highest total Mg stocks of this study were about equivalent to the lowest $\mathrm{Mg}$ values found in the studies cited above.

Restricting nutrient stock calculations to a depth of $1 \mathrm{~m}$, a maximum depth in the abovereferenced studies, would further reduce the total stocks of $\mathrm{Ca}$ and $\mathrm{Mg}$ by 32 to 36 percent for the very deep Snowdog series.

The amount of extractable $\mathrm{Ca}$ in these series (Table 8.1) is similar to data reported for northern hardwood and oak sites in New Hampshire $\left(370 \mathrm{~kg} \mathrm{ha}^{-1}\right)$ and Tennessee (270

$\mathrm{kg} \mathrm{ha}^{-1}$ ) (Johnson et al., 1991; D.W. Johnson and Todd, 1987). However, in New Hampshire and Tennessee those values represented only 3 and 7 percent of the total soil Ca stocks, respectively, while extractable $\mathrm{Ca}$ was approximately $30 \%$ of the total $\mathrm{Ca}$ in our study. Clearly, the extractable stocks of $\mathrm{Ca}$ do not reflect the magnitude of the total 
Ca reserves among different sites across the eastern United States. Nonetheless, the ratio of extractable to total base cation pools may be a very useful relative value of soils' buffering capacity against nutrient depletion. For these series, the total Ca pools are much lower than the total $\mathrm{Mg}$ pools, yet the extractable Ca pools are 2 to 3 times greater than for $\mathrm{Mg}$ (Table 8.1). These relationships may indicate that geochemical Ca reserves are relatively low and more easily extractable than Mg pools. 


\section{Table 8.1. Extractable and total calcium and magnesium for the series}

\begin{tabular}{|c|c|c|c|c|c|c|}
\hline$\underline{\text { Soil Series }}$ & Extr. Ca & $\underline{\text { Total Ca }}$ & Exch./Tot. Ca & Exch. Mg & $\underline{\text { Total } \mathrm{Mg}}$ & Exch./Tot. Mg \\
\hline \multirow[b]{2}{*}{ Mandy } & \multicolumn{3}{|c|}{--------kg ha ${ }^{-1}$} & \multicolumn{3}{|c|}{----------kg ha ${ }^{-1}$----------' } \\
\hline & $192(.51)^{\dagger} \mathrm{a}^{\ddagger}$ & $513(.35) \mathrm{a}$ & .37 & $51(.46) \mathrm{a}$ & $3896(.29) \mathrm{a}$ & .013 \\
\hline Snowdog & $350(.44) \mathrm{a}$ & $1095(.40) \mathrm{b}$ & .32 & $126(.29) \mathrm{b}$ & $6662(.43) b$ & .019 \\
\hline Gauley & $162(.63) \mathrm{a}$ & $497(.38) \mathrm{a}$ & .33 & $28(.67) \mathrm{a}$ & $2085(.45) \mathrm{a}$ & .013 \\
\hline WD Gauley & $173(.19) \mathrm{a}$ & $650(.80) \mathrm{a}$ & .24 & $66(.09) \mathrm{a}$ & $2304(.85) \mathrm{a}$ & .029 \\
\hline
\end{tabular}


Snowdog has significantly greater $(\mathrm{P}<0.05)$ amounts of total $\mathrm{Ca}$ and extractable and total $\mathrm{Mg}$ than do the other series. When we restricted the depth of nutrient pool calculation to $1 \mathrm{~m}$ for Snowdog and compared these values to those of the other series, significant differences were observed only for extractable and total Mg (Snowdog > Gauley and MWD Gauley, data not shown). No other differences were statistically significant among the series.

In view of the relatively low nutrient reserves of these series, the distribution of $\mathrm{Ca}$ and $\mathrm{Mg}$ in mineral and organic reservoirs warrants examination. By examining the distribution of these nutrients as they relate to SOC and soil depth, inferences can be made as to the sources of fertility for these series. For a typical soil profile among these series, the lower soil horizons are described as being less weathered materials, often transitional to the parent geology. As SOM and CEC declined with depth in these profiles, we expected to see declining extractable $\mathrm{Ca}$ and $\mathrm{Mg}$. However, in the lower subsoil and substratum (B and C) horizons, we expected to see significant or increasing total $\mathrm{Ca}$ and $\mathrm{Mg}$ due to the less-weathered nature of these horizons. Soil organic carbon concentrations do indeed decrease exponentially with soil depth (Figure 5.1), as does CEC (not shown). Extractable and total $\mathrm{Ca}$, and extractable $\mathrm{Mg}$, were correlated with SOC (Figures 8.1 and 8.2), but total Mg was poorly correlated with SOC (Figure 8.2). 


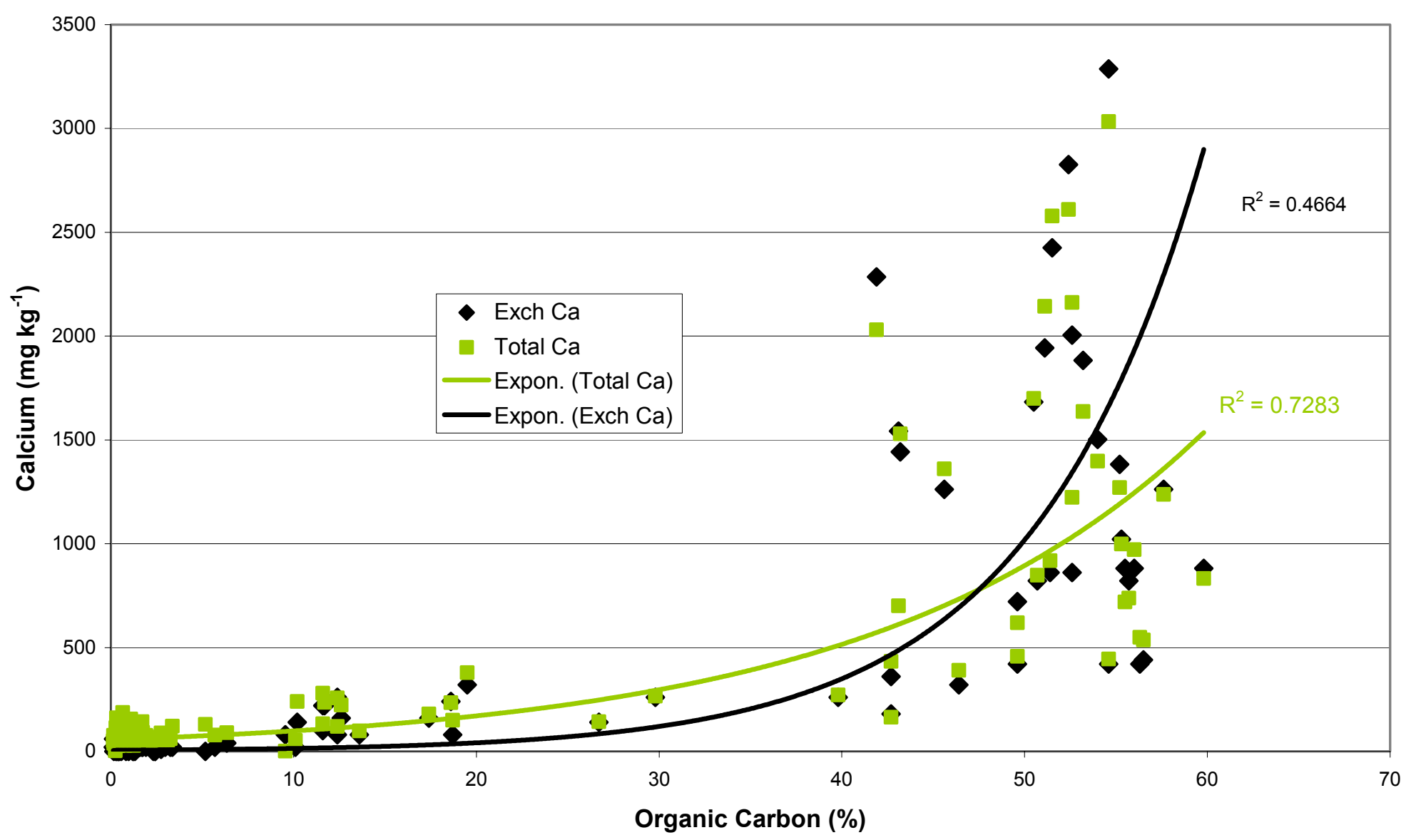

Figure 8.1. Relationship of extractable and total calcium to soil organic carbon for the series. 


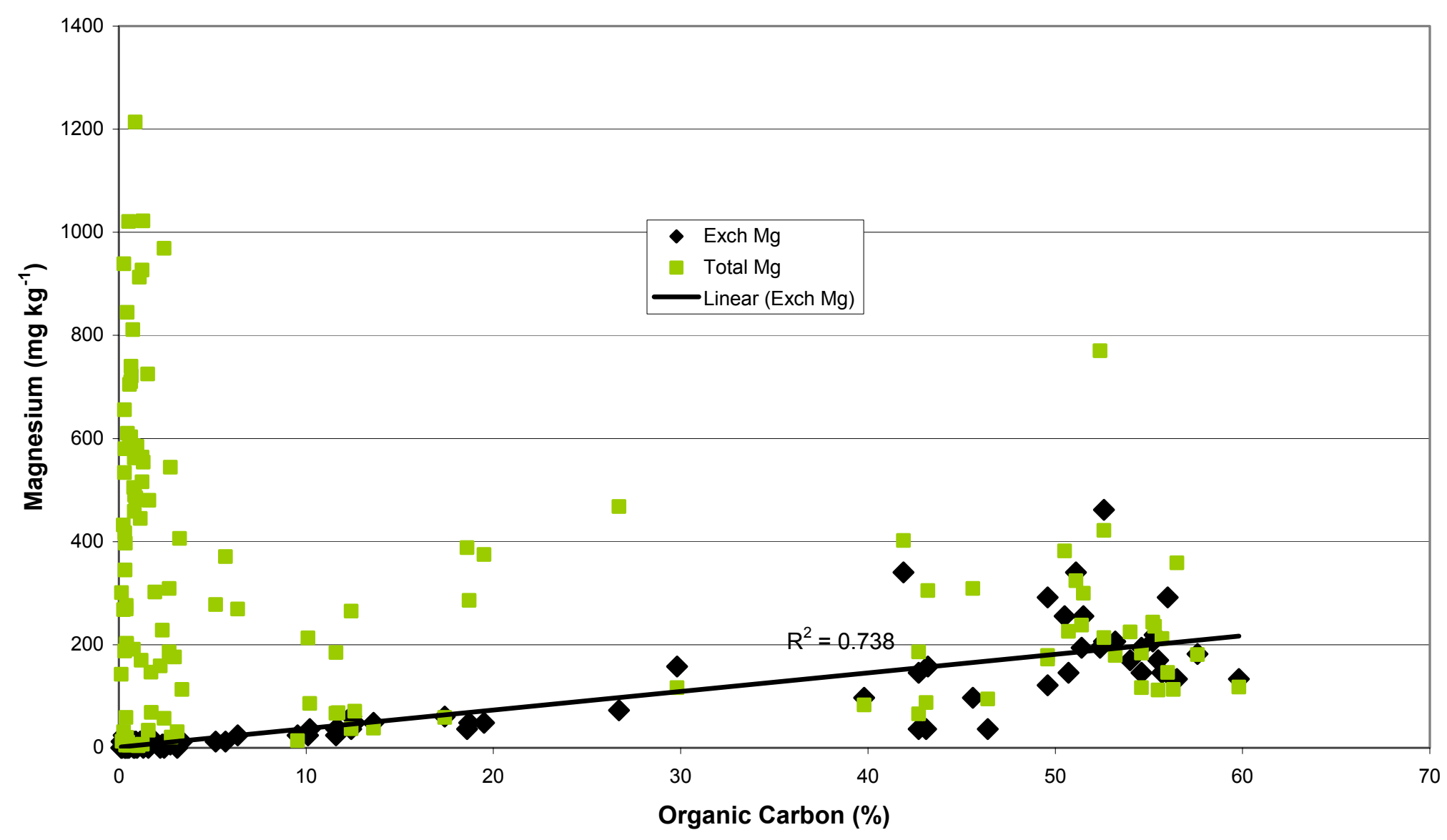

Figure 8.2. Relationship of extractable and total magnesium to soil organic carbon for the series. 
The distribution of total $\mathrm{Ca}$, as well as extractable $\mathrm{Ca}$ and $\mathrm{Mg}$ (Figures 8.3 and 8.4), with increasing soil depth is virtually identical to that of SOC (Figure 5.1). The concentrations of these nutrient pools decline exponentially with depth, and do not recover in the substrata. This was expected of the extractable nutrients, but the distributions of extractable and total $\mathrm{Ca}$ concentrations are very similar. Extractable Ca concentrations explain more than $98 \%$ of the total Ca variation (Figure 8.5). This contradicts our expectation that total pools of $\mathrm{Ca}$ would be considerably greater in the less weathered matrices of deeper soil horizons. Although extractable and total concentrations of $\mathrm{Mg}$ are similar in the upper $20 \mathrm{~cm}$ of the soils (Figure 10), they rapidly diverge with depth. Total $\mathrm{Mg}$ concentrations generally peaked in the pedon substrata. Where $\mathrm{E}$ horizons were expressed sufficiently for sampling (Gauley, MWD Gauley), minimum pedon values of both extractable and total Mg were observed. 


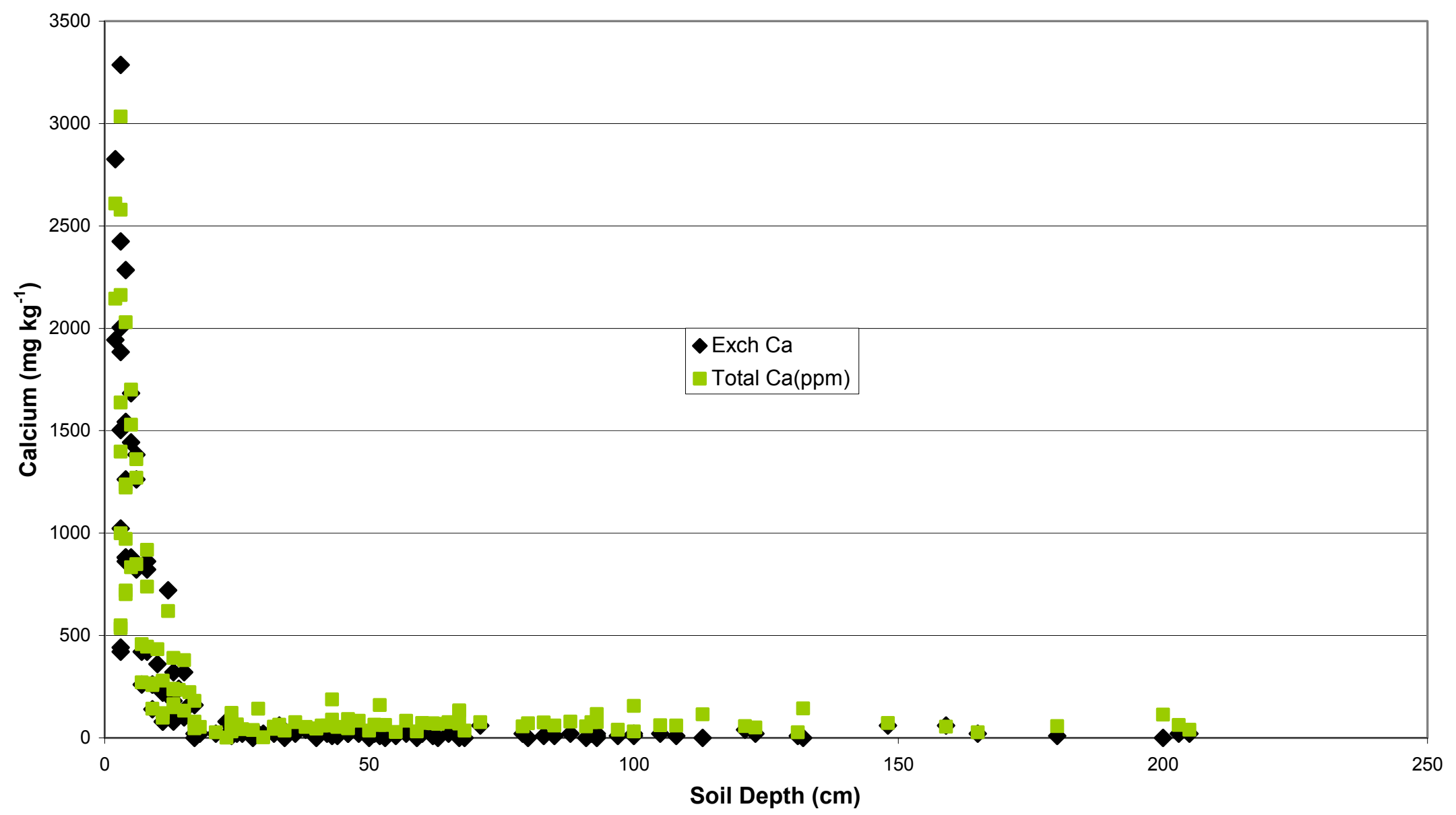

Figure 8.3. Relationship of extractable and total calcium to soil depth for the series. 


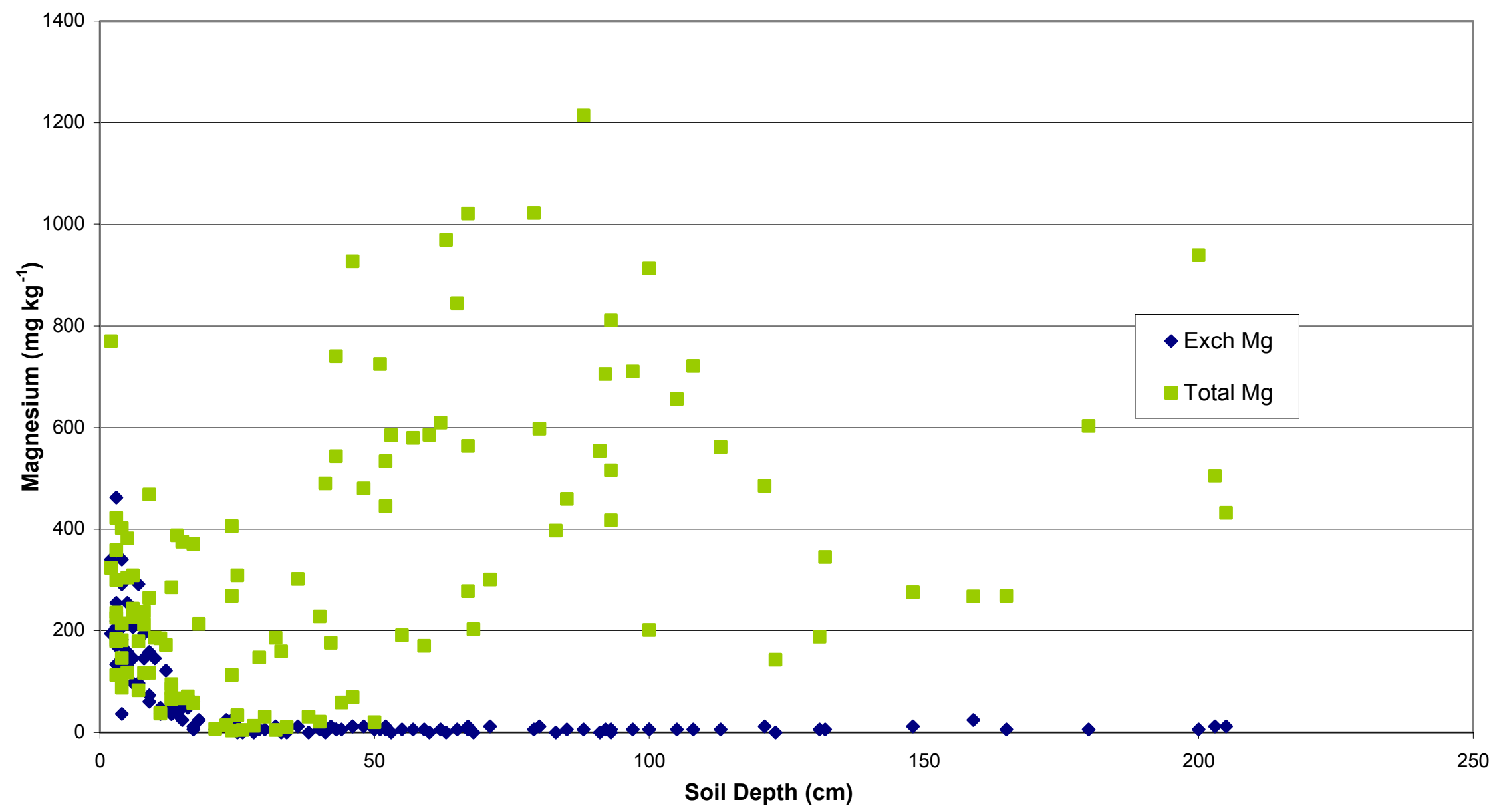

Figure 8.4. Relationship of extractable and total magnesium to soil depth for the series. 


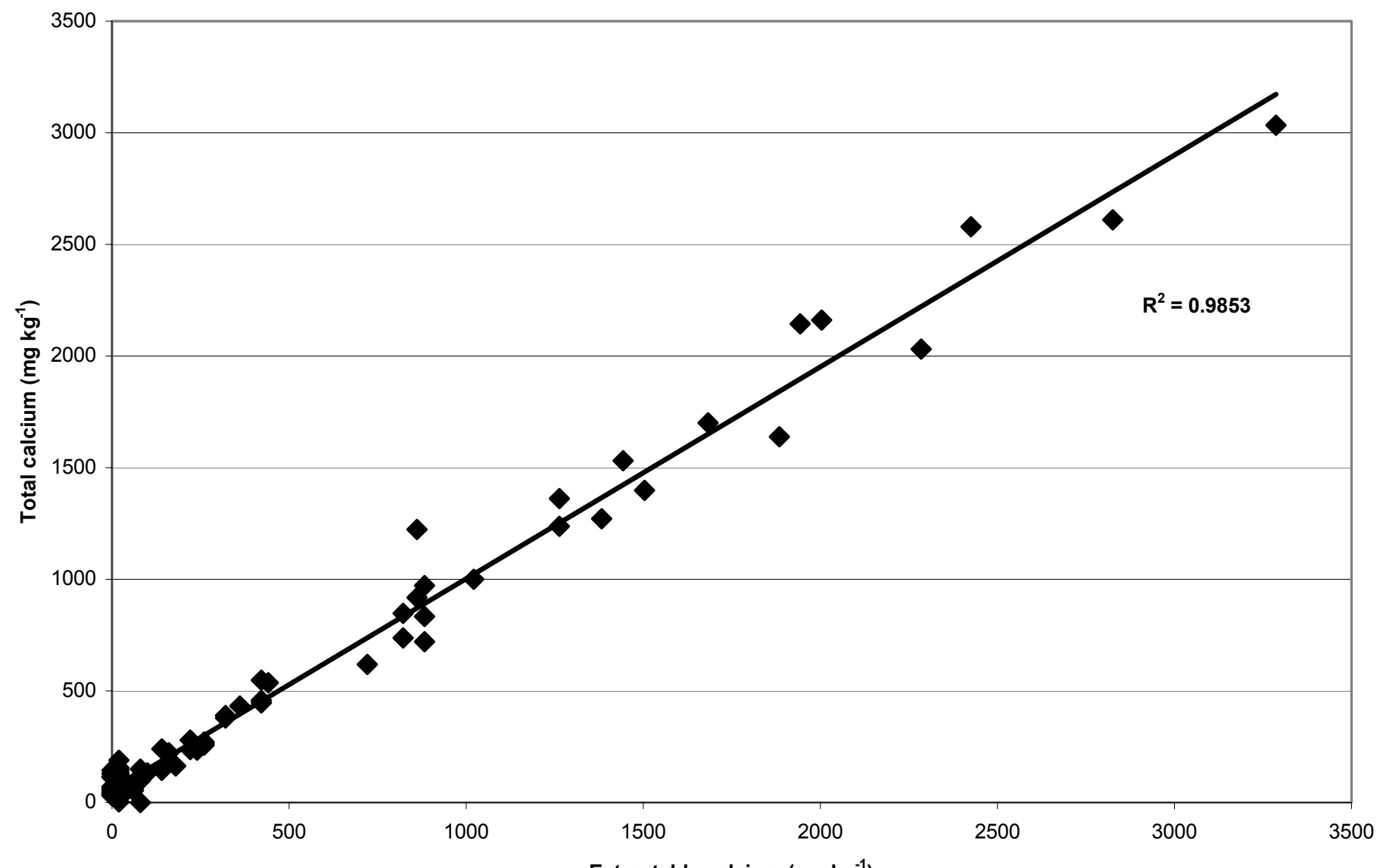

Figure 8.5. Relationsktractable calciym $\left.{ }^{\left(\mathrm{mg}_{\mathrm{kg}} \mathrm{kg}^{-1}\right.}\right)$ calcium for the series 
Generally, the relationships outlined above were even more clearly exhibited in the case of individual series (Table 8.2). The MWD Gauley was the most variable among the series, perhaps because of fewer samples and the influence of a seasonal high water table, which may serve to laterally redistribute nutrients above the bedrock. Interestingly, total Mg was poorly correlated to soil depth for the Snowdog series, which we attribute to the effects of mixing associated with the colluvial genesis of this soil. 
Table 8.2. Relationship ${ }^{\dagger}$ of calcium and magnesium concentrations to soil organic carbon and depth for the series.

\begin{tabular}{|c|c|c|c|c|c|c|c|c|}
\hline \multirow[b]{4}{*}{ Gauley } & \multicolumn{4}{|c|}{ Calcium } & \multicolumn{4}{|c|}{ Magnesium } \\
\hline & \multicolumn{2}{|c|}{$\mathrm{x} \mathrm{SOC}$} & \multicolumn{2}{|c|}{ x Depth } & \multicolumn{2}{|c|}{$\mathrm{x} \mathrm{SOC}$} & \multicolumn{2}{|c|}{ x Depth } \\
\hline & Extr. & Total & Extr. & Total & Extr. & Total & Extr. & Total \\
\hline & $\overline{0.91}$ & $\overline{0.94}$ & $-\overline{0.66}$ & $-\overline{0.79}$ & $\overline{0.93}$ & $-{ }^{+}$ & $-\overline{-0.66}$ & 0.59 \\
\hline MWD Gauley & 0.83 & 0.77 & -0.76 & -0.58 & 0.89 & -- & -0.78 & 0.60 \\
\hline Mandy & 0.93 & 0.96 & -0.87 & -0.90 & 0.85 & -- & -0.75 & 0.72 \\
\hline Snowdog & 0.79 & 0.94 & -0.79 & -0.85 & 0.86 & -- & -0.89 & 0.27 \\
\hline
\end{tabular}

$\dagger$ Values are linear or exponential equation regression coefficients (r).

No correlation was observed for this comparison. 


\section{$\underline{\text { Aluminum and Acidity Considerations }}$}

The BSECEC and the Ca:Al ratio drop below 15 percent and 0.2, respectively, within 20 $\mathrm{cm}$ in most pedons in our study (Figures 8.6 and 8.7). The Ca:Al ratio and BSECEC are important indicators of potential forest productivity decline. Cronan and Grigal (1995) reported that nearly 100 percent risk of forest productivity loss exists at values of soil solution Ca:Al ratios of 0.2 or less, particularly when BSECEC values are less than 15 percent. Although we have no soil solution data, David and Lawrence (1996) found that as much as 75 percent of soil solution Ca:Al variability was explained by extractable values in the Oa horizons of forested spodosols in New England. In most pedons of this study, the depths where acidity parameters become potentially limiting generally correspond to SOC values decreasing from the organic into the mineral soil. These phenomena are likely a function of acidity buffering by organic matter, in addition to the biological enrichment of the upper horizons with base cations (Henderson, 1995; Joslin and Wolfe, 1989; Wolt, 1994). Both the BSECEC and Ca:Al values are correlated to SOC percentage for these series $\left(\mathrm{R}^{2}=0.88\right.$ and 0.73 , respectively). Based on the very low BSECEC and thus, the high degree of Al saturation, it appears that these series have very little buffering capacity against $\mathrm{Ca}$ and $\mathrm{Mg}$ leaching or increasing $\mathrm{Al}$ activity other than that afforded by soil organic matter. Furthermore, below the epipedons, the inhospitable environment for roots may reduce the likelihood that mobilized nutrient cations will be biologically intercepted, thus compounding leaching losses. 


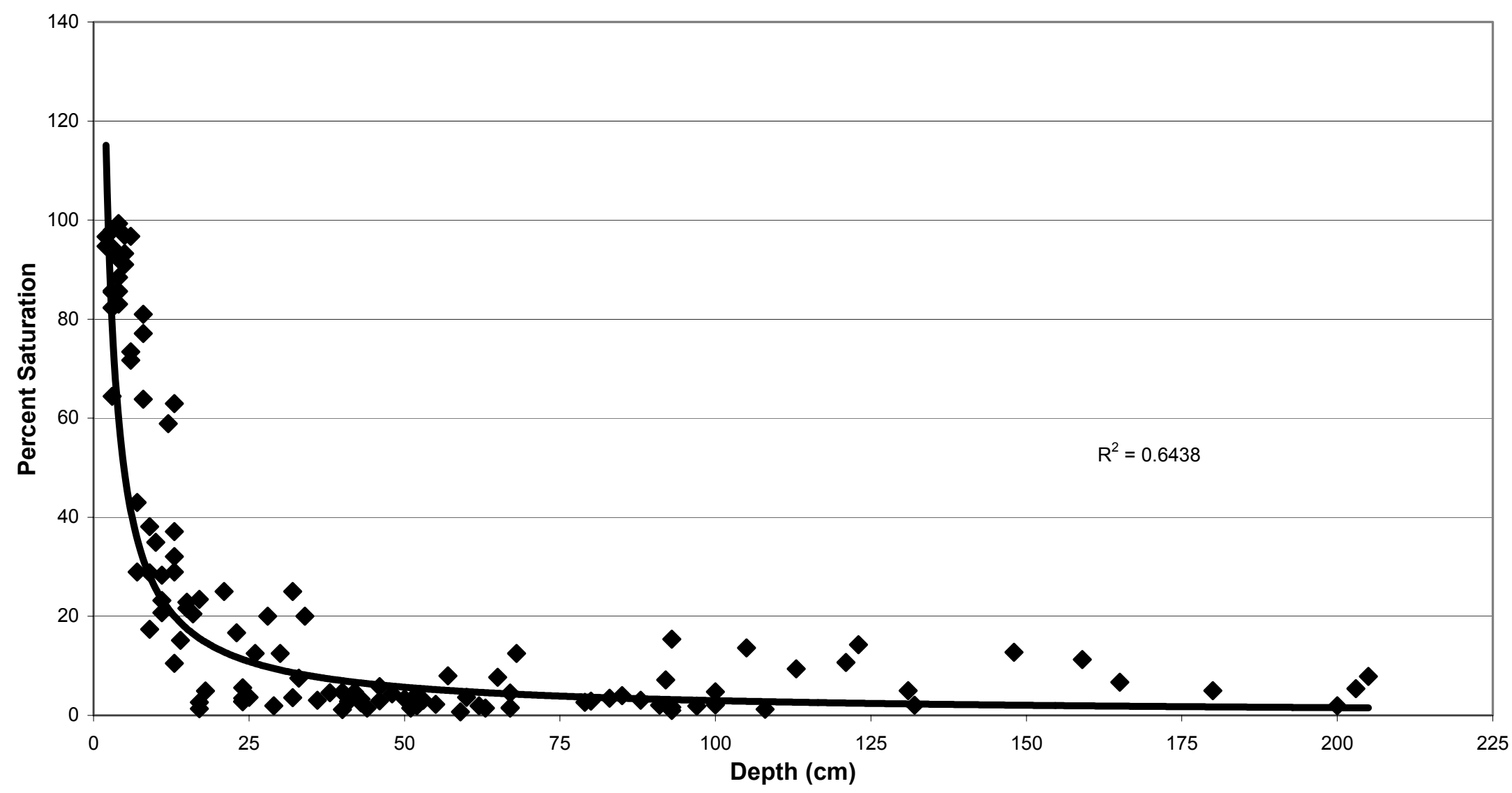

Figure 8.6. Relationship of base saturation of effective cation exchange capacity to soil depth for the series. 


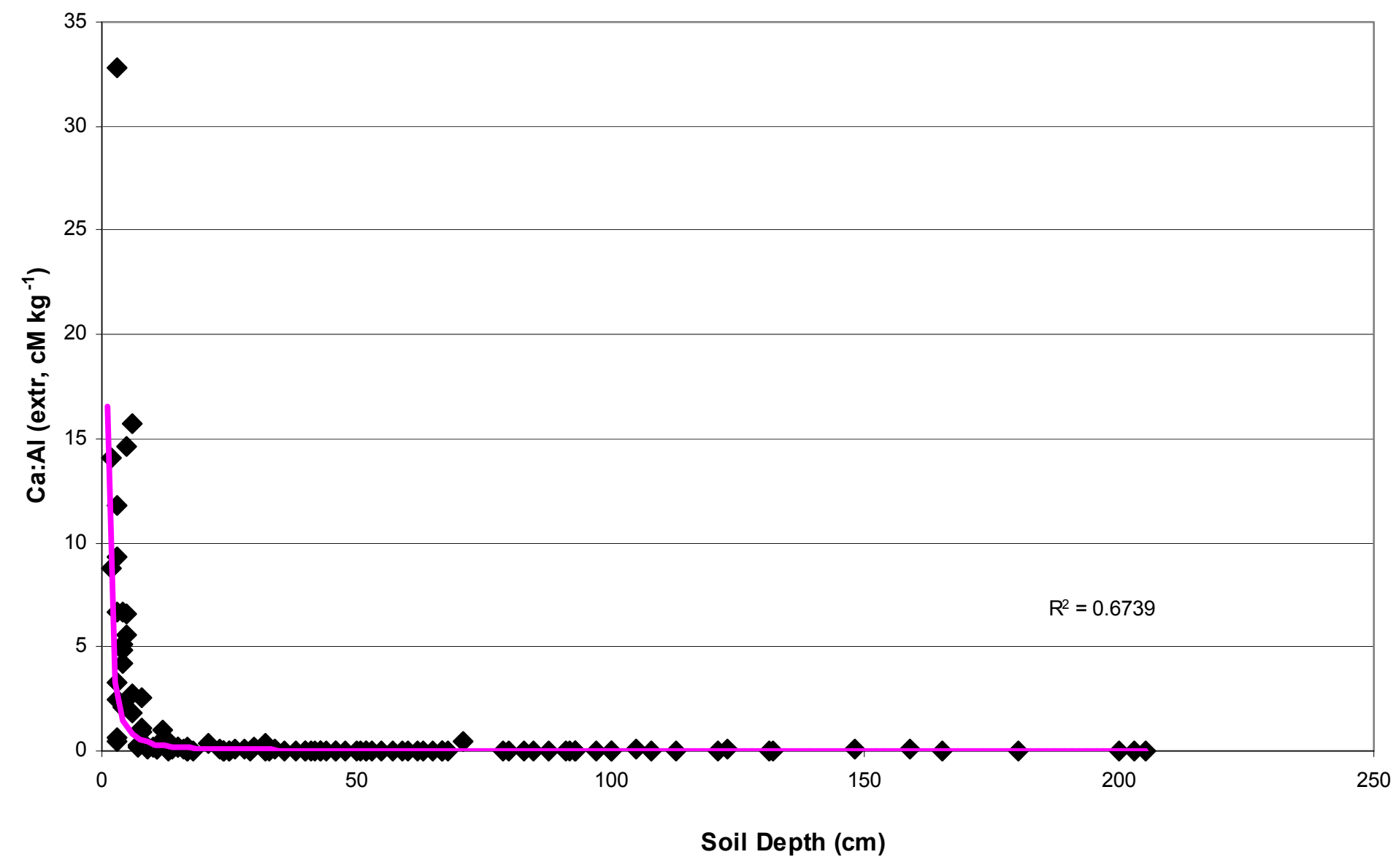

Figure 8.7. Relations hip of extractable Ca:Al to soil depth for the series. 
The importance of SOM to the fertility of these series is hard to overstate, being closely tied to both nutrient retention and acidity mitigation. Inputs of strong acids and their anions, and forest harvesting affect biogeochemical distributions of soil cations through different mechanisms (Johnson, 1995; 1992a; 1992b). Various studies have documented accelerated base cation leaching resulting from increased SOM decomposition, and the mineralization of $\mathrm{Ca}$ and $\mathrm{Mg}$ after forest harvesting (e.g. Hornbeck and Kropelin, 1982; Hornbeck et al., 1986; Mattson and Smith, 1993). Likewise, acid precipitation is likely to increase soil respiration rates due to nitrate additions (Aber et al., 1993; Adams et al., 1997). Among these series, such impacts on biological cycling may be detrimental to forest productivity.

\section{CONCLUSIONS}

These series have total elemental stocks of $\mathrm{Ca}$ and $\mathrm{Mg}$ that are a fraction of other eastern forest soils previously studied, despite the fact that we examined these series to bedrock in most cases. We find that the restriction of the depth of analysis caused significant underestimation of nutrient reserves in the Snowdog series. The presence of uncharacterized reserves of nutrients below sampled horizons may explain some difficulties experienced by other researchers regarding hypotheses of productivity decline or cation depletion (e.g. Johnson et al., 1982; Johnson and Todd, 1999). Given the depths sometimes exploited by tree roots (Stone and Kalisz, 1991), deep soil characterization is important, particularly where nutrient limitations are suspected. In one Snowdog pedon, we observed roots extending below the fragipan to more than 1.5 meters. 
In the context of forest harvesting and acid precipitation, the potential for productivity limitation is conceivable for these series, particularly with regard to calcium. In works compiled by Federer et al. (1989) and Mann et al. (1988), a single whole-tree harvest of northern hardwoods removed more $\mathrm{Ca}\left(537 \mathrm{~kg} \mathrm{ha}^{-1}\right)$ than the total soil Ca stocks for two of the series in our study. Even in the absence of forest harvest, annual watershed leaching losses of Ca may equal from 1 to 3 percent of the total Ca reserves of these series (Adams et al., 1995). It appears that nutrient management considerations are or will be critical to productivity, especially where these series are to be used for forest products. It has been reported that research seeking to focus on characterizing nutrient limitations and response efficiency would be best served by utilizing the most infertile sites (Pastor and Bridgeham, 1999). The initiation of liming trials on areas of these series would likely provide quantitative insight to forest productivity limitation and potential related to $\mathrm{Ca}$ fertility and acidity parameters.

The biogeochemical status of $\mathrm{Ca}$ and $\mathrm{Mg}$ are very different in these series. Total $\mathrm{Ca}$ is closely tied to SOC concentrations, and is relatively extractable, unlike Mg. The concentrations of extractable and total $\mathrm{Ca}$ decline rapidly with soil depth, and are very closely related $\left(\mathrm{R}^{2}>.98\right)$, whereas total Mg increases substantially in the less weathered soil horizons. These phenomena indicate that the Ca reserves of these series are already largely involved in the biological cycle, and the meager geochemical Ca stocks are poorly buffered against leaching. Therefore, mineralogical weathering may be unlikely to replenish sufficient quantities of extractable Ca for sustaining forest productivity. Further mineralogical work on these series may better identify the sources and dynamics of $\mathrm{Ca}$ 
and $\mathrm{Mg}$ reserves, as well as to elucidate relationships between extractable and total pools of base cations.

The Ca:Al ratios and BSECEC also are closely related to SOC concentrations. The rooting environment rapidly deteriorates with depth, usually falling well below "critical" levels of $\mathrm{Ca}: \mathrm{Al}$ and BSECEC within $20 \mathrm{~cm}$.

\section{REFERENCES}

Aber, J.D., A. Magill, R. Boone, J. Mellilo, P. Steudler, and R. Bowden. 1993. Plant and soil responses to chronic nitrogen additions at the Harvard Forest, Massachusetts. Ecol. Applic. 3:156-166.

Adams, M.B., J.A.Burger, A.B. Jenkins, and L. Zelazny. 1999. Impact of harvesting and atmospheric pollution on nutrient depletion of eastern U.S. hardwood forests. For. Ecol. Manage. 138 (1-3): 301-319.

Adams, M.B., T.R. Angradi, and J.N. Kochenderfer. 1997. Stream water and soil solution responses to 5 years of nitrogen and sulfur additions at the Fernow Experimental Forest, West Virginia. For. Ecol. Manage. 95:79-91. 
Adams, M.B., J.N. Kochenderfer, T.R. Angradi, and P.J. Edwards. 1995. Nutrient budgets of two watersheds on the Fernow Experimental Forest. p. 119-130. In

Gottschalk, K.W. and Fosbroke, S.L.C. (ed.) Proc. 10th Central Hardwood Forest Conference. West Virginia University. Morgantown, West Virginia.

Bailey, S.W., Hornbeck, J.W., Driscoll, C.T., Gaudette, H.E. 1996. Calcium inputs and transport in a base poor forest ecosystem as interpreted by Strontium isotopes. Water Resources Research 32 (3):707-719.

CEM Corporation. 1991. Microwave sample preparation system applications manual. App. Note OS-14. Soil. Matthews, NC.

Cronan, C.S. and D.F. Grigal. 1995. Use of calcium/aluminum ratios as indicators of stress in forest ecosystems. J. Environ. Qual. 24:209-226.

David, M.B. and G.B. Lawrence. 1996. Soil and soil solution chemistry under red spruce stands across the northeastern United States. Soil Sci. 161(5):314-328.

Davis, D.D., J.M. Skelly, and B.L. Nash. 1995. Elemental concentrations in foliage of red maple, red oak, and white oak in relation to atmospheric deposition in Pennsylvania. p. 188-195. In Gottschalk, K.W. and Fosbroke, S.L.C. (ed.) Proc. 10th Central Hardwood Forest Conference. West Virginia University. Morgantown, West Virginia. 
Dowdy, S. and S. Weardon. 1991. Statistics for Research. John Wiley and Sons, Inc., New York, NY.

Drohan, J.R. and W.E. Sharpe. 1997. Long-term changes in forest soil acidity in Pennsylvania, U.S.A. Water, Air, Soil Pollut. 95(1-4):299-311.

Ellsworth, D.S., and X. Liu. 1994. Photosynthesis and canopy nutrition of four sugar maple forests on acid soils in northern Vermont. Can. J. For. Res. 24:2118-2127.

Federer, C.A., J.W. Hornbeck, Tritton, L.M., Martin, C.W., Pierce, R.S. and C.T. Smith. 1989. Long-term depletion of calcium and other nutrients in eastern US forests. Environ Manage. 13:593-601.

Gilliam, F.S., and M.B. Adams. 1996. Wetfall deposition and precipitation chemistry for a central Appalachian forest. Can. J. For. Res. 26:196-205.

Hedin, L.O., L. Granat, G.E. Likens, T.A. Buishand, J.N. Galloway, T.J. Butler, and H. Rodhe. 1994. Steep declines in atmospheric base cations in regions of Europe and North America. Nature 367:351-354.

Hendershot, W.H. and F. Courchesne. 1994. Effect of base cation addition on soil chemistry in a sugar maple forest of the Lower Laurentians, Quebec. Can. J. For. Res. 24:609-617. 
Hendershot, W.H. and A. R. C. Jones. 1989. The sugar maple decline in Quebec: a discussion of probable causes and the use of fertilizers to limit damage. For. Chron. $65: 280-287$.

Henderson, G.S. 1995. Soil organic matter: a link between forest management and productivity. p.419-435. In W.W. McFee and J.M. Kelly (ed.) Carbon forms and functions in forest soils. SSSA, Madison, WI.

Hicks, R.R., D. Mudrick, and E. Townsend. 1992. Nutrient fluxes for two small watersheds: seven-year results from the West Virginia University Forest. West Virginia Agricultural and Forestry Experiment Station Bulletin 707. Morgantown, West Virginia.

Hornbeck, J.W., and W. Kropelin. 1982. Nutrient removal and leaching from a wholetree harvest of northern hardwoods. J. Environ. Qual. 11:309-316.

Hornbeck, J.W., C.W. Martin, R.S. Pierce, F.H. Bormann, G.E. Likens, and J.S. Eaton. 1986. Clear-cutting northern hardwoods: Effects on hydrologic and nutrient ion budgets. For. Sci. 32:667-686.

Johnson, C.E., A.H. Johnson, and T.G. Siccama. 1991. Whole-tree clear-cutting effects on extractable cations and soil acidity. Soil Sci. Soc. Am. J. 55:502-508. 
Johnson, D.W. 1992a. Base cations. p. 233-235. In Johnson, D.W., and Lindberg, S. E., (ed.) Atmospheric deposition and forest nutrient cycling. Springer-Verlag, New York.

Johnson, D.W. 1992b. Base cation distribution and cycling. p. 275-340. In Johnson, D.W., and Lindberg, S.E., (ed.) Atmospheric deposition and forest nutrient cycling. Springer-Verlag, New York.

Johnson, D.W. 1995. Role of carbon in the cycling of other nutrients in forested ecosystems. p. 299-328 In W.W. McFee and J.M. Kelly (ed.) Carbon forms and functions in forest soils. SSSA, Madison, WI.

Johnson, D.W., and D.E. Todd. 1987. Nutrient export by leaching and whole-tree harvesting in a loblolly pine and mixed oak forest. Plant Soil. 102:99-109.

Johnson, D.W., and D.E. Todd. 1999. Harvesting effects on long-term changes in nutrient pools of mixed oak forest. Soil Sci. Soc. Am. J. 62:1725-1735.

Johnson, D.W., D.C. West, D.E. Todd, and L.K. Mann. 1982. Effects of sawlog vs. whole-tree harvesting on the nitrogen, phosphorus, potassium, and calcium budgets of an upland mixed oak forest. Soil Sci. Soc. Am. J. 46:1304-1309.

Joslin, J.D., and M.H. Wolfe. 1989. Aluminum effects on northern red oak seedling growth in six forest soil horizons. Soil Sci. Soc. Am. J. 53:274-281. 
Likens, G.E., and F.H.Bormann.1996. Biogeochemistry of a forested ecosystem. $2^{\text {nd }}$ edition, Springer-Verlag, New York.

MacDonald, N.M., A.J. Burton, H.O. Liechty, J.A. Witter, K.S. Pregitzer, G.D. Mroz, and D.D. Richter. 1992. Ion leaching in forest ecosystems along a Great Lakes air pollution gradient. J. Environ. Qual. 21(4):614-623.

Mann, I.K., D.W. Johnson, D.C. West, D.W. Cole, J.W. Hornbeck, C.W. Martin, H. Riekerk, C.T. Smith, W.T. Swank, L.M. Tritton, and D.H. Van Lear. 1988. Effects of whole-tree and stem only clear-cutting on post-harvest hydrologic losses, nutrient capital, and regrowth. For. Sci. 34(2): 412-428.

Mattson, K.G., and H.C. Smith. 1993. Detrital organic matter and soil carbon dioxide efflux in forests regenerating from cutting in West Virginia. Soil Biol. Biochem. 25(9):1241-1248.

Millers, I., Lachance, D., Burkman, W.G., and D.C. Allen. 1991. North American sugar maple decline project: organization and field methods. USDA Forest Service, Gen. Tech. Rep. NE-154, Washington, DC. 
Minocha, R., Shortle, W.C., Lawrence, G.B., David, M.B., and Minocha, S.C. 1997. Relationships among foliar chemistry, foliar polyamines, and soil chemistry in red spruce trees growing across the northeastern United States. Plant Soil. 191(1): 109-122.

National Soil Survey Laboratory Staff, 1996. Soil survey laboratory methods manual. USDA-Natural Resources Conservation Service Soil Survey Invest. Report No. 42, version 3.0. Lincoln, Nebraska.

Pastor, J., and S.D. Bridgham. 1999. Nutrient efficiency along nutrient availability gradients. Oecologia 118: 50-58.

Sharpe, W.E., and T.L. Sunderland. 1995. Acid-base status of upper rooting zone soil in declining and non-declining sugar maple (Acer saccharum) stands in Pennsylvania. p.172-178. In Gottschalk, K.W. and Fosbroke, S.L.C. (ed.) Proc. 10th Central Hardwood Forest Conference. West Virginia University. Morgantown, West Virginia.

Shortle, W.C., K.T. Smith, R. Minocha, G.B. Lawrence, and M.B. David. 1997. Acidic deposition, cation mobilization, and biochemical indicators of stress in healthy red spruce. J. Environ. Qual. 26:871-876.

Shortle, W.C., and K.T. Smith. 1988. Aluminum induced calcium deficiency syndrome in declining red spruce. Science 240:1017-1018. 
Shortle, W.C., K.T. Smith, and W.D. Ostrofsky. 1995. Aluminum and calcium in fine root tips of red spruce collected from the forest floor. Can. J. For. Res. 25:1237-1242.

Stone, E.L., and P.J. Kalisz. 1991. On the maximum extent of tree roots. For. Ecol. Manage. 46:59-102.

Sverdrup, H., P. Warfvinge, and D. Britt. 1995. Assessing the potential for forest effects due to soil acidification in Maryland. Water Air Soil Pollut. 87(1-4):245-265.

USDA. 1981. Major Land Resource Areas of the United States. U.S. Department of Agriculture, Soil Conservation Service. Agricultural handbook 296. Washington, D.C.

Webb, J.R., R.D. Fitzhugh, and T. Furman. 1997. The acid-base status of surface waters in Otter Creek and Dolly Sods Wildernesses. Project completion report to USDA-Forest Service, Monongahela National Forest, Elkins, West Virginia.

Wilmot, T.R., D.S. Ellsworth, and M.T. Tyree. 1995. Relationships among crown condition, growth, and stand nutrition in seven northern Vermont sugarbushes. Can. J.For. Res. 25:386-397. 
Wilmot, T.R., D.S. Ellsworth, and M.T. Tyree. 1996. Base cation fertilization and liming effects on nutrition and growth of Vermont sugar maple stands. For. Ecol. Manage. $84: 123-134$.

Wolt, J. 1994. Soil solution chemistry: applications to environmental science and agriculture. Wiley and Sons, New York. 


\section{CHAPTER NINE}

\section{EXTRACTABLE AND TOTAL PHOSPHORUS OF HIGH ELEVATION FOREST SOILS IN WEST VIRGINIA}

\section{INTRODUCTION}

As much of Appalachia undergoes its second major cycle of hardwood forest harvesting, nutrient issues regarding sustained productivity are receiving attention (Adams et al., 1999; Federer et al., 1989; Mann et al., 1988; Nambiar, 1996). Although most attention has been focused on Ca resources and dynamics (Federer et al., 1998; Johnson and Todd, 1999; Johnson et al., 1982), another important plant nutrient of interest is phosphorus (Kimmins, 1994; Yanai, 1991). Forest soil P reserves and the mechanisms of availability are generally poorly characterized, especially on the Allegheny Plateau of West Virginia.

Phosphorus is considered a plant macronutrient more because of its importance and its common deficiency in intensively managed agricultural systems (Brady and Weil, 1999; Buol et al., 1997) than its relative content in forest biomass. It is typically low in concentration in the bole-wood of trees (Mann et al., 1988), being primarily associated with plant meristematic tissues (Binkley, 1986). Conifers generally have more P per unit biomass than deciduous trees (Vitousek et al., 1988). In forest management, the deficiency of $\mathrm{P}$ has thus far been documented primarily where coniferous forests are intensively managed (Allen et al., 1990; Turner and Lambert, 1986). Although a 
response to $\mathrm{P}$ has been demonstrated for red oak (Quercus rubra L. ) and yellow poplar (Liriodendron tulipifera L) in some West Virginia forest soils (Lamson, 1978), other characteristics of $\mathrm{P}$ deficiency have not been shown.

The occurrence of $\mathrm{P}$ in soils is largely a function of parent material, usually being associated with apatite minerals among carbonates in sedimentary rocks (Dixon and Weed, 1990; Brady and Weil, 1999). Phosphorus, especially extractable P, in soils generally increases with latitude and decreases as soils become more weathered and leached (Smeck, 1985). Locally important P contributions have been demonstrated to come from atmospheric or biotic inputs (Wood et al., 1984). The distribution of available $\mathrm{P}$ in acid forest soils is usually dictated by soil organic matter, where 90 percent or more of labile P often occurs (Seagers et al., 1986; Wood et al., 1984). The distribution of P associated with SOM is largely uncharacterized (Stevenson, 1994), but includes inositol $\mathrm{P}$ and $\mathrm{P}$ associated with aromatic hydrocarbons. The bulk of forest soil $\mathrm{P}$ reserves are usually occluded as $\mathrm{Al}$ and $\mathrm{Fe}$ complexes, and are thermodynamically unavailable over most management time scales (Sposito, 1984; Wolt, 1994). Fortunately, biological mechanisms function to catalyze dissolution of some otherwise unavailable P resources, and in some cases chelate $\mathrm{Al}$ and $\mathrm{Fe}$, thereby preventing $\mathrm{P}$ sorption. The mechanisms of P-interaction of chemicals originating from plant roots, fungal associates, bacteria, and SOM present a subject of excessive complexity and volume for detailed inclusion here. Studies on low molecular weight organic acids and other important substances are reviewed by Fox et al. (1995). Labile P fractions in forest soils are largely dictated by SOM decomposition and faunal activity in forest soils, becoming less associated with low 
molecular weight organic acids and more associated with hydrophobic and aromatic fractions as soil depth increases (Gressel et al., 1996).

The effects of forest harvesting on soil P dynamics are primarily a consequence of the association of $\mathrm{P}$ with SOM. Following harvest, soil moisture and temperature are more favorable for faunal activity, plant uptake is reduced, and P levels increase in soil solution (Yanai, 1991). Yanai (1991) documented downward translocation of soil P after clearcutting of a northern hardwoods forest, where it was subsequently fixed in the subsoil. However, the significance of the translocation is unclear in terms of nutrient quantity, depth of movement, and the degree of fixation (Gressel et al., 1996). Because the activity of noncrystalline $\mathrm{Al}$ and $\mathrm{Fe}$ is high even in the lower $\mathrm{O}$ horizons of some soils, $\mathrm{P}$ does not have to be transported to the subsoil before fixation occurs (Walbridge et al., 1991.) Zhou et al. (1997) found that the metal-organic complexes of Bh horizons sorbed amounts of $\mathrm{P}$ similar to Bt horizons with 2 to 10 times higher clay content. Other work (not associated with forest harvest) has demonstrated that the translocation of $\mathrm{P}$ from forest soils does occur, and is primarily associated with the hydrophobic SOM fraction (Donald et al., 1993). Such translocation has been used to explain the greater $P$ losses of upland soils than those of associated foot-slopes supporting Picea-Abies forests (Donald et al., 1993; Xiao et al. 1991). The effects of harvesting on soil P via soil biota are probably very important, but poorly quantified (Paul and Clark, 1996). Some relevant impacts of clearcutting include reductions in mycorrhizal activity (Moffat, 1991; Perry et al., 1987), organic matter losses on most sites (Edwards and Ross-Todd, 1983; Mattson and Smith, 1993; Mroz et al., 1985), and nitrification increases (Hornbeck et al.,1986; Hornbeck and 
Kropelin, 1982; Mann et al., 1988; Mroz et al., 1985). All of these phenomena are likely to affect soil P forms, distributions, and availability.

Little documentation of the amounts of $\mathrm{P}$ in West Virginia soils exists in the literature. Auchmoody (1972) reviewed forest soils from various parent materials in the state, including Pennsylvanian, Mississippian, and Devonian-era sediments. He reported that extractable P levels were lowest in soils formed from Pennsylvanian sedimentary rocks. The $\mathrm{P}$ values of that study were highly variable, and no total $\mathrm{P}$ levels were reported. Most of the published data on P stocks and distribution for forest soils of this region have been compiled by Federer et al. (1989) and Mann et al. (1988). In their works, they found total soil P reserves to range from $1010 \mathrm{~kg} \mathrm{ha}^{-1}$ (Tennessee oak sites) to $2780 \mathrm{~kg} \mathrm{ha}^{-1}$ (Maine spruce-fir sites), having from 1 to 5 percent of the $\mathrm{P}$ in the forest floor horizons. Forest floor in the cited studies appears to apply only to O horizons. Although labile P may be associated with SOM, the vast majority of total stocks reside in the mineral horizons in these studies. The calculations leading to their estimates were based on soil depths from 0.5 to $1 \mathrm{~m}$.

Federer et al. (1989) and Mann et al. (1988) report that saw-log and whole-tree clearcutting of northern hardwood/spruce sites resulted in the removal of from 4 to $19 \mathrm{~kg} \mathrm{ha}^{-1}$ and 19 to $59 \mathrm{~kg} \mathrm{ha}^{-1} \mathrm{P}$, respectively. These removal rates were a very small portion of total stocks, therefore harvesting was considered unlikely to cause $\mathrm{P}$ deficiency within several rotations. However, given the important relationships of P availability to SOM, the effects of harvesting on SOM pools and dynamics, and the importance of $\mathrm{P}$ to forest 
growth, the understanding of $\mathrm{P}$ fertility in forest soils is incomplete. As noted by Paul and Clark (1996), P limitation in terrestrial ecosystems is typically less a function of total quantities than of the dynamics affecting its availability. I could find no published data including P content of forest biomass from West Virginia.

The forests of the Allegheny Plateau of West Virginia are subject to significant acid precipitation, including nitrate deposition of about $20 \mathrm{~kg} \mathrm{ha}^{-1} \mathrm{yr}^{-1}$ or more (Adams, 1999; Gilliam and Adams, 1996), and many watersheds are N saturated (Adams et al., 1997). Over time, $\mathrm{N}$ deposition likely decreases the availability of $\mathrm{P}$ via increased Al activity and decreased soil pH. Drohan and Sharpe (1997) report that forest floor and upper horizons of major Pennsylvania forest soils are acidifying and levels of extractable Al are increasing, which they suggest is likely caused at least in part by acid precipitation. Acidification and subsequent $\mathrm{Al}$ solubility are also detrimental to $\mathrm{P}$ uptake function and growth of soil fungi and bacteria, perhaps impeding their ability to mediate $\mathrm{P}$ availability to forests (Jongbloed et al., 1992; Paul and Clark, 1996; Thomson and Medve, 1984).

\section{OBJECTIVES}

One objective of this study was to determine the extractable and total P stocks of four frigid series commonly mapped in the high elevation areas of West Virginia. A second objective was to evaluate the distribution of $\mathrm{P}$ with respect to soil organic carbon (SOC) and extractable aluminum. 


\section{MATERIALS AND METHODS}

\section{$\underline{\text { Study Area and Soils }}$}

The study area and soils are described in the preceding chapters of this thesis. Only the frigid series Gauley, MWD Gauley, Mandy, and Snowdog are examined in this work. Pertinent additional information is included below.

\section{Chemical Analyses and Nutrient Stocks}

Each pedon was characterized by horizon for chemical and physical properties, as described in Chapter 3, with all samples analyzed according to standard soil survey procedures (National Soil Survey Laboratory Staff 1996). Analyses pertinent to this chapter include extractable $\mathrm{P}, \mathrm{KCl}$ extractable $\mathrm{Al}, 1: 1 \mathrm{pH}$ in water, and organic carbon percent. Supplemental extractable Al and P analysis, and all total elemental analysis of $\mathrm{P}$ were conducted at the West Virginia Agricultural and Forestry Experiment Station. Total elemental analysis of $\mathrm{P}$ was conducted by nitric acid digestion (EPA method 3051), and analyzed by ICP atomic emission spectrophotometry (ICP-AES, Perkin Elmer, Model 40, Norwaki, CT). Only total P and organic carbon were determined for the litter layer (Oi1) horizons. All nutrient stocks were calculated by horizon, to bedrock or $150 \mathrm{~cm}$, whichever was shallower. We used a one-way analysis of variance (ANOVA) to test for significant differences in $\mathrm{Ca}, \mathrm{Mg}$, and $\mathrm{P}$ content among the series, and then used Least Significant Difference (LSD) to compare adjacent means with a prior significant $F$ value (Dowdy and Weardon, 1991). 


\section{RESULTS AND DISCUSSION}

\section{Extractable and Total Stocks of Phosphorus}

The extractable P (EP) and total P (TP)for the soil series are shown in Table 9.1. The dystrudepts have significantly greater TP stocks than the spodosols, despite the fact that the average EP pools of the spodosols are larger (not statistically significant). We found no statistical difference in the P stocks among the forest floor layers of the series, but the storage of TP is significantly greater in the mineral soil of the dystrochrepts.

The relative amounts of total $\mathrm{P}$ in both the forest floor and mineral soil horizons are generally comparable to those of the studies summarized by Federer et al. (1989) and Mann et al. (1988). This is interesting in regard to the relationship of parent materials to P content. Among the four study sites with total P estimates cited in those publications, soil parent materials included dolomitic limestone, glacial materials, and acid sandstone and shale. We expected to find greater variation among soils of such contrasting parent materials (and age). The actual fine earth volume of these loamy-skeletal series is less than the soils in the referenced studies above. Furthermore, the series of this study have Ca pools that are generally an order of magnitude less than those of Federer et al. (1989) and Mann et al. (1988) (see Chapter 6). Thus, it is difficult to infer whether the levels of $\mathrm{P}$ in these series are a reflection of the content of the parent rock, other inputs, or Pretention mechanisms. It would be desirable if the sampling and analyses methods were more consistent among studies, so that relative ranges of fertility could be established and compared for respective ecosystems. 
Table 9.1. Extractable and total phosphorus for the series.

\begin{tabular}{|c|c|c|c|c|c|c|}
\hline \multirow{2}{*}{$\underline{\text { Series }}$} & \multicolumn{3}{|c|}{ Extractable P } & \multicolumn{3}{|c|}{ Total P } \\
\hline & $\underline{\mathrm{FF}}^{\dagger}$ & $\mathrm{MS}^{\ddagger}$ & $\begin{array}{l}\text { Whole } \\
\text { Pedon }\end{array}$ & $\underline{\mathrm{FF}}$ & $\underline{\mathrm{MS}}$ & $\begin{array}{l}\text { Whole } \\
\text { Pedon }\end{array}$ \\
\hline Mandy & 8.7 & 21.6 & 30.3 & 33.2 & 2089.9 & 2123.0 \\
\hline$(\mathrm{CV})$ & $(.47)$ & $(.68)$ & $(.53)$ & $(.18)$ & $(.40)$ & $(.40)$ \\
\hline \multirow[t]{2}{*}{ Snowdog } & 5.2 & 31.7 & 36.9 & 54.4 & 2470.2 & 2524.6 \\
\hline & $(.43)$ & $(.68)$ & $(.63)$ & $(.98)$ & $(.54)$ & $(.55)$ \\
\hline \multirow[t]{2}{*}{ Gauley } & 9.7 & 40.4 & 50.1 & 57.9 & 833.1 & 891.0 \\
\hline & $(.31)$ & $(1.32)$ & $(1.01)$ & $(.28)$ & $(.52)$ & $(.50)$ \\
\hline \multirow[t]{2}{*}{ MWD Gauley } & 6.9 & 58.8 & 65.7 & 67.6 & 697.2 & 764.8 \\
\hline & $(.30)$ & $(.56)$ & $(.47)$ & $(.44)$ & $(.59)$ & $(.50)$ \\
\hline
\end{tabular}

As would be expected for the coarse-textured spodosols, Gauley and MWD Gauley have the lowest total stocks of P. However, the extractable P reserves of the spodosols are larger (though not statistically) than those of the inceptisols. It is unclear whether this phenomenon is a function of particle size or SOM differences between the two taxa. The 
fine-earth fractions of the spodosols are coarse-loamy, and the inceptisols are fine-loamy, perhaps accounting for more $\mathrm{P}$ fixation in the inceptisol soils. Furthermore, in some horizons of the dystrudepts, clay dispersal is poor and bulk densities are low - indicative of andic soil properties (Soil Survey Staff, 1998). Andic soil properties include the presence of short range-order minerals (usually clay-SOM complexes) that have a high capacity for P fixation. Although the spodosols do not have significantly higher SOC stocks than the inceptisols on an equal-depth basis (see Chapter 7), it is also plausible that a difference in SOM chemistry is responsible for the higher extractable P stocks. The processes of metal complexation and translocation by organic ligands may effectively increase P that is extractable by the Bray method.

While the highest concentrations of extractable $\mathrm{P}$ are associated with the forest floor horizons (Paul and Clark, 1996; Stevenson, 1994), we found only 11 to 29 percent of pedon extractable $\mathrm{P}$ stocks in the $\mathrm{O}$ horizons (Table 9.2). By including $\mathrm{A}$ horizons as forest floor layers, they would contain from a high of 60 percent for the Mandy series, to less than 30 percent for the other series. Nonetheless, the availability of $\mathrm{P}$ in these horizons is high in terms of the relative total P reserves. Only a small fraction of total $\mathrm{P}$ stocks reside in the forest floor of these series (Table 9.2). 
Table 9.2. Percent of pedon extractable and total $P$ found in forest floor horizons ${ }^{\dagger}$ of each series.

\begin{tabular}{lcc}
\hline$\underline{\text { Series }}$ & $\underline{\text { Extractable P }}$ & $\underline{\text { Total P }}$ \\
Mandy & 29 & 2 \\
Snowdog & 14 & 2 \\
Gauley & 19 & 7 \\
MWD Gauley & 11 & 9 \\
\hline
\end{tabular}

The ratio of extractable $\mathrm{P}$ to total $\mathrm{P}$ in these series further illustrates the relative affinities of the mineral soil matrix for $\mathrm{P}$ among the series (Table 9.3). This ratio is from 10 to 26 times higher in the forest floor horizons than in the mineral soil of the dystrochrepts. The influence of upper horizon SOM is not as apparent in the spodosol pedons. 
Table 9.3. Ratios of extractable to total phosphorus for the series.

\begin{tabular}{lcccc}
\hline \multicolumn{1}{l}{ Series } & Forest Floor & & Mineral Soil & Whole Pedon \\
\cline { 2 - 3 } Mandy & .26 & .01 & .01 \\
Snowdog & .10 & .01 & .02 \\
Gauley & .17 & .05 & .06 \\
MWD Gauley & .10 & .08 & .09 \\
\hline
\end{tabular}

Despite the fact that the bulk of the P stocks for these series is not extractable and is located in the mineral soil, EP and TP concentrations are related and correlate strongly with SOC (Figures 9.1 and 9.2). Both EP and TP concentrations decline rapidly with soil depth from the forest floor through the epipedon horizons, then slowly through the subsoil and substrata horizons, as illustrated for the Mandy series (Figure 9.3). All series exhibit similar distribution patterns of $\mathrm{P}$ with depth. These phenomena indicate that SOM is largely responsible for the mediation of availability of P (Henderson, 1995; Johnson, 1995), and is associated with much of the TP stocks throughout the soil profiles of these series. Even in $\mathrm{C}$ horizons immediately above bedrock, $\mathrm{P}$ concentrations usually do not increase. This negative relationship to soil depth, in concert with the SOC relationships, indicates that there is little $\mathrm{P}$ associated with weatherable minerals in the matrices of these soils. Rather, reserves of $\mathrm{P}$ appear to lie predominantly in occluded forms. Both EP and TP concentrations in all series are negatively correlated with Al saturation of CEC (Figure 9.4). Concentrations of P decline through the forest floor and epipedon horizons as $\mathrm{Al}$ saturation approaches 100 percent, then level off. Consistent with the 
work of Xiao et al. (1991) and Gressel et al. (1996), we find high Al saturation and low ratios of EP:TP even in some O horizons. In most pedons of this study, Al saturation does not decrease at depth even as parent materials are approached. Although the nature of the association of $\mathrm{P}$ concentrations to $\mathrm{Al}$ saturation is undoubtedly complex, it appears that decreasing P concentrations accompany the general decrease in buffering with depth among these soils. 


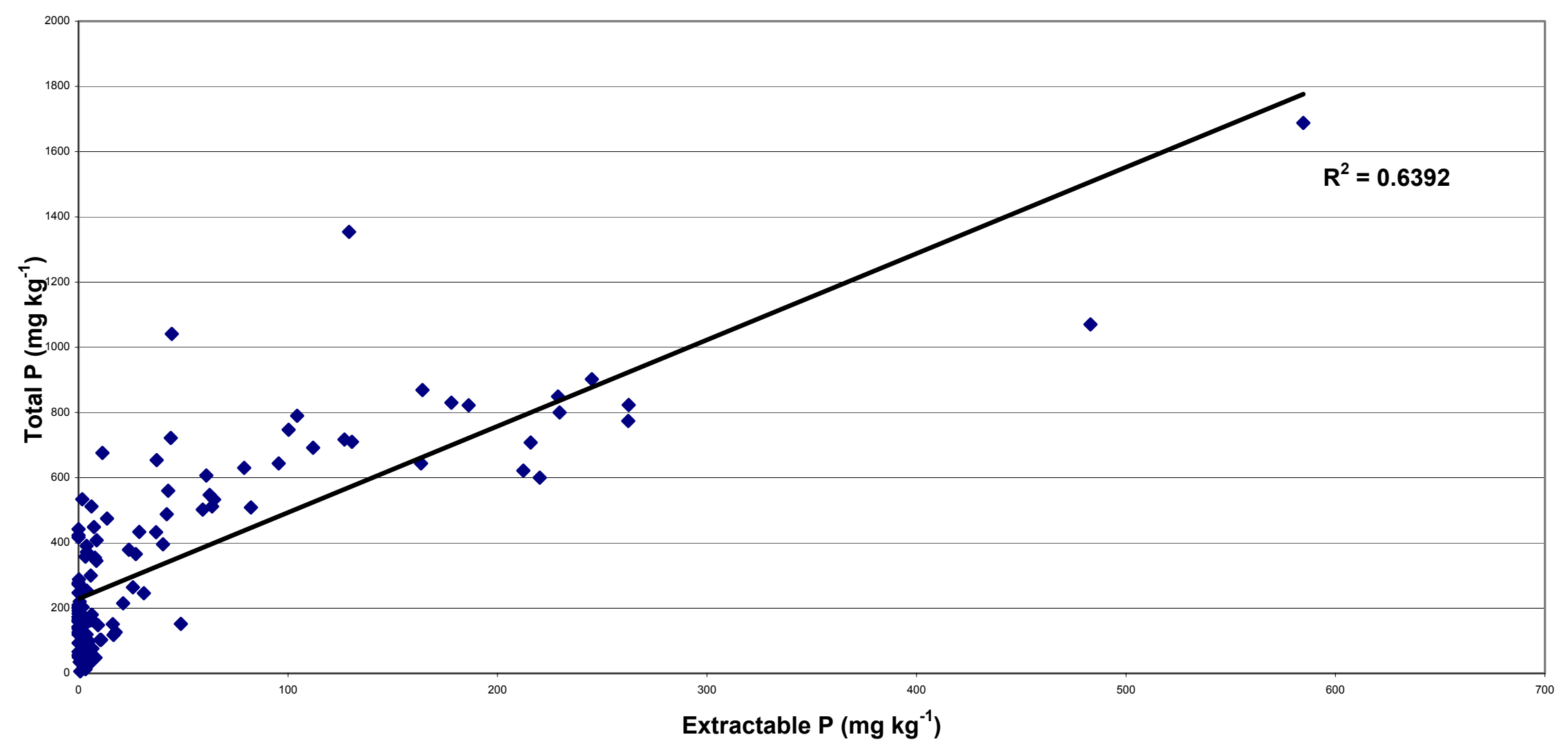

Figure 9.1. Relationship of extractable to total phosphorus for the series. 


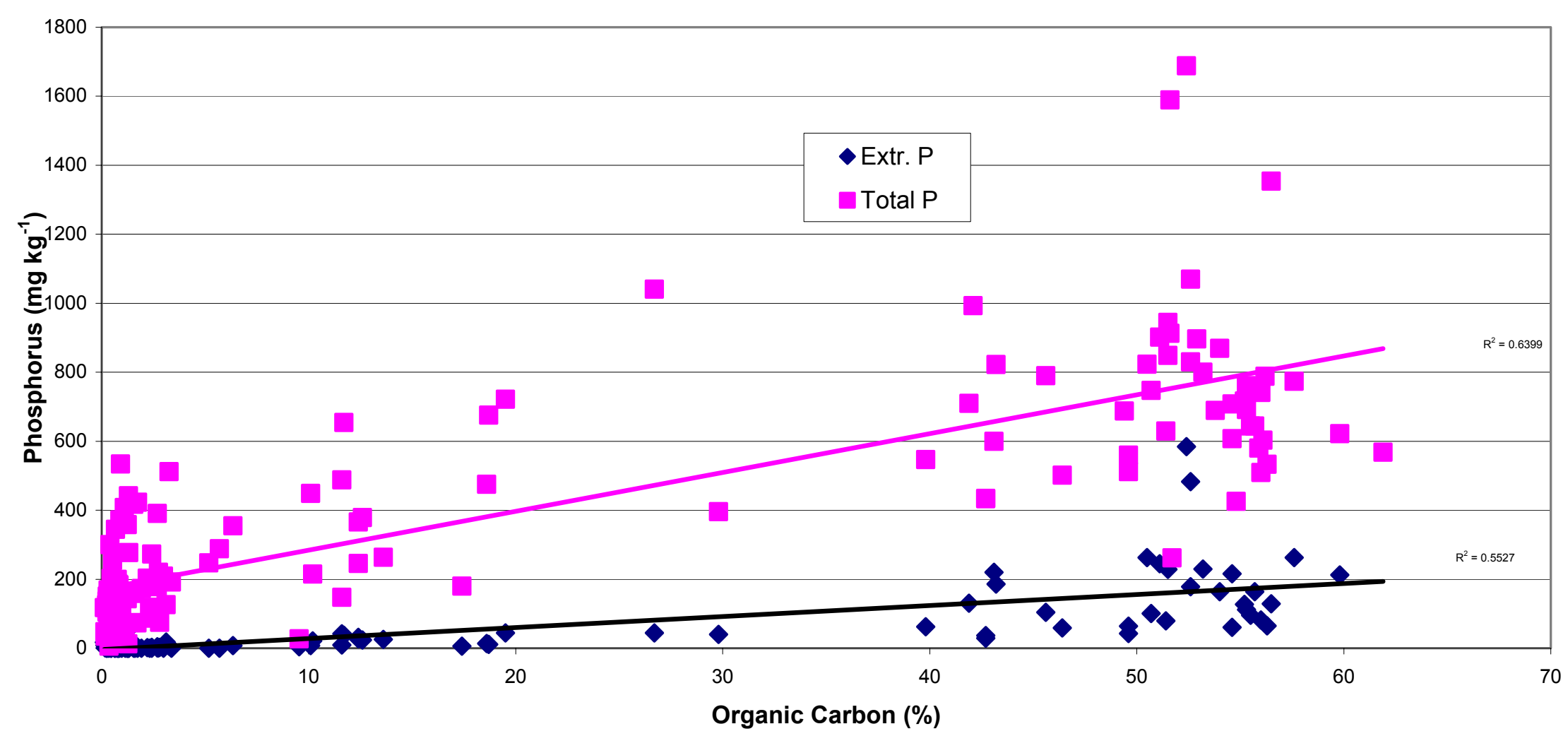

Figure 9.2. Relationship of extractable and total phosphorus to soil organic carbon. 


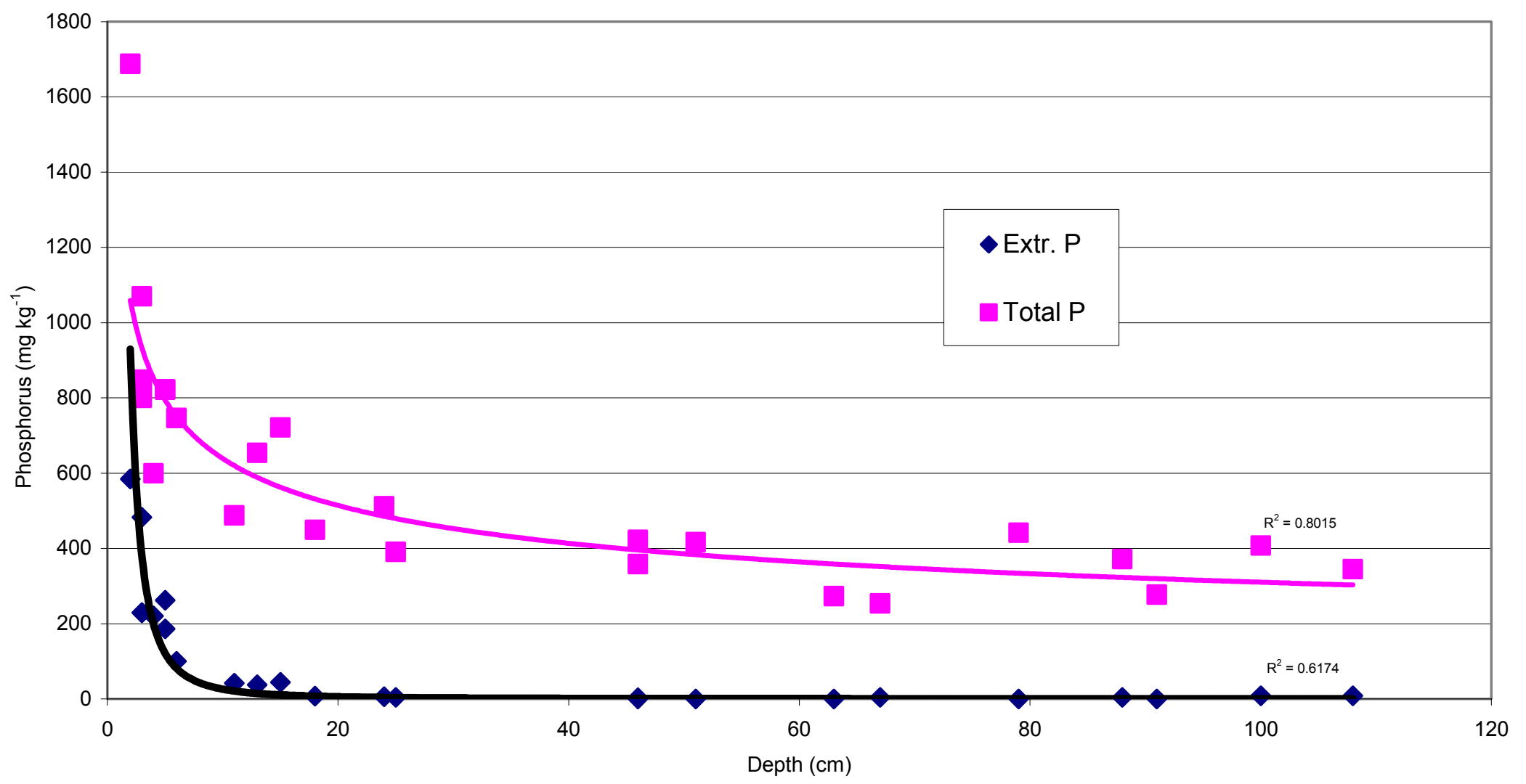

Figure 9.3. Relationship of extractable and total phosphorus to soil depth for the Mandy series. 


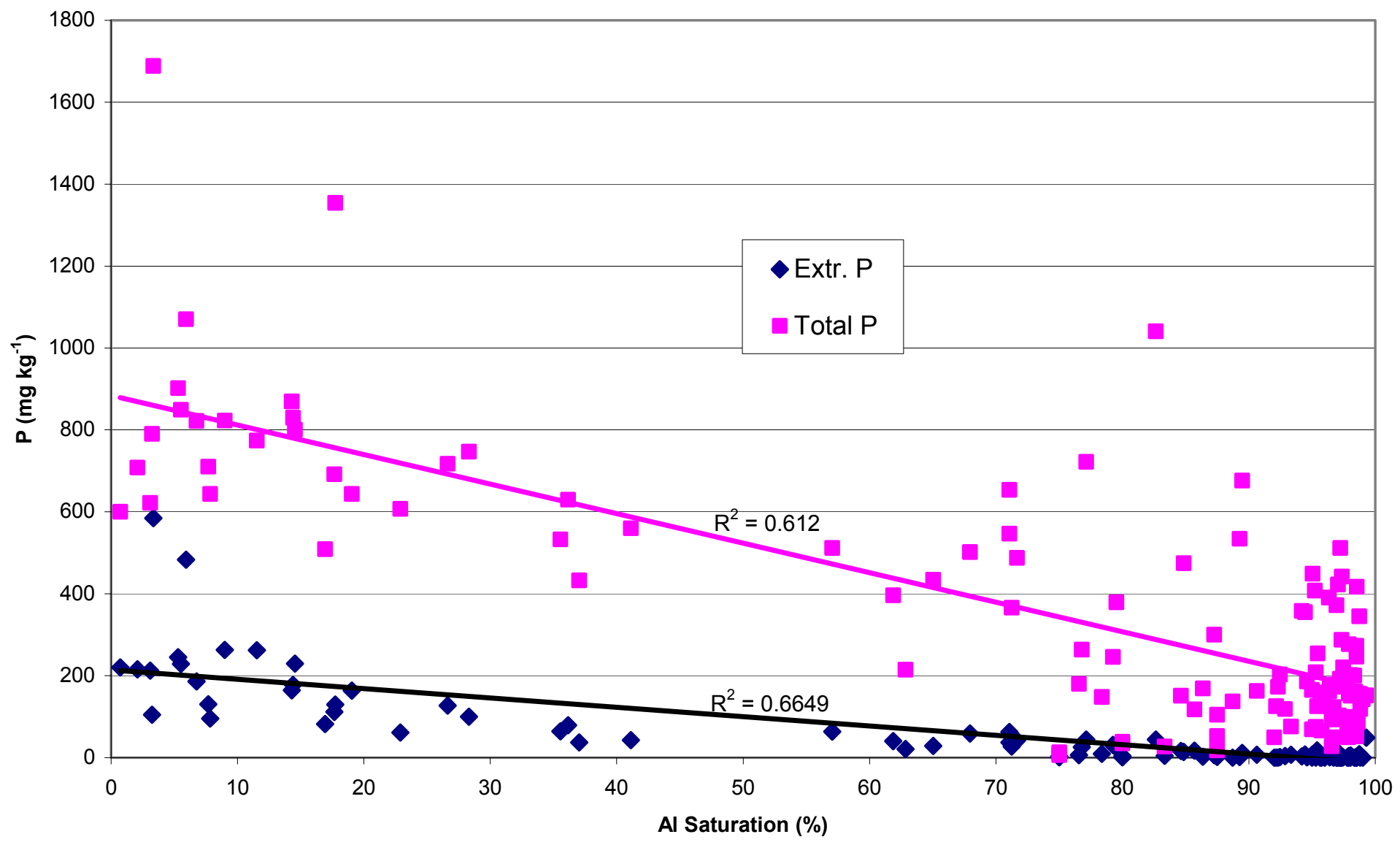

Figure 9.4. Relationship of extractable and total phosphorus to aluminum saturation. 


\section{CONCLUSIONS}

The pools of both EP and TP are closely associated with SOC in these series. The negative correlation with soil depth and extractable Al of both EP and TP indicate that there is little P residing in the weatherable mineral matrix of these series. It appears that the non-labile $\mathrm{P}$ in these soils has already been biologically cycled to some degree, and then sorbed or occluded by various processes typical of extremely acid soils. Although the finer textured dystrudepts have much greater TP reserves than the spodosols, the spodosols exhibit higher levels of EP. The cause of this phenomenon is unclear to us, but may be associated either with short range-order minerals in the dystrudepts or a function of the SOM generated by spruce-dominated vegetation on the spodosols. It appears that soluble $\mathrm{P}$ in these series will tend to be sorbed by Al species, due to the high degree of Al saturation, in concert with the association of P stocks to SOC. The very low Ca stocks of these series further indicate a very low buffering capacity among these series. We cannot demonstrate to what degree, if any, acid precipitation has affected this phenomenon.

With regard to the potential for productivity limitation due to $\mathrm{P}$ deficiency, there is insufficient information published to which the $\mathrm{P}$ fertility of different sites across the region may be compared. If the data compiled by other researchers had been collected to $1 \mathrm{~m}$ or more, the spodosols of this study would likely be somewhat lower in TP stocks, but to an unknown extent. Given the degree of variation among our sites, and the other variables among studies, meaningful statements comparing regional soils cannot be made. Although there are differences in total stocks between the taxa, we do not know 
what difference they make to actual forest productivity. Clearly more information is needed on $\mathrm{P}$ content distribution of forest soils, and about the association of $\mathrm{P}$ fertility to productivity of different forest types. Given the large annual inputs of N, and prior indications of West Virginia forest response to P fertilization (Lamson, 1978), soil amendments that ameliorate acidity and increase extractable P should be studied in these ecosystems. Some European forests impacted by serious acid deposition apparently responded positively to P fertilization in (e.g. Boxman et al., 1994; Ljungstrum and Nihlgard, 1995). Published data for harvest removals indicate that it would take many rotations to affect the TP stocks of these sites. However, given the high degree of acidification, and significant associations of $\mathrm{P}$ to SOC in these soils, harvest impacts on biologically mediated P availability could be substantial.

\section{REFERENCES}

Adams, M.B. 1999. Acidic deposition and sustainable forest management in the Central Appalachians, USA. For. Ecol. Manage. 122(1-2):17-28.

Adams, M.B., J.A.Burger, A.B. Jenkins, and L. Zelazny. 1999. Impact of harvesting and atmospheri c pollution on nutrient depletion of eastern U.S. hardwood forests. For. Ecol. Manage. 138 (1-3): 301-319. 
Adams, M.B., T.R. Angradi, and J.N. Kochenderfer. 1997. Stream water and soil solution responses to 5 years of nitrogen and sulfur additions at the Fernow Experimental Forest, West Virginia. For. Ecol. Manage. 95:79-91.

Allen, H.L., P.M. Dougherty, and R.G. Campbell. 1990. Manipulation of water and nutrients - Practices and opportunities in southern U.S. pine forests. For. Ecol. and Mngmt. 30:437-453.

Auchmoody, L.R. 1972. Nutrient properties of five West Virginia forest soils. In USDA Forest Res. Note NE-145.

Binkley, D. 1986. Forest nutrition management. John Wiley and Sons. New York..

Brady, N.C., and R.R. Weil. 1999. The nature and properties of soils. $12^{\text {th }}$ ed. PrenticeHall, Upper Saddle River, NJ.

Boxman, A.W., L.W. Cobben, and J.G.M. Roelofs. 1994. Does (K+Mg+Ca+P)

fertilization lead to recovery of tree health in a nitrogen stressed Quercus rubra stand? Environmental Pollution 85:297-303.

Buol, S.D., F.D. Hole, and R.J. McCraken. 1997. Soil genesis and classification. $4^{\text {th }}$ edition. Iowa St. Univ. Press. Ames, IA. 
Dixon, J.B., and S.B. Weed. 1990. Minerals in soil environments. SSSA, Madison, WI.

Donald, R. G., D. W. Anderson, and J.W.B. Stewart. 1993. Potential role of dissolved organic carbon in phosphorus transport in forested soils. Soil Sci. Soc. Am. J. 57:16111618.

Dowdy, S. and S. Weardon. 1991. Statistics for research. John Wiley and Sons, Inc., New York, NY.

Drohan, J.R. and W.E. Sharpe. 1997. Long-term changes in forest soil acidity in Pennsylvania, U.S.A. Water, Air, Soil Pollution 95(1-4):299-311.

Dyck, W.J., D.W. Cole, and Comerford, N.B., (Eds). 1994. Impacts of forest harvesting on long-term site productivity. Chapman and Hall. 371p.

Edwards, N.T., and B.M. Ross-Todd. 1983. Soil carbon dynamics in a mixed deciduous forest following clear-cutting with and without residue removal. Soil Sci. Soc. Am. J. 47:1014-1021.

Federer, C.A., J.W. Hornbeck, Tritton, L.M., Martin, C.W., Pierce, R.S. and C.T. Smith. 1989. Long-term depletion of calcium and other nutrients in eastern US forests. Environmental Management 13 (5):593-601. 
Fox, T.R. 1995. The influence of low-molecular-weight organic acids on properties and processes in forest soils p. 43-61. In W.W. McFee and J.M. Kelly (ed.) Carbon forms and functions in forest soils. SSSA, Madison, WI.

Gilliam, F.S., and M.B. Adams. 1996. Wetfall deposition and precipitation chemistry for a central Appalachian forest. J. Air and Waste Manage. Assoc. 46:978-984.

Gressel, N., J.G. McColl, C.M. Preston, R.H. Newman, and R.F. Powers. 1996. Linkages between phosphorus transformations and carbon decomposition in a forest soil. Biogeochemistry 33:97-123.

Henderson, G.S. 1995. Soil organic matter: A link between forest management and productivity. p. 419-435. In W.W. McFee and J.M. Kelly (ed.) Carbon forms and functions in forest soils. SSSA, Madison, WI.

Hornbeck, J.W., and W. Kropelin. 1982. Nutrient removal and leaching from a wholetree harvest of northern hardwoods. J. Environ. Quality 11:309-316.

Hornbeck, J.W., C.W. Martin, R.S. Pierce, F.H. Bormann, G.E. Likens, and J.S. Eaton. 1986. Clear-cutting northern hardwoods: Effects on hydrologic and nutrient ion budgets. For. Sci. 32:667-686. 
Johnson, D.W. 1995. Role of carbon in the cycling of other nutrients in forested ecosystems. p. 299-328. In W.W. McFee and J.M. Kelly (ed.) Carbon forms and functions in forest soils. SSSA, Madison, WI.

Johnson, D.W., and D.E. Todd. 1999. Harvesting effects on long-term changes in nutrient pools of mixed oak forest. Soil Sci. Soc. Am. J. 62:1725-1735.

Johnson, D.W., D.C. West, D.E. Todd, and L.K. Mann. 1982. Effects of sawlog vs whole-tree harvesting on the nitrogen, phosphorus, potassium, and calcium budgets of an upland mixed oak forest. Soil Sci. Soc. Am. J. 46:1304-1309.

Jongbloed, R.H., M.W.A. Tosserams, and G.W.F.H. Borst-Pauwels. 1992. The effect of aluminum on phosphate uptake by three isolated ectomycorrhizal fungi. Plant and Soil 140:167-174.

Kimmins, J.P. 1994. Identifying key processes affecting long term site productivity. p. 119-150. In Dyck, W.J., Cole, D.W., and N.B. Comerford, (ed.) Impacts of forest harvesting on long-term site productivity. Chapman and Hall, London.

Lamson, N.I. 1978. Fertilization increases growth of sawlog size yellow poplar and red oak in West Virginia. USDA For. Serv. Res. Paper NE-403, Broomall, Pennsylvania. 
Ljungstrom, and B. Nihlgard. 1995. Effects of lime and phosphate additions on nutrient status and growth of beech (Fagus sylvatica L.) seedlings. For. Ecol. and Mngmt. $74: 133-148$.

Mann, I.K., D.W. Johnson, D.C. West, D.W. Cole, J.W. Hornbeck, C.W. Martin, H. Riekerk, C.T. Smith, W.T. Swank, L.M. Tritton, and D.H. Van Lear. 1988. Effects of whole-tree and stem only clear-cutting on post-harvest hydrologic losses, nutrient capital, and regrowth. For. Sci. 34 (2): 412-428.

Mattson, K.G., and H.C. Smith. 1993. Detrital organic matter and soil carbon dioxide efflux in forests regenerating from cutting in West Virginia. Soil Biol. and Biochem. 25(9):1241-1248.

Moffat, A.S. 1991. Clear-cutting's soil effects. Science 261:1116.

Nambiar, E.K.S. 1996. Sustained productivity of forests is a continuing challenge to soil science. Soil Sci. Soc. Am. J. 60:1629-1642.

Mroz, G.D., M.F. Jurgensen, and D.J. Frederick. 1985. Soil nutrient changes following whole tree harvesting on hardwood sites. Soil Sci. Soc. Am. J. 49:1552-1557. 
National Soil Survey Laboratory Staff, 1996. Soil Survey Laboratory Methods Manual USDA-Natural Resources Conservation Service Soil Survey Invest. Report No. 42, version 3.0. Lincoln, Nebraska.

Paul, E.A., and F.E. Clark. 1996. Soil Biology and Biochemistry. Academic Press, San Diego, CA.

Perry, D.A., R. Molina, and M.P. Amaranthus. 1987. Mycorrhizae, mycorrhizospheres, and reforestation: Current knowledge and research needs. Can J. For.Res. 17:929-940.

Seagers, J.E., R.A. Minear, J.W. Elwood, and P.J. Mulholland. 1986. Chemical characterization of soluble phosphorus forms along a hydrologic flowpath of a forested stream ecosystem. ORNL/TM-9737. Oak Ridge National Laboratory, Oak Ridge, Tennessee.

Smeck, N.E. 1985. Phosphorus dynamics in soils and landscapes. Geoderma 36:185-199.

Sposito, G. 1984. The surface chemistry of soils. Oxford Univ. Press, New York.

Stevenson, F.J. 1994. Humus Chemistry. 2nd edition John Wiley and Sons, New York.

Thompson, G.W., and E. Medve 1984. Effect of aluminum and manganese on ectomycorrhizae. J. Appl. Environ. Micro. 48:556-560. 
Turner, J., and M.J. Lambert. 1986. Effects of forest harvesting on nutrient removals and soil nutrient reserves. Oecologia 70:140-148.

Twardus, D.B. 1995. Forest health assessment for eastern hardwood forests. p. 3 -10. In Gottschalk, K.W., and Fosbroke, S.L.C. (ed) Proc: 10th central hardwood forest conference. Morgantown, West Virginia.

Vitousek, P.M., T. Fahey, D.W. Johnson, and M.J. Swift. 1988. Element interactions in forest ecosystems: succession, allometry and input-output budgets. Biogeochemistry 5:734.

Walbridge, M.R., C.J. Richardson, and W.T. Swank. 1991. Vertical distribution of biological and geochemical phosphorus subcycles in two southnern Appalachian forest soils. Biogeochemistry 13:61-85.

Wolt, J. 1994. Soil solution chemistry: Applications to environmental science and agriculture, Wiley and Sons. New York.

Wood, T., F.H. Bormann, and G.K. Vogt. 1984. Phosphorus cycling in a northern hardwood forest; biological and chemical control. Science 223:391-393. 
Xiao, X.J., D.W. Anderson, and J.R. Bettany. 1991. The effect of pedogenic processes on the distribution of phosphorus, calcium and magnesium in Gray Luvisol soil. Can. J. Soil Sci. 71:397-410.

Yanai, R.D. 1991. Soil solution phosphorus dynamics in a whole-tree-harvested northern hardwood forest. Soil Sci. Soc. Am. J. 55:1746-1752.

Zhou, M., R.D. Rhue, and W.G. Harris.1997. Phosphorus sorption characteristics of Bh and Bt horizons from sandy coastal plain soils. Soil. Sci. Soc. Am. J. 61:1364-1369. 


\section{CHAPTER TEN \\ COMPREHENSIVE SUMMARY}

This work contains elements of a simple resource inventory survey, documenting SOC, VOC, SMBC, and important nutrient stocks on known and characterized sites.

Additionally, it contains some elements of a relational study, between SOC and fertility characteristics, and between VOC and SMBC and soil/site characteristics.

\section{RESOURCE INVENTORY CONCLUSIONS}

Perhaps most significant among the findings with regard to SOC estimation, is the reinforced importance of the determining factors of calculating areal carbon and nutrient pools. The potential for error resulting from inappropriate $\mathrm{Db}$ methods, and in simply not (historically) accounting for $\mathrm{O}$ horizons has been shown to be tremendous. It is regrettable that this work contains only enough data to render prior $\mathrm{Db}$ methodologies suspect, but is insufficient for locally accurate prediction of upper horizon bulk densities. It is rather common practice in forest soil research to simply excavate volumes of soils from known areas; then weigh and characterize the fine-earth fraction (personal communication from D.W. Johnson, 1999), in order to avoid the difficulties of Db estimation for areal element density measurement. However, this approach does not address how to improve soil survey information, which must provide Db estimates for interpretive uses. This should be a major focus of future work, if carbon and nutrient stocks are of continued interest to soil and forest scientists. 
The SOC and VOC stocks measured in this study are not radically different from modern regional estimates. For SOC, however, the inherent shortcomings within the databases with regard to $\mathrm{Db}$ and $\mathrm{O}$ horizon characterization make for a "moving target" in terms of reconciling individual studies such as this with larger model data (e.g. in Kern, 1994; Post et al. 1982; 1990; Eswaran et al. 1995). These two soil characteristics present a large opportunity for improvement in the predictive utility of USDA soil information for carbon and nutrients.

Soil microbial biomass comprises a significant reservoir of soil organic carbon in the subset of soils and horizons examined. Soil microbial biomass carbon is proportionately greater in the horizons of this study than others cited in works by Paul and Clark (1996) and Horwath (1993). In all cases SMBC composed in excess of four percent of the total soil organic carbon. Organic horizons (Oe) contain significantly more SMBC than do mineral horizons (A or AE), despite the small sample size in this study. The data indicate differences in SMBC between series in like horizons, although the data set is small. More work would likely elucidate differences among series and vegetative cover types.

Data from this study indicate that charcoal or carbolithic-rock may be a source of SOC in some cases. Although average differences were little more than $1 \mathrm{~kg} \mathrm{~m}^{-2}$, larger deviations occur within individual pedons. This is probably not a major problem for larger scale SOC estimation, since it is not likely to cause overestimation of SOC. However, distinguishing charcoal, carbolithic materials, and other SOM could be important in more specific studies (e.g. SOM characterization and litter decomposition 
studies). Certainly, the apparent presence of these SOC forms has undermined the assumption of this author that combustion SOC measurements could essentially be substituted for dichromate (Walkley-Black) measurements simply because carbonates should not be present. It is unknown at this time why combustion measurements are less than dichromate measurements for most upper horizons. Which one of these methods is in error for these horizons is not known to this author. Again, this would need to be resolved before any predictive relationships could be established. Alternative methods to the dichromate procedure are currently of great interest due to the environmental hazards associated with disposal of reagents.

With regard to VOC, a question looms as regards the regression estimation of biomass densities and thus, VOC. Errors for the allometric equations used in this study were generally in the range of $10 \%$ for above-ground biomass estimation where they were developed. It is unknown how accurate they are for the region of this study. Obviously, the calibration of forest biomass estimation techniques is a very difficult, expensive, and invasive endeavor. For the purpose of this study, which is to develop estimates of site VOC primarily to be able to verify the similarity to other forest ecosystems, these equations are probably adequate. If a more accurate assessment of biomass, carbon, or nutrients within forests is needed, then verification may be necessary - as has been done for some oak-dominated forests of West Virginia (e.g. Wiant et al., 1977; 1984; Wiant and Fountain, 1980; Wiant and Wingerd, 1981). 
The actual measurement of site biomass among classes from herbs to trees has promise for more beneficial description of site successional status. As more $\mathrm{C}$ sequestration studies seek to relate soil/site characteristics to biomass, and vice versa, there will be a need to more precisely quantify and understand forest stand development. In addition to the value in describing whether and to what extent a forest is aggrading, characterizing the understory also yields data on a significant portion of site VOC. In this study, $5 \%$ or more of site VOC was associated with saplings, seedlings, shrubs, and herbs. The seasonal variation in the presence of herbaceous vegetation was a phenomenon for which this study was unable to account. On more fertile sites associated with dense wildflower coverage in the spring and early summer, quantities of herbaceous materials may be collectable more than once during the growing season.

\section{RELATIONSHIPS OF SOC, VOC, AND FERTILITY}

This study was not designed to elucidate relationships between productivity (biomass) and fertility characteristics of the series. The sample size was far too small, and the variability in other productivity determining factors was unknown and certainly uncontrolled. No soil characteristics were clearly correlated with biomass growth among these sites. The apparent trend of a negative correlation of total Ca to VOC among the sites is likely deceiving due to the occurrence of anomalously high Ca values at sites that were relatively poorly stocked (in retrospect). 
Nutrient stocks do show a weak trend of correlation with increasing SOC stocks. Again, the small sample size makes it difficult to attribute too much significance to these relationships.

Conversely, the relationships between base cation and SOC concentrations are striking. In the context of the apparently very low Ca reserves, the high degree of Al saturation of the series, and the amount of acid precipitation incident on these sites, these could be the most at-risk sites yet studied with regard to potential $\mathrm{Ca}$ depletion. Calcium and $\mathrm{P}$ exhibit trends of extractable and total concentrations with depth that indicate relatively low geochemical reserves, and a system of minimal mineral buffering capacity. In view of this, the association of SOM with both the extractable and total concentrations of these elements indicates the importance of biogeochemistry in these series. This is further reinforced by the association of SOC with base saturation of ECEC and Ca:Al ratios.

With regard to total elemental analysis, this tool holds much potential for future work in assessing the nutritional status of forest soils. There is a need to understand why that extractable measurements of $\mathrm{Ca}$ and $\mathrm{Mg}$ sometimes exceed total analysis measurements in horizons that are high in SOC. Also there is a need for a standardization of total elemental analysis methodologies among soil scientists.

The SMBC of the organic and mineral horizons show interesting trends implicating fertility and SOM relationships that are likely to be significant to site productivity and carbon sequestration. Closer and more comprehensive examination of the types and 
amounts of soil biota appears likely to yield information of great relevance to applied forest ecology and thus is perhaps the aspect of this work most demanding of further study.

Overall, the results of this work indicate that the high elevation forest soils of West Virginia contain significant organic carbon reserves, and that carbon is intimately tied into the biogeochemical ecology. Little is known about the nutritional requirements of forests, and less is known about the constituents and dynamics of soil organisms in these highly acidic forest soil environments. Hopefully this work provides a preliminary picture of the fundamental biogeochemical environment where the phenomena which determine forest productivity occur.

\section{REFERENCES}

Eswaran, H., I. Van den Berg, P.Reich, and J. Kimble. 1995. Global soil carbon resources. p. 27-43 In R. Lal et al. (ed.) Soils and global change. CRC Press, Boca Raton, FL.

Horwath, W.R. 1993. The dynamics of carbon, nitrogen, and soil organic matter in a Populus plantation. Ph.D. Thesis. Michigan State University, East Lansing.

Kern, J.S. 1994. Spatial patterns of soil organic carbon distribution in the contiguous United States. Soil Sci. Soc. Am. J. 58: 439-455. 
Paul, E.A., and F.E. Clark. 1996. Soil Biology and Biochemistry. Academic Press, San Diego, CA 340p.

Post, W.M., W.R. Emanuel, P.J. Zinke, and A.G. Stangenberger. 1982. Soil carbon pools and world life zones. Nature 298:156-159.

Post, W.M., T.H. Peng, W.R. Emanuel, A.W. King, V.H. Dale, and D.L. De Angelis. 1990. The global carbon cycle. Am. Sci. 78:310-326.

Wiant, H.V., Jr., C.E. Sheetz, A. Colaninno, J.C. DeMoss, and F. Castaneda. 1977. Tables and procedures for estimating weights of some Appalachian hardwoods. WV Agr. For. Exp. Sta. Bull. 659T. Morgantown, WV. 36 p.

Wiant, H.V., Jr., R. Knight, and J.E. Baumgras. 1984. Relation of biomass to basal area and site index on an Appalachian watershed. Res. Note NE-315. USFS Northeastern Forest Exp. Sta., Broomall, PA. 4 p.

Wiant, H.V., Jr., and M.S. Fountain. 1980. Oak site index biomass yield in upland oak and cove hardwood timber types in West Virginia. USFS Res. Note NE-291. USFS Northeastern For. Exp. Res. Sta., Broomall, PA. 2 p.

Wiant, H.V., Jr., and D.E. Wingerd. 1981. Biomass factors for point sampling in Appalachian hardwoods. J. For. 79(1):21-29. 
APPENDIX A

\section{PEDON DESCRIPTIONS AND SITE INFORMATION}




\section{APPENDIX A. PEDON DESCRIPTION AND SITE INFORMATION.}

\section{Soil Series: Blackwater (tentative)}

Site Identification \#: 95WV083008

Date Sampled: 10/11/1995

Map Unit Symbol: 148C

Lab Pedon \#: 96P0085 Source Lab Id: NSSL

MLRA: 127

County Name: Randolph

Soil Survey Area Name: Randolph High Elevation Study

Location Description: $182 \mathrm{~m}$ south of USFS road 324 about $3.70 \mathrm{~km}$ north of the Yellow Creek entrance to Otter Creek Wilderness Area.

Quadrangle Name: Bowden

Latitude: 38 degrees 58 minutes 59 seconds $\mathrm{N}$

Longitude: 79 degrees 41 minutes 47 seconds W

Photograph \#: 3222-79

Slope Characteristics Information

Slope: $1 \%$

Horizontal Shape: linear

Vertical Shape: linear

Total Slope Length: $120 \mathrm{~m}$

Slope Length Above Site: $50 \mathrm{~m}$

Elevation: $1173 \mathrm{~m}$

Physiography:

Local: Plateau

Major: Mountains

Microrelief:

Kind: tree throw feature

Elevation: $20 \mathrm{~cm}$

Runoff: Low

Moisture Regime: Udic

Landuse: Forest land not grazed

Permeability: Very slow

Natural Drainage Class: Somewhat poorly drained

Parent material: Residuum from sandstone-shale

Vegetative Information: Red spruce, yellow birch, C. hemlock, red maple.

Particle Size Control Section: 25 to $100 \mathrm{~cm}$

Diagnostic Features: ochric, 0 to $20 \mathrm{~cm}$

cambic, 42 to $55 \mathrm{~cm}$

fragic soil properties, 55 to $108 \mathrm{~cm}$ 
Current series classification: none; tentatively Aquic Fragiudepts

Pedon classification (Soil Survey Staff, 1998; 1999): loamy-skeletal, siliceous, semiactive, frigid Fragiaquic Dystrudept

Described by: Jenkins, Delp

Oil -2 to $0 \mathrm{~cm}$. Rock transect $=29.5 \% .96 \mathrm{P} 0847$

Oi2--0 to $3 \mathrm{~cm}$; common fine and medium roots throughout. 96P0848

Oe-3 to $6 \mathrm{~cm}$; many fine and medium roots throughout. 96P0849

$\mathrm{Oa}-6$ to $13 \mathrm{~cm}$; black (N 2/0), mucky loam; many fine to coarse roots throughout; clear wavy boundary. 96P 0850

A-13 to $20 \mathrm{~cm}$; very dark gray (7.5YR 3/1), very channery loam; weak fine and medium subangular blocky structure; very friable; many fine to coarse roots throughout; $5 \%$ subangular sandstone-shale gravel and 35\% subangular sandstone-shale channers and $15 \%$ subangular sandstone-shale flagstones; clear wavy boundary. 96P0851

A/E -20 to $42 \mathrm{~cm} ; 50 \%$ very dark gray ( $7.5 \mathrm{YR} 3 / 1)$, broken face, and $50 \%$ light brownish gray (10YR 6/2), broken face, very channery sandy loam; common fine and medium distinct brownish yellow (10YR 6/8) redox concentrations throughout; weak medium subangular blocky structure; firm; few fine and medium roots between peds; $5 \%$ subangular sandstone-shale gravel and 35\% subangular sandstone-shale channers and $15 \%$ subangular sandstone-shale flagstones; clear wavy boundary. 96P0852

Bw-42 to $55 \mathrm{~cm}$; brown (10YR 5/3), very channery loam; many medium distinct brownish yellow (10YR 6/8) redox concentrations throughout and many fine and medium distinct light brownish gray (10YR 6/2) redox depletions throughout; weak medium subangular blocky structure; friable; few roots; $10 \%$ subangular sandstone-shale gravel and $15 \%$ subangular sandstone-shale channers and $20 \%$ subangular sandstone-shale flagstones; gradual wavy boundary. $96 \mathrm{P} 0853$

Bx-55 to $108 \mathrm{~cm} ; 80 \%$ brown (10YR 5/3) and 20\% yellowish brown (10YR 5/6), very channery sandy loam; common medium distinct grayish brown (10YR 5/2) redox depletions on ped surfaces; weak coarse prismatic structure; very firm; $5 \%$ subangular sandstone-shale gravel and $20 \%$ subangular sandstone-shale channers and $15 \%$ subangular sandstone-shale flagstones; gradual wavy boundary. 96P0854

$\mathrm{BCx}-108$ to $134 \mathrm{~cm}$; dark yellowish brown (10YR 4/4), broken face, very channery coarse sandy loam; common fine faint yellowish brown (10YR 5/6) redox concentrations throughout and common fine distinct grayish brown (10YR 5/2) redox depletions throughout; weak coarse prismatic structure parting to weak medium platy; very firm; $10 \%$ subangular sandstone-shale gravel and $20 \%$ subangular sandstone-shale channers and $20 \%$ subangular sandstone-shale 
flagstones; abrupt broken boundary. 96P0855

$\mathrm{R}-134 \mathrm{~cm}$. Sandstone bedrock.

\section{Soil Series: Blackwater (tentative) \\ Site Identification \#: 95WV093001}

Date Sampled: 7/31/1995

Map Unit Symbol: 148C

Lab Pedon \#: 95P0852 Source Lab Id: NSSL

MLRA: 127

County Name: Tucker

Soil Survey Area Name: Tucker High Elevation Study

Location Description: $2.41 \mathrm{~km}$ out USFS road 717 from US219 north of

Parsons. About $152 \mathrm{~m}$ northeast of the Olson

Knob fire tower, $61 \mathrm{~m}$ east of USFS717, $46 \mathrm{~m}$ north east of hiking trail 117.

Quadrangle Name: Mozark Mountain

Latitude: 39 degrees 6 minutes 28.2 seconds $\mathrm{N}$

Longitude: 79 degrees 35 minutes 56.9 seconds $\mathrm{W}$

Photograph \#: 3222-87

Slope Characteristics Information

Slope: $6 \%$

Horizontal Shape: linear

Vertical Shape: Concave

Total Slope Length: $100 \mathrm{~m}$

Slope Length above Site: $30 \mathrm{~m}$

Elevation: $1099 \mathrm{~m}$

Physiography:

Local: Plateau

Major: Mountains

Microrelief:

Kind: tree throw feature

Elevation: $25 \mathrm{~cm}$

Water Table Information

Water Table Depth: $33 \mathrm{~cm}$

Water Table Kind: Perched

Flooding Information Ponding Information

Frequency: None Frequency: None

Runoff: Low

Classification: loamy-skeletal, siliceous, frigid, Aquic Fragiochrepts

Moisture Regime: Udic

Landuse: Forest land not grazed

Stoniness: $15 \%$ 
Permeability: Slow

Natural Drainage Class: Somewhat poorly drained

Parent material: Residuum from sandstone-shale

Bedrock information:

Weathering: slightly

Hardness: hard

Kind: sandstone-shale

Vegetative Information: Dominantly red spruce and hemlock, with red maple, and yellow birch codominant.

Particle Size Control Section: 25 to $100 \mathrm{~cm}$

Diagnostic Features: ochric, 0 to $15 \mathrm{~cm}$

albic, 15 to $33 \mathrm{~cm}$

fragic soil properties, 33 to $85 \mathrm{~cm}$

Current series classification: none; tentatively Aquic Fragiudepts

Pedon classification (Soil Survey Staff, 1998; 1999): loamy-skeletal, siliceous, semi-

active, frigid Fragiaquic Dystrudept

Described by: Jenkins, Jim Gorman (WVU).

Notes: Site sampled with Bob Grossman from NSSC.

Oil--2 to $0 \mathrm{~cm}$. Field number 1 for the 1995 Soil Organic Carbon study. Rock transect $=$ $29.5 \% .95 \mathrm{P} 5379$

Oi2--0 to $3 \mathrm{~cm}$; many fine to coarse roots throughout; clear smooth boundary.95P5380

Oe--3 to $6 \mathrm{~cm}$; many fine to coarse roots throughout; clear smooth boundary.95P5381

Oa--6 to $12 \mathrm{~cm}$; black (N 2/0), sapric material; many fine to coarse roots throughout; clear smooth boundary.95P5382

A--12 to $15 \mathrm{~cm}$; black (10YR 2/1), mucky sandy loam and channery sandy loam; weak fine and medium granular structure; very friable; many fine to coarse roots throughout; $15 \%$ rounded conglomerate gravel and $15 \%$ subangular sandstone channers; abrupt smooth boundary. 95P5383

E--15 to $33 \mathrm{~cm}$; brown (7.5YR 5/2), gravelly loamy sand; weak medium subangular blocky structure; firm, brittle; few roots; $15 \%$ rounded conglomerate gravel and $15 \%$ subangular sandstone channers; clear wavy boundary. 95P5384

Bx1--33 to $56 \mathrm{~cm}$; brown (10YR 5/3), very gravelly sandy loam; many coarse distinct light brownish gray (10YR 6/2) redox depletions on ped surfaces and many medium distinct strong brown (7.5YR 4/6) redox concentrations throughout; weak coarse prismatic structure parting to weak medium subangular blocky; very firm, apparently cemented by silica, brittle; few roots; $20 \%$ rounded conglomerate gravel and $15 \%$ 
subangular sandstone channers; gradual wavy boundary. Some pockets of sandy clay loam textures noted. 95P5385

Bx2--56 to $85 \mathrm{~cm}$; brown (10YR 5/3), very gravelly sandy loam; many coarse distinct light brownish gray (10YR 6/2) redox depletions on ped surfaces and many medium distinct strong brown (7.5YR 4/6) redox concentrations throughout; weak coarse prismatic structure parting to weak medium subangular blocky; firm, brittle; few roots; $25 \%$ rounded conglomerate gravel and $20 \%$ subangular sandstone channers; clear wavy boundary. 95P5386

Cg--85 to $119 \mathrm{~cm}$; grayish brown (10YR 5/2), very gravelly coarse sandy loam and channery sandy loam; common fine distinct yellowish brown (10YR 5/6) redox concentrations throughout; massive; firm, few roots; $20 \%$ rounded conglomerate gravel and 25\% subangular sandstone channers; abrupt wavy boundary. $95 \mathrm{P} 5387$

$\mathrm{R}--119 \mathrm{~cm}$. 


\section{Soil Series: Gauley}

\section{Site Identification \#: 95WV075001}

Date Sampled: 10/17/1995

Lab Pedon \#: 96P0079

Source Lab Id: SSL

MLRA: 127

County Name: Pocahontas

Soil Survey Area Name: Pocahontas County Soil Survey

Location Description: Cranberry Wilderness Area, Sugar Creek Mtn., about $1.13 \mathrm{~km}$ from Sugar Creek Mtn parking

area on west side of the Scenic Highway about $4.02 \mathrm{~km}$ south of Williams River.

Quadrangle Name: Sharp Knob

Latitude: 38 degrees 18 minutes 7 seconds $\mathrm{N}$

Longitude: 80 degrees 15 minutes 14 seconds $\mathrm{W}$

Slope Characteristics Information

Slope: $2 \%$

Horizontal Shape: linear

Vertical Shape: linear

Total Slope Length: $90 \mathrm{~m}$

Slope Length Above Site: $50 \mathrm{~m}$

Elevation: $1350 \mathrm{~m}$

Physiography:

Local: Plateau

Major: Mountains

Geomorphic Position: on upper third, summit, of a head slope

Microrelief:

Kind: micro depression

Pattern: no

Flooding Information Ponding Information

Frequency: None Frequency: None

Runoff: Low

Moisture Regime: Udic

Landuse: Forest land not grazed

Stoniness: $20 \%$

Permeability: Moderately rapid

Natural Drainage Class: Well drained

Parent material: Residuum from sandstone

Bedrock information:

Weathering: moderately

Hardness: soft

Kind: sandstone-siltstone

Vegetative Information

Plant Name: red spruce 
Particle Size Control Section: 25 to $100 \mathrm{~cm}$

Diagnostic Features: ochric, 0 to $11 \mathrm{~cm}$

albic, 11 to $26 \mathrm{~cm}$

spodic, 26 to $38 \mathrm{~cm}$

cambic, 38 to $93 \mathrm{~cm}$

Current series classification: loamy-skeletal, siliceous, frigid, Typic Haplorthods

Pedon classification (Soil Survey Staff, 1998; 1999): loamy-skeletal, siliceous, superactive, frigid Typic Haplorthod.

Described by: Tony Jenkins, Don Flegel, Rob Pate

Notes: Site is near prior pedon description for establishment of the

series by D. Flegel. Site is bouldery, though map unit is

generally rubbly.

Oi1 -1 to $0 \mathrm{~cm}$. Rock transect $=45 \%$. NSSL ID 96P0797

Oi2--0 to $3 \mathrm{~cm}$; common fine roots throughout; gradual wavy

boundary. 96P0798

Oa-3 to $7 \mathrm{~cm}$; black (10YR 2/1), channery mucky sandy loam; common fine to coarse roots throughout; $15 \%$ subangular sandstone-shale channers and $10 \%$ subangular sandstone-shale flagstones; clear wavy boundary. 96P0799

A-7 to $11 \mathrm{~cm}$; black (10YR 2/1), very channery

sandy loam; weak medium and coarse granular structure; friable; many

fine to coarse roots throughout; $5 \%$ subangular sandstone-shale gravel and $15 \%$

subangular sandstone-shale channers and $20 \%$ subangular sandstone-shale flagstones;

abrupt wavy boundary. 96P0800

E-11 to $26 \mathrm{~cm}$; $80 \%$ light brownish gray (10YR 6/2),

and $20 \%$ dark grayish brown (10YR 4/2), very channery loamy fine sand; weak fine and medium subangular blocky structure; friable; few fine to coarse roots throughout; $15 \%$ subangular sandstone-shale gravel and $15 \%$ subangular sandstone-shale channers and 20\% subangular sandstone-shale flagstones; abrupt wavy boundary. 96P0801

$\mathrm{Bh} / \mathrm{Bhs}-26$ to $38 \mathrm{~cm} ; 70 \%$ dark reddish brown (5YR 3/2), and $15 \%$ strong brown (7.5YR 4/6), and $15 \%$ dark reddish brown (5YR $3 / 3$ ), very channery loam; weak medium subangular blocky structure; friable; few fine and medium roots throughout; $5 \%$ subangular sandstone-shale gravel and $20 \%$ subangular sandstone-shale channers and $10 \%$ subangular sandstone-shale flagstones; gradual irregular boundary. Some inconsistently expressed Bs material occurs in the lower part of this horizon. 96P0802

Bw-38 to $60 \mathrm{~cm}$; $50 \%$ yellowish brown (10YR 5/4), and 25\% brown (7.5YR 4/4), and $25 \%$ dark yellowish brown (10YR 4/4), very channery sandy loam; weak medium subangular blocky structure; friable; few fine and medium roots throughout; $10 \%$ 
subangular sandstone-shale gravel and 25\% subangular sandstone-shale channers and $10 \%$ subangular sandstone-shale flagstones; clear wavy boundary. 96P0803

BC-60 to $93 \mathrm{~cm}$; $80 \%$ yellowish brown (10YR 5/6), and 20\% brownish yellow (10YR $6 / 6$ ), very channery loamy sand; weak fine and medium subangular blocky structure; firm; few roots; $10 \%$ subangular sandstone-shale gravel and 30\% subangular sandstoneshale channers and $10 \%$ subangular sandstone-shale flagstones; gradual wavy boundary. 96P0804

C -93 to $123 \mathrm{~cm}$; brownish yellow (10YR 6/6), very channery loamy sand; single grain; loose; few roots; $10 \%$ subangular sandstone-shale gravel and 30\% subangular sandstoneshale channers and $10 \%$ subangular sandstone-shale

flagstones; clear wavy boundary. 96P0805

$2 \mathrm{Cr}-123 \mathrm{~cm}$. Weathered siltstone/fine grained sandstone.

\section{Soil Series: Gauley}

\section{Site Identification \#: 95WV075002}

Date Sampled: 10/23/1995

Lab Pedon \#: 96P0080 Source Lab Id: NSSL

County Name: Pocahontas

Soil Survey Area Name: Pocahontas County Soil Survey

Location Description: 150 m northwest of the Bald Knob lookout tower adjacent to the Cass Scenic Railroad State Park.

Quadrangle Name: Cass

Latitude: 38 degrees 26 minutes 55 seconds $\mathrm{N}$

Longitude: 79 degrees 55 minutes 57 seconds W

Slope Characteristics Information

Slope: $2 \%$

Horizontal Shape: linear

Vertical Shape: linear

Total Slope Length: $100 \mathrm{~m}$

Slope Length above site: $0 \mathrm{~m}$

Elevation: $1462 \mathrm{~m}$

Physiography:

Local: Plateau

Major: Mountains

Geomorphic Position: on upper third, summit, of a head slope

Flooding Information Ponding Information

Frequency: None Frequency: None

Runoff: Low

Moisture Regime: Udic

Landuse: Forest land not grazed 
Stoniness: $15 \%$

Permeability: Moderately rapid

Natural Drainage Class: Well drained

Parent material: Residuum from sandstone-shale

Vegetative Information: Red spruce overwhelming dominant and thick from canopy to ground cover.

Particle Size Control Section: 25 to $93 \mathrm{~cm}$

Diagnostic Features: ochric, 0 to $13 \mathrm{~cm}$

albic, 13 to $25 \mathrm{~cm}$

spodic, 25 to $41 \mathrm{~cm}$

cambic, 41 to $62 \mathrm{~cm}$

Current series classification: loamy-skeletal, siliceous, frigid, Typic Haplorthods

Pedon classification (Soil Survey Staff, 1998; 1999): loamy-skeletal, siliceous, superactive, frigid Typic Haplorthod.

Described by: Jenkins, Flegel, Delp

Oi1-1 to $0 \mathrm{~cm}$; clear wavy boundary. Rock transect $==67 \% .96 \mathrm{P} 0806$

Oi2--0 to $3 \mathrm{~cm}$; clear wavy boundary. 96P0807

Oe-3 to $8 \mathrm{~cm}$; common fine and medium roots throughout; clear wavy boundary. 96P0808

Oa- 8 to $13 \mathrm{~cm}$; black (5YR 2/1), channery mucky peat; many fine to coarse roots throughout; $20 \%$ subangular sandstone-shale channers and 5\% subangular sandstoneshale flagstones; clear wavy boundary. 96P0809

E-13 to $25 \mathrm{~cm} ; 90 \%$ brown (7.5YR 5/2), and $10 \%$ brown (7.5YR 4/2), very channery very fine sandy loam; weak medium subangular blocky structure; firm in place, friable when removed, (some evidence of cementation by silica; common fine and medium roots throughout; $30 \%$ subangular sandstone-shale channers and 5\% subangular sandstoneshale flagstones; clear wavy boundary. About $2 \mathrm{~cm}$ or less of zone at top of $\mathrm{E}$ horizon is transitional to $\mathrm{Oa}$ (AE horizon too thin to sample). 96P0810

Bhs -25 to $33 \mathrm{~cm} ; 70 \%$ dark reddish brown (5YR 3/2), and 10\% strong brown (7.5YR $5 / 6)$, and $20 \%$ brown (7.5YR 4/2), channery very fine sandy loam; weak medium subangular blocky structure; friable; few fine and medium roots throughout; $20 \%$ subangular sandstone-shale channers and 5\% subangular sandstone-shale flagstones; clear wavy boundary. 96P0811

Bs-33 to $41 \mathrm{~cm}$; strong brown (7.5YR 4/6), channery fine sandy loam; weak fine and medium subangular blocky structure; friable; $25 \%$ subangular sandstone-shale channers and 5\% subangular sandstone-shale flagstones; clear wavy boundary. 96P0812

$\mathrm{Bw}-41$ to $62 \mathrm{~cm}$; yellowish brown (10YR 5/6), very channery fine sandy loam; weak fine and medium subangular blocky structure; friable; $45 \%$ subangular sandstone-shale 
channers and 5\% subangular sandstone-shale flagstones; gradual wavy boundary. $96 \mathrm{P} 0813$

C-62 to $93 \mathrm{~cm}$; yellowish brown (10YR 5/6), extremely channery fine sandy loam; massive; friable; $55 \%$ subangular sandstone-shale channers and $15 \%$ subangular sandstone-shale flagstones; abrupt broken boundary. 96P0814

$\mathrm{R}-93 \mathrm{~cm}$; Fractured sandstone.

\section{Soil Series: Gauley}

\section{Site Identification \#: 95WV083003}

Date Sampled: 8/3/1995

Map Unit Symbol: 40C

Lab Pedon \#: 95P0857 Source Lab Id: NSSL

Soil Survey Area \#: $083 \quad$ MLRA: 127

County Name: Randolph

Soil Survey Area Name: Randolph High Elevation Study

Location Description: $122 \mathrm{~m}$ west of old fire tower foundation above Dolly Sods picnic area. Probably a few meters south of the Tucker Co. line.

Quadrangle Name: Hopeville

Latitude: 38 degrees 57 minutes 49.6 seconds $\mathrm{N}$

Longitude: 79 degrees 21 minutes 32.4 seconds $\mathrm{W}$

Photograph \#: 3216-100

Slope Characteristics Information

Slope: $3 \%$

Horizontal Shape: Convex

Vertical Shape: linear

Total Slope Length: $100 \mathrm{~m}$

Slope Length Above Site: $20 \mathrm{~m}$

Elevation: $1253 \mathrm{~m}$

Physiography:

Local: Plateau

Major: Mountains

Microrelief:

Kind: micro depression

Flooding Information

Ponding Information

Frequency: None

Frequency: None

Runoff: Medium

Moisture Regime: Udic

Landuse: Forest land not grazed

Stoniness: $20 \%$ 
Permeability: Rapid

Natural Drainage Class: Well drained

Parent material: Residuum from sandstone-shale

Vegetative Information: Red spruce, Yellow birch, Red maple

Particle Size Control Section: 25 to $68 \mathrm{~cm}$

Diagnostic Features: ochric, 0 to $17 \mathrm{~cm}$

albic, 17 to $28 \mathrm{~cm}$

spodic, 28 to $53 \mathrm{~cm}$

Current series classification: loamy-skeletal, siliceous, frigid, Typic Haplorthods

Pedon classification (Soil Survey Staff, 1998; 1999): loamy-skeletal, siliceous, superactive, frigid Typic Haplorthod.

Described by: Jenkins, Sencindiver, Pyle.

Notes: Site sampled with Bob Grossman.

Oil--1 to $0 \mathrm{~cm}$. Rock transect $=17 \% .95 \mathrm{P} 5431$

Oi2--0 to $5 \mathrm{~cm}$; many very fine to coarse roots throughout; clear smooth boundary. 95P5432

Oe--5 to $8 \mathrm{~cm}$; many very fine to coarse roots throughout; clear wavy boundary. 95P5433

A--8 to $13 \mathrm{~cm}$; black (10YR 2/1), mucky loamy sand and extremely channery; weak medium and coarse granular structure; very friable; many very fine to coarse roots throughout; 5\% subangular sandstone gravel and 45\% subangular sandstone channers and $20 \%$ subangular sandstone flagstones; clear broken boundary. 95P5434

AE--13 to $17 \mathrm{~cm}$; 80\% dark grayish brown (10YR 4/2), and 20\% very dark gray (10YR $3 / 1$ ), extremely channery fine sandy loam; weak medium subangular blocky structure; very friable; many fine to coarse roots throughout; $5 \%$ subangular sandstone gravel and $45 \%$ subangular sandstone channers and 20\% subangular sandstone flagstones; clear wavy boundary. 95P5435

E--17 to $28 \mathrm{~cm}$; 50\% grayish brown (10YR 5/2), and 50\% brown (10YR 5/3), very channery loamy fine sand; weak medium subangular blocky structure; very friable; common fine and medium roots between peds; $5 \%$ subangular sandstone gravel and 40\% subangular sandstone channers and 15\% subangular sandstone flagstones; abrupt wavy boundary. 95P5436

Bh--28 to $34 \mathrm{~cm}$; very dark gray (5YR 3/1), very channery loam; weak medium subangular blocky structure; friable; common medium roots between peds; $5 \%$ subangular sandstone gravel and 35\% subangular sandstone channers and 10\% subangular sandstone flagstones; clear wavy boundary. 95P5437

Bhs--34 to $40 \mathrm{~cm} ; 40 \%$ dark reddish brown (5YR 3/2), and 40\% dark reddish brown (5YR $3 / 3$ ), and $20 \%$ reddish brown (5YR 4/4), very channery sandy loam; weak medium 
subangular blocky structure; friable; common fine and medium roots between peds; $10 \%$ subangular sandstone gravel and 40\% subangular sandstone channers; clear wavy boundary. 95P5438

Bhs/BC--40 to $53 \mathrm{~cm} ; 20 \%$ dark reddish brown (5YR 3/2), and 20\% reddish brown (5YR $4 / 4$ ), and 20\% dark reddish brown (5YR 3/4), and 40\% strong brown (7.5YR 4/6), very channery fine sandy loam; weak medium subangular blocky structure; very friable; common fine and medium roots between peds and few fine throughout; $10 \%$ subangular sandstone gravel and 35\% subangular sandstone channers and 15\% subangular sandstone flagstones; clear broken boundary. 95P5439

C--53 to $68 \mathrm{~cm}$; $50 \%$ strong brown (7.5YR 4/6), and 50\% dark yellowish brown (10YR 4/6), extremely channery sandy loam; massive; very friable; $10 \%$ subangular sandstone gravel and 40\% subangular sandstone channers and 20\% subangular sandstone flagstones; abrupt wavy boundary. 95P5440

$\mathrm{R}--68 \mathrm{~cm}$.

\section{Soil Series: Gauley}

\section{Site Identification \#: 95WV093007}

Date Sampled: 9/12/1995

Map Unit Symbol: 40C

Lab Pedon \#: 96P0089 Source Lab Id: NSSL

Soil Survey Area \#: 093 MLRA: 127

County Name: Tucker

Soil Survey Area Name: Tucker High Elevation

Location Description: Weiss Knob about $.81 \mathrm{~km}$ southeast of Canaan

Ski Resort upper lift stations.

Quadrangle Name: Laneville

Latitude: 38 degrees 59 minutes 38 seconds $\mathrm{N}$

Longitude: 79 degrees 25 minutes 47 seconds W

Photograph \#: 3216-99

Slope Characteristics Information

Slope: $3 \%$

Horizontal Shape: linear

Vertical Shape: Convex

Total Slope Length: $50 \mathrm{~m}$

Slope Length Above Site: $75 \mathrm{~m}$

Elevation: $1352 \mathrm{~m}$

Physiography:

Local: Knoll

Major: Mountains

Flooding Information Ponding Information 
Frequency: None Frequency: None

Runoff: Low

Classification: loamy-skeletal, siliceous, frigid, Typic Haplorthods

Moisture Regime: Udic

Landuse: Forest land not grazed

Permeability: Rapid

Natural Drainage Class: Well drained

Parent material: Residuum from sandstone

Vegetative Information: Red spruce, yellow birch, C. hemlock, red maple.

Particle Size Control Section: 25 to $100 \mathrm{~cm}$

Diagnostic Features: ochric, 0 to $15 \mathrm{~cm}$

albic, 15 to $50 \mathrm{~cm}$

spodic, 50 to $67 \mathrm{~cm}$

cambic, 67 to $93 \mathrm{~cm}$

Current series classification: loamy-skeletal, siliceous, frigid, Typic Haplorthods

Pedon classification (Soil Survey Staff, 1998; 1999): loamy-skeletal, siliceous, superactive, frigid Typic Haplorthod.

Described by: Jenkins, Jim Gorman

Notes: Extremely thick spruce cover, from herb layer to dominant

overstory. Many down trees, but most broken off, not treethrow

as is more common in MWD sites with cemented albic.

Oi1--1 to $0 \mathrm{~cm}$. Rock transects $=51.5 \% .96 \mathrm{P} 0881$

Oi2--0 to $4 \mathrm{~cm}$; clear wavy boundary. $96 \mathrm{P} 0882$

Oe- -4 to $6 \mathrm{~cm}$; many very fine to coarse roots throughout;

clear wavy boundary. 96P0883

$\mathrm{Oa} / \mathrm{A}-6$ to $12 \mathrm{~cm}$; black (N 2/0), extremely channery sapric material and extremely channery sandy loam; weak fine granular structure; very friable; many very fine to coarse roots

throughout; 5\% subangular sandstone-shale gravel and 50\% subangular sandstone-shale channers and 20\% subangular sandstone-shale gravel; clear wavy boundary. 96P0884

AE - 12 to $15 \mathrm{~cm}$; dark gray (10YR 4/1), extremely channery loamy sand; weak fine granular structure; very friable; many very fine to coarse roots matted around stones; $50 \%$ subangular

sandstone-shale channers and 5\% subangular sandstone-shale gravel and 20\% subangular sandstone-shale flagstones; abrupt wavy boundary. 96P0885

E-15 to $50 \mathrm{~cm} ; 60 \%$ grayish brown (10YR 5/2), 20\% pale brown (10YR 6/3), and 20\% gray (10YR 5/1), extremely channery loamy fine sand; weak fine and medium subangular blocky structure; very friable; common fine and medium roots matted around stones; $5 \%$ subangular sandstone-shale gravel and $50 \%$ subangular sandstone-shale channers and $20 \%$ subangular sandstone-shale flagstones; abrupt wavy boundary. 96P0886 
$\mathrm{Bh} / \mathrm{Bhs}-50$ to $67 \mathrm{~cm} ; 70 \%$ black (5YR 2/1), 20\% dark reddish brown (5YR 3/3), and $10 \%$ dark brown (7.5YR 3/4), very channery loam; weak medium subangular blocky structure; friable; common very fine to coarse roots throughout; $5 \%$ subangular sandstone-shale gravel and 30\% subangular sandstone-shale channers and 10\% subangular sandstone-shale flagstones; clear wavy boundary. 96P0887

Bw-67 to $93 \mathrm{~cm} ; 90 \%$ dark yellowish brown (10YR 4/6), and 10\% dark yellowish brown (10YR 4/4), broken face, extremely channery fine sandy loam; weak medium subangular blocky structure; friable; few fine and medium roots throughout; 5\% subangular sandstone-shale gravel and 50\% subangular sandstone-shale channers and $20 \%$ subangular sandstone-shale flagstones; gradual wavy boundary. 96P0888

C—93 to $113 \mathrm{~cm}$; yellowish brown (10YR 5/4), extremely channery fine sandy loam; massive; very friable; few fine roots throughout; 5\% subangular sandstone-shale gravel and 35\% subangular sandstone-shale channers and 15\% subangular sandstone-shale flagstones; abrupt broken boundary. 96P0889

$\mathrm{R} / \mathrm{C}-113 \mathrm{~cm}$; Fractured sandstone bedrock with sandy loam soil in the voids $(<10 \%)$. 


\section{Soil Series: MWD Gauley}

\section{Site Identification \#: 95WV083002}

Date Sampled: 8/3/1995

Map Unit Symbol: 140C

Lab Pedon \#: 95P0856 Source Lab Id: NSSL

MLRA: 127

County Name: Randolph

Soil Survey Area Name: Randolph High Elevation

Location Description: Stuart Knob site. $152 \mathrm{~m}$ west of the Little Black Fork Trail, 243 m north of USFS Road between Bear Heaven and Stuart Knob.

Quadrangle Name: Bowden

Latitude: 38 degrees 56 minutes 20.1 seconds N

Longitude: 79 degrees 42 minutes 14.6 seconds W

Photograph \#: 3222-56

Slope Characteristics Information

Slope: $4 \%$

Horizontal Shape: linear

Vertical Shape: linear

Total Slope Length: $138 \mathrm{~m}$

Slope Length Above Site: $100 \mathrm{~m}$

Elevation: $1193 \mathrm{~m}$

Physiography:

Local: Plateau

Major: Mountains

Microrelief:

Kind: tree throw feature

Elevation: $15 \mathrm{~cm}$

Runoff: Medium

Moisture Regime: Udic moisture regime

Landuse: Forest land not grazed

Stoniness: $15 \%$

Permeability: Moderate

Natural Drainage Class: Moderately well drained

Parent material: Residuum from sandstone-shale

Vegetative Information: Red spruce, Yellow birch, Red maple

Particle Size Control Section: 25 to $71 \mathrm{~cm}$

Diagnostic Features: ochric, 0 to $21 \mathrm{~cm}$

albic, 21 to $32 \mathrm{~cm}$

spodic, 32 to $52 \mathrm{~cm}$

Current series classification: none, anticipated as Aquic Haplorthods

Pedon classification (Soil Survey Staff, 1998; 1999): loamy-skeletal, siliceous, active, frigid Typic Epiaquod

Described by: J. Sencindiver, T. Jenkins. 
Notes: Mature spruce and thick spruce understory. Sampled with Bob Grossman. Not placic.

Oi1 --0 to $2 \mathrm{~cm}$. Rock transect $=36 \%$. 95P5421

Oi2--0 to $4 \mathrm{~cm} .95 \mathrm{P} 5422$

Oe--4 to $8 \mathrm{~cm}$; many very fine to coarse roots throughout. 95P5423

Oa/A--8 to $13 \mathrm{~cm}$; black (N 2/0), mucky loam; weak fine and medium granular structure; very friable; many very fine to coarse roots throughout; $5 \%$ subangular sandstone channers; abrupt wavy boundary. 95P5424

AE--13 to $21 \mathrm{~cm}$; dark gray (10YR 4/1), very channery sandy loam; weak fine subangular blocky structure parting to weak fine and medium granular; very friable; common fine to coarse roots throughout; $10 \%$ rounded conglomerate gravel and $30 \%$ subangular sandstone-shale channers; clear wavy boundary. 95P5425

E--21 to $32 \mathrm{~cm}$; brown (7.5YR 4/2), very gravelly loamy coarse sand; weak coarse subangular blocky structure; firm; common fine to coarse roots between peds; $10 \%$ rounded conglomerate gravel and 30\% subangular sandstone-shale channers; abrupt wavy boundary. 95P5426

Bh--32 to $40 \mathrm{~cm}$; dark reddish brown (5YR 2/2), gravelly coarse sandy loam; weak fine and medium subangular blocky structure; friable; few very fine to medium roots throughout; $15 \%$ well rounded conglomerate gravel and 5\% subangular sandstone-shale channers; clear wavy boundary. 95P5427

Bh/Bs--40 to $52 \mathrm{~cm} ; 50 \%$ strong brown (7.5YR 5/8), and 30\% dark brown (7.5YR 3/2), and $15 \%$ yellowish red (5YR 5/8), and 5\% black (N 2/0), gravelly coarse sandy loam; common fine and medium distinct brown (7.5YR 4/2) and dark reddish brown (5YR 3/2) redox depletions; weak medium and coarse subangular blocky structure; friable; few very fine to medium roots between peds; $20 \%$ rounded conglomerate gravel and $10 \%$ subangular sandstone-shale channers; clear wavy boundary. 95P 5428

Bs--52 to $57 \mathrm{~cm}$; strong brown (7.5YR 5/6), very gravelly loamy coarse sand; few medium distinct brown (7.5YR 5/2) redox depletions; weak coarse subangular blocky structure; friable; few roots; $40 \%$ rounded conglomerate gravel and $20 \%$ subangular sandstone-shale channers; clear wavy boundary. 95P5429

C--57 to $71 \mathrm{~cm} ; 50 \%$ yellowish brown (10YR 5/4), and 50\% yellowish brown (10YR $5 / 6$ ), extremely gravelly loamy coarse sand; massive; friable; $50 \%$ rounded conglomerate gravel and 25\% subangular sandstone-shale channers; clear wavy boundary. 95P5430

$\mathrm{R}--71 \mathrm{~cm}$. 


\section{Soil Series: MWD Gauley}

\section{Site Identification \#: 95WV083006}

Map Unit Name: mwd Gauley, 3-15\% slopes, rubbly.

Date Sampled: 9/18/1995

Map Unit Symbol: 140C

Lab Pedon \#: 96P0083 Source Lab Id: NSSL

MLRA: 127

County Name: Randolph

Soil Survey Area Name: Randolph High Elevation Study

Location Description: About 243 m southeast of USFS road 324 about

$4.02 \mathrm{~km}$ north of the Yellow Cr. entrance to

Otter Creek Wilderness.

Quadrangle Name: Bowden

Latitude: 38 degrees 59 minutes 2 seconds $\mathrm{N}$

Longitude: 79 degrees 41 minutes 37 seconds W

Photograph \#: 3222-79

Slope Characteristics Information

Slope: $1 \%$

Horizontal Shape: linear

Vertical Shape: linear

Total Slope Length: $100 \mathrm{~m}$

Slope Length Above Site: $0 \mathrm{~m}$

Elevation: $1189 \mathrm{~m}$

Physiography:

Local: Plateau

Major: Mountains

Microrelief:

Kind: tree throw feature

Elevation: $15 \mathrm{~cm}$

Runoff: Low

Type of Erosion: water erosion

Degree of Erosion: Class 1

Moisture Regime: Udic

Landuse: Forest land not grazed

Permeability: Moderately slow

Natural Drainage Class: Moderately well drained

Parent material: Residuum from sandstone

Vegetative Information: Red spruce

Particle Size Control Section: 25 to $100 \mathrm{~cm}$

Diagnostic Features: folistic epipedon, 0 to $17 \mathrm{~cm}$

albic, 23 to $44 \mathrm{~cm}$

spodic, 44 to $59 \mathrm{~cm}$

Current series classification: none, anticipated as Aquic Haplorthods 
Pedon classification (Soil Survey Staff, 1998; 1999): loamy-skeletal, siliceous, active, frigid Typic Epiaquod Described by: Jenkins, S.Carpenter

Notes: Tree throw a problem here, cemented slowly permeable albic.

Oi1 -1 to $0 \mathrm{~cm}$. Rock transect $=12 \%$, but thick $\mathrm{O}$ horizons and root density certainly a major factor. 96P0832

Oi2--0 to $3 \mathrm{~cm}$; many fine to coarse roots throughout; clear smooth boundary. 96P0833

Oe-3 to $10 \mathrm{~cm}$; many fine to coarse roots throughout; clear smooth boundary. 96P0834

$\mathrm{Oa}-10$ to $17 \mathrm{~cm}$; black (N 2/0), sapric material; very friable; common fine and medium roots throughout; clear smooth boundary. 96P0835

A-17 to $23 \mathrm{~cm}$; black (10YR 2/1), channery sandy loam; weak fine subangular blocky structure; very friable; common fine and medium roots throughout; $15 \%$ subangular sandstone-shale channers and 5\% subangular sandstone-shale flagstones; clear wavy boundary. $96 \mathrm{P} 0836$

E-23 to $30 \mathrm{~cm} ; 70 \%$ light brownish gray (10YR 6/2), broken face, and 30\% light gray (10YR 7/1), channery loamy coarse sand; weak medium and coarse subangular blocky structure; firm; few roots; $5 \%$ subrounded sandstone-shale gravel and $25 \%$ subangular sandstone-shale channers; clear wavy boundary. 96P0837

EB-30 to $44 \mathrm{~cm} ; 70 \%$ reddish gray (5YR 5/2), broken face, and 30\% dark brown (7.5YR 3/2), channery coarse sandy loam; weak medium and coarse subangular blocky structure; firm; $5 \%$ subrounded sandstone-shale gravel and $25 \%$ subangular sandstone-shale channers; abrupt wavy boundary. 96P0838

Bh-44 to $59 \mathrm{~cm} ; 80 \%$ black (7.5YR 2/1), and $10 \%$ dark brown (7.5YR 3/3), and $10 \%$ brown $(7.5 \mathrm{YR} 4 / 3)$, very channery loamy coarse sand and very channery fine sandy loam; common fine and medium distinct strong brown (7.5YR 5/6) redox concentrations on ped surfaces and common fine prominent grayish brown (10YR 5/2) redox depletions between peds; weak medium subangular blocky structure; very friable; $30 \%$ subrounded sandstone-shale gravel and 30\% subangular sandstone-shale channers; clear wavy boundary. Some question as to whether the EB horizon has redoximorphic features, not just mix of E and B materials. 96P0839

C-59 to $80 \mathrm{~cm}$; light olive brown $(2.5 \mathrm{Y} 5 / 3)$, very channery sandy loam; common fine distinct strong brown (7.5YR 5/8) redox concentrations on ped surfaces, few fine prominent dark reddish brown (5YR 3/4) redox concentrations around stones, and common fine distinct grayish brown (10YR 5/2) redox depletions on ped surfaces; massive; friable; $20 \%$ subrounded sandstone-shale gravel and 30\% subangular sandstoneshale channers; abrupt broken boundary. 96P0840 
$\mathrm{R}-80 \mathrm{~cm}$.

\section{Soil Series: MWD Gauley}

\section{Site Identification \#: 95 WV093002}

Date Sampled: 8/1/1995

Map Unit Symbol: $140 \mathrm{C}$

Lab Pedon \#: 95P0853 Source Lab Id: NSSL

MLRA: 127

County Name: Tucker

Soil Survey Area Name: Tucker High Elevation Study

Location Description: $46 \mathrm{~m}$ north of USFS road 13 about $4.02 \mathrm{~km}$ west of US219 east of Davis. About $91 \mathrm{~m}$ west of a gas well clearing.

Quadrangle Name: Blackwater Falls

Latitude: 39 degrees 5 minutes 16.3 seconds $\mathrm{N}$

Longitude: 79 degrees 27 minutes 21.1 seconds W

Photograph \#: 3222-149

Slope Characteristics Information

Slope: $4 \%$

Horizontal Shape: linear

Vertical Shape: Concave

Total Slope Length: $20 \mathrm{~m}$

Slope Length Above Site: $80 \mathrm{~m}$

Elevation: $1121 \mathrm{~m}$

Physiography:

Local: Plateau

Major: Mountains

Runoff: Medium

Classification: coarse-loamy, siliceous, frigid Typic Epiaquods

Moisture Regime: Udic moisture regime

Landuse: Forest land not grazed

Stoniness: $10 \%$

Permeability: Moderate

Natural Drainage Class: Moderately well drained

Parent material: Residuum from sandstone-shale

Vegetative information: Red spruce, hemlock, yellow birch, red maple.

Particle Size Control Section: 25 to $90 \mathrm{~cm}$

Diagnostic Features: ochric, 0 to $10 \mathrm{~cm}$

albic, 10 to $18 \mathrm{~cm}$

spodic, 18 to $34 \mathrm{~cm}$

placic, 34 to $41 \mathrm{~cm}$, in portions of the pedon

spodic, 41 to $58 \mathrm{~cm}$

Current series classification: none, anticipated as Aquic Haplorthods 
Pedon classification (Soil Survey Staff, 1998; 1999): coarse-loamy, siliceous, superactive, frigid Typic Epiaquod

Described by: Sencindiver, Jenkins

Notes: Canaan Mtn site, see site notes for 093003. Mapped on CIR (from

FO), referenced to ASCS flight for consistency.

Oi1--2 to $0 \mathrm{~cm}$. Rock transect $=30 \% .95 \mathrm{P} 5388$

Oi2--0 to $3 \mathrm{~cm}$; many fine and medium roots throughout. 95P5389

Oe--3 to $5 \mathrm{~cm}$; many fine to coarse roots throughout. Horizon split for sampling due to charcoal in a portion of pit. $95 \mathrm{P} 5390$

A--5 to $10 \mathrm{~cm} ; 20 \%$ black (10YR $2 / 1)$, and $80 \%$ very dark gray (10YR 3/1), mucky sandy loam; weak fine granular structure; very friable; many very fine to coarse roots throughout; 5\% subangular sandstone channers; abrupt wavy boundary. 95P5392

E--10 to $18 \mathrm{~cm}$; brown (7.5YR 5/2), loamy sand and sandy loam; weak coarse subangular blocky structure parting to single grain; friable; common very fine to coarse roots between peds; 5\% subangular sandstone channers; abrupt wavy boundary. 95P5393

Bh--18 to $27 \mathrm{~cm}$; dark brown (7.5YR 3/2), loamy sand; weak fine and medium subangular blocky structure; very friable; common very fine to medium roots throughout; $5 \%$ subangular sandstone channers; clear wavy boundary. 95P5394

Bhs--27 to $34 \mathrm{~cm} ; 50 \%$ dark reddish brown (5YR 3/3), and $50 \%$ brown (7.5YR 4/4), loamy coarse sand; weak medium subangular blocky structure; very friable; few fine and medium roots between peds; $5 \%$ subangular sandstone channers; clear broken boundary. 95P5395

Bsm/Bs--34 to $41 \mathrm{~cm} ; 30 \%$ dark reddish brown (2.5YR 2/4), broken face, and $30 \%$ dark red (2.5YR 3/6), and 30\% brown (7.5YR 4/4), and 10\% strong brown (7.5YR 5/6), sandy loam; few fine distinct grayish brown (10YR 5/2) redox depletions at top of horizon and few fine distinct dark yellowish brown (10YR 4/6) redox concentrations throughout; weak medium subangular blocky structure; extremely firm, strongly cemented by iron, strong, brittle; few roots; $10 \%$ subangular sandstone channers; abrupt irregular boundary. Placic horizon dips across pit face, in this region (Canaan Mtn) it appears somewhat common. Note that it interplays with horizon exhibiting both Bs and Bw characteristics. The placic firmness and brittleness are described here, although surrounding materials are friable. 95P5396

Bs--41 to $58 \mathrm{~cm}$; 70\% brown (7.5YR 5/4), and 30\% dark reddish brown (5YR 3/3), channery loamy sand; weak coarse subangular blocky structure; friable; $25 \%$ subangular sandstone channers; clear wavy boundary. 95P5397 
C--58 to $90 \mathrm{~cm}$; light yellowish brown (10YR 6/4), channery sandy loam; common fine distinct light brownish gray $(2.5 \mathrm{Y} 6 / 2)$ redox depletions throughout and common fine distinct strong brown (7.5YR 5/8) redox concentrations throughout; massive; firm; $15 \%$ subangular sandstone channers; abrupt smooth boundary. 95P5398

$\mathrm{R}-90 \mathrm{~cm}$.

\section{Soil Series: MWD Gauley \\ Site Identification \#: 95WV093003}

Date Sampled: 8/1/1995

Map Unit Symbol: 140C

Lab Pedon \#: 95P0854 Source Lab Id: NSSL

MLRA: 127

County Name: Tucker

Soil Survey Area Name: Tucker High Elevation Study

Location Description: About 61 m north of USFS road 13, about $456 \mathrm{~m}$ west of pedon 093002 .

Quadrangle Name: Blackwater Falls

Latitude: 39 degrees 5 minutes 0.4 seconds $\mathrm{N}$

Longitude: 79 degrees 27 minutes 40 seconds $\mathrm{W}$

Photograph \#: 3222-149*

Slope Characteristics Information

Slope: $1 \%$

Horizontal Shape: linear

Vertical Shape: linear

Total Slope Length: $60 \mathrm{~m}$

Slope Length Above Site: $60 \mathrm{~m}$

Elevation: $1121 \mathrm{~m}$

Physiography:

Local: Plateau

Major: Mountains

Microrelief:

Kind: tree throw feature

Elevation: $20 \mathrm{~cm}$

Runoff: Low

Moisture Regime: Udic

Landuse: Forest land not grazed

Stoniness: $15 \%$

Permeability: Moderate

Natural Drainage Class: Moderately well drained

Parent Material and/or Bedrock Information

Parent material: Slightly weathered residuum from sandstone-shale

Vegetative information: Red spruce, hemlock, some Norway spruce (Picea ??) 
Particle Size Control Section: 25 to $83 \mathrm{~cm}$

Diagnostic Features: ochric, 0 to $11 \mathrm{~cm}$

albic, 11 to $24 \mathrm{~cm}$

spodic, 24 to $29 \mathrm{~cm}$

placic, 29 to $31 \mathrm{~cm}$, inconsistently expressed

cambic, 31 to $52 \mathrm{~cm}$

Current series classification: none, anticipated as Aquic Haplorthods

Pedon classification (Soil Survey Staff, 1998; 1999): coarse-loamy, siliceous, superactive, frigid Typic Epiaquod

Described by: Sencindiver, Jenkins.

Notes: Canaan Mtn., these soils mapped as the normal mod well drained

Gauley, but have less fragments and are sometimes placic. Mapped on

CIR photography from Elkins FO, NRCS, but referenced on ASCS

flight.

Oi1--2 to $0 \mathrm{~cm}$; strong brown (7.5YR 5/6). Rock transect $=10 \%$. 95P5399

Oi2--0 to $4 \mathrm{~cm}$; common fine to coarse roots throughout. 95P5400

Oe--4 to $7 \mathrm{~cm}$; many very fine to coarse roots throughout. 95P5401

Oa--7 to $9 \mathrm{~cm}$; black (N 2/0), sapric material; many very fine to coarse roots throughout. 95P5402

A--9 to $11 \mathrm{~cm}$; $90 \%$ black (10YR 2/1), and 10\% very dark gray (10YR 3/1), mucky sandy loam and very channery; weak medium granular structure; very friable; many fine to coarse roots throughout; $35 \%$ subangular sandstone channers and $15 \%$ subangular sandstone flagstones; abrupt wavy boundary. 95P5403

E--11 to $24 \mathrm{~cm} ; 80 \%$ grayish brown (10YR 5/2), and 20\% light brownish gray (10YR $6 / 2$ ), very

channery sandy loam; weak fine and medium subangular blocky structure; very friable; common fine to coarse roots throughout; $35 \%$ subangular sandstone channers and $15 \%$ subangular sandstone flagstones; clear wavy boundary. 95P5404

Bh--24 to $29 \mathrm{~cm}$; $95 \%$ dark brown (7.5YR 3/2), and 5\% black (7.5YR 2/1), channery sandy loam; few medium distinct grayish brown (10YR 5/2) moist, few medium distinct brown (10YR 5/3) moist, and few fine distinct dark grayish brown (10YR 4/2) redox depletions; weak fine and medium granular structure; friable; common fine and medium roots between peds; $15 \%$ subangular sandstone channers; abrupt wavy boundary. 95P5405

Bsm--29 to $31 \mathrm{~cm}$; 80\% dark reddish brown (5YR 3/3), broken face, and 10\% dark reddish brown (5YR 3/2), and 10\% yellowish red (5YR 5/6); few fine distinct dark 
grayish brown (10YR 4/2) redox depletions; very firm, some cementation by iron, brittle; few roots; clear wavy boundary.

Placic material present, but not sampled: swirly, somewhat inconsistent across pit, but occurring in about $50 \%$.

Bw--31 to $43 \mathrm{~cm}$; yellowish brown (7.5YR 5/6), sandy loam; few fine distinct dark gray (10YR

4/1) moist and few fine distinct brown (10YR 5/3) redox depletions; weak medium subangular blocky structure; very friable; few fine roots between peds; $10 \%$ subangular sandstone channers; clear wavy boundary. 95P5406

BC--43 to $52 \mathrm{~cm}$; $70 \%$ light olive brown (2.5Y 5/4), broken face, and 30\% yellowish brown (10YR 5/6), sandy loam; weak medium subangular blocky structure; very friable; few faint discontinuous light olive brown (2.5Y 5/3) silt coatings on faces of peds and in pores; $10 \%$ subangular sandstone channers; gradual wavy boundary.95P 5407

C--52 to $83 \mathrm{~cm}$; light olive brown (2.5Y 5/3), sandy loam; massive; friable; $10 \%$ subangular sandstone channers; clear wavy boundary. 95P5408

$\mathrm{Cr}--83 \mathrm{~cm}$. 


\section{Soil Series: Mandy}

\section{Site Identification \#: $95 \mathrm{WV083005}$}

Map Unit Name: Snowdog-Mandy complex, 35-55\% slopes, extremely stony.

Date Sampled: 8/29/1995

Map Unit Symbol: $142 \mathrm{~F}$

Lab Pedon \#: 96P0082 Source Lab Id: NSSL

MLRA: 127

County Name: Randolph

Soil Survey Area Name: Randolph High Elevation Study

Location Description: About 106 m north-northeast of pedon 083008.

Quadrangle Name: Bowden

Latitude: 38 degrees 59 minutes 2 seconds $\mathrm{N}$

Longitude: 79 degrees 41 minutes 45 seconds W

Photograph \#: 3222-79

Slope Characteristics Information

Slope: $49 \%$

Aspect: 352 degrees

Horizontal Shape: linear

Vertical Shape: Convex

Total Slope Length: $150 \mathrm{~m}$

Slope Length Above Site: $60 \mathrm{~m}$

Elevation: $1155 \mathrm{~m}$

Physiography:

Local: Mountain Slope

Major: Mountains

Geomorphic Position: on upper third, back slope, of a side slope

Runoff: Very high

Moisture Regime: Udic moisture regime

Landuse: Forest land not grazed

Permeability: Moderately rapid

Natural Drainage Class: Well drained

Parent material: Residuum from siltstone.

Vegetative Information: Yellow birch, Black cherry, Red spruce, Red maple, Am. beech

Particle Size Control Section: 25 to $97 \mathrm{~cm}$

Diagnostic Features: ochric, 0 to $25 \mathrm{~cm}$ cambic, 25 to $79 \mathrm{~cm}$

Current series classification: loamy-skeletal, mixed, frigid Typic Dystrochrepts

Pedon classification (Soil Survey Staff, 1998; 1999): loamy-skeletal, siliceous, active, frigid Typic Dystrudrept

Described by: Jenkins

Oil -1 to $0 \mathrm{~cm}$; few roots. Rock transect $=26.5 \% .96 \mathrm{P} 0824$

Oi2 - 0 to $2 \mathrm{~cm}$; common very fine to medium roots throughout. $96 \mathrm{P} 0825$ 
Oe-2 to $4 \mathrm{~cm}$; many very fine to coarse roots throughout; clear wavy boundary. 96P0826

A -4 to $13 \mathrm{~cm} ; 60 \%$ very dark gray (10YR $3 / 1)$, broken face, and $40 \%$ very dark grayish brown (10YR 3/2), very channery silt loam; moderate fine subangular blocky structure; very friable; many very fine to coarse roots throughout; $10 \%$ subangular sandstone-siltstone gravel and 20\% subangular sandstone-siltstone channers and 5\% subangular sandstone-siltstone flagstones; clear wavy boundary. 96P0827

BA-13 to $25 \mathrm{~cm} ; 80 \%$ brown (10YR 4/3), and $20 \%$ dark yellowish brown (10YR 4/6), channery silt loam; weak fine and medium subangular blocky structure; friable; many fine to coarse roots throughout; $10 \%$ subangular sandstone-siltstone gravel and $20 \%$ subangular sandstone-siltstone channers; clear wavy boundary. 96P0828

Bw1-25 to $46 \mathrm{~cm}$; yellowish brown (10YR 5/6), very channery silt loam; weak fine and medium subangular blocky structure; friable; common fine and medium roots between peds; $10 \%$ subangular sandstone-siltstone gravel and $25 \%$ subangular sandstone-siltstone channers and 5\% subangular sandstone-siltstone flagstones; gradual wavy boundary. 96P0829

Bw2 - 46 to $79 \mathrm{~cm}$; olive brown (2.5Y 4/4), very channery loam; weak medium subangular blocky structure; friable; common fine roots between peds; $15 \%$ subangular sandstone-siltstone gravel and 35\% subangular sandstone-siltstone channers and 5\% subangular sandstone-siltstone flagstones; gradual wavy boundary. 96P0830

C-79 to $97 \mathrm{~cm} ; 60 \%$ olive brown (2.5Y 4/4), broken face, and $40 \%$ dark yellowish brown (10YR 4/6), extremely channery loam; massive; friable; $20 \%$ subangular sandstone-siltstone gravel and 45\% subangular sandstone-siltstone channers and 15\% subangular sandstone-siltstone flagstones; clear wavy boundary. 96P0831

$\mathrm{Cr}-97 \mathrm{~cm}$.

\section{Soil Series: Mandy}

\section{Site Identification \#: 95WV083007}

Map Unit Name: Snowdog-Mandy complex, 35-55\% slopes, extremely stony. Map Unit Symbol: 142F

Date Sampled: 9/20/1995

Lab Pedon \#: 96P0084 Source Lab Id: NSSL

MLRA: 127

County Name: Randolph

Soil Survey Area Name: Randolph High Elevation Study

Location Description: About $1.13 \mathrm{~km}$ north of USFS road 91, going out the Little Black Fork Trail, about $.81 \mathrm{~km}$ east of Stuart Knob and about $3.54 \mathrm{~km}$ 
northwest of Bear Heaven Recreation Area and

Campground.

Quadrangle Name: Bowden

Latitude: 38 degrees 56 minutes 47 seconds $\mathrm{N}$

Longitude: 79 degrees 42 minutes 11 seconds W

Photograph \#: 3222-56

Slope Characteristics Information

Slope: $37 \%$

Aspect: 266 degrees

Horizontal Shape: Convex

Vertical Shape: linear

Total Slope Length: $90 \mathrm{~m}$

Slope Length Above Site: $50 \mathrm{~m}$

Elevation: $1120 \mathrm{~m}$

Physiography:

Local: Mountain Slope

Major: Mountains

Geomorphic Position: on upper third, back slope, of a side slope

Runoff: Very high

Moisture Regime: Udic

Landuse: Forest land not grazed

Permeability: Moderately rapid

Natural Drainage Class: Well drained

Parent material: Residuum from sandstone-siltstone

Vegetative Information: Black cherry, Red spruce, C. hemlock, Red oak, Red maple, Am. Beech.

Particle Size Control Section: 25 to $100 \mathrm{~cm}$

Diagnostic Features: ochric, 0 to $18 \mathrm{~cm}$

cambic, 18 to $63 \mathrm{~cm}$

Current series classification: loamy-skeletal, mixed, frigid Typic Dystrochrepts

Pedon classification (Soil Survey Staff, 1998; 1999): loamy-skeletal, siliceous, active,

frigid Typic Dystrudept

Described by: Jenkins, Gorman

Notes: Very diverse vegetation in overstory.

Oi1 -1 to $0 \mathrm{~cm}$. Rock transect $=72.5 \% .96 \mathrm{P} 0841$

Oi2--0 to $3 \mathrm{~cm}$; flaggy fibric material; common very fine and fine roots throughout; $10 \%$ subangular sandstone-siltstone channers and $20 \%$ subangular sandstone-siltstone flagstones; clear wavy boundary. 96P0842

Oe-3 to $6 \mathrm{~cm}$; flaggy hemic material; many fine and medium roots throughout; $10 \%$ subangular sandstone-siltstone channers and $20 \%$ subangular sandstone-siltstone flagstones; clear wavy boundary. 96P0843 
A-6 to $18 \mathrm{~cm} ; 50 \%$ black (10YR $2 / 1)$, and $50 \%$ very dark gray (10YR 3/1), very channery silt loam; moderate fine and medium subangular blocky structure; very friable; many very fine to coarse roots throughout; $20 \%$ subangular sandstone-siltstone channers and $20 \%$ subangular sandstone-siltstone flagstones; clear wavy boundary. 96P0844

Bw-18 to $63 \mathrm{~cm}$; 95\% dark yellowish brown (10YR 4/6), broken face, and 5\% brown (10YR 4/3), very channery loam; weak fine and medium subangular blocky structure; friable; common very fine to coarse roots throughout; $5 \%$ subangular sandstone-siltstone gravel and $15 \%$ subangular sandstone-siltstone channers and $30 \%$ subangular sandstonesiltstone flagstones; gradual wavy boundary.

96P0845

BC-63 to $91 \mathrm{~cm}$; dark yellowish brown (10YR 4/6), extremely channery loam; weak fine subangular blocky structure; friable; few very fine and fine roots between peds; $20 \%$ subangular sandstone-siltstone gravel and 30\% subangular sandstone-siltstone channers and 20\% subangular sandstone-siltstone flagstones; abrupt broken boundary. 96P0846

$\mathrm{R}-91 \mathrm{~cm}$.

\section{Soil Series: Mandy}

\section{Site Identification \#: 95WV093004}

Map Unit Name: Snowdog-Mandy complex, 35-55\% slopes, extremely stony.

Date Sampled: 8/31/1995

Map Unit Symbol: 142F

Lab Pedon \#: 96P0086 Source Lab Id: NSSL

MLRA: 127

County Name: Tucker

Soil Survey Area Name: Tucker High Elevation Study

Location Description: North sideslope of Weiss Knob, about $.65 \mathrm{~km}$ south of Canaan ski resort.

Quadrangle Name: Laneville

Latitude: 38 degrees 59 minutes 41 seconds $\mathrm{N}$

Longitude: 79 degrees 25 minutes 42 seconds W

Photograph \#: 3216-99

Slope Characteristics Information

Slope: $36 \%$

Aspect: 22 degrees

Horizontal Shape: Convex

Vertical Shape: linear

Total Slope Length: $70 \mathrm{~m}$

Slope Length Above Site: $30 \mathrm{~m}$ 
Elevation: $1318 \mathrm{~m}$

Physiography:

Local: Mountain Slope

Major: Mountains

Geomorphic Position: on upper third, back slope, of a side slope

Runoff: Very high

Moisture Regime: Udic

Landuse: Forest land not grazed

Permeability: Moderate

Natural Drainage Class: Well drained

Parent Material and/or Bedrock Information

Parent material: Residuum from siltstone-sandstone shale.

Vegetative Information: Yellow birch, red maple, red spruce, hemlock.

Particle Size Control Section: 25 to $100 \mathrm{~cm}$

Diagnostic Features: ochric, 0 to $15 \mathrm{~cm}$

cambic, 15 to $88 \mathrm{~cm}$

Current series classification: loamy-skeletal, mixed, frigid Typic Dystrochrepts

Pedon classification (Soil Survey Staff, 1998; 1999): loamy-skeletal, siliceous, superactive, frigid Andic Dystrudept

Described by: Jenkins

Oi1 -2 to $0 \mathrm{~cm}$. Surface horizon rock transects $=15 \% .96 \mathrm{P} 0856$

Oi2--0 to $3 \mathrm{~cm} .96 \mathrm{P} 0857$

Oe-3 to $5 \mathrm{~cm}$; many very fine to coarse roots throughout; $10 \%$ subangular sandstonesiltstone gravel and $15 \%$ subangular sandstone-siltstone channers and $5 \%$ subangular sandstone-siltstone flagstones; clear wavy boundary. 96P0858

A-5 to $15 \mathrm{~cm} ; 90 \%$ very dark grayish brown (10YR 3/2), broken face, and $10 \%$ brown (10YR 4/3), very channery silt loam; weak fine and medium subangular blocky structure; very friable; common very fine to coarse roots throughout; $10 \%$ subangular sandstonesiltstone gravel and 15\% subangular sandstone-siltstone channers and 5\% subangular sandstone-siltstone flagstones; clear wavy boundary. 96P0859

Bw-15 to $51 \mathrm{~cm}$; yellowish brown (10YR 5/6), very channery silt loam; weak fine and medium subangular blocky structure; friable; common fine to coarse roots between peds; $20 \%$

subangular sandstone-siltstone gravel and 15\% subangular sandstone-siltstone channers; gradual wavy boundary. 96P0860

BC-51 to $88 \mathrm{~cm} ; 50 \%$ dark yellowish brown (10YR 4/4), broken face, and $50 \%$ yellowish brown (10YR 5/4), very channery silt loam; weak fine and medium subangular blocky structure; friable; few fine and medium roots between peds; $30 \%$ subangular sandstone-siltstone gravel and 25\% subangular sandstone-siltstone channers and 5\% subangular sandstone-siltstone flagstones; gradual wavy boundary. 96P0861 
2C-88 to $108 \mathrm{~cm} ; 70 \%$ dark yellowish brown (10YR 4/4), broken face, and 30\% yellowish brown (10YR 5/4), extremely channery fine sandy loam; massive; friable; few fine roots matted around stones; $30 \%$ subangular sandstone-siltstone gravel and $40 \%$ subangular sandstone-siltstone channers and 5\% subangular sandstone-siltstone flagstones; clear wavy boundary.

FSL texture is outside the range for the series, but sampled as a minor variation from siltstone to fine-grained sandstone shale bedrock effects on the substratum. 96P0862

$2 \mathrm{Cr}-108 \mathrm{~cm} ; 85 \%$ subangular sandstone-siltstone.

\section{Soil Series: Mandy}

\section{Site Identification \#: 95WV093005}

Map Unit Name: Snowdog-Mandy complex, 35 to $55 \%$ slopes, extremely stony

Date Sampled: 9/11/1995

Map Unit Symbol: $142 \mathrm{~F}$

Lab Pedon \#: 96P0087 Source Lab Id: NSSL

MLRA: 127

County Name: Tucker

Soil Survey Area Name: Tucker High Elevation

Location Description: South slope of Weiss Knob, about $1.13 \mathrm{~km}$ south of Canaan Ski Resort.

Quadrangle Name: Laneville

Latitude: 38 degrees 59 minutes 31 seconds $\mathrm{N}$

Longitude: 79 degrees 25 minutes 46 seconds W

Photograph \#: 3216-99

Slope Characteristics Information

Slope: $35 \%$

Aspect: 175 degrees

Horizontal Shape: linear

Vertical Shape: Convex

Total Slope Length: $46 \mathrm{~m}$

Slope Length Above Site: $15 \mathrm{~m}$

Elevation: $1307 \mathrm{~m}$

Physiography: Local: Mountain Slope

Major: Mountains

Geomorphic Position: on a shoulder, of a side slope

Flooding Information

Ponding Information

Frequency: None

Frequency: None

Runoff: Very high

Moisture Regime: Udic

Landuse: Forest land not grazed 
Permeability: rapid over moderately rapid

Natural Drainage Class: Well drained

Parent material: Residuum from shale-siltstone, with a dip of about 30 degrees.

Bedrock information:

Kind: shale-siltstone

Vegetative Information: Yellow birch, red maple, black cherry, red spruce.

Particle Size Control Section: 25 to $100 \mathrm{~cm}$

Diagnostic Features: ochric, 0 to $24 \mathrm{~cm}$

cambic, 24 to $67 \mathrm{~cm}$

Current series classification: loamy-skeletal, mixed, frigid Typic Dystrochrepts

Pedon classification (Soil Survey Staff, 1998; 1999): loamy-skeletal, siliceous, active, frigid Typic Dystrudrept

Described by: Jenkins, Jim Gorman (WVU)

Notes: $\mathrm{Cr}$ horizon tilted, pickable loose shale. $\mathrm{L}$ horizon $=2 \mathrm{~cm}$. Texture of the fines in lower horizon is silty, but very small shale fragments may give loam or coarser lab texture after sieving (if so use field call). Some sandstone fragments in horizons 2 through 4. Some lithochromic reds and browns in lower horizons.

Oi1 -2 to $0 \mathrm{~cm}$; Rock transects $62 \% .96 \mathrm{P} 0863$

Oi2--0 to $3 \mathrm{~cm}$. 96P0864

Oe- -3 to $5 \mathrm{~cm}$; common fine and medium roots throughout. 96P0865

A-5 to $11 \mathrm{~cm}$; very dark grayish brown (10YR $3 / 2)$, very channery silt loam; moderate fine subangular blocky structure; very friable; common very fine to coarse roots throughout; $5 \%$ subangular shale-siltstone 20 to $75 \mathrm{~mm}$ fragments and $20 \%$ subangular sandstone-siltstone channers and $10 \%$ subangular sandstone-siltstone flagstones; clear wavy boundary. 96P0866

BA-11 to $24 \mathrm{~cm}$; brown (10YR 4/3), very channery silt loam; weak medium subangular blocky structure; friable; common very fine to coarse roots throughout; $5 \%$ subangular shale-siltstone 20 to $75 \mathrm{~mm}$ fragments and $5 \%$ subangular sandstone-siltstone gravel and $10 \%$ subangular sandstone-siltstone channers and $10 \%$ subangular sandstone-siltstone flagstones; clear wavy boundary. 96P0867

$\mathrm{Bw}-24$ to $46 \mathrm{~cm}$; $95 \%$ yellowish brown (10YR 5/6), and 5\% brown (10YR 4/3), channery silt loam; weak medium subangular blocky structure; friable; common fine and medium roots throughout; $15 \%$ subangular shale-siltstone 20 to $75 \mathrm{~mm}$ fragments and $10 \%$ subangular shale-siltstone gravel and 5\% subangular shale-siltstone channers; clear wavy boundary. 96P0868

$\mathrm{BC}-46$ to $67 \mathrm{~cm}$; light olive brown (2.5Y 5/4), very gravelly loam; weak fine and medium subangular blocky structure; friable; common fine roots between peds; $20 \%$ subangular 
shale-siltstone 20 to $75 \mathrm{~mm}$ fragments and $10 \%$ subangular shale-siltstone gravel and $10 \%$ subangular shale-siltstone channers and $5 \%$ subangular shale-siltstone flagstones; clear wavy boundary. 96P0869

C—67 to $100 \mathrm{~cm}$; light olive brown (2.5Y 5/4), very channery loam; massive; friable; few fine roots matted around stones; $30 \%$ subangular shale-siltstone 20 to $75 \mathrm{~mm}$ fragments and $20 \%$ subangular shale-siltstone gravel and $20 \%$ subangular shale-siltstone channers and $10 \%$ subangular shale-siltstone flagstones; clear broken boundary. 96P0870

$\mathrm{Cr}-100 \mathrm{~cm} ; 90 \%$ angular shale-siltstone. Fractured shale bedrock with pockets of soil material. 


\section{Soil Series: Snowdog}

\section{Site Identification \#: 95WV083001}

Date Sampled: 8/2/1995

Map Unit Symbol: 46E

Lab Pedon \#: 95P0855 Source Lab Id: NSSL

MLRA: 127

County Name: Randolph

Soil Survey Area Name: Tucker High Elevation

Location Description: About $152 \mathrm{~m}$ west of USFS road 324 about $3.22 \mathrm{~km}$ north of the Yellow Crk. entrance to

Otter Cr. Wilderness.

Quadrangle Name: Bowden

Latitude: 38 degrees 58 minutes 47.1 seconds $\mathrm{N}$

Longitude: 79 degrees 41 minutes 46.8 seconds W

Photograph \#: 3222-79

Slope Characteristics Information

Slope: $17 \%$

Aspect: 259 degrees

Horizontal Shape: convex

Vertical Shape: linear

Total Slope Length: $100 \mathrm{~m}$

Slope Length Above Site: $50 \mathrm{~m}$

Elevation: $1119 \mathrm{~m}$

Physiography:

Local: Mountain Slope

Major: Mountains

Geomorphic Position: high foot slope, of a mountain side slope

Microrelief:

Kind: tree throw feature

Elevation: $10 \mathrm{~cm}$

Runoff: High

Moisture Regime: Udic

Landuse: Forest land not grazed

Stoniness: $15 \%$

Permeability: Slow

Natural Drainage Class: Moderately well drained

Parent material: Residuum from shale-siltstone

Vegetative Information: Black cherry, Red spruce, Yellow birch, Red maple

Particle Size Control Section: 25 to $100 \mathrm{~cm}$

Diagnostic Features: ochric, 0 to $24 \mathrm{~cm}$

cambic, 24 to $42 \mathrm{~cm}$

fragipan, 42 to $105 \mathrm{~cm}$

Current series classification: fine-loamy, mixed, frigid Aquic Fragiochrepts

Pedon classification (Soil Survey Staff, 1998; 1999): fine-loamy, siliceous, active, frigid Typic Fragiudept 
Described by: J.C. Sencindiver, Roy Pyle, A.B. Jenkins.

Oi1--2 to $0 \mathrm{~cm}$. Rock transect $=57.5 \%$. 95P5409

Oi2--0 to $3 \mathrm{~cm}$. 95P5410

Oa--3 to $9 \mathrm{~cm}$; black (N 2/0), sapric material; many fine to coarse roots throughout; clear wavy boundary. 95P5411

A--9 to $13 \mathrm{~cm}$; black (10YR 2/1), channery loam; moderate fine and medium granular structure; very friable; many fine to coarse roots throughout; $30 \%$ subangular sandstoneshale channers; clear wavy boundary. 95P5412

AB--13 to $24 \mathrm{~cm}$; dark brown (10YR 3/3), channery silt loam; weak fine subangular blocky structure parting to weak medium granular; very friable; many fine to coarse roots throughout; 30\% subangular sandstone-shale channers; clear broken boundary. 95P5413

Bw--24 to $42 \mathrm{~cm}$; dark yellowish brown (10YR 4/4), channery loam; weak fine and medium subangular blocky structure; friable; common fine to coarse roots throughout; $30 \%$ subangular sandstone-shale channers; clear wavy boundary. 95P5414

Bx 1--42 to $65 \mathrm{~cm}$; $80 \%$ yellowish brown (10YR 5/6), and 20\% strong brown (7.5YR $5 / 8$ ), sandy loam; many coarse distinct gray (10YR 6/1) redox depletions on ped surfaces and few medium and coarse distinct yellowish red (5YR 5/8) redox concentrations throughout; weak very coarse prismatic structure; firm, W by silica, brittle; common fine and medium roots between peds; $10 \%$ subangular sandstoneshale channers; clear wavy boundary. Roots along prism faces. 95P5415

Bx2--65 to $105 \mathrm{~cm} ; 50 \%$ brown (10YR 4/3), and 50\% brown (10YR 5/3), channery sandy loam; few coarse prominent yellowish red (5YR 5/8) redox concentrations throughout, few coarse faint brown (10YR 5/3) redox depletions on ped surfaces, and few coarse distinct grayish brown (10YR 5/2) redox depletions on ped surfaces; weak very coarse prismatic structure; firm, brittle; few roots; $5 \%$ subangular sandstone-shale gravel and $20 \%$ subangular sandstone-shale channers; clear wavy boundary. 95P5416

2C1--105 to $121 \mathrm{~cm} ; 60 \%$ dark yellowish brown (10YR 4/4), and 40\% dark grayish brown (10YR 4/2), channery silty clay loam; common medium distinct yellowish brown (10YR 5/6) redox concentrations; massive; firm; few roots; $5 \%$ subangular sandstoneshale gravel and $25 \%$ subangular sandstone-shale channers; clear wavy boundary. 95P5417

2C2--121 to $148 \mathrm{~cm}$; very dark gray (10YR 3/1), silty clay loam; few fine and medium distinct strong brown (7.5YR 5/8) moist and few coarse distinct yellowish brown (10YR 5/6) redox concentrations; massive; firm; few roots; $10 \%$ subangular sandstone-shale channers; clear wavy boundary. 95P5418 
2C3--148 to $159 \mathrm{~cm} ; 50 \%$ yellowish brown (10YR 5/6), and 50\% pale brown (10YR $6 / 3$ ), silty clay; massive; firm; few roots; $10 \%$ subangular sandstone-shale channers; clear wavy boundary. 95P5419

2C4--159 to $205 \mathrm{~cm}$; $70 \%$ grayish brown (10YR 5/2), and 30\% yellowish brown (10YR $5 / 6$ ), very channery silty clay loam; massive; firm; few roots; $15 \%$ subangular sandstoneshale gravel and $30 \%$ subangular sandstone-shale channers; clear wavy boundary. This horizon was originally split in two breaking at $185 \mathrm{~cm}$ based on an increase in channers. 95P5420

\section{Soil Series: Snowdog}

\section{Site Identification \#: 95WV083004}

Map Unit Name: Snowdog very channery loam, $15-35 \%$ slopes, rubbly.

Date Sampled: 8/28/1995

Map Unit Symbol: 46E

Lab Pedon \#: 96P0081 Source Lab Id: SSL

MLRA: 127

County Name: Randolph

Soil Survey Area Name: Tucker High Elevation Study

Location Description: About 91 m north of USFS road 19 to Dolly

Sods, about $4.83 \mathrm{~km}$ east of Laneville and about

$1.45 \mathrm{~km}$ west of the Tucker County line.

Quadrangle Name: Hopeville

Latitude: 38 degrees 57 minutes 4 seconds $\mathrm{N}$

Longitude: 79 degrees 22 minutes 9 seconds W

Photograph \#: 3216-100

Slope Characteristics Information

Slope: $27 \%$

Aspect: 186 degrees

Horizontal Shape: Convex

Vertical Shape: linear

Total Slope Length: $160 \mathrm{~m}$

Slope Length Above Site: $40 \mathrm{~m}$

Elevation: $1143 \mathrm{~m}$

Physiography:

Local: Mountain Slope

Major: Mountains

Geomorphic Position: back slope, of a side slope.

Microrelief:

Kind: tree throw feature

Elevation: $20 \mathrm{~cm}$

Runoff: High 
Moisture Regime: Udic moisture regime

Landuse: Forest land not grazed

Permeability: Very slow

Natural Drainage Class: Moderately well drained

Parent material: colluvium from sandstone-siltstone

Vegetative Information: Red oak, Black Cherry, Am. beech, Red maple

Particle Size Control Section: 25 to $100 \mathrm{~cm}$

Diagnostic Features: ochric, 0 to $17 \mathrm{~cm}$

cambic, 17 to $67 \mathrm{~cm}$

fragipan, 43 to $180 \mathrm{~cm}$

Current series classification: fine-loamy, mixed, frigid Aquic Fragiochrepts

Pedon classification (Soil Survey Staff, 1998; 1999): fine-loamy, siliceous, active, frigid

Typic Fragiudept

Described by: J. Sencindiver, A. Jenkins

Oil -2 to $0 \mathrm{~cm} ; 5 \%$ subangular sandstone-shale gravel and

$15 \%$ subangular sandstone-shale channers and $10 \%$

subangular sandstone-shale flagstones. Rock transects $=73 \% .96 \mathrm{P} 0815$

Oi2--0 to $4 \mathrm{~cm}$; many very fine to medium roots throughout; clear wavy boundary. $96 \mathrm{P} 0816$

A-4 to $9 \mathrm{~cm}$; very dark grayish brown (10YR 3/2), broken face, very channery silt loam; weak very fine and fine granular structure; very friable; many very fine to coarse roots throughout; 30\% subangular sandstone-shale channers and 5\% subangular sandstone-shale gravel; clear irregular boundary. 96P0817

AB-9 to $17 \mathrm{~cm}$; dark yellowish brown (10YR 3/4), channery silt loam; weak fine and medium granular structure; very friable; many very fine to coarse roots throughout; clear irregular boundary. 96P0818

Bw1-17 to $43 \mathrm{~cm}$; dark yellowish brown (10YR 4/6), broken face, channery silt loam; weak fine subangular blocky structure; friable; many fine to coarse roots throughout; $5 \%$ subangular sandstone-shale gravel and 15\% subangular sandstone-shale channers and 5\% subangular sandstone-shale flagstones; gradual wavy boundary. 96P0819

Bw2 - 43 to $67 \mathrm{~cm}$; dark yellowish brown (10YR 4/6), broken face, channery silt loam; moderate medium subangular blocky structure; friable; common fine to coarse roots throughout; 5\% subangular sandstone-shale gravel and 15\% subangular sandstone-shale channers and 5\% subangular sandstone-shale flagstones; clear wavy boundary. 96P0820

Bx1-67 to $85 \mathrm{~cm}$; yellowish brown (10YR 5/4), very channery sandy loam; common fine distinct very dark gray (10YR 3/1) redox depletions on ped surfaces, common fine and medium distinct grayish brown (10YR 5/2) redox depletions on ped surfaces, common fine and medium distinct strong brown (7.5YR 4/6) redox concentrations on ped 
surfaces, and few fine prominent yellowish red (5YR 5/6) redox concentrations on ped surfaces; weak very coarse prismatic structure; firm; few roots; very few distinct discontinuous manganese or iron-manganese stains; $15 \%$ subangular sandstone-shale gravel and $15 \%$ subangular sandstone-shale

channers and 10\% subangular sandstone-shale flagstones; clear wavy boundary. 96P0821

Bx2-85 to $180 \mathrm{~cm}$; dark yellowish brown (10YR 4/4), broken face, very channery sandy loam; common coarse distinct grayish brown (10YR 5/2) redox depletions on ped surfaces, few fine distinct very dark gray (10YR 3/1) redox depletions on ped surfaces, and common fine and medium distinct strong brown (7.5YR 4/6) redox concentrations on ped surfaces; moderate very coarse prismatic structure; very firm; common fine roots between peds; few distinct discontinuous manganese or iron-manganese stains; $20 \%$ subangular sandstone-shale gravel and 15\% subangular sandstone-shale channers and 5\% subangular sandstone-shale flagstones; clear wavy boundary. Few fine roots along prism faces. $96 \mathrm{P} 0822$

BC-180 to $203 \mathrm{~cm}$; dark yellowish brown (10YR 4/4), channery sandy loam; common coarse distinct gray (10YR 5/1) redox depletions on ped surfaces, common medium and coarse prominent yellowish red (5YR 5/6) redox concentrations on ped surfaces, and common medium distinct strong brown (7.5YR 4/6) redox concentrations on ped surfaces; weak medium subangular blocky structure;

friable; common fine roots between peds; 10\% subangular sandstone-shale gravel and $10 \%$ subangular sandstone-shale channers. Horizon extends below $203 \mathrm{~cm} .96 \mathrm{P} 0823$

\section{Soil Series: Snowdog Site Identification \#: 95 WV093006}

Map Unit Name: Snowdog very channery loam, 15-35\% slopes, rubbly.

Map Unit Symbol: 46E

Date Sampled: 9/11/1995

Lab Pedon \#: 96P0088 Source Lab Id: NSSL

Soil Survey Area \#: $093 \quad$ MLRA: 127

County Name: Tucker

Soil Survey Area Name: Tucker High Elevation Study

Location Description: North sideslope of Weiss Knob south of Canaan Ski Resort.

Quadrangle Name: Laneville

Latitude: 38 degrees 59 minutes 47 seconds N

Longitude: 79 degrees 25 minutes 38 seconds W

Photograph \#: 3216-99

Slope Characteristics Information

Slope: $17 \%$

Aspect: 8 degrees

Horizontal Shape: linear

Vertical Shape: Concave 
Total Slope Length: $200 \mathrm{~m}$

Slope Length Above Site: $50 \mathrm{~m}$

Elevation: $1283 \mathrm{~m}$

Physiography:

Local: Mountain Slope

Major: Mountains

Geomorphic Position: on lower third, back slope, of a side slope

Microrelief:

Kind: tree throw feature

Runoff: High

Moisture Regime: Udic

Landuse: Forest land not grazed

Natural Drainage Class: Moderately well drained

Parent material: local colluvium from sandstone-siltstone

Vegetative information: Yellow birch, red maple, black cherry, red spruce.

Particle Size Control Section: 25 to $100 \mathrm{~cm}$

Diagnostic Features: ochric, 0 to $24 \mathrm{~cm}$

cambic, 24 to $48 \mathrm{~cm}$

fragipan, 48 to $92 \mathrm{~cm}$

Current series classification: fine-loamy, mixed, frigid Aquic Fragiochrepts

Pedon classification (Soil Survey Staff, 1998; 1999): fine-loamy, siliceous, active, frigid Typic Fragiudept

Described by: J. Sencindiver, A. Jenkins

Notes: Mixed vegetation site.

Oi1-2 to $0 \mathrm{~cm}$; $5 \%$ subangular sandstone-shale gravel and $15 \%$ subangular sandstoneshale channers. Rock transects $=26.5 \% .96 \mathrm{P} 0871$

Oi2--0 to $2 \mathrm{~cm}$; many very fine to coarse roots throughout. $96 \mathrm{P} 0872$

Oe-2 to $4 \mathrm{~cm}$; many very fine to coarse roots throughout. $96 \mathrm{P} 0873$

A-4 to $16 \mathrm{~cm}$; very dark gray (10YR 3/1), channery silt loam; weak medium granular structure; very friable; many very fine to coarse roots throughout; $10 \%$ subangular sandstone-shale gravel and 20\% subangular sandstone-shale channers; clear wavy boundary. $96 \mathrm{P} 0874$

BA-16 to $24 \mathrm{~cm}$; brown (10YR 4/3), channery silt loam; weak fine and medium subangular blocky structure; very friable; many fine and medium roots throughout; $5 \%$ subangular sandstone-shale gravel and 15\% subangular sandstone-shale channers; clear wavy boundary. 96P0875

Bw1-24 to $36 \mathrm{~cm}$; yellowish brown (10YR 5/6), silt loam; weak fine and medium subangular blocky structure; friable; common fine and medium roots between peds; $5 \%$ subangular 
sandstone-shale gravel and 10\% subangular sandstone-shale channers; clear wavy boundary. 96P0876

Bw2-36 to $48 \mathrm{~cm}$; 80\% yellowish brown (10YR 5/4), broken face, and 20\% dark yellowish brown (10YR 4/4), broken face, loam; few fine and medium distinct grayish brown (10YR 5/2)

redox depletions on ped surfaces, few fine distinct brown $(7.5 \mathrm{YR} 4 / 4)$ redox concentrations throughout, and few fine distinct strong brown (7.5YR 5/8) redox concentrations throughout; weak fine and medium subangular blocky structure; friable; few fine roots between peds; 5\% subangular sandstone-shale gravel and 10\% subangular sandstone-shale channers; clear wavy boundary. 96P0877

$\mathrm{Bx}-48$ to $92 \mathrm{~cm}$; brown (10YR 5/3), channery sandy loam; common fine distinct grayish brown (10YR 5/2) redox depletions on ped surfaces, common medium distinct brown (7.5YR 4/4) redox concentrations and strong brown (7.5YR 5/8) redox concentrations throughout; weak very coarse prismatic structure parting to weak fine and medium platy; firm, $\mathrm{W}$, brittle; $15 \%$ subangular sandstone-shale gravel and 20\% subangular sandstone-shale channers; gradual wavy boundary.96P0878

BC-92 to $132 \mathrm{~cm} ; 50 \%$ yellowish brown (10YR 5/4), and 40\% dark yellowish brown (10YR 4/4), and 10\% yellowish brown (10YR 5/6), channery clay loam; common medium distinct grayish brown (10YR 5/2) redox depletions on ped surfaces, common medium distinct brown (7.5YR 4/4), and common medium distinct strong brown (7.5YR $5 / 8$ ) redox concentrations throughout; weak medium and coarse subangular blocky structure; firm; few faint discontinuous dark yellowish brown (10YR 4/4), moist, silt coats on faces of peds and in pores; $10 \%$ subangular sandstone-shale gravel and 30\% subangular sandstone-shale channers; gradual wavy boundary. 96P0879

2BC -132 to $200 \mathrm{~cm} ; 50 \%$ yellowish brown (10YR 5/4), and 50\% dark yellowish brown (10YR 4/4), very channery loam; few medium distinct grayish brown (10YR 5/2) redox depletions on ped surfaces, few medium distinct brown (7.5YR 4/4) redox concentrations throughout, and few medium distinct strong brown $(7.5 \mathrm{YR} 5 / 8)$ redox concentrations throughout; weak medium and coarse subangular blocky structure; firm; $5 \%$ subangular sandstone-shale gravel and 25\% subangular sandstone-shale channers and 15\% subangular sandstone-shale flagstones. Horizon extends below description depth. 96P0880

\section{Soil Series: Snowdog} Site Identification \#: $95 \mathrm{WV} 093008$

Map Unit Name: Snowdog very channery loam, 15-35\% slopes, rubbly. Date Sampled: 9/19/1995 
Map Unit Symbol: 46E

Lab Pedon \#: 96P0090 Source Lab Id: NSSL

MLRA: 127

County Name: Tucker

Soil Survey Area Name: Tucker High Elevation Study

Location Description: Little Stonecoal Run of Red Creek, in Dolly

Sods Wilderness Area.

Quadrangle Name: Laneville

Latitude: 38 degrees 59 minutes 32 seconds $\mathrm{N}$

Longitude: 79 degrees 23 minutes 55 seconds W

Photograph \#: 3216-99

Slope Characteristics Information

Slope: $22 \%$

Aspect: 358 degrees

Horizontal Shape: linear

Vertical Shape: Concave

Total Slope Length: $140 \mathrm{~m}$

Slope Length Above Site: $60 \mathrm{~m}$

Elevation: $1193 \mathrm{~m}$

Physiography:

Local: Hillside *

Major: Mountains

Geomorphic Position: back slope, of a side slope

Microrelief:

Kind: tree throw feature

Elevation: $25 \mathrm{~cm}$

Water Table Information

Water Table Depth: $40 \mathrm{~cm}$

Water Table Kind: Perched

Flooding Information Ponding Information

Frequency: None Frequency: None

Runoff: High

Moisture Regime: Udic

Landuse: Forest land not grazed

Permeability: Slow

Natural Drainage Class: Moderately well drained

Parent material: colluvium from sandstone-shale over residuum from shale-siltstone.

Vegetative information: Yellow birch, red maple, black cherry, red spruce.

Particle Size Control Section: 25 to $100 \mathrm{~cm}$

Diagnostic Features: ochric, 0 to $32 \mathrm{~cm}$

cambic, 32 to $55 \mathrm{~cm}$

fragipan, 55 to $100 \mathrm{~cm}$

Current series classification: fine-loamy, mixed, frigid Aquic Fragiochrepts

Pedon classification (Soil Survey Staff, 1998; 1999): fine-loamy, siliceous, active, frigid

Typic Fragiudept

Described by: A.Jenkins 
Notes: Good site, bedrock discovery unexpected, but within concept.

Oil -2 to $0 \mathrm{~cm}$. Rock transect $=21 \% .96 \mathrm{P} 0890$

Oi2--0 to $3 \mathrm{~cm}$; common very fine and fine roots throughout; clear wavy boundary. 96P0891

Oe-3 to $6 \mathrm{~cm}$; many fine and medium roots; clear wavy boundary. $96 \mathrm{P} 0892$

A-6 to $14 \mathrm{~cm} ; 80 \%$ very dark gray (10YR $3 / 1)$, and $20 \%$ black (10YR $2 / 1$ ), channery silt loam; weak medium granular structure; very friable; many very fine to coarse roots throughout; $5 \%$ subangular sandstone-shale gravel and $15 \%$ subangular sandstone-shale channers and $5 \%$ subangular sandstone-shale flagstones; clear wavy boundary. 96P0893

A/E - 14 to $32 \mathrm{~cm} ; 60 \%$ dark brown (7.5YR 3/2), 30\% brown (10YR 5/3), and $10 \%$ yellowish brown (10YR 5/6), channery silt loam; weak medium subangular blocky structure; friable; common very fine to medium roots throughout; $5 \%$ subangular sandstone-shale gravel and $15 \%$ subangular sandstone-shale channers and 5\% subangular sandstone-shale flagstones; clear wavy boundary. 96P0894

$\mathrm{Bw}-32$ to $55 \mathrm{~cm}$; yellowish brown (10YR 5/6), channery loam; few fine distinct grayish brown (10YR 5/2) redox depletions on ped surfaces, few fine distinct yellowish red (5YR $4 / 6)$, and common medium distinct strong brown (7.5YR 5/8) redox concentrations; weak medium subangular blocky structure; friable; common fine and medium roots between peds; $5 \%$ subangular sandstone-shale gravel and $15 \%$ subangular sandstone-shale channers; clear wavy boundary. 96P0895

$\mathrm{Bx}-55$ to $100 \mathrm{~cm}$; yellowish brown (10YR 5/4), channery sandy loam; few fine and medium distinct grayish brown (10YR 5/2) redox depletions on ped surfaces and few fine and medium distinct (7.5YR 5/6) redox concentrations; weak very coarse prismatic structure; very firm; few roots; $5 \%$ subangular sandstone-shale gravel and $15 \%$ subangular sandstone-shale channers and 10\% subangular sandstone-shale flagstones; abrupt wavy boundary. 96P0896

2BC-100 to $131 \mathrm{~cm} ; 60 \%$ dark yellowish brown (10YR 4/4), and 40\% yellowish brown (10YR 5/4), extremely channery sandy loam; weak fine and medium subangular blocky structure; friable; $25 \%$ subangular sandstone-siltstone gravel and $40 \%$ subangular sandstone-siltstone channers; gradual wavy boundary. 96P0897

$2 \mathrm{C}-131$ to $165 \mathrm{~cm} ; 60 \%$ dark yellowish brown (10YR 4/4), broken face, and 40\% yellowish brown (10YR 5/4), extremely channery sandy loam; massive; friable; $25 \%$ subangular 
sandstone-siltstone gravel and 40\% subangular sandstone-siltstone channers and 10\% subangular

sandstone-siltstone flagstones; abrupt smooth boundary. 96P0898

R--165 cm. Siltstone shale bedrock. 


\section{APPENDIX B}

\section{BASIC PEDON CHARACTERIZATION DATA FOR THE SERIES}


Basic characterization data for the Blackwater pedons.

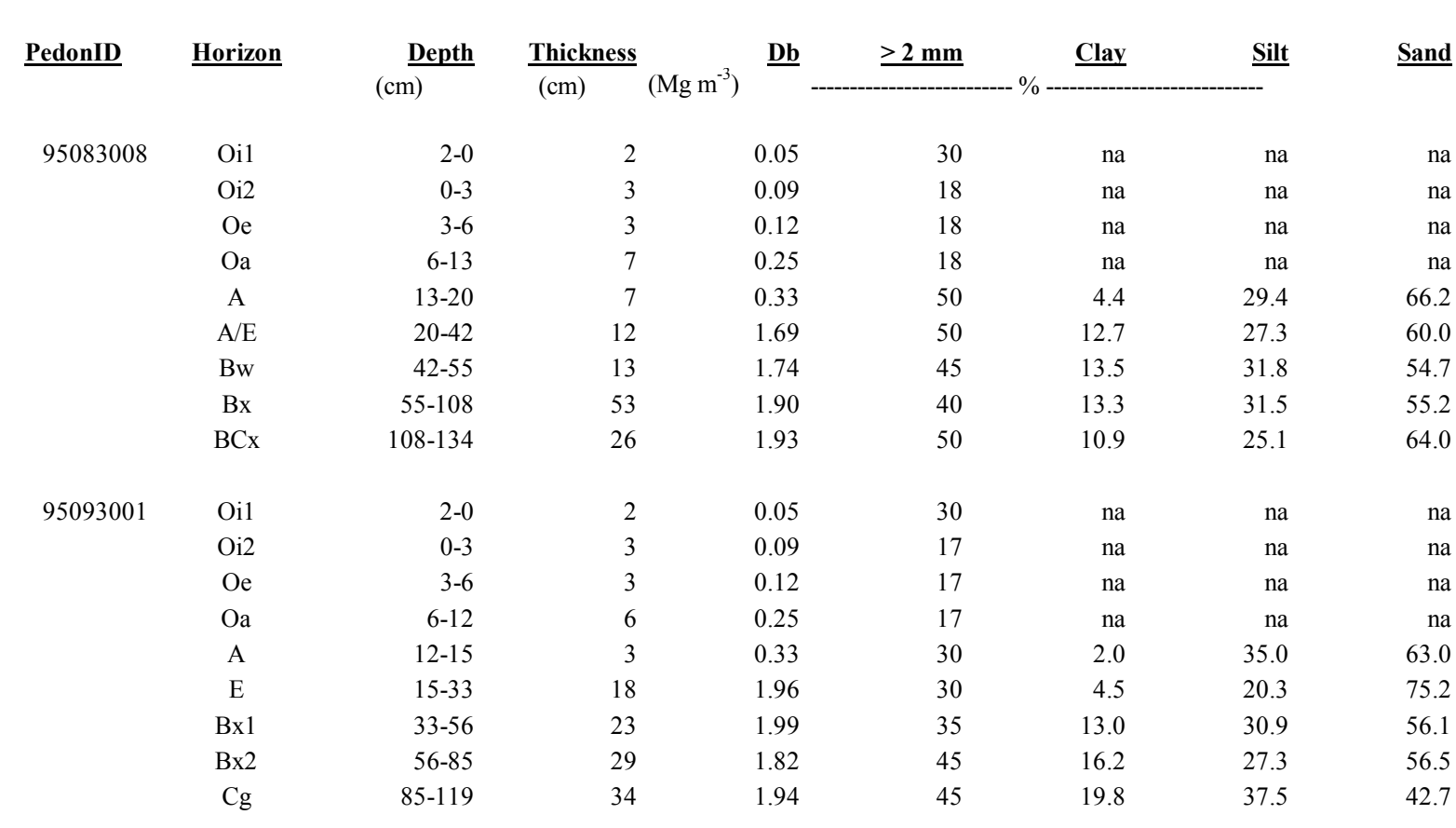

Basic characterization data for the Blackwater pedons (continued).

\begin{tabular}{|c|c|c|c|c|c|c|c|}
\hline \multirow[t]{2}{*}{$\underline{\text { PedonID }}$} & \multirow[t]{2}{*}{ Horizon } & \multirow{2}{*}{$\underset{(\mathrm{cm})}{\underline{\text { Depth }}}$} & \multirow{2}{*}{$\left(\mathrm{Cmol} \mathrm{kg}^{-1}\right) \frac{\text { CEC }}{-1}$} & \multirow{2}{*}{$\frac{\text { Org. C }}{\%}$} & \multirow{2}{*}{$\frac{\text { Total C }}{\%}$} & \multirow{2}{*}{$\frac{\text { Extr. Ca }}{\mathrm{mg} \mathrm{kg}^{-1}}$} & \multirow[t]{2}{*}{$\underline{\text { Total Ca }}$} \\
\hline & & & & & & & \\
\hline \multirow{9}{*}{95083008} & Oil & $2-0$ & nd & 53.40 & nd & nd & 6113 \\
\hline & Oi2 & $0-3$ & 97.1 & 55.40 & nd & 3387 & 2708 \\
\hline & Oe & $3-6$ & 117.9 & 55.10 & nd & 1383 & 1023 \\
\hline & $\mathrm{Oa}$ & $6-13$ & 125.7 & 49.50 & nd & 701 & 671 \\
\hline & A & $13-20$ & 35.4 & 9.85 & nd & 140 & 132 \\
\hline & $\mathrm{A} / \mathrm{E}$ & $20-42$ & 5.9 & 1.10 & nd & 0 & 40 \\
\hline & $\mathrm{Bw}$ & $42-55$ & 5.4 & 0.45 & nd & 0 & 115 \\
\hline & $\mathrm{Bx}$ & $55-108$ & 4.6 & 0.32 & nd & 0 & 64 \\
\hline & $\mathrm{BCx}$ & $108-134$ & 3.6 & 0.21 & nd & 0 & 56 \\
\hline \multirow[t]{9}{*}{95093001} & Oi1 & $2-0$ & nd & 54.70 & 50.37 & nd & 3547 \\
\hline & Oi2 & $0-3$ & 136.4 & 54.60 & 48.89 & 1944 & 2242 \\
\hline & Oe & $3-6$ & 146.0 & 50.60 & 44.63 & 561 & 931 \\
\hline & $\mathrm{Oa}$ & $6-12$ & 113.2 & 42.40 & 38.23 & 361 & 717 \\
\hline & $\mathrm{A}$ & $12-15$ & 48.8 & 18.60 & 18.92 & 240 & 461 \\
\hline & E & $15-33$ & 2.4 & 0.33 & 0.34 & 10 & 327 \\
\hline & $\mathrm{Bx} 1$ & $33-56$ & 4.7 & 0.26 & 0.27 & 20 & 365 \\
\hline & $\mathrm{Bx} 2$ & $56-85$ & 3.8 & 0.24 & 0.24 & 20 & 333 \\
\hline & $\mathrm{Cg}$ & $85-119$ & 5.3 & 0.66 & 0.68 & 60 & 240 \\
\hline
\end{tabular}


Basic characterization data for the Gauley pedons.

\begin{tabular}{|c|c|c|c|c|c|c|c|c|}
\hline$\underline{\text { PedonID }}$ & $\underline{\text { Horizon }}$ & $\underset{\text { (cm) }}{\text { Depth }}$ & $\frac{\text { Thickness }}{(\mathrm{cm})}$ & $\left(\mathrm{Mg} \mathrm{m}^{-3}\right)^{\underline{D b}}$ & $\geq 2 \mathrm{~mm}$ & $\underline{\text { Clay }}$ & $\underline{\text { Silt }}$ & $\underline{\text { Sand }}$ \\
\hline \multirow[t]{9}{*}{95075001} & Oil & $1-0$ & 1 & 0.05 & 30 & na & na & na \\
\hline & Oi2 & $0-3$ & 3 & 0.09 & 35 & na & na & na \\
\hline & $\mathrm{Oa}$ & $3-7$ & 4 & 0.25 & 25 & na & na & na \\
\hline & A & $7-11$ & 4 & 0.33 & 40 & 6.9 & 24.0 & 69.1 \\
\hline & E & $11-26$ & 15 & 1.76 & 50 & 13.6 & 15.7 & 80.7 \\
\hline & $\mathrm{Bh} / \mathrm{Bhs}$ & $26-38$ & 12 & 1.36 & 35 & 17.0 & 17.3 & 65.7 \\
\hline & $\mathrm{Bw}$ & $38-60$ & 22 & 1.53 & 45 & 10.6 & 13.2 & 76.2 \\
\hline & $\mathrm{BC}$ & $60-93$ & 33 & 1.53 & 50 & 4.0 & 8.8 & 87.2 \\
\hline & $\mathrm{C}$ & $93-123$ & 30 & 1.76 & 50 & 1.6 & 5.8 & 92.6 \\
\hline \multirow[t]{9}{*}{95075002} & Oil & $1-0$ & 1 & 0.05 & 30 & na & na & na \\
\hline & Oi2 & $0-3$ & 3 & 0.09 & 40 & na & na & na \\
\hline & Oe & $3-8$ & 5 & 0.12 & 40 & na & na & na \\
\hline & $\mathrm{Oa}$ & $8-13$ & 5 & 0.25 & 25 & na & na & na \\
\hline & $\mathrm{E}$ & $13-25$ & 12 & 1.82 & 35 & 9.3 & 29.5 & 61.2 \\
\hline & Bhs & $25-33$ & 8 & 1.66 & 25 & 12.7 & 23.2 & 64.1 \\
\hline & Bs & $33-41$ & 8 & 1.33 & 30 & 7.4 & 23.6 & 69.0 \\
\hline & $\mathrm{Bw}$ & $41-62$ & 21 & 1.73 & 50 & 5.5 & 28.3 & 66.2 \\
\hline & $\mathrm{C}$ & $62-93$ & 29 & 1.73 & 70 & 7.9 & 33.2 & 58.9 \\
\hline \multirow[t]{9}{*}{95093007} & Oil & $1-0$ & 1 & 0.05 & 30 & na & na & na \\
\hline & Oi2 & $0-4$ & 4 & 0.09 & 35 & na & na & na \\
\hline & Oe & $4-6$ & 2 & 0.12 & 35 & na & na & na \\
\hline & $\mathrm{Oa} / \mathrm{A}$ & $6-12$ & 6 & 0.25 & 75 & na & na & na \\
\hline & $\mathrm{AE}$ & $12-15$ & 3 & 0.55 & 75 & 0.0 & 11.9 & 88.1 \\
\hline & E & $15-50$ & 35 & 1.51 & 75 & 0.5 & 32.9 & 66.6 \\
\hline & $\mathrm{Bh}$ & $50-67$ & 17 & 1.09 & 45 & 12.6 & 34.2 & 53.2 \\
\hline & $\mathrm{Bw}$ & $67-93$ & 26 & 1.19 & 75 & 3.7 & 40.8 & 55.5 \\
\hline & $\mathrm{C}$ & $93-113$ & 40 & 1.33 & 55 & 3.7 & 39.0 & 57.3 \\
\hline \multirow[t]{10}{*}{95083003} & Oi1 & $1-0$ & 1 & 0.05 & 30 & na & na & na \\
\hline & Oi2 & $0-5$ & 5 & 0.09 & 15 & na & na & na \\
\hline & Oe & $5-8$ & 3 & 0.12 & 15 & na & na & na \\
\hline & A & $8-13$ & 5 & 0.33 & 70 & 3.7 & 17.2 & 79.1 \\
\hline & $\mathrm{AE}$ & $13-17$ & 4 & 0.55 & 70 & 8.6 & 13.8 & 77.6 \\
\hline & $\mathrm{E}$ & $17-28$ & 11 & 1.66 & 60 & 2.3 & 11.7 & 86.0 \\
\hline & $\mathrm{Bh}$ & $28-34$ & 6 & 1.37 & 50 & 2.4 & 12.9 & 84.7 \\
\hline & Bhs & $34-40$ & 6 & 1.34 & 50 & 10.8 & 20.4 & 68.8 \\
\hline & $\mathrm{Bhs} / \mathrm{BC}$ & $40-53$ & 13 & 1.64 & 60 & 7.0 & 22.4 & 70.6 \\
\hline & $\mathrm{C}$ & $53-68$ & 15 & 1.74 & 70 & 4.8 & 21.7 & 73.5 \\
\hline
\end{tabular}


Basic characterization data for the Gauley pedons (continued).

\begin{tabular}{|c|c|c|c|c|c|c|c|c|}
\hline$\underline{\text { PedonID }}$ & $\underline{\text { Horizon }}$ & $\underset{\text { (cm) }}{\stackrel{\text { Depth }}{\text { (cm) }}}$ & $\frac{\text { CEC }}{\left(\mathrm{Cmol} \mathrm{kg}^{-1}\right)}$ & $\frac{\text { Org. C }}{\%}$ & $\frac{\text { Total C }}{\%}$ & Extr. Ca & $\frac{\text { Total Ca }}{\mathrm{g}^{-1}}$ & Extr. Mg \\
\hline \multirow[t]{9}{*}{95075001} & Oil & $1-0$ & nd & 61.90 & 53.18 & nd & 1277 & nd \\
\hline & Oi2 & $0-3$ & 110.8 & 56.30 & 50.14 & 421 & 549 & 134 \\
\hline & $\mathrm{Oa}$ & $3-7$ & 94.1 & 39.80 & 36.30 & 261 & 272 & 97 \\
\hline & A & $7-11$ & 29.9 & 12.40 & 13.83 & 80 & 120 & 36 \\
\hline & E & $11-26$ & 2.0 & 0.54 & 0.53 & 20 & 43 & 0 \\
\hline & $\mathrm{Bh} / \mathrm{Bhs}$ & $26-38$ & 20.9 & 3.12 & 3.40 & 40 & 54 & 0 \\
\hline & $\mathrm{Bw}$ & $38-60$ & 8.6 & 0.79 & 0.97 & 20 & 72 & 0 \\
\hline & $\mathrm{BC}$ & $60-93$ & 3.1 & 0.32 & 0.33 & 20 & 77 & 0 \\
\hline & $\mathrm{C}$ & $93-123$ & 2.1 & 0.13 & 0.17 & 20 & 51 & 0 \\
\hline \multirow[t]{9}{*}{95075002} & Oil & $1-0$ & nd & 51.70 & 51.42 & nd & 1215 & nd \\
\hline & Oi2 & $0-3$ & 86.8 & 55.30 & 51.68 & 1022 & 999 & 219 \\
\hline & Oe & $3-8$ & 124.9 & 51.40 & 50.59 & 862 & 918 & 194 \\
\hline & $\mathrm{Oa}$ & $8-13$ & 117.6 & 46.40 & 43.59 & 321 & 390 & 36 \\
\hline & E & $13-25$ & 10.7 & 1.58 & 1.61 & 40 & 53 & 0 \\
\hline & Bhs & $25-33$ & 17.3 & 2.21 & 2.36 & 60 & 65 & 0 \\
\hline & Bs & $33-41$ & 10.2 & 0.84 & 1.02 & 40 & 60 & 0 \\
\hline & $\mathrm{Bw}$ & $41-62$ & 6.0 & 0.46 & 0.53 & 10 & 71 & 6 \\
\hline & $\mathrm{C}$ & $62-93$ & 8.1 & 0.75 & 0.83 & 10 & 79 & 6 \\
\hline \multirow[t]{9}{*}{95093007} & Oil & $1-0$ & nd & 54.80 & 48.15 & nd & nd & nd \\
\hline & Oi2 & $0-4$ & 74.6 & 57.60 & 50.99 & 1263 & 1238 & 182 \\
\hline & Oe & $4-6$ & 104.6 & 55.20 & 49.06 & 1383 & 1271 & 207 \\
\hline & $\mathrm{Oa} / \mathrm{A}$ & $6-12$ & 121.2 & 49.60 & 42.50 & 721 & 620 & 122 \\
\hline & $\mathrm{AE}$ & $12-15$ & 26.7 & 11.60 & 12.31 & 100 & 133 & 24 \\
\hline & $\mathrm{E}$ & $15-50$ & 2.7 & 0.41 & 0.73 & 0 & 36 & 6 \\
\hline & $\mathrm{Bh}$ & $50-67$ & 16.7 & 5.17 & 6.52 & 0 & 130 & 12 \\
\hline & $\mathrm{Bw}$ & $67-93$ & 10.2 & 1.24 & 1.37 & 0 & 117 & 6 \\
\hline & $\mathrm{C}$ & $93-113$ & 6.6 & 0.83 & 1.00 & 0 & 115 & 6 \\
\hline \multirow[t]{10}{*}{95083003} & Oil & $1-0$ & nd & 55.90 & 54.23 & nd & 2190 & nd \\
\hline & Oi2 & $0-5$ & 76.5 & 59.80 & 51.85 & 882 & 833 & 134 \\
\hline & Oe & $5-8$ & 115.3 & 55.70 & 49.61 & 822 & 738 & 146 \\
\hline & A & $8-13$ & 31.7 & 10.20 & 16.54 & 140 & 240 & 36 \\
\hline & $\mathrm{AE}$ & $13-17$ & 17.7 & 2.42 & no data & 0 & 47 & 6 \\
\hline & E & $17-28$ & 1.1 & 0.17 & no data & 0 & 39 & 0 \\
\hline & $\mathrm{Bh}$ & $28-34$ & 1.7 & 0.47 & no data & 0 & 36 & 0 \\
\hline & Bhs & $34-40$ & 18.4 & 2.32 & no data & 0 & 45 & 6 \\
\hline & $\mathrm{Bhs} / \mathrm{BC}$ & $40-53$ & 9.2 & 0.97 & no data & 0 & 63 & 0 \\
\hline & C & $53-68$ & 3.8 & 0.41 & no data & 0 & 35 & 0 \\
\hline
\end{tabular}


Basic characterization data for the Gauley pedons (continued).

\begin{tabular}{|c|c|c|c|c|c|c|c|c|}
\hline$\underline{\text { PedonID }}$ & $\underline{\text { Horizon }}$ & $\underset{\text { (cm) }}{\text { Depth }}$ & $\underline{\text { Total Mg }}$ & $\underline{\text { Extr. K }}$ & $\frac{\text { Extr.P }}{\text { mg kg-1- }}$ & $\underline{\text { Total P }}$ & $\mathrm{pH}(\mathrm{H} 2 \mathrm{O})$ & $\frac{\text { ECEC }}{\left.\mathrm{kg}^{-1}\right)}$ \\
\hline \multirow{9}{*}{95075001} & Oi1 & $1-0$ & 145 & nd & nd & 568 & nd & nd \\
\hline & Oi2 & $0-3$ & 113 & 469 & 65 & 533 & & 9.0 \\
\hline & $\mathrm{Oa}$ & $3-7$ & 83 & 391 & 63 & 547 & & 12.1 \\
\hline & A & $7-11$ & 37 & 117 & 31 & 246 & 3.2 & 5.3 \\
\hline & E & $11-26$ & 5 & 20 & 2 & 18 & 3.5 & 1.6 \\
\hline & $\mathrm{Bh} / \mathrm{Bhs}$ & $26-38$ & 31 & 39 & 18 & 126 & 3.4 & 8.7 \\
\hline & $\mathrm{Bw}$ & $38-60$ & 586 & 20 & 5 & 162 & 4.3 & 5.5 \\
\hline & $\mathrm{BC}$ & $60-93$ & 417 & 20 & 16 & 151 & 4.6 & 2.6 \\
\hline & $\mathrm{C}$ & $93-123$ & 143 & 20 & 17 & 118 & 4.8 & 2.1 \\
\hline \multirow[t]{9}{*}{95075002} & Oi1 & $1-0$ & 129 & nd & nd & 262 & nd & nd \\
\hline & Oi2 & $0-3$ & 236 & 782 & 112 & 692 & nd & 11.9 \\
\hline & Oe & $3-8$ & 238 & 430 & 79 & 630 & nd & 13.0 \\
\hline & $\mathrm{Oa}$ & $8-13$ & 95 & 274 & 59 & 502 & nd & 13.1 \\
\hline & E & $13-25$ & 34 & 20 & 5 & 74 & 3.4 & \\
\hline & Bhs & $25-33$ & 159 & 20 & 2 & 203 & 3.5 & 9.3 \\
\hline & Bs & $33-41$ & 490 & 20 & 0 & 183 & 4.0 & 7.1 \\
\hline & $\mathrm{Bw}$ & $41-62$ & 610 & 20 & 0 & 202 & 4.1 & 5.1 \\
\hline & $\mathrm{C}$ & $62-93$ & 811 & 20 & 0 & 200 & 4.3 & 6.0 \\
\hline \multirow[t]{9}{*}{95093007} & Oi1 & $1-0$ & 112 & nd & nd & 426 & nd & nd \\
\hline & Oi2 & $0-4$ & 181 & 900 & 262 & 774 & nd & 13.0 \\
\hline & Oe & $4-6$ & 244 & 626 & 127 & 717 & nd & 13.9 \\
\hline & $\mathrm{Oa} / \mathrm{A}$ & $6-12$ & 172 & 274 & 43 & 560 & nd & 9.0 \\
\hline & $\mathrm{AE}$ & $12-15$ & 67 & 39 & 9 & 148 & 3.2 & 3.7 \\
\hline & E & $15-50$ & 20 & 20 & 5 & 50 & 3.5 & 1.5 \\
\hline & $\mathrm{Bh}$ & $50-67$ & 278 & 39 & 0 & 247 & 3.5 & 13.5 \\
\hline & $\mathrm{Bw}$ & $67-93$ & 516 & 20 & 0 & 143 & 4.3 & 5.1 \\
\hline & $\mathrm{C}$ & $93-113$ & 562 & 20 & 7 & 163 & 4.6 & 3.2 \\
\hline \multirow[t]{10}{*}{95083003} & Oi1 & $1-0$ & 198 & nd & nd & 580 & nd & nd \\
\hline & Oi2 & $0-5$ & 118 & 704 & 212 & 622 & nd & 9.7 \\
\hline & Oe & $5-8$ & 212 & 548 & 163 & 644 & 3.6 & 8.4 \\
\hline & A & $8-13$ & 86 & 117 & 21 & 215 & 3.7 & 3.5 \\
\hline & $\mathrm{AE}$ & $13-17$ & 57 & 20 & 3 & 87 & 3.4 & 3.7 \\
\hline & E & $17-28$ & 13 & 20 & 1 & 35 & 3.7 & 0.3 \\
\hline & $\mathrm{Bh}$ & $28-34$ & 11 & 20 & 4 & 39 & 3.7 & 0.3 \\
\hline & Bhs & $34-40$ & 228 & 20 & 0 & 119 & 3.8 & 4.3 \\
\hline & $\mathrm{Bhs} / \mathrm{BC}$ & $40-53$ & 585 & 20 & 0 & 93 & 4.1 & 3.3 \\
\hline & $\mathrm{C}$ & 53-68 & 203 & 20 & 7 & 53 & 4.5 & 1.6 \\
\hline
\end{tabular}


Basic characterization data for the Gauley pedons (continued).

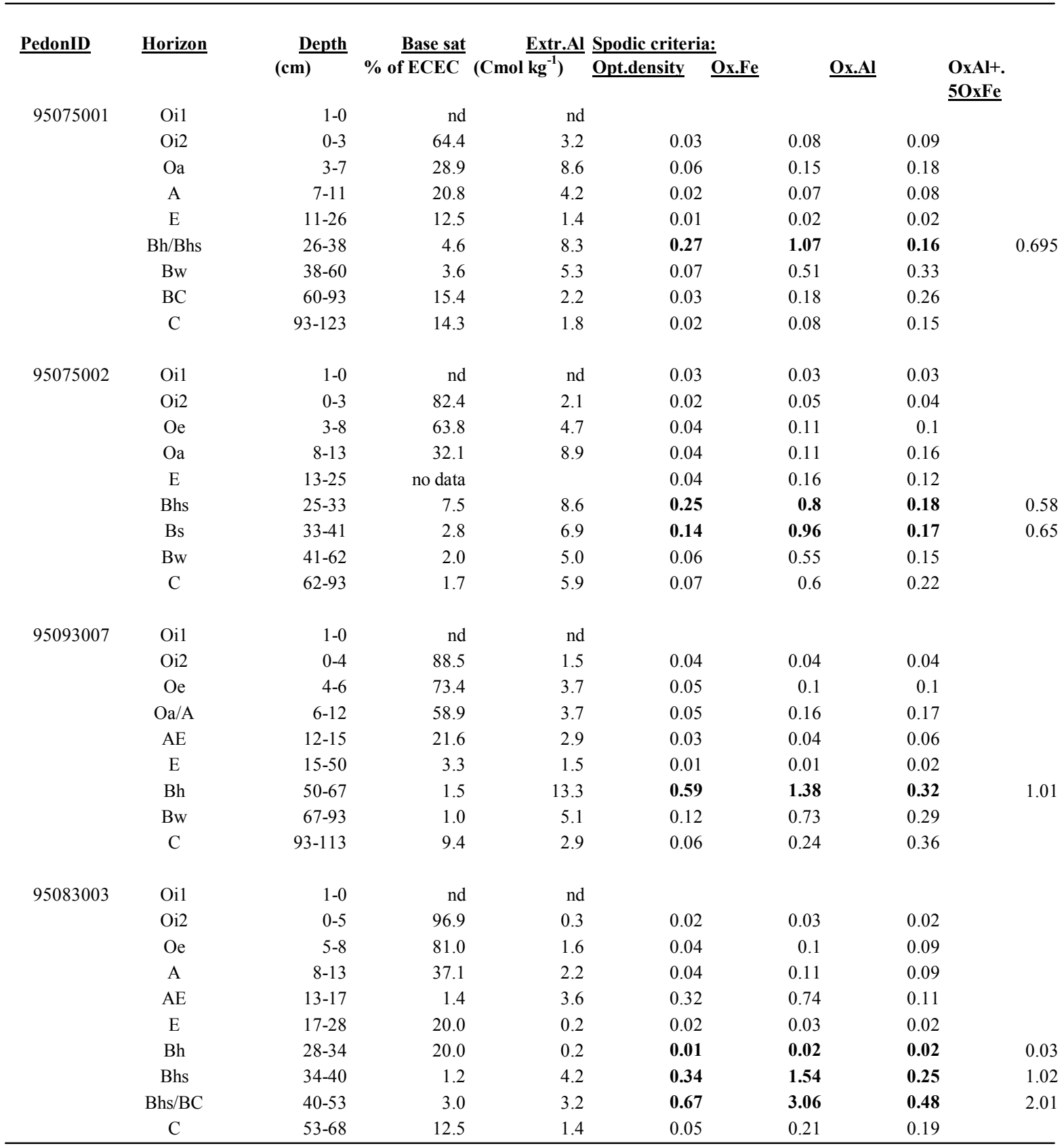


Basic characterization data for MWD Gauley pedons.

\begin{tabular}{|c|c|c|c|c|c|c|c|c|}
\hline$\underline{\text { PedonID }}$ & $\underline{\text { Horizon }}$ & Depth & Thickness & $\underline{\mathrm{Db}}$ & $\geq 2 \mathrm{~mm}$ & $\underline{\text { Clay }}$ & $\underline{\text { Silt }}$ & $\underline{\text { Sand }}$ \\
\hline \multirow[t]{9}{*}{95083006} & Oi1 & $1-0$ & 1 & 0.05 & 30 & na & na & na \\
\hline & Oi2 & $0-3$ & 3 & 0.09 & 10 & na & na & na \\
\hline & Oe & $3-10$ & 7 & 0.12 & 10 & na & na & na \\
\hline & $\mathrm{Oa}$ & $10-17$ & 7 & 0.25 & 10 & na & na & na \\
\hline & A & $17-23$ & 6 & 0.33 & 20 & 1.8 & 15.1 & 83.1 \\
\hline & $\mathrm{E}$ & $23-30$ & 7 & 1.52 & 30 & 3.6 & 18.8 & 77.6 \\
\hline & EB & $30-44$ & 14 & 1.91 & 30 & 7.6 & 19.7 & 72.7 \\
\hline & $\mathrm{Bh}$ & $44-59$ & 14 & 1.51 & 60 & 12.1 & 10.4 & 77.5 \\
\hline & $\mathrm{C}$ & $59-80$ & 21 & 1.75 & 50 & 6.2 & 42.4 & 51.4 \\
\hline \multirow[t]{10}{*}{95083002} & Oi1 & $2-0$ & 2 & 0.05 & 30 & na & na & na \\
\hline & Oi2 & $0-4$ & 4 & 0.09 & 20 & na & na & na \\
\hline & $\mathrm{Oe}$ & $4-8$ & 4 & 0.12 & 20 & na & na & na \\
\hline & $\mathrm{Oa} / \mathrm{A}$ & $8-13$ & 5 & 0.25 & 5 & na & na & na \\
\hline & $\mathrm{AE}$ & $13-21$ & 8 & 1.56 & 40 & 3.0 & 23.5 & 73.5 \\
\hline & $\mathrm{E}$ & $21-32$ & 11 & 1.92 & 40 & 3.1 & 15.8 & 81.1 \\
\hline & $\mathrm{Bh}$ & $32-40$ & 8 & 1.48 & 20 & 11.9 & 20.2 & 67.9 \\
\hline & $\mathrm{Bh} / \mathrm{Bs}$ & $40-52$ & 12 & 1.45 & 30 & 10.4 & 17.6 & 72.0 \\
\hline & Bs & $52-57$ & 5 & 1.63 & 60 & 6.0 & 23.7 & 73.0 \\
\hline & $\mathrm{C}$ & $57-71$ & 14 & 1.71 & 75 & 1.7 & 16.7 & 81.6 \\
\hline \multirow[t]{9}{*}{95093002} & Oil & $2-0$ & 2 & 0.05 & 30 & na & na & na \\
\hline & Oi2 & $0-3$ & 3 & 0.09 & 20 & na & na & na \\
\hline & Oe & $3-5$ & 2 & 0.12 & 20 & na & na & na \\
\hline & A & $5-10$ & 5 & 0.33 & 5 & 8.1 & 42.7 & 49.2 \\
\hline & $\mathrm{E}$ & $10-18$ & 8 & 1.91 & 5 & 5.7 & 24.5 & 69.8 \\
\hline & $\mathrm{Bh}$ & $18-34$ & 16 & 1.62 & 5 & 6.0 & 10.8 & 83.2 \\
\hline & Bsm & $34-41$ & 7 & 1.80 & 5 & 12.1 & 26.2 & 61.7 \\
\hline & Bs & $41-58$ & 17 & 1.75 & 25 & 3.8 & 12.0 & 84.2 \\
\hline & $\mathrm{C}$ & $58-90$ & 32 & 2.06 & 15 & 6.0 & 36.0 & 58.0 \\
\hline \multirow[t]{10}{*}{95093003} & Oi1 & $2-0$ & 2 & 0.05 & 30 & na & na & na \\
\hline & Oi2 & $0-4$ & 4 & 0.09 & 5 & na & na & na \\
\hline & Oe & $4-7$ & 3 & 0.12 & 10 & na & na & na \\
\hline & $\mathrm{Oa}$ & $7-9$ & 2 & 0.25 & 10 & na & na & na \\
\hline & A & $9-11$ & 2 & 0.33 & 50 & 3.3 & 16.3 & 80.4 \\
\hline & $\mathrm{E}$ & $11-24$ & 13 & 1.82 & 50 & 4.9 & 23.1 & 72.0 \\
\hline & $\mathrm{Bh}$ & $24-29$ & 5 & 1.79 & 15 & 9.1 & 17.8 & 73.1 \\
\hline & $\mathrm{Bw}$ & $29-43$ & 14 & 1.73 & 10 & 11.3 & 15.6 & 73.1 \\
\hline & $\mathrm{BC}$ & $43-52$ & 9 & 1.78 & 10 & 7.0 & 25.3 & 67.7 \\
\hline & $\mathrm{C}$ & $52-83$ & 31 & 1.83 & 10 & 4.7 & 33.6 & 61.7 \\
\hline
\end{tabular}


Basic characterization data for MWD Gauley pedons (continued).

\begin{tabular}{|c|c|c|c|c|c|c|c|}
\hline \multirow[t]{2}{*}{$\underline{\text { PedonID }}$} & \multirow[t]{2}{*}{ Horizon } & \multirow{2}{*}{$\underset{\text { (cm) }}{\underline{\text { Depth }}}$} & \multirow{2}{*}{$\frac{\mathrm{CEC}}{\left(\mathrm{Cmol} \mathrm{kg}^{-1}\right)}$} & \multirow{2}{*}{$\underset{\%}{\text { Org. C }}$} & \multirow{2}{*}{$\frac{\text { Total C }}{\%}$} & \multirow{2}{*}{$\frac{\text { Extr. Ca }}{-\mathrm{mg} \mathrm{kg}^{-1}}$} & \multirow[t]{2}{*}{$\underline{\text { Total Ca }}$} \\
\hline & & & & & & & \\
\hline \multirow[t]{9}{*}{95083006} & Oil & $1-0$ & nd & 56.20 & 53.44 & nd & 2628 \\
\hline & Oi2 & $0-3$ & 103.0 & 54.00 & 52.62 & 1503 & 1398 \\
\hline & Oe & $3-10$ & 121.3 & 42.70 & 45.39 & 361 & 433 \\
\hline & $\mathrm{Oa}$ & $10-17$ & 57.5 & 17.40 & 15.59 & 160 & 181 \\
\hline & A & $17-23$ & 32.7 & 9.54 & 12.72 & 80 & 1 \\
\hline & E & $23-30$ & 0.9 & 0.25 & 0.24 & 20 & 3 \\
\hline & EB & $30-44$ & 2.9 & 0.38 & 0.35 & 10 & 54 \\
\hline & $\mathrm{Bh}$ & $44-59$ & 11.4 & 1.20 & 0.14 & 0 & 31 \\
\hline & $\mathrm{C}$ & $59-80$ & 4.9 & 0.57 & 0.14 & 0 & 71 \\
\hline \multirow[t]{10}{*}{95083002} & Oil & $2-0$ & nd & 56.10 & 51.79 & nd & 1166 \\
\hline & Oi2 & $0-4$ & 105.7 & 55.50 & 49.06 & 882 & 720 \\
\hline & Oe & $4-8$ & 124.7 & 54.60 & 47.52 & 421 & 445 \\
\hline & $\mathrm{Oa} / \mathrm{A}$ & $8-13$ & 86.1 & 42.70 & 33.96 & 180 & 165 \\
\hline & $\mathrm{AE}$ & $13-21$ & 4.9 & 1.26 & no data & 20 & 28 \\
\hline & $\mathrm{E}$ & $21-32$ & 1.7 & 0.36 & no data & 20 & 44 \\
\hline & $\mathrm{Bh}$ & $32-40$ & 15.8 & 2.80 & no data & 20 & 46 \\
\hline & $\mathrm{Bh} / \mathrm{Bs}$ & $40-52$ & 11.2 & 1.14 & no data & 20 & 63 \\
\hline & Bs & $52-57$ & 4.3 & 0.34 & no data & 20 & 83 \\
\hline & $\mathrm{C}$ & $57-71$ & 1.5 & 0.15 & no data & 60 & 77 \\
\hline \multirow[t]{9}{*}{95093002} & Oil & $2-0$ & nd & 53.80 & 45.76 & nd & 6248 \\
\hline & Oi2 & $0-3$ & 126.3 & 54.30 & 48.59 & 4088 & 3973 \\
\hline & Oe & $3-5$ & 135.2 & 41.60 & 46.68 & 4248 & 4058 \\
\hline & A & $5-10$ & 120.0 & 15.50 & 49.01 & 2064 & 2126 \\
\hline & E & $10-18$ & 56.9 & 0.90 & 26.07 & 100 & 275 \\
\hline & $\mathrm{Bh}$ & $18-34$ & 5.4 & 1.21 & no data & 200 & 169 \\
\hline & Bsm & $34-41$ & 13.2 & 1.20 & no data & 60 & 132 \\
\hline & Bs & $41-58$ & 5.2 & 0.74 & no data & 60 & 116 \\
\hline & $\mathrm{C}$ & $58-90$ & 4.8 & 0.46 & no data & 0 & 77 \\
\hline \multirow[t]{10}{*}{95093003} & Oi1 & $2-0$ & nd & 56.00 & 51.64 & nd & 1531 \\
\hline & Oi2 & $0-4$ & 122.5 & 56.00 & 49.34 & 882 & 972 \\
\hline & $\mathrm{Oe}$ & $4-7$ & 155.9 & 49.60 & 46.79 & 421 & 458 \\
\hline & $\mathrm{Oa}$ & $7-9$ & 107.8 & 29.80 & 35.31 & 261 & 266 \\
\hline & A & $9-11$ & 44.9 & 13.60 & no data & 80 & 99 \\
\hline & E & $11-24$ & 3.5 & 1.04 & no data & 10 & 32 \\
\hline & $\mathrm{Bh}$ & $24-29$ & 10.8 & 1.71 & no data & 20 & 143 \\
\hline & $\mathrm{Bw}$ & $29-43$ & 9.3 & 0.65 & no data & 20 & 188 \\
\hline & $\mathrm{BC}$ & $43-52$ & 4.3 & 0.31 & no data & 10 & 161 \\
\hline & $\mathrm{C}$ & $52-83$ & 4.3 & 0.35 & no data & 10 & 76 \\
\hline
\end{tabular}


Basic characterization data for MWD Gauley pedons (continued).

\begin{tabular}{|c|c|c|c|c|c|c|c|}
\hline$\underline{\text { PedonID }}$ & $\underline{\text { Horizon }}$ & Depth & $\underline{\text { Extr. Ca }}$ & $\underline{\text { Total Ca }}$ & Extr. Mg & $\underline{\text { Total Mg }}$ & Extr. K \\
\hline \multirow[t]{9}{*}{95083006} & Oil & $1-0$ & nd & 2628 & nd & 282 & nd \\
\hline & Oi2 & $0-3$ & 1503 & 1398 & 170 & 225 & 88020 \\
\hline & Oe & $3-10$ & 361 & 433 & 146 & 186 & 72763 \\
\hline & $\mathrm{Oa}$ & $10-17$ & 160 & 181 & 61 & 59 & 23081 \\
\hline & A & $17-23$ & 80 & 1 & 24 & 14 & 5477 \\
\hline & $\mathrm{E}$ & $23-30$ & 20 & 3 & 6 & 31 & 12127 \\
\hline & EB & $30-44$ & 10 & 54 & 6 & 59 & 23081 \\
\hline & $\mathrm{Bh}$ & $44-59$ & 0 & 31 & 6 & 170 & 66504 \\
\hline & $\mathrm{C}$ & $59-80$ & 0 & 71 & 12 & 598 & 233938 \\
\hline \multirow[t]{10}{*}{95083002} & Oil & $2-0$ & nd & 1166 & nd & 119 & nd \\
\hline & Oi2 & $0-4$ & 882 & 720 & 170 & 112 & 43814 \\
\hline & $\mathrm{Oe}$ & $4-8$ & 421 & 445 & 146 & 117 & 45770 \\
\hline & $\mathrm{Oa} / \mathrm{A}$ & $8-13$ & 180 & 165 & 36 & 66 & 25819 \\
\hline & $\mathrm{AE}$ & $13-21$ & 20 & 28 & 6 & 7 & 2738 \\
\hline & $\mathrm{E}$ & $21-32$ & 20 & 44 & 6 & 5 & 1956 \\
\hline & $\mathrm{Bh}$ & $32-40$ & 20 & 46 & 12 & 21 & 8215 \\
\hline & $\mathrm{Bh} / \mathrm{Bs}$ & $40-52$ & 20 & 63 & 12 & 445 & 174084 \\
\hline & Bs & $52-57$ & 20 & 83 & 6 & 580 & 226896 \\
\hline & $\mathrm{C}$ & $57-71$ & 60 & 77 & 12 & 301 & 117751 \\
\hline \multirow[t]{9}{*}{95093002} & Oi1 & $2-0$ & nd & 6248 & nd & 507 & nd \\
\hline & Oi2 & $0-3$ & 4088 & 3973 & 425 & 424 & 165869 \\
\hline & $\mathrm{Oe}$ & $3-5$ & 4248 & 4058 & 389 & 393 & 153742 \\
\hline & A & $5-10$ & 2064 & 2126 & 134 & 187 & 73154 \\
\hline & E & $10-18$ & 100 & 275 & 6 & 31 & 12127 \\
\hline & $\mathrm{Bh}$ & $18-34$ & 200 & 169 & 12 & 74 & 28949 \\
\hline & Bsm & $34-41$ & 60 & 132 & 6 & 691 & 270319 \\
\hline & Bs & $41-58$ & 60 & 116 & 12 & 183 & 71590 \\
\hline & $\mathrm{C}$ & $58-90$ & 0 & 77 & 12 & 435 & 170172 \\
\hline \multirow[t]{10}{*}{95093003} & Oil & $2-0$ & nd & 1531 & nd & 138 & nd \\
\hline & Oi2 & $0-4$ & 882 & 972 & 292 & 146 & 57115 \\
\hline & Oe & $4-7$ & 421 & 458 & 292 & 179 & 70025 \\
\hline & $\mathrm{Oa}$ & $7-9$ & 261 & 266 & 158 & 117 & 45770 \\
\hline & $\mathrm{A}$ & $9-11$ & 80 & 99 & 49 & 38 & 14866 \\
\hline & E & $11-24$ & 10 & 32 & 6 & 4 & 1565 \\
\hline & $\mathrm{Bh}$ & $24-29$ & 20 & 143 & 6 & 147 & 57506 \\
\hline & $\mathrm{Bw}$ & $29-43$ & 20 & 188 & 6 & 740 & 289488 \\
\hline & $\mathrm{BC}$ & $43-52$ & 10 & 161 & 6 & 534 & 208901 \\
\hline & $\mathrm{C}$ & $52-83$ & 10 & 76 & 0 & 397 & 155306 \\
\hline
\end{tabular}


Basic characterization data for MWD Gauley pedons (continued).

\begin{tabular}{|c|c|c|c|c|c|c|c|c|}
\hline \multirow[t]{2}{*}{$\underline{\text { PedonID }}$} & \multirow[t]{2}{*}{ Horizon } & \multirow{2}{*}{$\underset{\text { (cm) }}{\underline{\text { Depth }}}$} & \multirow{2}{*}{$\frac{\text { Extr.P }}{\mathrm{mg} \mathrm{kg}^{-1}}$} & \multirow{2}{*}{$\underline{\text { Total P }}$} & \multirow{2}{*}{$\mathrm{pH}(\mathrm{H2O})$} & \multirow{2}{*}{$\frac{\text { ECEC }}{\left(\mathrm{Cmol} \mathrm{kg}^{-1}\right)}$} & \multirow{2}{*}{$\frac{\text { Base sat }}{\% \text { of ECEC }}$} & \multirow{2}{*}{$\left(\mathrm{Cmol} \mathrm{kg}^{-1}\right)$} \\
\hline & & & & & & & & \\
\hline \multirow[t]{9}{*}{95083006} & Oi1 & $1-0$ & nd & 788 & nd & nd & nd & nd \\
\hline & Oi2 & $0-3$ & 164 & 869 & nd & 16.1 & 85.7 & 2.3 \\
\hline & Oe & $3-10$ & 29 & 434 & nd & 12.3 & 35.0 & 8.0 \\
\hline & $\mathrm{Oa}$ & $10-17$ & 6 & 180 & 2.8 & 6.4 & 23.4 & 4.9 \\
\hline & $\mathrm{A}$ & $17-23$ & 4 & 27 & 3.1 & 4.2 & 16.7 & 3.5 \\
\hline & E & $23-30$ & 3 & 105 & 3.7 & 0.8 & 12.5 & 0.7 \\
\hline & EB & $30-44$ & 2 & 52 & 3.7 & 3.4 & 1.5 & 3.4 \\
\hline & $\mathrm{Bh}$ & $44-59$ & 49 & 152 & 3.9 & 7.1 & 0.7 & 7.1 \\
\hline & $\mathrm{C}$ & $59-80$ & 10 & 103 & 4.7 & 3.5 & 2.9 & 3.4 \\
\hline \multirow[t]{10}{*}{95083002} & Oi1 & $2-0$ & nd & 603 & nd & nd & nd & nd \\
\hline & Oi2 & $0-4$ & 96 & 644 & nd & 10.2 & 92.2 & 0.9 \\
\hline & Oe & $4-8$ & 61 & 607 & nd & 8.3 & 77.1 & 1.9 \\
\hline & $\mathrm{Oa} / \mathrm{A}$ & $8-13$ & 37 & 433 & nd & 5.4 & 63.0 & 2.0 \\
\hline & $\mathrm{AE}$ & $13-21$ & 3 & 13 & 3.5 & 0.4 & 25.0 & 0.3 \\
\hline & E & $21-32$ & 1 & 6 & 3.5 & 0.4 & 25.0 & 0.3 \\
\hline & $\mathrm{Bh}$ & $32-40$ & 2 & 75 & 3.2 & 6.4 & 4.7 & 6.1 \\
\hline & $\mathrm{Bh} / \mathrm{Bs}$ & $40-52$ & 0 & 66 & 3.8 & 4.7 & 4.3 & 4.5 \\
\hline & Bs & $52-57$ & 0 & 50 & 4.4 & 2.5 & 8.0 & 2.3 \\
\hline & $\mathrm{C}$ & $57-71$ & 8 & 48 & 4.6 & 1.0 & 40.0 & 0.6 \\
\hline \multirow[t]{9}{*}{95093002} & Oil & $2-0$ & nd & 650 & nd & nd & nd & nd \\
\hline & Oi2 & $0-3$ & 124 & 699 & 4.1 & 32.0 & 98.1 & 0.6 \\
\hline & Oe & $3-5$ & 88 & 596 & 4.0 & 36.1 & 96.7 & 1.2 \\
\hline & A & $5-10$ & 24 & 328 & 4.0 & 24.8 & 92.7 & 1.8 \\
\hline & E & $10-18$ & 2 & 30 & 4.0 & 14.1 & 95.0 & 0.7 \\
\hline & $\mathrm{Bh}$ & $18-34$ & 4 & 58 & 4.0 & 3.1 & 45.2 & 2.4 \\
\hline & Bsm & $34-41$ & 0 & 154 & 4.4 & 4.7 & 10.6 & 4.2 \\
\hline & Bs & $41-58$ & 8 & 90 & 4.1 & 2.7 & 33.3 & 1.8 \\
\hline & $\mathrm{C}$ & $58-90$ & 9 & 75 & 4.8 & 1.7 & 17.6 & 1.4 \\
\hline \multirow[t]{10}{*}{95093003} & Oi1 & $2-0$ & nd & 741 & nd & nd & nd & nd \\
\hline & Oi2 & $0-4$ & 82 & 509 & nd & 12.4 & 83.1 & 2.1 \\
\hline & $\mathrm{Oe}$ & $4-7$ & 64 & 512 & 3.1 & 14.2 & 43.0 & 8.1 \\
\hline & $\mathrm{Oa}$ & $7-9$ & 40 & 396 & 3.3 & 11.8 & 38.1 & 7.3 \\
\hline & A & $9-11$ & 26 & 264 & 3.3 & 5.6 & 23.2 & 4.3 \\
\hline & E & $11-24$ & 5 & 28 & 3.4 & 1.5 & 3.4 & 1.4 \\
\hline & $\mathrm{Bh}$ & $24-29$ & 4 & 73 & 3.4 & 5.2 & 1.9 & 5.1 \\
\hline & $\mathrm{Bw}$ & $29-43$ & 0 & 123 & 4.1 & 6.1 & 3.3 & 5.9 \\
\hline & $\mathrm{BC}$ & $43-52$ & 5 & 99 & 4.5 & 2.6 & 2.0 & 2.5 \\
\hline & $\mathrm{C}$ & $52-83$ & 11 & 103 & 4.8 & 1.5 & 3.4 & 1.4 \\
\hline
\end{tabular}


Basic characterization data for MWD Gauley pedons (continued).

\begin{tabular}{|c|c|c|c|c|c|c|}
\hline$\underline{\text { PedonID }}$ & $\underline{\text { Horizon }}$ & $\frac{\text { Depth }}{\text { (cm) }}$ & Opt.density & $\underline{\text { Ox.Fe }}$ & $\underline{\text { Ox.Al }}$ & $\frac{\text { OxAl+. }}{0.5 \text { OxFe }}$ \\
\hline \multirow[t]{9}{*}{95083006} & Oil & $1-0$ & & & & \\
\hline & Oi2 & $0-3$ & 0.05 & 0.09 & 0.06 & \\
\hline & Oe & $3-10$ & 0.04 & 0.15 & 0.20 & \\
\hline & $\mathrm{Oa}$ & $10-17$ & 0.02 & 0.10 & 0.11 & \\
\hline & $\mathrm{A}$ & $17-23$ & 0.02 & 0.07 & 0.07 & \\
\hline & E & $23-30$ & 0.00 & 0.01 & 0.01 & \\
\hline & EB & $30-44$ & 0.02 & 0.03 & 0.03 & \\
\hline & $\mathrm{Bh}$ & $44-59$ & 0.21 & 0.10 & 0.13 & 0.18 \\
\hline & $\mathrm{C}$ & $59-80$ & 0.10 & 0.15 & 0.16 & \\
\hline \multirow[t]{10}{*}{95083002} & Oi1 & $2-0$ & & & & \\
\hline & Oi2 & $0-4$ & 0.04 & 0.10 & 0.09 & \\
\hline & Oe & $4-8$ & 0.05 & 0.12 & 0.14 & \\
\hline & $\mathrm{Oa} / \mathrm{A}$ & $8-13$ & 0.08 & 0.15 & 0.17 & \\
\hline & $\mathrm{AE}$ & $13-21$ & 0.01 & 0.01 & 0.02 & \\
\hline & $\mathrm{E}$ & $21-32$ & 0.00 & 0.01 & 0.00 & \\
\hline & $\mathrm{Bh}$ & $32-40$ & 0.11 & 0.20 & 0.18 & 0.28 \\
\hline & $\mathrm{Bh} / \mathrm{Bs}$ & $40-52$ & 0.14 & 0.60 & 0.15 & 0.45 \\
\hline & Bs & $52-57$ & 0.05 & 0.32 & 0.13 & 0.29 \\
\hline & $\mathrm{C}$ & $57-71$ & 0.03 & 0.08 & 0.06 & \\
\hline \multirow[t]{9}{*}{95093002} & Oil & $2-0$ & & & & \\
\hline & Oi2 & $0-3$ & 0.05 & 0.09 & 0.19 & \\
\hline & $\mathrm{Oe}$ & $3-5$ & 0.05 & 0.17 & 0.17 & \\
\hline & A & $5-10$ & 0.09 & 0.23 & 0.22 & \\
\hline & $\mathrm{E}$ & $10-18$ & 0.05 & 0.22 & 0.14 & \\
\hline & $\mathrm{Bh}$ & $18-34$ & 0.02 & 0.02 & 0.03 & 0.04 \\
\hline & Bsm & $34-41$ & 0.34 & 1.70 & 0.35 & 1.20 \\
\hline & Bs & $41-58$ & 0.14 & 0.36 & 0.11 & 0.29 \\
\hline & $\mathrm{C}$ & $58-90$ & 0.06 & 0.12 & 0.29 & \\
\hline \multirow[t]{10}{*}{95093003} & Oi1 & $2-0$ & & & & \\
\hline & Oi2 & $0-4$ & 0.05 & 0.08 & 0.10 & \\
\hline & $\mathrm{Oe}$ & $4-7$ & 0.05 & 0.16 & 0.30 & \\
\hline & $\mathrm{Oa}$ & $7-9$ & 0.08 & 0.13 & 0.25 & \\
\hline & A & $9-11$ & 0.06 & 0.11 & 0.15 & \\
\hline & $\mathrm{E}$ & $11-24$ & 0.02 & 0.02 & 0.04 & \\
\hline & $\mathrm{Bh}$ & $24-29$ & 0.09 & 0.03 & 0.11 & 0.13 \\
\hline & $\mathrm{Bw}$ & $29-43$ & 0.09 & 0.79 & 0.24 & 0.64 \\
\hline & $\mathrm{BC}$ & $43-52$ & 0.04 & 0.23 & 0.21 & \\
\hline & $\mathrm{C}$ & $52-83$ & 0.03 & 0.15 & 0.30 & \\
\hline
\end{tabular}


Basic characterization data for Mandy pedons.

\begin{tabular}{|c|c|c|c|c|c|c|c|c|}
\hline Mandy & Horizon & $\underset{\text { (cm) }}{\text { Depth }}$ & $\frac{\text { Thickness }}{(\mathrm{cm})}$ & $\left(\mathrm{Mg} \mathrm{m}^{-3}\right)^{\underline{\mathrm{Db}}}$ & $>2 \mathrm{~mm}$ & Clay & $\underline{\text { Silt }}$ & $\underline{\text { Sand }}$ \\
\hline \multicolumn{9}{|l|}{$\underline{\text { Pedon ID }}$} \\
\hline \multirow{8}{*}{$\begin{array}{r}\text { s95083005 } \\
\text { (north) }\end{array}$} & Oil & $1-0$ & 1 & 0.05 & 30 & na & na & na \\
\hline & Oi2 & $0-2$ & 2 & 0.07 & 15 & na & na & na \\
\hline & Oe & $2-4$ & 2 & 0.10 & 15 & na & na & na \\
\hline & A & $4-13$ & 9 & 0.52 & 35 & 17.8 & 39.2 & 43.0 \\
\hline & BA & $13-25$ & 12 & 1.21 & 30 & 27.6 & 46.5 & 25.9 \\
\hline & Bw1 & $25-46$ & 21 & 1.30 & 40 & 29.3 & 38.7 & 32.0 \\
\hline & Bw2 & $46-79$ & 33 & 1.33 & 45 & 20.7 & 46.1 & 33.2 \\
\hline & $\mathrm{C}$ & 79-97 & 18 & 1.42 & 80 & 15.9 & 50.4 & 33.7 \\
\hline \multirow{6}{*}{$\begin{array}{r}\text { s95083007 } \\
\text { (south) }\end{array}$} & Oi1 & $1-0$ & 1 & 0.05 & 30 & na & na & na \\
\hline & Oi2 & $0-3$ & 3 & 0.07 & 30 & na & na & na \\
\hline & Oe & $3-6$ & 3 & 0.10 & 30 & na & na & na \\
\hline & A & 6-18 & 12 & 0.52 & 40 & 16.3 & 30.0 & 53.7 \\
\hline & $\mathrm{Bw}$ & $18-63$ & 45 & 0.94 & 50 & 18.4 & 34.1 & 47.5 \\
\hline & $\mathrm{BC}$ & $63-91$ & 28 & 1.08 & 70 & 16.1 & 34.0 & 49.9 \\
\hline \multirow{7}{*}{$\begin{array}{r}\text { s95093004 } \\
\text { (north) }\end{array}$} & Oi1 & $2-0$ & 2 & 0.05 & 30 & na & na & na \\
\hline & Oi2 & $0-3$ & 3 & 0.07 & 10 & na & na & na \\
\hline & Oe & $3-5$ & 2 & 0.10 & 20 & na & na & na \\
\hline & A & $5-15$ & 10 & 0.52 & 30 & 18.1 & 42.0 & 39.9 \\
\hline & $\mathrm{Bw}$ & $15-51$ & 36 & 1.03 & 35 & 33.7 & 40.6 & 25.7 \\
\hline & $\mathrm{BC}$ & $51-88$ & 37 & 1.45 & 60 & 14.2 & 36.4 & 49.4 \\
\hline & $2 \mathrm{C}$ & $88-108$ & 20 & 1.25 & 75 & 8.6 & 34.0 & 57.4 \\
\hline \multirow{8}{*}{$\begin{array}{r}\text { s95093005 } \\
\text { (south) }\end{array}$} & Oil & $2-0$ & 2 & 0.05 & 30 & na & na & na \\
\hline & Oi2 & $0-3$ & 3 & 0.07 & 40 & na & na & na \\
\hline & Oe & $3-5$ & 2 & 0.10 & 40 & na & na & na \\
\hline & A & $5-11$ & 6 & 0.52 & 35 & 14.2 & 41.1 & 44.7 \\
\hline & BA & $11-24$ & 13 & 1.12 & 30 & 29.1 & 38.5 & 32.4 \\
\hline & Bw & $24-46$ & 22 & 1.25 & 50 & 22.6 & 37.9 & 39.5 \\
\hline & $\mathrm{BC}$ & $46-67$ & 21 & 1.69 & 45 & 15.0 & 37.2 & 47.8 \\
\hline & $\mathrm{C}$ & $67-100$ & 33 & 1.60 & 80 & 12.6 & 41.8 & 45.6 \\
\hline
\end{tabular}


Basic characterization data for Mandy pedons (continued).

\begin{tabular}{|c|c|c|c|c|c|c|c|}
\hline Mandy & Horizon & $\underset{\text { (cm) }}{\underline{\text { Depth }}}$ & $\frac{\text { CEC }}{\left(\mathrm{Cmol} \mathrm{kg}^{-1}\right)}$ & $\frac{\text { Org. C }}{\%}$ & $\frac{\text { Total C }}{\%}$ & $\frac{\text { Extr. Ca }}{-\mathrm{mg} \mathrm{kg}^{-1}}$ & $\underline{\text { Total Ca }}$ \\
\hline \multicolumn{8}{|l|}{ Pedon ID } \\
\hline \multirow{8}{*}{$\begin{array}{r}\text { s95083005 } \\
\text { (north) }\end{array}$} & Oil & $1-0$ & nd & 51.60 & 50.30 & no data & 4711 \\
\hline & Oi2 & $0-2$ & 107.5 & 52.40 & 49.03 & 2826 & 2610 \\
\hline & Oe & $2-4$ & 100.2 & 43.10 & 48.24 & 281 & 701 \\
\hline & A & $4-13$ & 35.4 & 11.70 & 10.27 & 220 & 236 \\
\hline & BA & $13-25$ & 20.8 & 2.69 & 2.85 & 20 & 66 \\
\hline & Bw1 & $25-46$ & 12.9 & 1.74 & 1.52 & 20 & 92 \\
\hline & Bw2 & $46-79$ & 12 & 1.29 & 1.92 & 20 & 56 \\
\hline & $\mathrm{C}$ & 79-97 & 8.8 & 0.64 & 0.87 & 10 & 39 \\
\hline \multirow{6}{*}{$\begin{array}{r}\text { s95083007 } \\
\text { (south) }\end{array}$} & Oil & $1-0$ & nd & 49.40 & 5.41 & nd & 2383 \\
\hline & Oi2 & $0-3$ & 92.1 & 53.20 & 17.68 & 1884 & 1637 \\
\hline & Oe & $3-6$ & 116.1 & 50.70 & 15.61 & 822 & 849 \\
\hline & $\mathrm{A}$ & $6-18$ & 34.9 & 10.10 & 5.42 & 20 & 53 \\
\hline & $\mathrm{Bw}$ & $18-63$ & 12.3 & 2.42 & 2.57 & 0 & 68 \\
\hline & $\mathrm{BC}$ & 63-91 & 10.4 & 1.31 & 0.92 & 0 & 56 \\
\hline \multirow{7}{*}{$\begin{array}{r}\text { s95093004 } \\
\text { (north) }\end{array}$} & Oi1 & $2-0$ & nd & 51.60 & 46.19 & nd & 3262 \\
\hline & Oi2 & $0-3$ & 123.6 & 52.60 & 46.67 & 2004 & 2162 \\
\hline & Oe & $3-5$ & 116.7 & 50.50 & 43.02 & 1683 & 1700 \\
\hline & A & $5-15$ & 54.9 & 19.50 & 17.00 & 321 & 379 \\
\hline & $\mathrm{Bw}$ & $15-51$ & 21.5 & 1.55 & 2.12 & 20 & 64 \\
\hline & $\mathrm{BC}$ & $51-88$ & 10.3 & 0.88 & 1.10 & 20 & 80 \\
\hline & $2 \mathrm{C}$ & $88-108$ & 7.4 & 0.67 & 0.89 & 10 & 60 \\
\hline \multirow{8}{*}{$\begin{array}{r}\text { s95093005 } \\
\text { (south) }\end{array}$} & Oil & $2-0$ & nd & 52.90 & 47.00 & nd & 4070 \\
\hline & Oi2 & $0-3$ & 87.3 & 51.50 & 48.13 & 2425 & 2579 \\
\hline & $\mathrm{Oe}$ & $3-5$ & 87.1 & 43.20 & 36.40 & 1443 & 1530 \\
\hline & A & $5-11$ & 34.1 & 11.60 & 10.39 & 220 & 280 \\
\hline & BA & $11-24$ & 17.7 & 3.25 & 3.52 & 20 & 62 \\
\hline & $\mathrm{Bw}$ & $24-46$ & 10.4 & 1.24 & 1.59 & 20 & 47 \\
\hline & $\mathrm{BC}$ & $46-67$ & 7.4 & 0.52 & 0.73 & 20 & 134 \\
\hline & $\mathrm{C}$ & $67-100$ & 8.6 & 1.09 & 1.44 & 20 & 156 \\
\hline
\end{tabular}


Basic characterization data for Mandy pedons (continued).

\begin{tabular}{|c|c|c|c|c|c|c|c|c|}
\hline Mandy & Horizon & $\underset{\text { (cm) }}{\underline{\text { Depth }}}$ & Extr. Mg & $\underline{\text { Total Mg }}$ & Extr. K & $\frac{\text { Extr.P }}{\mathrm{mg} \mathrm{kg}^{-1}}$ & $\underline{\text { Total P }}$ & $\mathrm{pH}(\mathrm{H} 2 \mathrm{O})$ \\
\hline \multicolumn{9}{|l|}{ Pedon ID } \\
\hline \multirow{8}{*}{$\begin{array}{r}\text { s95083005 } \\
\text { (north) }\end{array}$} & Oil & $1-0$ & ppm & 1327 & ppm & & 1589 & nd \\
\hline & Oi2 & $0-2$ & 194 & 770 & 2582 & 585 & 1688 & nd \\
\hline & Oe & $2-4$ & 36 & 88 & 861 & 220 & 600 & 3.6 \\
\hline & A & $4-13$ & 36 & 68 & 117 & 37 & 654 & 3.1 \\
\hline & BA & $13-25$ & 12 & 309 & 39 & 4 & 391 & 3.3 \\
\hline & Bw1 & $25-46$ & 12 & 69 & 39 & 0 & 423 & 3.8 \\
\hline & Bw2 & $46-79$ & 6 & 1022 & 39 & 0 & 442 & 4.1 \\
\hline & $\mathrm{C}$ & $79-97$ & 6 & 710 & 39 & 5 & & 4.4 \\
\hline \multirow{6}{*}{$\begin{array}{r}\text { s95083007 } \\
\text { (south) }\end{array}$} & Oil & $1-0$ & nd & 214 & nd & nd & 688 & nd \\
\hline & Oi2 & $0-3$ & 207 & 179 & 704 & 230 & 800 & nd \\
\hline & Oe & $3-6$ & 146 & 226 & 626 & 100 & 747 & nd \\
\hline & A & $6-18$ & 24 & 213 & 78 & 7 & 449 & 3.1 \\
\hline & $\mathrm{Bw}$ & $18-63$ & 0 & 969 & 20 & 0 & 273 & 4.4 \\
\hline & $\mathrm{BC}$ & $63-91$ & 0 & 554 & 20 & 0 & 277 & 4.5 \\
\hline \multirow{7}{*}{$\begin{array}{r}\text { s95093004 } \\
\text { (north) }\end{array}$} & Oil & $2-0$ & nd & 504 & nd & nd & 913 & nd \\
\hline & Oi2 & $0-3$ & 462 & 422 & 1447 & 483 & 1070 & nd \\
\hline & Oe & $3-5$ & 255 & 382 & 626 & 263 & 823 & 3.7 \\
\hline & A & $5-15$ & 49 & 375 & 156 & 44 & 722 & 3.1 \\
\hline & $\mathrm{Bw}$ & $15-51$ & 6 & 725 & 39 & 0 & 417 & 3.9 \\
\hline & $\mathrm{BC}$ & $51-88$ & 6 & 1214 & 39 & 4 & 372 & 4.3 \\
\hline & $2 \mathrm{C}$ & $88-108$ & 6 & 721 & 20 & 9 & 345 & 4.5 \\
\hline \multirow{8}{*}{$\begin{array}{r}\text { s95093005 } \\
\text { (south) }\end{array}$} & Oil & $2-0$ & nd & 408 & nd & nd & 897 & nd \\
\hline & Oi2 & $0-3$ & 255 & 300 & 1134 & 229 & 849 & 4.5 \\
\hline & Oe & $3-5$ & 158 & 305 & 900 & 186 & 822 & 4.0 \\
\hline & A & $5-11$ & 36 & 185 & 117 & 42 & 488 & 3.3 \\
\hline & BA & $11-24$ & 12 & 406 & 39 & 6 & 512 & 3.6 \\
\hline & Bw & $24-46$ & 12 & 927 & 39 & 3 & 358 & 4.3 \\
\hline & $\mathrm{BC}$ & $46-67$ & 6 & 1021 & 39 & 4 & 254 & 4.6 \\
\hline & $\mathrm{C}$ & $67-100$ & 6 & 913 & 39 & 9 & 408 & 4.5 \\
\hline
\end{tabular}


Basic characterization data for Mandy pedons (continued).

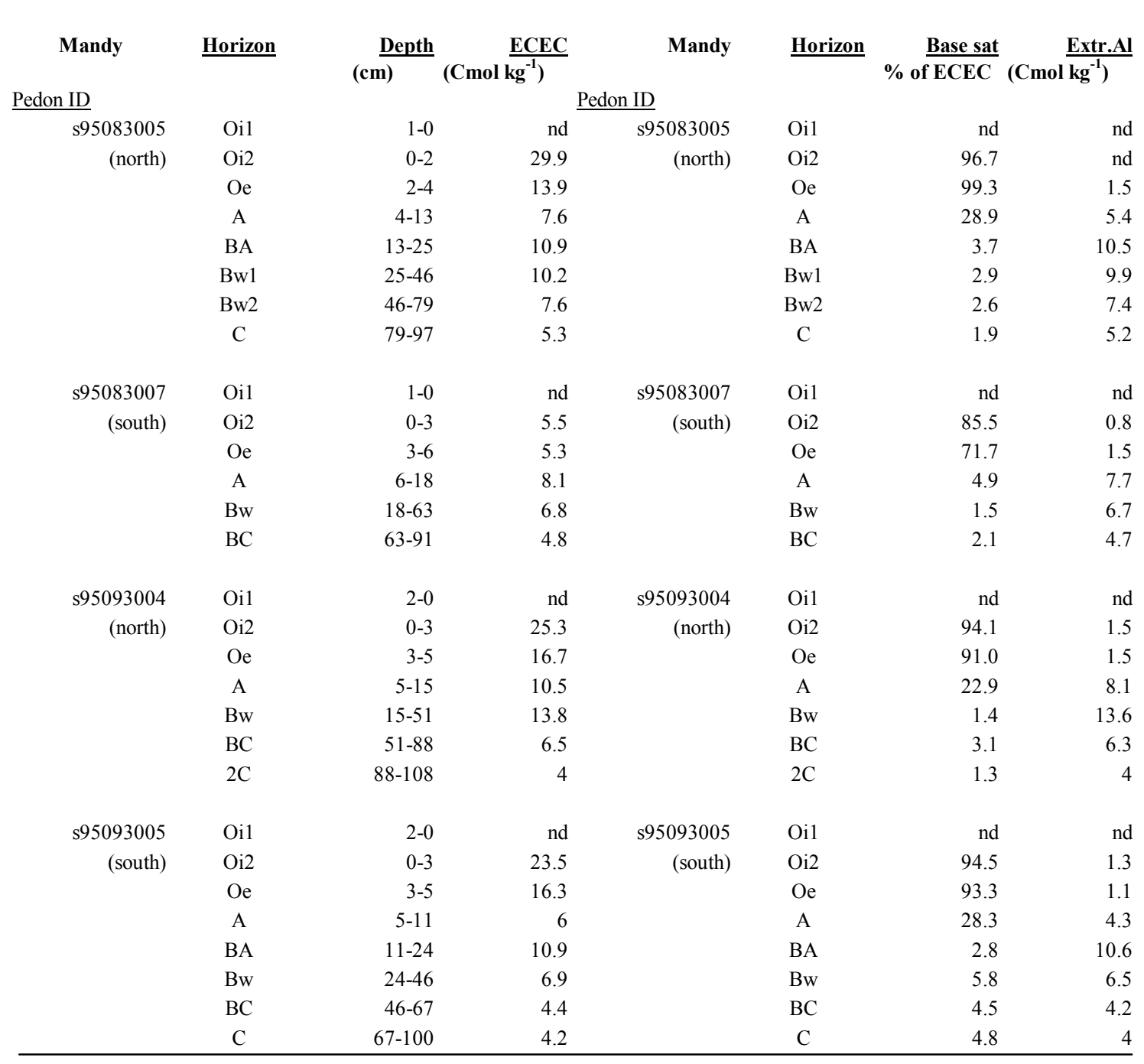


Basic characterization data for Mandy pedons (continued).

\begin{tabular}{|c|c|c|c|c|c|}
\hline Mandy & Horizon & Depth & $\underline{\text { Ox.Fe }}$ & $\underline{\text { Ox.Al }}$ & $\underline{50 \times F e}$ \\
\hline Pedon ID & & & & & \\
\hline s95083005 & Oi1 & $1-0$ & & & \\
\hline (north) & Oi2 & $0-2$ & & & \\
\hline & $\mathrm{Oe}$ & $2-4$ & & & \\
\hline & A & $4-13$ & & & \\
\hline & $\mathrm{BA}$ & $13-25$ & & & \\
\hline & Bw1 & $25-46$ & & & \\
\hline & $\mathrm{Bw} 2$ & $46-79$ & & & \\
\hline & $\mathrm{C}$ & $79-97$ & & & \\
\hline s95083007 & Oi1 & $1-0$ & & & \\
\hline (south) & Oi2 & $0-3$ & & & \\
\hline & $\mathrm{Oe}$ & $3-6$ & & & \\
\hline & A & 6-18 & & & \\
\hline & $\mathrm{Bw}$ & $18-63$ & 0.83 & 0.64 & 1.055 \\
\hline & $\mathrm{BC}$ & 63-91 & & & \\
\hline s95093004 & Oi1 & $2-0$ & & & \\
\hline (north) & Oi2 & $0-3$ & & & \\
\hline & $\mathrm{Oe}$ & $3-5$ & & & \\
\hline & A & $5-15$ & & & \\
\hline & $\mathrm{Bw}$ & $15-51$ & & & \\
\hline & $\mathrm{BC}$ & $51-88$ & & & \\
\hline & $2 \mathrm{C}$ & $88-108$ & & & \\
\hline s95093005 & Oi1 & $2-0$ & & & \\
\hline (south) & Oi2 & $0-3$ & & & \\
\hline & $\mathrm{Oe}$ & $3-5$ & & & \\
\hline & A & $5-11$ & & & \\
\hline & BA & $11-24$ & & & \\
\hline & $\mathrm{Bw}$ & $24-46$ & & & \\
\hline & $\mathrm{BC}$ & $46-67$ & & & \\
\hline & $\mathrm{C}$ & $67-100$ & & & \\
\hline
\end{tabular}


Basic characterization data for Snowdog pedons.

\begin{tabular}{|c|c|c|c|c|c|c|c|c|}
\hline$\underline{\text { Pedon ID }}$ & $\underline{\text { Horizon }}$ & (cm) & $\frac{\text { Thickness }}{(\mathrm{cm})}$ & $\left(\mathrm{Mg} \mathrm{m}^{-3}\right)^{\underline{\mathrm{Db}}}$ & $\geq 2 \mathrm{~mm}$ & $\underline{\text { Clay }}$ & $\underline{\text { Silt }}$ & $\underline{\text { Sand }}$ \\
\hline \multirow[t]{12}{*}{95083001} & Oil & $2-0$ & 2 & 0.05 & 30 & na & na & na \\
\hline & Oi2 & $0-3$ & 3 & 0.07 & 40 & na & na & na \\
\hline & $\mathrm{Oa}$ & $3-9$ & 6 & 0.25 & 30 & na & na & na \\
\hline & A & $9-13$ & 4 & 0.52 & 30 & 24.4 & 40.3 & 35.3 \\
\hline & $\mathrm{AB}$ & $13-24$ & 11 & 0.72 & 30 & 23.7 & 33.5 & 42.8 \\
\hline & $\mathrm{Bw}$ & $24-42$ & 18 & 1.22 & 30 & 21.4 & 30.4 & 48.2 \\
\hline & $\mathrm{Bx} 1$ & $42-65$ & 23 & 1.83 & 30 & 15.5 & 34.8 & 49.7 \\
\hline & $\mathrm{Bx} 2$ & $65-105$ & 40 & 1.82 & 25 & 11.2 & 30.9 & 57.9 \\
\hline & $2 \mathrm{C} 1$ & $105-121$ & 16 & 1.69 & 30 & 43.8 & 36.5 & 19.7 \\
\hline & $2 \mathrm{C} 2$ & $121-148$ & 28 & 1.74 & 20 & 40.4 & 45.4 & 14.2 \\
\hline & $2 \mathrm{C} 3$ & $148-159$ & 11 & 1.75 & 25 & 45.2 & 46.2 & 8.6 \\
\hline & $2 \mathrm{C} 4$ & $159-205$ & 46 & 1.33 & 45 & 40.3 & 46.4 & 13.3 \\
\hline \multirow[t]{10}{*}{95093006} & Oi1 & $2-0$ & 2 & 0.05 & 30 & na & na & na \\
\hline & Oi2 & $0-2$ & 2 & 0.07 & 15 & na & na & na \\
\hline & Oe & $2-4$ & 2 & 0.10 & 15 & na & na & na \\
\hline & A & $4-16$ & 12 & 0.52 & 30 & 18.8 & 43.2 & 38 \\
\hline & BA & $16-24$ & 8 & 0.72 & 20 & 27.8 & 43.1 & 29.1 \\
\hline & Bw1 & $24-36$ & 12 & 1.22 & 15 & 24.1 & 41.8 & 34.1 \\
\hline & Bw2 & $36-48$ & 12 & 1.23 & 15 & 15.4 & 40.1 & 44.5 \\
\hline & $\mathrm{Bx}$ & 48-92 & 44 & 1.63 & 25 & 11.9 & 41.8 & 46.3 \\
\hline & $\mathrm{BC}$ & $92-132$ & 40 & 1.78 & 40 & 20.2 & 47.4 & 32.4 \\
\hline & $2 \mathrm{BC}$ & $132-200$ & 68 & 1.61 & 45 & 18.4 & 49.4 & 32.2 \\
\hline \multirow[t]{9}{*}{95083004} & Oil & $2-0$ & 2 & 0.05 & 30 & na & na & na \\
\hline & Oi2 & $0-4$ & 4 & 0.07 & 50 & na & na & na \\
\hline & A & $4-9$ & 5 & 0.52 & 35 & 13.5 & 38.4 & 48.1 \\
\hline & $\mathrm{AB}$ & $9-17$ & 8 & 0.72 & 30 & 26.3 & 40.1 & 33.6 \\
\hline & Bw1 & $17-43$ & 26 & 1.03 & 25 & 22.9 & 40.6 & 36.5 \\
\hline & Bw2 & $43-67$ & 24 & 1.23 & 25 & 19.3 & 38.4 & 42.3 \\
\hline & $\mathrm{Bx} 1$ & $67-85$ & 18 & 1.87 & 40 & 14.6 & 36.9 & 48.5 \\
\hline & $\mathrm{Bx} 2$ & $85-180$ & 65 & 1.85 & 40 & 14.6 & 37.3 & 48.1 \\
\hline & $\mathrm{BC}$ & $180-203$ & 20 & 1.85 & 20 & 11.9 & 36.9 & 51.2 \\
\hline \multirow[t]{9}{*}{95093008} & Oi1 & $2-0$ & 2 & 0.05 & 30 & na & na & na \\
\hline & Oi2 & $0-3$ & 3 & 0.07 & 15 & na & na & na \\
\hline & Oe & $3-6$ & 3 & 0.10 & 15 & na & na & na \\
\hline & A & $6-14$ & 8 & 0.52 & 25 & 16.4 & 48.4 & 35.2 \\
\hline & $\mathrm{A} / \mathrm{E}$ & $14-32$ & 18 & 1.41 & 35 & 23.6 & 47.1 & 29.3 \\
\hline & $\mathrm{Bw}$ & $32-55$ & 23 & 1.11 & 20 & 17.6 & 42 & 40.4 \\
\hline & $\mathrm{Bx}$ & $55-100$ & 45 & 1.60 & 30 & 13.8 & 33.1 & 53.1 \\
\hline & $\mathrm{BC}$ & $100-131$ & 31 & 1.60 & 65 & 9.8 & 39.3 & 50.9 \\
\hline & $\mathrm{C}$ & $131-165$ & 34 & 1.60 & 75 & 13.6 & 49.3 & 37.1 \\
\hline
\end{tabular}


Basic characterization data for Snowdog pedons (continued).

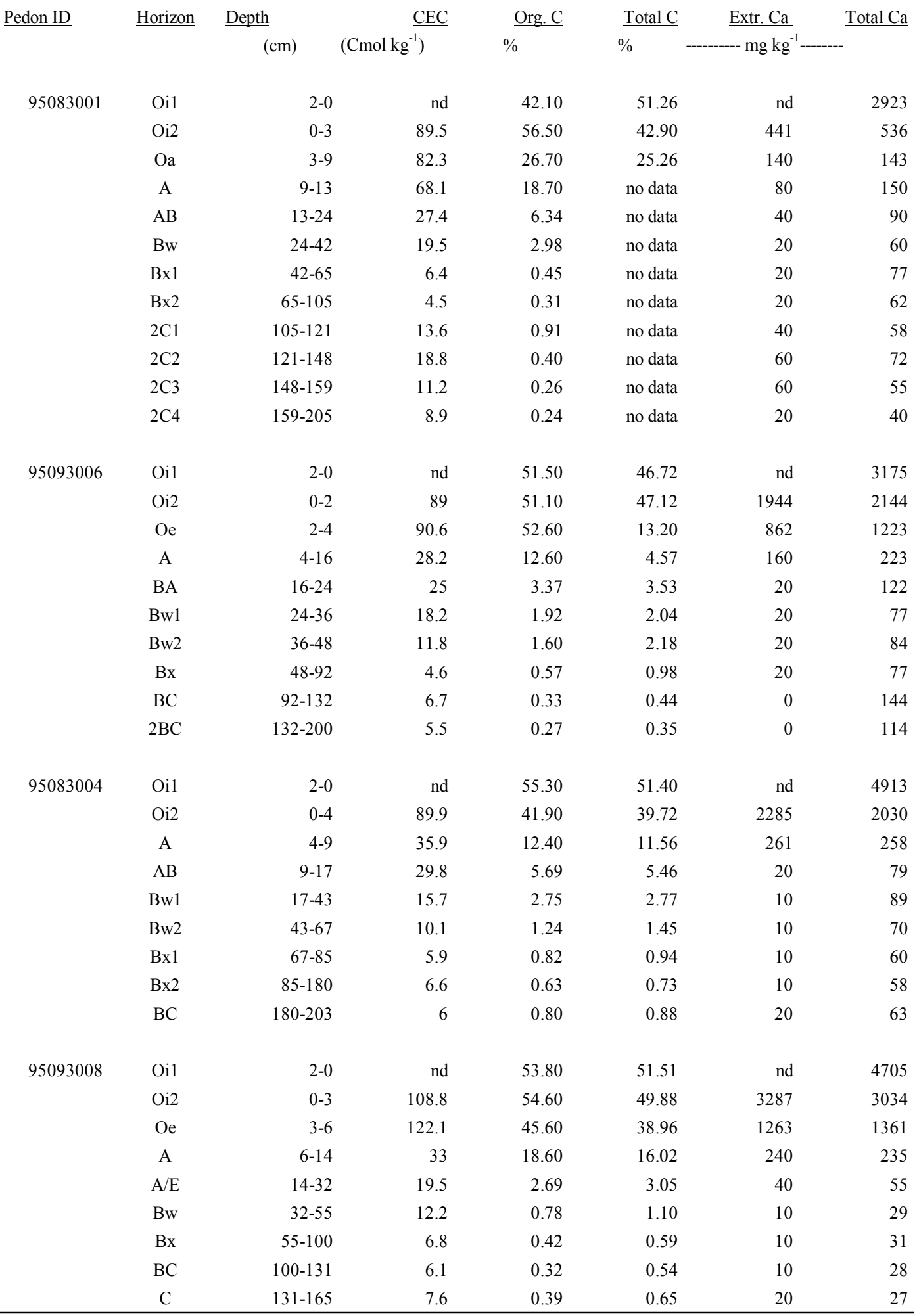


Basic characterization data for Snowdog pedons (continued).

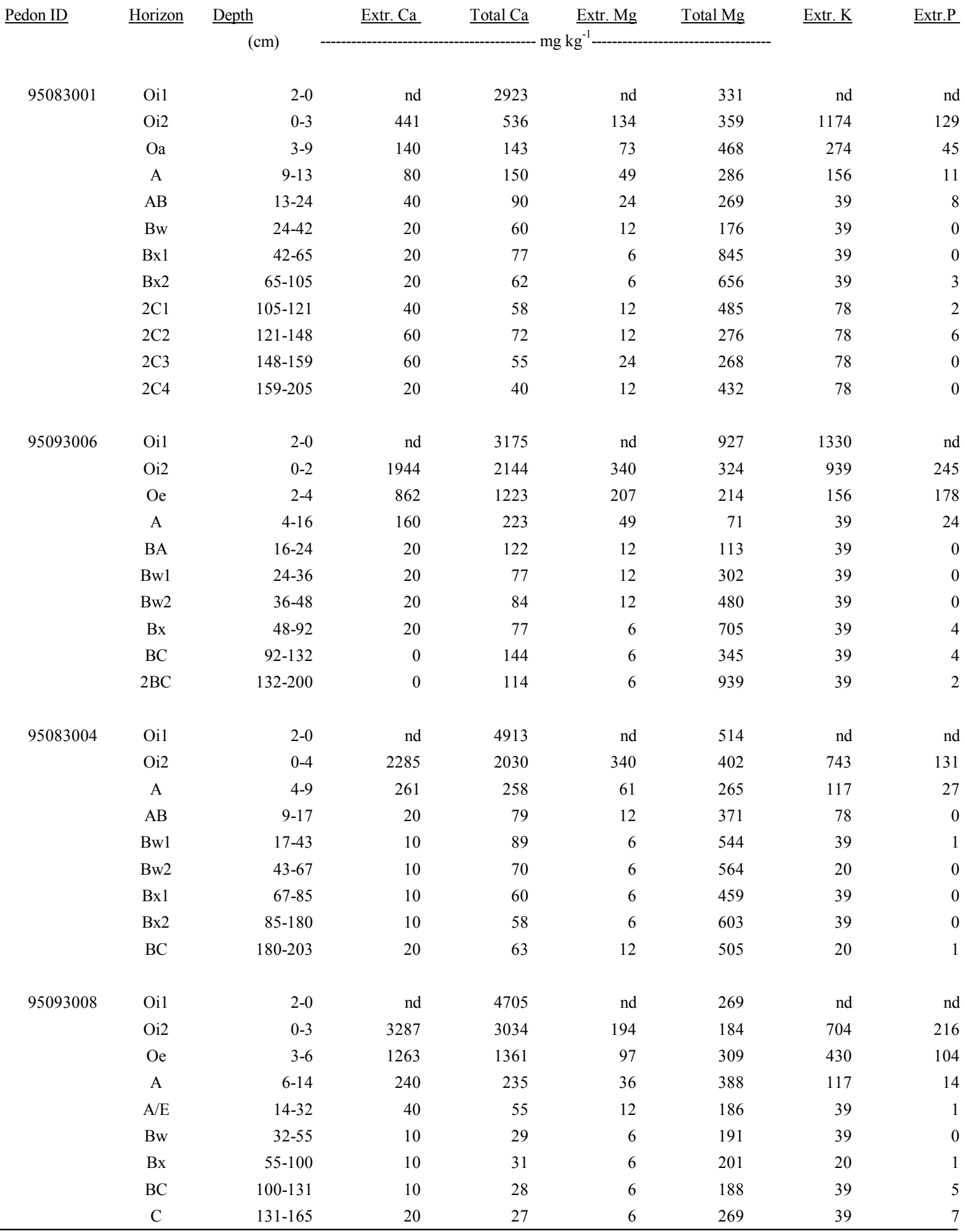


Basic characterization data for Snowdog pedons (continued).

\begin{tabular}{|c|c|c|c|c|c|c|c|}
\hline \multirow[t]{2}{*}{$\underline{\text { Pedon ID }}$} & $\underline{\text { Horizon }}$ & Depth & $\underline{\text { Total P }}$ & $\mathrm{pH}(\mathrm{H} 2 \mathrm{O})$ & ECEC & $\underline{\text { Base sat }}$ & \multirow{2}{*}{$\frac{\text { Extr.A }}{\left(\mathrm{Cmol} \mathrm{kg}^{-1}\right)}$} \\
\hline & & $(\mathrm{cm})$ & & \multicolumn{2}{|c|}{$\left(\mathrm{Cmol} \mathrm{kg}^{-1}\right)$} & $\%$ of ECEC & \\
\hline \multirow[t]{12}{*}{95083001} & Oi1 & $2-0$ & 993 & nd & nd & nd & nd \\
\hline & Oi2 & $0-3$ & 1354 & nd & 29.9 & 82.3 & 5.3 \\
\hline & $\mathrm{Oa}$ & $3-9$ & 1041 & nd & 12.1 & 17.4 & 10.0 \\
\hline & A & $9-13$ & 676 & 3.3 & 13.3 & 10.5 & 11.9 \\
\hline & $\mathrm{AB}$ & $13-24$ & 355 & 3.4 & 10.8 & 5.6 & 10.2 \\
\hline & $\mathrm{Bw}$ & $24-42$ & 209 & 3.6 & 8.5 & 4.7 & 8.1 \\
\hline & $\mathrm{Bx} 1$ & $42-65$ & 173 & 4.4 & 3.9 & 7.7 & 3.6 \\
\hline & $\mathrm{Bx} 2$ & $65-105$ & 169 & 4.6 & 2.2 & 13.6 & 1.9 \\
\hline & $2 \mathrm{C} 1$ & $105-121$ & 534 & 4.7 & 5.6 & 10.7 & 5.0 \\
\hline & $2 \mathrm{C} 2$ & $121-148$ & 300 & 4.7 & 5.5 & 12.7 & 4.8 \\
\hline & $2 \mathrm{C} 3$ & $148-159$ & 137 & 4.6 & 6.2 & 11.3 & 5.5 \\
\hline & $2 \mathrm{C} 4$ & $159-205$ & 126 & 4.5 & 5.1 & 7.8 & 4.7 \\
\hline \multirow[t]{10}{*}{95093006} & Oil & $2-0$ & 944 & nd & nd & nd & nd \\
\hline & Oi2 & $0-2$ & 902 & nd & 20.8 & 94.7 & 1.1 \\
\hline & Oe & $2-4$ & 830 & nd & 13.9 & 85.6 & 2.0 \\
\hline & A & $4-16$ & 379 & 3.3 & 8.3 & 20.5 & 6.6 \\
\hline & BA & $16-24$ & 192 & 3.7 & 14.3 & 2.8 & 13.9 \\
\hline & Bw1 & $24-36$ & 173 & 3.9 & 13.1 & 3.1 & 12.7 \\
\hline & Bw2 & $36-48$ & 159 & 4.2 & 9.2 & 4.3 & 8.8 \\
\hline & $\mathrm{Bx}$ & $48-92$ & 119 & 4.7 & 4.2 & 7.1 & 3.9 \\
\hline & $\mathrm{BC}$ & $92-132$ & 157 & 4.6 & 4.8 & 2.1 & 4.7 \\
\hline & $2 \mathrm{BC}$ & $132-200$ & 151 & 4.6 & 5.2 & 1.9 & 5.1 \\
\hline \multirow[t]{9}{*}{95083004} & Oil & $2-0$ & 761 & nd & nd & nd & nd \\
\hline & Oi2 & $0-4$ & 710 & nd & 22.1 & 92.3 & 1.7 \\
\hline & A & $4-9$ & 366 & 3.3 & 8.0 & 28.8 & 5.7 \\
\hline & $\mathrm{AB}$ & $9-17$ & 288 & 3.5 & 15.0 & 2.7 & 14.6 \\
\hline & Bw1 & $17-43$ & 220 & 4.3 & 7.9 & 2.5 & 7.8 \\
\hline & Bw2 & $43-67$ & 161 & 4.4 & 6.3 & 1.6 & 6.1 \\
\hline & $\mathrm{Bx} 1$ & $67-85$ & 141 & 4.5 & 5.0 & 4.0 & 4.8 \\
\hline & $\mathrm{Bx} 2$ & $85-180$ & 165 & 4.6 & 4.0 & 5.0 & 3.8 \\
\hline & $\mathrm{BC}$ & $180-203$ & 186 & 4.5 & 3.7 & 5.4 & 3.5 \\
\hline \multirow[t]{9}{*}{95093008} & Oil & $2-0$ & 689 & nd & nd & nd & nd \\
\hline & Oi2 & $0-3$ & 708 & nd & 24.1 & 97.9 & 0.5 \\
\hline & Oe & $3-6$ & 790 & nd & 12.3 & 96.7 & 0.4 \\
\hline & A & $6-14$ & 475 & 3.2 & 13.2 & 15.2 & 11.2 \\
\hline & $\mathrm{A} / \mathrm{E}$ & $14-32$ & 178 & 3.4 & 11.1 & 3.6 & 10.7 \\
\hline & $\mathrm{Bw}$ & $32-55$ & 56 & 4.0 & 9.0 & 2.2 & 8.8 \\
\hline & $\mathrm{Bx}$ & $55-100$ & 50 & 4.6 & 4.7 & 2.1 & 4.6 \\
\hline & $\mathrm{BC}$ & $100-131$ & 69 & 4.6 & 4.0 & 5.0 & 3.8 \\
\hline & $\mathrm{C}$ & $131-165$ & 76 & 4.5 & 4.5 & 6.7 & 4.2 \\
\hline
\end{tabular}


$\underline{\text { APPENDIX C }}$

MINERALOGY OF THE PEDONS 


\begin{tabular}{|c|c|c|c|c|c|c|c|c|c|c|c|c|c|c|c|}
\hline Appendix C. & & & & & & & & & & & & & & & \\
\hline Table & & & & & & & & & & & & & & & \\
\hline & & & & & & & & & & & & & & & \\
\hline & & & 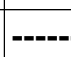 & 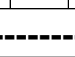 & - & $-\cdots$ & $-\cdots$ & Mine & $\mathrm{eral}^{\dagger}$ & $(\%)$ & ) ----. & 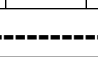 & - & ----.. & 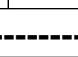 \\
\hline Series & Pedon ID & Horizonł & $\underline{\mathbf{Q Z}}$ & RA & CD. & $\underline{\mathrm{OP}}$ & MI & MS & FK & BT & $\mathrm{HN}$ & PR & ZR & AM & BY \\
\hline & & & & & & & & & & & & & & & \\
\hline Blackwater & 083008 & $E(F S)$ & 87 & 5 & 4 & 1 & 3 & & & & & & & & \\
\hline Blackwater & 093001 & $\mathrm{Bw}(\mathrm{FS})$ & 99 & & & & & & & & & & & & \\
\hline & & & & & & & & & & & & & & & \\
\hline Gauley & 075001 & $\mathrm{Bh} / \mathrm{Bs}(\mathrm{FS})$ & 56 & 43 & 1 & & & & & & & & & & \\
\hline Gauley & 075002 & Bs (FS) & 91 & 5 & 3 & & & 1 & & & & & & & \\
\hline Gauley & 083003 & Bhs (FS) & 60 & 39 & 1 & & & & & & & & & & \\
\hline Gauley & 093007 & Bh/Bhs (FS) & 61 & 37 & 2 & & & & & & & & & & \\
\hline & & & & & & & & & & & & & & & \\
\hline MWD Gauley & 083002 & $\mathrm{Bh} / \mathrm{Bs}(\mathrm{FS})$ & 88 & 11 & 1 & & & & & & & & & & \\
\hline MWD Gauley & 083006 & $\mathrm{Bh}(\mathrm{FS})$ & 83 & 10 & 5 & & 1 & & & & & & & & \\
\hline MWD Gauley & 093002 & $\mathrm{Bh}(\mathrm{FS})$ & 98 & & 2 & & & & & & & & & & \\
\hline MWD Gauley & 093003 & $\mathrm{Bh}(\mathrm{FS})$ & 98 & 2 & & & & & & & & & & & \\
\hline & & & & & & & & & & & & & & & \\
\hline Mandy & 083005 & Bw2 (CSi) & 60 & 13 & & & 21 & & 1 & 3 & 1 & & & & \\
\hline Mandy & 083007 & Bw (FS) & 77 & 21 & 2 & & & & & & & & & & \\
\hline Mandy & 093004 & $\mathrm{Bw}$ (CSi) & 42 & 42 & & & 11 & & 1 & 2 & & 1 & & & \\
\hline Mandy & 093005 & Bw (CSi) & 66 & 17 & & & 13 & & 3 & 1 & 1 & & & & \\
\hline & & & & & & & & & & & & & & & \\
\hline Snowdog & 083001 & $\mathrm{Bw}(\mathrm{FS})$ & 61 & 37 & & 1 & & 1 & & & & & & & \\
\hline Snowdog & 083004 & Bw1 (CSi) & 61 & 27 & 2 & 1 & 6 & & 1 & & & 1 & 1 & & \\
\hline Snowdog & 093006 & Bw2 (CSi) & 57 & 28 & 1 & & 11 & & & 1 & 1 & & & 1 & 1 \\
\hline Snowdog & 093008 & Bw (Csi) & 62 & 12 & 1 & & 22 & & 2 & 1 & & & & & \\
\hline$\dagger^{\dagger}$ Mineral le & & & & & & & & & & & & & & & \\
\hline Mineral lege & is given & Table 3. & & & & & & $\mathrm{Si}=$ & coars & & 50 & & & & \\
\hline & & & & & & & & & & & & & & & \\
\hline
\end{tabular}




\begin{tabular}{|c|c|c|c|c|c|c|c|c|c|c|c|c|c|c|c|c|c|c|c|c|c|c|c|c|}
\hline & & & & & & & & & & & & & \multicolumn{12}{|c|}{ Table 2. Grain count results for the pedons: trace constituents. } \\
\hline \multirow[b]{3}{*}{ Series } & \multirow[b]{3}{*}{ Pedon ID } & \multirow[b]{3}{*}{ Horizont } & \multirow{3}{*}{\multicolumn{7}{|c|}{\begin{tabular}{ll|l|l|l|l|} 
AM & BT & BY & CL & CT & EP \\
\end{tabular}}} & & & & & & & & & & & & & & & \\
\hline & & & & & & & & & & \multirow{2}{*}{ FE } & \multirow{2}{*}{ FK } & \multirow{2}{*}{ GN } & \multirow{2}{*}{$\begin{array}{l}\text { Mine } \\
\underline{\mathrm{HN}} \\
\end{array}$} & \multirow{2}{*}{$\begin{array}{l}\text { eral } \\
\text { MI }\end{array}$} & \multirow{2}{*}{ MS } & \multirow[b]{2}{*}{$\underline{\text { OP }}$} & \multirow[b]{2}{*}{$\underline{\text { PO }}$} & \multirow{2}{*}{ PR } & \multirow{2}{*}{$\underline{Q Z}$} & \multirow{2}{*}{ RA } & \multirow{2}{*}{\multicolumn{4}{|c|}{$\underline{\mathrm{RU}} \underline{\mathrm{TM}} \underline{\underline{Z E}} \underline{\mathrm{ZF}}$}} \\
\hline & & & & & & & & & & & & & & & & & & & & & & & & \\
\hline & & & & & & & & & & & & & & & & & & & & & & & & \\
\hline Blackwater & 083008 & $E(F S)$ & & & & & $\mathrm{X}$ & & & & & & & & & & & & & & & $\mathrm{X}$ & & $\mathrm{X}$ \\
\hline Blackwater & 093001 & Bw (FS) & & $\mathrm{X}$ & & & & & & & & & $\mathrm{X}$ & & & $\mathrm{X}$ & & & & $\mathrm{X}$ & & $\mathrm{X}$ & & $\mathrm{X}$ \\
\hline & & & & & & & & & & & & & & & & & & & & & & & & \\
\hline Gauley & 075001 & $\mathrm{Bh} / \mathrm{Bs}(\mathrm{FS})$ & & & & & & & & & & & & & & & & & & & & $\mathrm{X}$ & & $x$ \\
\hline Gauley & 075002 & Bs (FS) & & & & & & & & & $X$ & & & & & & & & & & & $\mathrm{X}$ & & \\
\hline Gauley & 083003 & Bhs (FS) & & & & & & & & & & & & & $X$ & $x$ & & & & & & & & $\mathrm{X}$ \\
\hline Gauley & 093007 & Bh/Bhs (FS) & & & & & & & & & & & & & $\mathrm{X}$ & & & & & & & & & \\
\hline & & & & & & & & & & & & & & & & & & & & & & & & \\
\hline MWD Gauley & 083002 & $\mathrm{Bh} / \mathrm{Bs}(\mathrm{FS})$ & & & & & & & & & & & & & & & & & & & & & & $\mathrm{X}$ \\
\hline MWD Gauley & 083006 & $\mathrm{Bh}(\mathrm{FS})$ & & & & & & & & & & & & $\mathrm{X}$ & & $\mathrm{X}$ & & & & & & & & \\
\hline MWD Gauley & 093002 & $\mathrm{Bh}(\mathrm{FS})$ & $\mathrm{X}$ & & & & & & & $\mathrm{X}$ & & & & & & $\mathrm{X}$ & & & & $\mathrm{X}$ & & & & $\mathrm{X}$ \\
\hline MWD Gauley & 093003 & $\mathrm{Bh}(\mathrm{FS})$ & & & & & & & & & & & & & & $x$ & & $X$ & & & & & & $x$ \\
\hline & & & & & & & & & & & & & & & & & & & & & & & & \\
\hline Mandy & 083005 & Bw2 (CSi) & $X$ & & $\mathrm{X}$ & & $\mathrm{X}$ & & & $X$ & & & & & & $X$ & & $X$ & & & & $X$ & & $\mathrm{X}$ \\
\hline Mandy & 083007 & Bw (FS) & & & & & & & & & & & & & & & & & & & & & & \\
\hline Mandy & 093004 & $\mathrm{Bw}(\mathrm{CSi})$ & & & $X$ & $X$ & & & & & & & $\mathrm{X}$ & & & $X$ & $\mathrm{X}$ & & & & $X$ & $X$ & $X$ & $\mathrm{X}$ \\
\hline Mandy & 093005 & Bw (CSi) & $X$ & & $X$ & $\mathrm{X}$ & $\mathrm{X}$ & & & & & & & & & $X$ & $\mathrm{X}$ & $\mathrm{X}$ & & & $X$ & $X$ & & $\mathrm{X}$ \\
\hline & & & & & & & & & & & & & & & & & & & & & & & & \\
\hline Snowdog & 083001 & $\mathrm{Bw}(\mathrm{FS})$ & & & & & & & & & & & & & & & & & & & & & & $X$ \\
\hline Snowdog & 083004 & Bw1 (CSi) & $X$ & $X$ & & & & & $X$ & & & $X$ & & & & & $X$ & & & & & & & \\
\hline Snowdog & 093006 & Bw2 (CSi) & & & & & $X$ & & $X$ & & $X$ & & & & & & $X$ & $X$ & & & $X$ & & & $X$ \\
\hline Snowdog & 093008 & Bw (Csi) & $X$ & & $X$ & & & $X$ & & & & & $X$ & & & $\mathrm{X}$ & & $X$ & & & $X$ & & & $\mathrm{X}$ \\
\hline & & & & & & & & & & & & & & & & & & & & & & & & \\
\hline${ }^{\dagger}$ Mineral lege & nd is given & in Table 3. & & & & & & & & & & & & & & & & & & & & & & \\
\hline$\mp$ The particle & size fractior & $n$ examined is & give & $\mathrm{n}$ in & oar & the & sis; & $\mathrm{CSi}=$ & $=\mathrm{co}$ & oa & e silt & t, & $s^{\prime} \mathrm{tl}$ & sa & ad. & & & & & & & & & \\
\hline
\end{tabular}


Table 3. Legend of mineral names used for the pedons.

\begin{tabular}{cl} 
Symbol & Mineral \\
\hline AM & amphibole \\
BT & biotite \\
BY & beryl \\
CD & chalcedony \\
CL & chlorite \\
CT & cassiterite \\
EP & epidote \\
FE & iron oxides \\
FK & potassium feldspar \\
GN & garnet \\
HN & hornblende \\
MI & mica \\
MS & muscovite \\
OP & opaques \\
PO & plant opal \\
PR & pyroxene \\
QZ & quartz \\
RA & resistant aggregates \\
RU & rutile \\
TM & tourmaline \\
ZE & zeolite \\
ZR & zircon \\
\hline
\end{tabular}




\section{APPENDIX D}

VEGETATIVE BIOMASS DATA FOR THE SERIES 
Table 1a. Biomass data for the Blackwater sites.

\begin{tabular}{|c|c|c|c|c|c|c|c|c|c|}
\hline$\underline{\text { Pedon ID }}$ & $\geq 12.5$ & $>12.5$ dead & $\underline{2.5-12.5}$ & $.25-2.5$ & $\frac{\text { Seedlings }}{-2}$ & $\underline{\text { Shrubs }}$ & $\underline{\text { Herbs }}$ & $\underline{D W D}$ & $\underline{\text { Total }}$ \\
\hline 083008 & 11.30 & 0.21 & 1.20 & 0.00 & 0.00 & 0.08 & 0.00 & 0.18 & 12.97 \\
\hline 093001 & 17.13 & 0.61 & 0.86 & 0.03 & 0.00 & 0.06 & 0.03 & 0.03 & 18.75 \\
\hline ave & 11.30 & 0.21 & 1.20 & 0.00 & 0.00 & 0.08 & 0.00 & 0.18 & 12.97 \\
\hline std dev & 4.13 & 0.28 & 0.24 & 0.02 & 0.00 & 0.01 & 0.02 & 0.11 & 4.09 \\
\hline CV & 0.37 & 1.36 & 0.20 & & & 0.16 & & 0.61 & 0.32 \\
\hline
\end{tabular}

Table 1b. Sawtimber species biomass

\begin{tabular}{|c|c|c|c|}
\hline \multirow[b]{2}{*}{$\underline{\text { Species }}$} & ---------Si & - & \multirow[b]{2}{*}{ Average } \\
\hline & $\underline{083008}$ & $\frac{093001}{m^{-2}}$ & \\
\hline Hemlock & 0.00 & 8.26 & 8.26 \\
\hline Y.birch & 3.95 & 0.00 & 3.95 \\
\hline R.maple & 1.97 & 7.44 & 9.40 \\
\hline R.spruce & 5.39 & 1.44 & 6.83 \\
\hline
\end{tabular}


Table 2a. Biomass data for the Gauley sites.

\begin{tabular}{|c|c|c|c|c|c|c|c|c|c|}
\hline Pedon ID & $\geq 12.5$ & $>12.5$ dead & 2.5-12.5 & $.25-2.5$ & $\frac{\text { Seedlings }}{\mathrm{m}^{-2}}$ & $\underline{\text { Shrubs }}$ & Herbs & $\underline{D W D}$ & Total \\
\hline 95075001 & 25.06 & 0.77 & 1.24 & 0.00 & 0.05 & 0.00 & 0.36 & 0.07 & 27.55 \\
\hline 95075002 & 22.41 & 2.38 & 2.42 & 4.14 & 0.45 & 0.00 & 0.16 & 0.13 & 32.08 \\
\hline 95093007 & 17.53 & 4.16 & 3.53 & 0.35 & 0.07 & 0.01 & 0.13 & 1.35 & 27.13 \\
\hline 95083003 & 23.16 & 0.34 & 1.61 & 0.08 & 0.03 & 0.06 & 0.06 & 0.16 & 25.48 \\
\hline ave & 22.04 & 1.91 & 2.20 & 1.14 & 0.15 & 0.02 & 0.18 & 0.43 & 28.06 \\
\hline std dev & 3.21 & 1.74 & 1.01 & 2.00 & 0.20 & 0.03 & 0.13 & 0.62 & 2.82 \\
\hline $\mathrm{CV}$ & 0.15 & 0.91 & 0.46 & 1.76 & 1.35 & 1.53 & 0.74 & 1.45 & 0.10 \\
\hline
\end{tabular}

Table 2b. Sawtimber species biomass for the Gauley sites.

\begin{tabular}{|c|c|c|c|c|c|}
\hline Species & $\underline{075001}$ & $\underline{075002}$ & 093007 & 083003 & Average \\
\hline Red spruce & 2308 & 2241 & 1620 & 1868 & 2009 \\
\hline Yellow birch & 1.98 & 0.00 & 1.33 & 0.23 & 0.89 \\
\hline Red maple & 0.00 & 0.00 & 0.00 & 4.24 & 1.06 \\
\hline
\end{tabular}


Table 3a. Biomass data for the MWD Gauley sites.

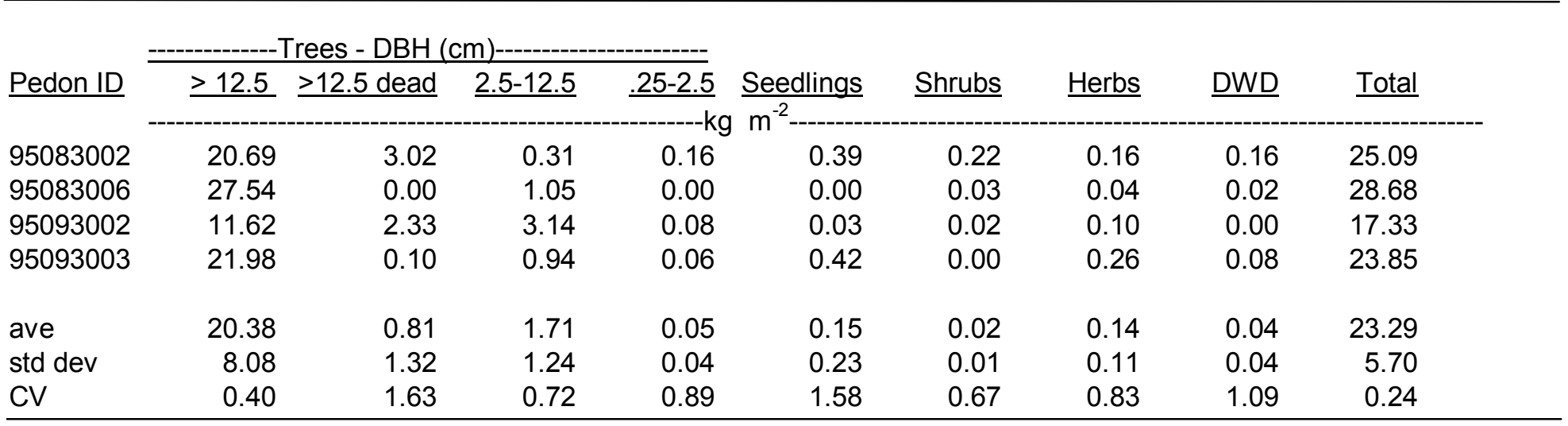

Table 3b. Sawtimber species biomass for the MWD Gauley sites.

\begin{tabular}{lrrrrr}
\hline & & & & \\
Species & $\underline{083002}$ & $\underline{083006}$ & $\underline{093002}$ & $\underline{093003}$ & Average \\
Red spruce & -18.21 & 22.74 & 5.74 & 20.84 & 16.88 \\
Canadian hemlock & 1.27 & 2.89 & 2.23 & 0.00 & 1.60 \\
Red maple & 0.00 & 1.91 & 3.65 & 1.14 & 1.67 \\
Yellow birch & 1.21 & 0.00 & 0.00 & 0.00 & 0.30 \\
\hline
\end{tabular}


Table 4a. Biomass data for the Mandy sites.

\begin{tabular}{|c|c|c|c|c|c|c|c|c|c|}
\hline \multirow[b]{2}{*}{$\underline{\text { Pedon ID }}$} & & $125 d$ & & & \multirow[b]{2}{*}{$\frac{\text { Seedlings }}{\mathrm{m}^{-2}}$} & \multirow[b]{2}{*}{$\underline{\text { Shrubs }}$} & \multirow[b]{2}{*}{$\underline{\text { Herbs }}$} & \multirow[b]{2}{*}{$\underline{D W D}$} & \multirow[b]{2}{*}{$\underline{\text { Total }}$} \\
\hline & $\geq 12.5$ & $\geq 12.5$ dead & $2.5-12.5$ & $\frac{.25-2.5}{--\mathrm{kg}}$ & & & & & \\
\hline 95083005 & 24.76 & 2.82 & 2.34 & 0.08 & 0.01 & 0.04 & 0.10 & 0.26 & 30.41 \\
\hline 95083007 & 29.94 & 0.68 & 1.36 & 0.10 & 0.00 & 0.00 & 0.11 & 0.08 & 32.27 \\
\hline 95093004 & 26.73 & 4.55 & 4.52 & 0.20 & 0.04 & 0.00 & 0.03 & 0.16 & 36.23 \\
\hline 95093005 & 17.26 & 0.34 & 2.45 & 0.03 & 0.00 & 0.00 & 0.06 & 0.09 & 20.23 \\
\hline ave & 24.67 & 2.10 & 2.67 & 0.10 & 0.01 & 0.01 & 0.08 & 0.15 & 29.78 \\
\hline std dev & 5.38 & 1.97 & 1.33 & 0.07 & 0.02 & 0.02 & 0.04 & 0.08 & 6.82 \\
\hline CV & 0.22 & 0.94 & 0.50 & 0.70 & 1.64 & 1.82 & 0.46 & 0.57 & 0.23 \\
\hline
\end{tabular}

Table 4b. Sawtimber species biomass for the Mandy sites.

\begin{tabular}{|c|c|c|c|c|c|}
\hline$\underline{\text { Species }}$ & $\underline{083005}$ & $\underline{083007}$ & $\underline{093004}$ & $\underline{093005}$ & Average \\
\hline Yellow Birch & 0.00 & 1.85 & 20.71 & 8.36 & 7.73 \\
\hline American Beech & 5.18 & 0.40 & 2.11 & 0.00 & 1.92 \\
\hline Red maple & 0.00 & 1.59 & 0.00 & 3.18 & 1.19 \\
\hline Black cherry & 0.00 & 10.38 & 0.00 & 5.71 & 4.02 \\
\hline Red spruce & 0.00 & 5.26 & 3.45 & 0.00 & 2.18 \\
\hline Serviceberry & 0.00 & 0.08 & 0.34 & 0.00 & 0.10 \\
\hline Canadian hemlock & 0.00 & 2.91 & 0.00 & 0.00 & 0.73 \\
\hline Sweet Birch & 19.58 & 0.00 & 0.00 & 0.00 & 4.90 \\
\hline Striped maple & 0.00 & 0.00 & 0.13 & 0.00 & 0.03 \\
\hline Red oak & 0.00 & 7.46 & 0.00 & 0.00 & 1.86 \\
\hline
\end{tabular}


Table 5a. Biomass for the Snowdog sites.

\begin{tabular}{|c|c|c|c|c|c|c|c|c|c|}
\hline Pedon ID & $\geq 12.5$ & $\geq 12.5$ dead & $2.5-12.5$ & $\frac{.25-2.5}{.----k g}$ & 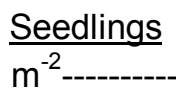 & Shrubs & Herbs & DWD & Total \\
\hline 95083001 & 24.33 & 0.31 & 0.08 & 0.00 & 0.01 & 0.00 & 0.08 & 0.09 & 24.90 \\
\hline 95083004 & 28.03 & 1.44 & 2.29 & 0.00 & 0.00 & 0.00 & 0.05 & 0.28 & 32.10 \\
\hline 95093006 & 17.40 & 2.84 & 2.83 & 0.08 & 0.00 & 0.00 & 0.08 & 0.09 & 23.32 \\
\hline 95093008 & 34.24 & 0.00 & 0.13 & 0.03 & 0.00 & 0.00 & 0.03 & 0.14 & 34.57 \\
\hline ave & 26.00 & 1.15 & 1.33 & 0.03 & 0.00 & 0.00 & 0.06 & 0.15 & 28.72 \\
\hline std dev & 7.04 & 1.29 & 1.43 & 0.04 & 0.00 & 0.00 & 0.02 & 0.09 & 5.46 \\
\hline $\mathrm{CV}$ & 0.27 & 1.12 & 1.07 & 1.33 & 1.37 & & 0.39 & 0.59 & 0.19 \\
\hline
\end{tabular}

Table 5b. Sawtimber species biomass for the Snowdog sites.

\begin{tabular}{|c|c|c|c|c|c|}
\hline & $\underline{083001}$ & $\underline{083004}$ & $\underline{093006}$ & $\underline{093008}$ & Average \\
\hline & & & $---k g ~ m$ & & \\
\hline Yellow birch & 4.30 & 0.71 & 16.10 & 4.64 & 6.44 \\
\hline Red maple & 1.10 & 2.04 & 0.67 & 22.12 & 6.48 \\
\hline Black cherry & 3.33 & 9.19 & 0.00 & 3.96 & 4.12 \\
\hline Canadian hemlock & 4.31 & 0.00 & 0.00 & 3.51 & 1.96 \\
\hline Beech & 1.31 & 0.00 & 0.00 & 0.00 & 0.33 \\
\hline Cucumber magnolia & 8.46 & 0.00 & 0.00 & 0.00 & 2.11 \\
\hline Red spruce & 1.52 & 0.00 & 0.00 & 0.00 & 0.38 \\
\hline Serviceberry & 0.00 & 0.00 & 0.62 & 0.00 & 0.16 \\
\hline Sugar maple & 0.00 & 2.47 & 0.00 & 0.00 & 0.62 \\
\hline Red oak & 0.00 & 13.63 & 0.00 & 0.00 & 3.41 \\
\hline
\end{tabular}


Table 6. Weighted average densities used for dead woody debris (decay class 1) at each site.

\begin{tabular}{cc} 
& Density $\left(\mathrm{g} \mathrm{cm}^{-3}\right)$ \\
075001 & 0.41 \\
075002 & 0.431 \\
& \\
083001 & 0.459 \\
083002 & 0.43 \\
083003 & 0.452 \\
083004 & 0.562 \\
083005 & 0.65 \\
083006 & 0.424 \\
083007 & 0.527 \\
083008 & 0.547 \\
093001 & \\
093002 & 0.452 \\
093003 & 0.469 \\
093004 & 0.415 \\
093005 & 0.57 \\
093006 & 0.588 \\
093007 & 0.62 \\
093008 & 0.586 \\
\hline
\end{tabular}


APPENDIX E

SOIL MICROBIAL BIOMASS DATA FOR THE GAULEY AND

MANDY SERIES 
Appendix E. Total soil and soil microbial biomass carbon for selected horizons of the Gauley and Mandy series.

\begin{tabular}{|c|c|c|c|c|c|c|c|c|c|}
\hline PedonID & Horizon & TOC (\%) & $\underline{\operatorname{SMBC}(\%)}$ & $\underline{\mathrm{SMBC} / \mathrm{TOC}}$ & PedonID & $\underline{\text { Horizon }}$ & $\operatorname{TOC}(\%)$ & $\underline{\operatorname{SMBC}(\%)}$ & $\underline{\mathrm{SMBC} / \mathrm{TOC}}$ \\
\hline 83003 & Oe & 55.7 & 20.17 & 0.36 & 83003 & $\mathrm{AE}$ & 2.42 & 0.82 & 0.34 \\
\hline 83003 & $\mathrm{Oe}$ & 55.7 & 22.84 & 0.41 & 83003 & $\mathrm{AE}$ & 2.42 & 0.36 & 0.15 \\
\hline \multirow[t]{3}{*}{83003} & $\mathrm{Oe}$ & 55.7 & 10.18 & 0.18 & 83003 & $\mathrm{AE}$ & 2.42 & 0.57 & 0.24 \\
\hline & & mean $=$ & 17.73 & 0.32 & & & mean= & 0.58 & 0.24 \\
\hline & Standarc & Deviation $=$ & 6.67 & & & \multicolumn{2}{|c|}{ Standard Deviation = } & 0.23 & \\
\hline 93007 & Oe & 55.2 & 11.82 & 0.21 & 93007 & $\mathrm{AE}$ & 11.6 & 0.85 & 0.07 \\
\hline 93007 & $\mathrm{Oe}$ & 55.2 & 12.11 & 0.22 & 93007 & $A E$ & 11.6 & 2.86 & 0.25 \\
\hline \multirow[t]{3}{*}{93007} & $\mathrm{Oe}$ & 55.2 & 4.15 & 0.08 & 93007 & $\mathrm{AE}$ & 11.6 & 0.61 & 0.05 \\
\hline & & mean $=$ & 9.36 & 0.17 & & & mean= & 1.44 & 0.12 \\
\hline & Standarc & Deviation = & 4.51 & & & \multicolumn{2}{|c|}{ Standard Deviation = } & 1.23 & \\
\hline 93004 & $\mathrm{Oe}$ & 50.5 & 36.12 & 0.72 & 93004 & A & 19.5 & 0.99 & 0.05 \\
\hline 93004 & $\mathrm{Oe}$ & 50.5 & 42.29 & 0.84 & 93004 & A & 19.5 & 0.63 & 0.03 \\
\hline \multirow[t]{3}{*}{93004} & $\mathrm{Oe}$ & 50.5 & 20.61 & 0.41 & 93004 & A & 19.5 & 1.81 & 0.09 \\
\hline & & mean $=$ & 33.01 & 0.65 & & & mean $=$ & 1.14 & 0.06 \\
\hline & Standarc & Deviation = & 11.17 & & & Standarc & Deviation = & 0.61 & \\
\hline 93005 & $\mathrm{Oe}$ & 43.2 & 10.37 & 0.24 & 93005 & A & 11.6 & 0.86 & 0.07 \\
\hline 93005 & $\mathrm{Oe}$ & 43.2 & 15.94 & 0.37 & 93005 & A & 11.6 & 0.27 & 0.02 \\
\hline \multirow[t]{3}{*}{93005} & $\mathrm{Oe}$ & 43.2 & 13.69 & 0.32 & 93005 & A & 11.6 & 0.29 & 0.03 \\
\hline & & mean $=$ & 13.34 & 0.31 & & & mean= & 0.47 & 0.04 \\
\hline & Standarc & Deviation = & 2.80 & & & Standarc & Deviation = & 0.34 & \\
\hline
\end{tabular}


APPENDIX F

RELATIVE ELEVATION EXCAVATION FRAMEAND REGRESSION-BASED ESTIMATES OF BULK DENSITY FOR

THE SERIES 
Table 1. Frame- and regression-based bulk densities for the frigid series.

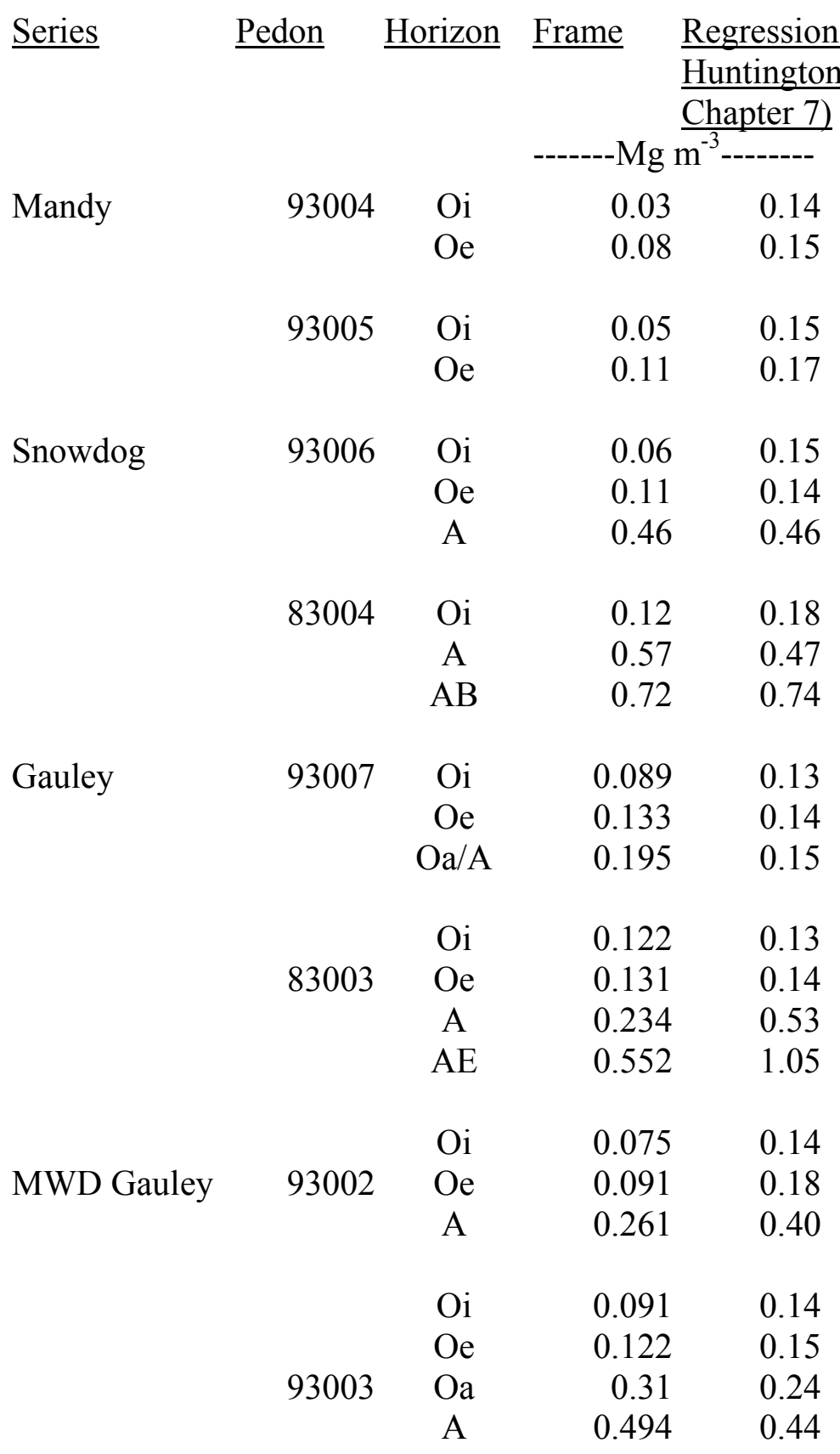


Table 2. Clod- and regression-based bulk densities for A horizons of the frigid pedons.

\begin{tabular}{|c|c|c|c|c|}
\hline$\underline{\text { Series }}$ & $\underline{\text { Pedon }}$ & Horizon & $\underline{\text { Clod-Db }}$ & $\underline{\text { Regression-Db }}$ \\
\hline \multirow{5}{*}{ Mandy } & & & & \\
\hline & 93004 & A & 1.09 & 0.34 \\
\hline & 93005 & A & 1.25 & 0.49 \\
\hline & 83007 & A & 0.82 & 0.53 \\
\hline & 83005 & A & 1.12 & 0.49 \\
\hline \multirow[t]{2}{*}{ Snowdog } & 93008 & A & 1.41 & 1.01 \\
\hline & \multicolumn{2}{|c|}{ Average $=$} & 1.14 & 0.57 \\
\hline
\end{tabular}




\section{Vitae}

The author was born 6 January, 1964 in Cincinnati, Ohio, later moving to Lake City, Tennessee. There I graduated from Clinton High School in Clinton, Tennessee during the spring of 1982. Immediately thereafter, I began attending the University of Tennessee at Knoxville, earning a Bachelor of Science in Agriculture, majoring in Plant and Soil Science, in December of 1986. In September of 1987 I moved to West Virginia and practiced Soil Science in the service of the United States Department of Agriculture, Soil Conservation Service and Natural Resources Conservation Service, primarily by working on soil surveys. I remain so employed as of the date of submission of this thesis. 